$$
\begin{aligned}
& \text { UNIVERSIDADE DE SÃO PAULO } \\
& \text { INSTITUTO DE GEOCIÊNCIAS }
\end{aligned}
$$

\title{
O REGISTRO CLIMÁTICO E AMBIENTAL DAS CONCHAS DE SAMBAQUIS E DEPÓSITOS PALEOLAGUNARES NA COSTA CENTRO-SUL CATARINENSE
}

\section{RAFAEL CASATI}

Tese apresentada ao Programa Geoquímica e Geotectônica para a obtenção do título de Doutor em Ciências

Área de concentração:
Geotectônica

Orientador: Prof. Dr. Paulo César Fonseca Giannini 
Autorizo a reprodução e divulgação total ou parcial deste trabalho, por qualquer meio convencional ou eletrônico, para fins de estudo e pesquisa, desde que citada a fonte.

Serviço de Biblioteca e Documentação do IGc/USP

Ficha catalográfica gerada automaticamente com dados fornecidos pelo(a) autor(a) via programa desenvolvido pela Seção Técnica de Informática do ICMC/USP

Bibliotecários responsáveis pela estrutura de catalogação da publicação: Sonia Regina Yole Guerra - CRB-8/4208 | Anderson de Santana - CRB-8/6658

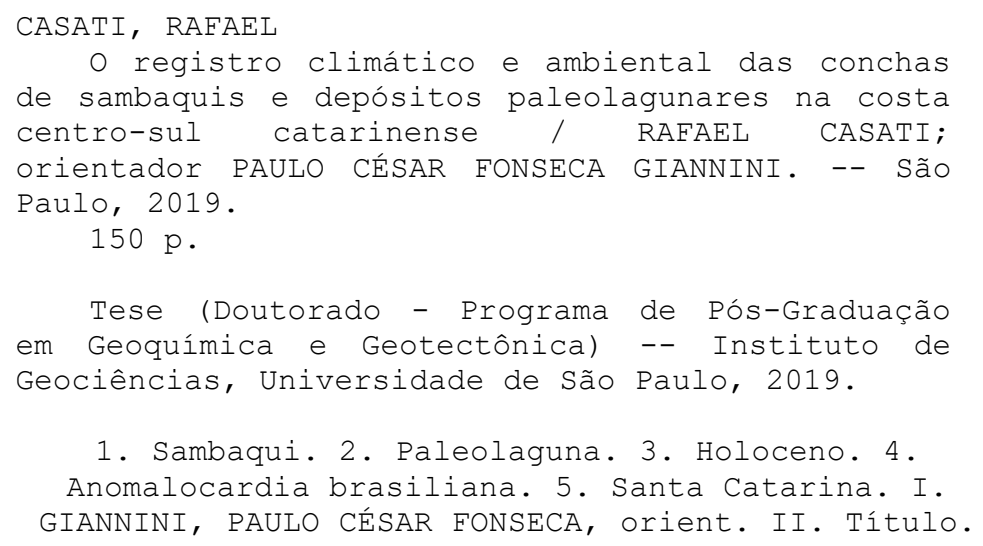




$$
\begin{aligned}
& \text { UNIVERSIDADE DE SÃO PAULO } \\
& \text { INSTITUTO DE GEOCIÊNCIAS }
\end{aligned}
$$

\section{O REGISTRO CLIMÁTICO E AMBIENTAL DAS CONCHAS DE SAMBAQUIS E DEPÓSITOS PALEOLAGUNARES NA COSTA CENTRO-SUL CATARINENSE}

\section{RAFAEL CASATI}

Orientador: Prof. Dr. Paulo César Fonseca Giannini

Tese de Doutorado

№ 603

COMISSÃO JULGADORA

Dr. Paulo César Fonseca Giannini

Dr. Marcello Guimarães Simões

Dr. Christian Millo

Dra. Ximena Suarez Villagran

Dr. Paulo Antônio Dantas de Blasis

Dra. Milene Fornari

SÃO PAULO

2019 



\section{AGRADECIMENTOS}

Agradeço il mio Maestro, Prof. Paulo César Giannini, primeiramente pelo convite, um ano antes do início formal dessa pesquisa, para visitar os gigantescos sambaquis de Santa Catarina, verdadeiras "caixas-fortes do Tio Patinhas", tanto pela impressionante sensação de se estar sobre as moedas de ouro do personagem avarento de Carl Barks - tamanha a quantidade de conchas que compõe esse tipo de sítio arqueológico - quanto pelo verdadeiro tesouro que eles contêm; também, pelo privilégio de tê-lo tido como orientador durante o doutorado; por sua paciência e didática ímpares; pela amizade e exemplo.

À Prof. Ximena Villagran (MAE-USP), pelo apoio e incentivo à pesquisa com os sambaquis, por suas aulas e por ter composto a banca da minha qualificação.

Ao Prof. Francisco William Cruz (IGc-USP), pela colaboração com a pesquisa dos isótopos estáveis nos laboratórios de sistemas cársticos (LASCA) e de isótopos estáveis (LES), onde contei com a ajuda da química Alyne Barros e da bióloga Gisele Utida; obrigado, meninas!

Aos professores do IO-USP, Rubens Figueira, pela colaboração com a pesquisa dos alcalinos terrosos no Laboratório de Química Inorgânica Marinha (LAQIMAR) e, Christian Millo, por suas aulas e, também, por ter composto a banca da minha qualificação.

Ao apoio franco-ítalo-brasileiro de Matthieu Carré (Université Montpellier 2) e André Carlo Colonese (University of York), na elaboração do método para as análises isotópicas e pelas discussões.

Ao geólogo Vinícius Ribau Mendes, por me apresentar a "Escola Volpato de redação científica"; o Prof. Gilson Volpato, com suas palestras e livros, foram fonte de grande inspiração para a elaboração dessa tese e assim, agradeço igualmente ao Prof. Volpato.

À geóloga Fernanda Rodrigues, pela ajuda com a coleta em campo. 
Aos malacólogos, Luiz Ricardo Simone (MZUSP) e Rodrigo César Marques (UFVJM), com a ajuda na identificação taxonômica e ecológica dos moluscos aqui estudados.

Aos amigos do atemporal "Mocó" (a mítica e barulhenta sala 3 do Bloco C do IGc-USP) e adjacências, Muro, Banana, Mindy, Dri, Valentina, Janine, Luciana, Thays, Pirula, Portuga, Wolverine, Flávio, Lenhare, Penéllope, Zuleta e, em especial, Lucas, Fran e Guga, o trio com quem dividi este antro de saber e baboseiras pelos últimos quatro anos e que tem participação direta na análise e discussão desse trabalho.

Ao entusiasta Paulo Boer, pelo apoio com a coleta de dados tafonômicos.

Aos técnicos do IGc-USP, Elaine (Sedimentologia), Verônica (impregnação), Paulinho e Renato (laminação), Isaac (MEV).

À minha linda namorada Pri, e sua família, por me receberem em sua casa, pelo amor, apoio e confiança.

À Chica, minha querida amiga-mãezona, que me nutriu de baião-de-dois, farofa de cuscuz e de uma divertida companhia, debaixo do mesmo teto, durante quase todo o período do doutorado.

Aos meus pais, Elza e Gilberto, por nunca terem se oposto à minha persistente catação de conchas e pedras e, ao meu irmão, Fernando, por ainda incentivar essa mania.

Finalmente, ao CNPq (processo: 141800/2015-1), pelo financiamento dessa pesquisa, por meio da bolsa e reserva técnica, fundamental para a sua realização. 


\section{RESUMO}

CASATI, R. 2019. O registro climático e ambiental das conchas de sambaquis e depósitos paleolagunares na costa centro-sul catarinense. Tese de doutorado. IGcUSP.

Conchas de moluscos arquivam as condições climáticas e ambientais vigentes à época de vida dos organismos que as produziram, e mesmo após a sua morte, sob a forma de assinaturas tafonômicas, isotópicas e geoquímicas. No litoral centro-sul de Santa Catarina, encontram-se dois tipos de depósitos conchíferos formados entre

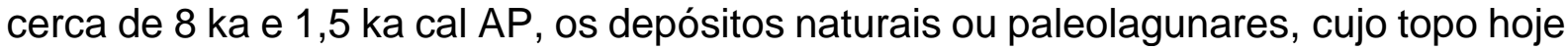
se situa cerca de $80 \mathrm{~cm}$ abaixo da superfície e, os sambaquis, sítios arqueológicos monticulares com até dezenas de metros de espessura, intencionalmente construídos e compostos predominantemente por conchas de Anomalocardia brasiliana oriundas das lagunas adjacentes. Esta pesquisa integra resultados de análise de fácies, composição taxonômica e caracterização tafonômica de depósitos conchíferos de ambos os tipos com datação e análise geoquímica $(\mathrm{Mg} / \mathrm{Ca}, \mathrm{Sr} / \mathrm{Ca}$ e $\mathrm{Ba} / \mathrm{Ca})$ e isotópica $\left(\delta^{13} \mathrm{C}\right.$ e $\left.\delta^{18} \mathrm{O}\right)$ de valvas de $A$. brasiliana neles coletadas. Estes resultados, que cobrem o intervalo de tempo aproximado de $7 \mathrm{ka}$ a $1,5 \mathrm{ka}$ AP, permitiram inferir que o declínio no NRM desde cerca de $5,5 \mathrm{ka}$, o fechamento progressivo do sistema lagunar, acelerado após essa data, e o aumento mais ou menos simultâneo na precipitação regional reduziram a salinidade média das águas desse sistema, e por consequência, as populações de $A$. brasiliana, sensível a salinidades abaixo de 17. Esta alteração ambiental, bem como o encolhimento dos bancos de moluscos por conta do assoreamento lagunar, diminuíram a disponibilidade de suas conchas como material construtivo dos sambaquis, o que ajuda a explicar o fato, constatado neste trabalho, de as camadas mais ricas em conchas inteiras serem, na estratigrafia dos depósitos arqueológicos, mais comuns nas fácies mais basais e antigas.

Palavras-chave: Sambaqui. Paleolaguna. Holoceno. Anomalocardia brasiliana. Santa Catarina. 


\section{ABSTRACT}

CASATI, R. 2018. Climatic and environmental record of shellmounds and paleolagoon shells deposits of the Santa Catarina coast. Doctoral thesis. IGc-USP.

Mollusk shells archive the climatic and environmental conditions prevailing at the time of the life of the organisms that produced them, and even after their death, in the form of taphonomic, isotopic and geochemical signatures. On the south-central coast of Santa Catarina there are two types of conchiferous deposits formed between about 8 $\mathrm{ka}$ and $1.5 \mathrm{ka}$ cal BP, the natural or paleolagunar deposits, whose top today is about $80 \mathrm{~cm}$ below the surface and, the sambaquis, archaeological shellmounds up to tens of meters thick, intentionally constructed and composed predominantly of Anomalocardia brasiliana shells from adjacent lagoons. This research integrates results of facies analysis, taxonomic composition and taphonomic characterization of conchiferous deposits of both types with dating and geochemical $(\mathrm{Mg} / \mathrm{Ca}, \mathrm{Sr} / \mathrm{Ca}$ and $\mathrm{Ba} / \mathrm{Ca})$ and isotopic $\left(\delta^{13} \mathrm{C}\right.$ and $\left.\delta^{18} \mathrm{O}\right)$ analysis of $A$. brasiliana valves. These results, which cover the approximate time interval from $7 \mathrm{ka}$ to $1.5 \mathrm{ka} \mathrm{BP}$, allowed to infer that the decline in RSL since about $5.5 \mathrm{ka}$, the progressive closure of the lagoon system, which accelerated after that date, and the more or less simultaneous increase in regional precipitation diminished the average salinity of the waters of this system and, consequently, the populations of $A$. brasiliana, sensitive to salinities below 17 . This environmental change, as well as the contraction of mollusk banks due to the lagoon siltation, has reduced the availability of their shells as a constructive material of the sambaquis, which helps to explain the fact that the richest layers of entire shells are, in the stratigraphy of archaeological deposits, more common in the more basal and older facies.

Keywords: Shellmound. Paleolagoon. Holocene. Anomalocardia brasiliana. Santa Catarina. 


\section{ÍNDICE DE FIGURAS}

Figura 1. Imagem de satélite da costa centro-sul de Santa Catarina com destaque para as ocorrências de sambaquis (Giannini et al., 2010). Imagem extraída do Google Earth.

Figura 2. Padrões estratigráficos dos sambaquis da costa centro-sul catarinense, segundo Giannini et al. (2010): A) conchífero (interestratificação entre lâminas de conchas inteiras ou quebradas e sedimentos areno-argilosos pretos): sambaqui Cabeçuda; B) núcleo arenoso (núcleo quartzo-arenoso monticular, maciço, sob capa de areia com conchas): sambaqui Carniça 3; C) montículo ictiológico, no topo da seção (misturas de areia com conchas e ossos queimados, com fragmentos líticos e cerâmicos e carvão): sambaqui Jaboticabeira 2. ......... 3

Figura 3. Mapa de sistemas deposicionais do litoral centro-sul catarinense (Giannini et al., 2010)

Figura 4. Três fases de evolução reconhecidas para a região, segundo Fornari et al. (2012): FEG 1 (7000 a 5000 anos cal AP); FEG 2 (5000 a 2500 anos cal AP); FEG 3 (2500 anos cal AP ao presente)

Figura 5. Mapa de distribuição espacial dos sambaquis da região entre Imbituba e Jaguaruna, de acordo com quatro setores principais (Giannini et al., 2010).

Figura 6. Contextos geológicos-geomorfológicos de distribuição dos sambaquis, baseados em Giannini et al. (2010)......

Figura 7. Histograma de distribuição de frequências de idades máximas por sambaqui. Idades referem-se a datações cal ${ }^{14} \mathrm{C}$ (conchas, carvão e ossos humanos). As linhas pontilhadas delimitam as fases de ocupação sambaquieira (FOS) em relação às fases de evolução geomorfológica ( $F E G$ ) e, dentro de cada intervalo estão citados os tipos estratigráficos mais comuns (tipos 1, 2 e 3) (baseado em Giannini et al., 2010 e em Fornari et al., 2012) 16

Figura 8. Fases de ocupação sambaquieira (F.O.S.) e sua contextualização em relação à evolução geomorfológica da região, que passou de uma grande baía a um sistema de lagunas intercomunicáveis (adaptado de Giannini et al., 2010).

Figura 9. Imagem de satélite da costa centro-sul de Santa Catarina com destaque para os depósitos analisados. Imagem extraída do Google Earth.

Figura 10. Sambaqui Cabeçuda. A) Seção exposta durante a exploração comercial de cal. B) Oficina lítica, em planta, localizada na área do sambaqui Cabeçuda.

Figura 11. Sambaqui Carniça 1, em visada rumo SW (laguna Santa Marta, ao fundo). Foto: P.C.F. Giannini.

Figura 12. Sambaqui Carniça 3, visto de NE. Foto: P.C.F. Giannini................................. 20

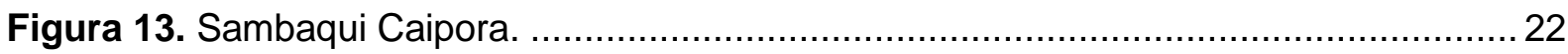

Figura 14. Sambaqui Garopaba do Sul, visto de NW. Foto: P.C.F. Giannini. ..................... 22

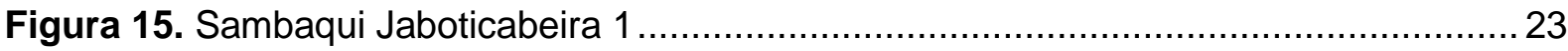

Figura 16. Sambaqui Jaboticabeira 2, em uma das frentes voltadas para SE. Foto: P.C.F.

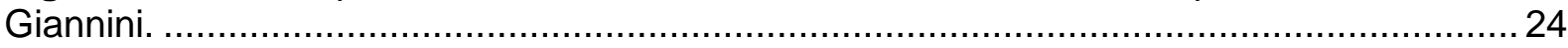

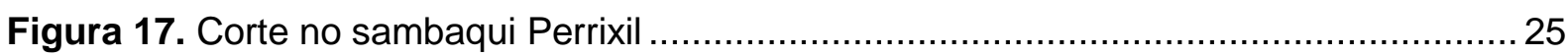

Figura 18. Sambaqui Santa Marta 2, visto a partir de sul. Foto: P.C.F. Giannini. ................ 26

Figura 19. Depósito paleolagunar CPL, próximo ao sambaqui Caipora. A) Fácies contendo conchas inteiras e em posição de vida; B) $\mathrm{O}$ bivalve Phacoides pectinatus com as valvas articuladas e na posição em que se encontrava no sedimento (posição de vida); C) Contato entre a fácies com conchas preferencialmente inteiras com a fácies mais cascalhosa com conchas fragmentadas; D) Detalhe da fácies com conchas retrabalhadas. 
Figura 20. Depósito paleolagunar GSL com a fácies conchífera na base e, sobrepondo-se a ela, uma fácies arenosa, mais clara e, uma fácies areno-lamosa, mais escura. ..................28

Figura 21. Seção 1 escolhida para coleta no sambaqui Cabeçuda (CB1): ........................... 38

Figura 22. Depósito paleolagunar exposto por meio de trincheira (CNL), exibindo a proximidade do lençol freático com a fácies conchífera.

Figura 23. Exemplo de divisão em camadas ( $C 1$ a $C 7)$ e em fácies ( $A C, C A c m, C i A, A c m C$, A). As camadas não se repetem por serem estratigraficamente confinadas, ao contrário do que pode acontecer com as fácies, como em CAcm e em CiA, onde há recorrências entre 86 e $100 \mathrm{~cm}$. .40

Figura 24.Seção do sambaqui Caipora exposta e dividida segundo cotas de amostragem (de $5 \mathrm{em} 5 \mathrm{~cm}$ ) pré-determinadas, demarcadas por varetas de madeira...... 41

Figura 25. Coleta e acondicionamento das amostras para datação e análises isotópicas e geoquímicas (D.I.G.) na seção GS2.....

Figura 26.Procedimento de coleta de amostras para a análise petrográfica exemplificada pela camada CB2-C2: 1) esculpimento de um cubo na fácies e aspersão de água sobre ele; 2) envolvimento das laterais do cubo com atadura gessada molhada; 3) remoção da amostra; 4) desbastamento da face interna (voltada para a parede); 5) cobertura com papel higiênico das áreas não-gessadas e identificação do topo; 6) envolvimento da amostra com plástico filme e plástico bolha e identificação da amostra na fita crepe envoltória.

Figura 27. Valva de $A$. brasiliana seccionada para diferentes finalidades: a porção em azul foi direcionada para determinação da idade via ${ }^{14} \mathrm{C}$ AMS; do restante, em laranja, foram extraídas, as alíquotas para as análises isotópicas e geoquímicas a partir do eixo de maior crescimento da concha, destacado pela linha pontilhada..... .45

Figura 28. Valva de $A$. brasiliana com alteração química em sua superfície. Escala: $10 \mathrm{~mm}$.

Figura 29. Principais passos da preparação para análise D.I.G.: 1) impregnação das valvas com resina epóxi, com eixo de maior crescimento previamente marcado a lápis; 2) seccionamento do cubo de resina no eixo de maior crescimento da concha e; 3) polimento no esmeril com carbeto de silício. .46

Figura 30. Amostragem, com uso de micro-pulverizador, de alíquotas de $\mathrm{CaCO}_{3}$ do cerne da concha embutida em resina epóxi. .46

Figura 31. Equipamento utilizado na análise dos isótopos estáveis: GasBench acoplado a um espectrômetro de massas de razão isotópica.

Figura 32. Procedimentos de preparação de amostras para as análises geoquímicas:....... 47

Figura 33. Principais passos da impregnação de amostras para a análise petrográfica: 1) preenchimento do recipiente contendo a amostra, com resina corada; 2) acondicionamento das amostras em um dessecador e aplicação de vácuo por 2min; 3) repetição das etapas 1 e 2 ; 4) secagem das amostras em estufa por mais $24 \mathrm{~h}$; 5 ) orientação e identificação das amostras a serem seccionadas. .48

Figura 34. Preparação e coleta de dados granulométricos: 1) seleção de 200 g de amostra; 2) dispersão em $\sim 200 \mathrm{~mL}$ de água deionizada com $1 \mathrm{~g}$ de $\mathrm{Na}_{2} \mathrm{P}_{2} \mathrm{O}_{7} .3 \mathrm{H}_{2} \mathrm{O}$, por $\sim 2 \mathrm{~min}$; 3) peneiramento em malha de $2 \mathrm{~mm}$ com água deionizada; 4) agitação do passante com haste de base circular em proveta; 5 ) pipetagem de $20 \mathrm{ml}$ após $58 \mathrm{~s}$, a $20 \mathrm{~cm}$ de profundidade; 6) transferência do pipetado para um becker de $50 \mathrm{ml}$; 7) elutriação do restante do material; 8) filtragem do elutriado e o cascalho.....

Figura 35. Preparação e coleta de dados granulométricos (continuação): 9) secagem, em estufa, do elutriado, do cascalho e do pipetado; 10) peneiramento do elutriado em classes de 1 phi; 11) pesagem de cada fração granulométrica. 
Figura 36. Assinaturas tafonômicas (cf. Tabela 1) observadas em conchas de A. brasiliana: A) perióstraco preservado e brilho original; B) graus de fragmentação; C-E) modificação da superfície: C) graus de dissolução; D) graus de oxidação; E) graus de precipitação. As alterações superficiais foram observadas externa e internamente. Barra de escala: $10 \mathrm{~mm}$. Todas as imagens obtidas a partir de espécimes dos sambaquis e concheiros naturais em estudo, exceto pelo espécime "A", recente (foto: www.conchology.be).

Figura 37. Fotos das amostras, feitas previamente à análise de MEV e EDS: A) CB1-C2; B) CN3-C2;

Figura 38. Distribuição das idades obtidas via ${ }^{14} \mathrm{C}$ AMS de conchas de $A$. brasiliana (círculos amarelos) e de carvões (círculos vermelhos), nos depósitos paleolagunares (linhas rosa) e nos sambaquis (linhas azuis). Os pontos representam a mediana do intervalo de idade calibrada. 56

Figura 39. Histograma de idades ${ }^{14} \mathrm{C}$ obtidas em carvões de sambaquis e em conchas de sambaquis e de depósitos paleolagunares.

Figura 40. Sambaquis organizados em sequência cronológica, baseado nas médias de idades obtidas em cada sítio. Notar as coincidências entre média e mediana na maioria dos casos. Notar também como as barras de desvio padrão dos diferentes sítios apresentam mais sobreposição entre si nas idades mais jovens.

Figura 41. Seções colunares dos depósitos paleolagunares. Idades das conchas em vermelho.

Figura 42. Seção colunar e descrição faciológica do sambaqui Caipora com a distribuição das idades das conchas (em vermelho).

Figura 43. Seção colunar e descrição faciológica do sambaqui Santa Marta 2 com a distribuição das idades das conchas (em vermelho) e dos carvões (em azul).

Figura 44. Seção colunar e descrição faciológica da Seção 1 do sambaqui Cabeçuda com a distribuição das idades das conchas (em vermelho).

Figura 45. Seção colunar e descrição faciológica da Seção 2 do sambaqui Cabeçuda com a distribuição das idades das conchas (em vermelho) e dos carvões (em azul).

Figura 46. Seção colunar e descrição faciológica do sambaqui Carniça 3 com a idade de uma concha (em vermelho) obtida por Giannini et al. (2010).

Figura 47. Seção colunar e descrição faciológica da Seção 1 do sambaqui Garopaba do Sul com a distribuição das idades das conchas (em vermelho) e dos carvões (em azul).

Figura 48. Seção colunar e descrição faciológica da Seção 2 do sambaqui Garopaba do Sul com a distribuição das idades das conchas (em vermelho) e dos carvões (em azul)...... 66

Figura 49. Seção colunar e descrição faciológica do sambaqui Jaboticabeira $1 \mathrm{com}$ a distribuição das idades das conchas (em vermelho) e dos carvões (em azul).

Figura 50. Seção colunar e descrição faciológica da Seção 2 do sambaqui Carniça 1 com a distribuição das idades das conchas (em vermelho).

Figura 51. Seção colunar e descrição faciológica da Seção 3 do sambaqui Carniça 1 com a distribuição das idades das conchas (em vermelho).

Figura 52. Seção colunar e descrição faciológica da Seção 1 do sambaqui Perrixil com a distribuição das idades das conchas (em vermelho).....

Figura 53. Seção colunar e descrição faciológica da Seção 2 do sambaqui Perrixil com a distribuição das idades das conchas (em vermelho) e dos carvões (em azul).

Figura 54. Seção colunar e descrição faciológica do sambaqui Jaboticabeira 2 com a distribuição das idades das conchas (em vermelho) e dos carvões (em azul). 
Figura 55. Relação das frações granulométricas observadas para cada fácies levantada nas paleolagunas. $\mathrm{N}=8$. .70

Figura 56. Relação das frações granulométricas observadas para cada fácies levantada nos sambaquis. $\mathrm{N}=35$.

Figura 57. Gráficos de caixa (box-plot) comparando seixos, classes granulométricas de phi entre seixo e areia muito fina e teor de pelíticos total entre os depósitos paleolagunares e os sambaquis.

Figura 58. Gráficos de caixa (box-plot) comparando as estatísticas da distribuição granulométrica dos quatro primeiros momentos, entre os depósitos paleolagunares e os sambaquis. $\mathrm{N}=43$. .73

Figura 59. Composição taxonômica dos depósitos paleolagunares analisados com domínio de $A$. brasiliana em todos os casos; apenas o depósito CPL possui registro expressivo de $C$. brasiliana em relação aos demais. 78

Figura 60. Composição taxonômica dos sambaquis analisados com domínio de A. brasiliana na maioria dos casos, exceto pelos sambaquis Caipora e Jaboticabeira 1, onde dominam conchas de $C$. brasiliana......

Figura 61. Composição taxonômica dos depósitos paleolagunares analisados, excetuandose $A$. brasiliana e $C$. brasiliana.

Figura 62. Composição taxonômica dos sambaquis analisados, excetuando-se $A$. brasiliana

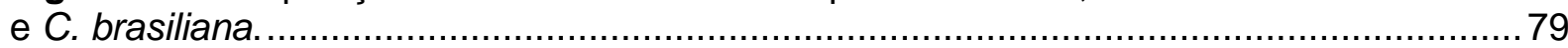

Figura 63. Graus de fragmentação entre os depósitos paleolagunares............................. 80

Figura 64. Graus de dissolução entre os depósitos paleolagunares................................. 81

Figura 65. Graus de oxidação entre os depósitos paleolagunares. ..................................... 81

Figura 66. Graus de precipitação entre os depósitos paleolagunares. ................................. 82

Figura 67. Graus de fragmentação entre os sambaquis................................................ 82

Figura 68. Graus de dissolução entre os sambaquis................................................... 83

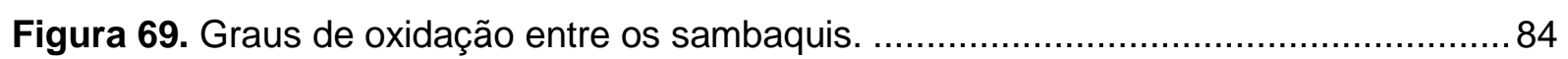

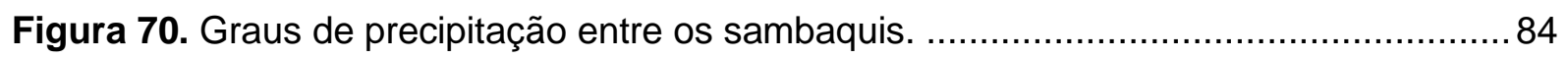

Figura 71. Comparação entre depósitos paleolagunares e sambaquis, ao longo do tempo, quando à frequência de conchas quebradas em grau máximo (3) .................................... 85

Figura 72. Comparação entre depósitos paleolagunares e sambaquis, ao longo do tempo, quando à frequência de conchas com dissolução em grau máximo (3) . ............................86

Figura 73. Comparação entre depósitos paleolagunares e sambaquis, ao longo do tempo, quando à frequência de conchas com oxidação em grau máximo (3) ............................... 86

Figura 74. Comparação entre depósitos paleolagunares e sambaquis, ao longo do tempo, quando à frequência de conchas com precipitação em grau mínimo (0).

Figura 75. Análise da alteração superficial de uma concha de $A$. brasiliana da camada 1 do depósito paleolagunar Caipora (CPL2-C1): A) superfície da concha com crosta amareloalaranjada; B) roseta de gipsita em meio à massa de argilominerais; C-D) frústulas de diatomáceas (Paralia sulcata) em meio a argilominerais.

Figura 76. Análise da alteração superficial de uma concha de $A$. brasiliana da camada 1 do depósito paleolagunar Perrixil (PXL-C1): A) superfície da concha branco-azulada, sem brilho original; B-C) crosta de reprecipitação de calcita (contendo impurezas de argilominerais) com orifícios circulares e, mais raramente, calhas alongadas. 
Figura 77. Análise da alteração superficial de uma concha de $A$. brasiliana da camada 2 do sambaqui Cabeçuda (CB1-C2): A) crosta marrom avermelhada apresentando grãos de areia aderidos; B) espectro típico da associação entre apatita $(\mathrm{P}, \mathrm{Ca})$ e argilominerais $(\mathrm{Si}, \mathrm{Al}, \mathrm{Mg}$, K); C) grãos de areia aderidos à superfície da concha; D-F) argilominerais e, dominantemente, apatita, a qual ocorre como agregados fibrorradiados de prismas e agulhas, com até $40 \mu \mathrm{m}$ de diâmetro; G) camadas, paralelas à superfície da concha e envolvendo os grãos de areia, constituídas por cristais perpendiculares de apatita de menos de $3 \mu \mathrm{m}$ de comprimento (fosfamicrita); H) crateras em padrão fractal sugestivas de dissolução parcial da crosta de apatita.

Figura 78. Análise da alteração superficial de uma concha de $A$. brasiliana da camada 2 do sambaqui Carniça 3 (CN3-C2): A) impregnações de cor preta sobre a superfície branca da concha; B) microanálise química por EDS de cristais prismáticos de calcita visíveis em meio às zonas pretas, com enriquecimento de $\mathrm{Ca}$ e empobrecimento de $\mathrm{C}$ em relação ao restante da crosta; C-D) material reprecipitado, formando faixas alongadas e sinuosas de $50 \mu \mathrm{m}$ de largura por até $1 \mathrm{~mm}$ de extensão; E) filamentos, com até $50 \mu \mathrm{m}$ de comprimento, de possível composição carbonosa

Figura 79. Análise da alteração superficial de uma concha de $A$. brasiliana da camada 1 do sambaqui Garopaba do Sul (GS2-C1): A) superfície com crosta amarelo-alaranjada; B) crosta de apatita associada a argilominerais, de aspecto coloidal, gretado; C) tufos de cristais prismáticos. 92

Figura 80. Análise da alteração superficial de uma concha de $A$. brasiliana da camada 2 do sambaqui Santa Marta 2 (SM-C2): A) superfície da concha com crosta de impregnação pardoamarelada; B) presença marcante, nesta crosta, de $\mathrm{P}, \mathrm{Ca}, \mathrm{Cl}, \mathrm{F}$, os quais variam juntos, sugerindo associação com flúor-apatita e/ou cloro-apatita; C) aspecto geral da crosta de apatita criptocristalina, revestida em padrão drusiforme por cristais maiores do mesmo mineral; D) cristais com hábito em folhas de alface e com fibras na terminação (possível presença de esmectita e illita; E e F) detalhes dos cristais prismáticos de apatita com até cerca de $15 \mu \mathrm{m}$ de comprimento.).

Figura 81. Análise da alteração superficial de uma concha de $A$. brasiliana da camada 3 do sambaqui Santa Marta 2 (SM-C3): A) superfície da concha com crosta preta; B) crosta de apatita e argilominerais, com grãos de areia terrígena (sobretudo de quartzo) aderidos; C) Si em padrão de distribuição "pipocado"; D) prismas curtos cripto a microcristalinos de apatita; E) esferólito de apatita, com cerca de $15 \mu \mathrm{m}$ de diâmetro; F-H) agregados de minúsculos grãos elipsoides $(\sim 1 \mu \mathrm{m})$, que lembram bacilos e fibras vegetais intimamente aderidas à crosta na superfície da concha.

Figura 82. Valores de $\delta^{18} \mathrm{O}(\mathrm{V}-\mathrm{PDB}) \%$ em conchas de sambaquis e 95

Figura 83. Valores de $\delta^{13} \mathrm{C}$ (V-PDB) \%o em conchas de sambaquis e de depósitos paleolagunares ao longo do tempo. $N=99$. $R=0,762 ; P=0,005$.

Figura 84. Variação da razão $\mathrm{Mg} / \mathrm{Ca}$ em conchas de sambaquis e de depósitos paleolagunares ao longo do tempo. $N=99$. $R=-0,098$.

Figura 85. Variação da razão $\mathrm{Sr} / \mathrm{Ca}$ em conchas de sambaquis e de depósitos paleolagunares ao longo do tempo. $N=99$. $R=-0,638$.

Figura 86. Variação da razão $\mathrm{Ba} / \mathrm{Ca}$ em conchas de sambaquis e de depósitos paleolagunares ao longo do tempo. $\mathrm{N}=99$. $\mathrm{R}=0,07$. 98

Figura 87. Cimento fosfático: A) intraclasto de cimento fosfático, restos de osso e grãos de quartzo (GS2-C3; AFS1); B) concha de molusco com revestimento cimento fosfático colofânico (JB-C1; AFS5); C) craca preenchida por cimento fosfático (JB-C1; AFS5). A1, B1 e C1: polarizadores paralelos. A2, B2 e C2: polarizadores cruzados. 102 
Figura 88. Cimento carbonático: A) microespato (CN3-C1; AFS7); B) película de carbonato reprecipitado em torno de bioclasto de molusco (JC-C1; AFS4); C) intraclasto de micrita mecanicamente deformado, associado a pellets (GS2-C3; AFS1). A1, B1 e C1: polarizadores paralelos. A2, B2 e C2: polarizadores cruzados. 103

Figura 89. Fragmentos de carvão: A) carvão fragmentado (JB-C1; AFS5)em meio a fragmentos de conchas e areia terrígena; B) carvão amassado por grãos rígidos de quartzo (GS2-C3; AFS1). A1, B1: polarizadores paralelos. A2, B2: polarizadores cruzados..... 104

Figura 90. Fotomicrografias, a polarizadores paralelos, do depósito paleolagunar CPL2-C1 pertencente a AFL2: A. seixo anguloso de quartzo em meio a areia média a muito fina, com pouca protomatriz lamosa; B. possível bioturbação; C. areia e seixos de quartzo e bioclasto carbonático; D. bioclasto de bivalve; E. intraclasto de lama orgânica; F. detalhe do cimento argilo-orgânico-ferruginoso 109

Figura 91. Fotomicrografias a polarizadores paralelos do depósito paleolagunar PXL-C1 pertencente a AFL3. Notar: bioclastos rudáceos de bivalves (A, B); grão de gastrópode na granulação areia muito grossa $(B)$; possíveis vestígios de carvão $(C, D)$; bioclasto de osso $(E)$; túnel de bioturbação, com pellets (F); Notar ainda, em todas as imagens, a presença de areia quartzosa fina a média, bem selecionada.

111

Figura 92. Fotomicrografias a polarizadores paralelos do depósito paleolagunar JBL-C2 pertencente a AFL4. Notar: bioclastos de gastrópode em meio a areia mista, terrígenobioclástica $(A, B, E)$; C. bioclastos de bivalves imbricados, com fragmentos de ossos esparsos (C, D, E, F)..... 112

Figura 93. Fotomicrografias a polarizadores paralelos de detalhes da matriz arenosa da camada 3 do sambaqui Garopaba do Sul (GS2-C3), pertencente a AFS1: A. intraclastos de matriz foasfamicrítica (grão amarelo, à esquerda) e calcimicrítica; $B$. intraclasto amassado de calcifosfamicrita, com túnel de bioturbação preenchido por pellets; C. peloide intraclástico de calcimicrita; D. fragmento de carvão mecanicamente deformado; E. peloide de calcimicrita; F. pellets em porosidade intergranular. 116

Figura 94. Fotomicrografias da camada 4 do sambaqui Caipora (CP-C4) pertencente a AFS2: A. bioclastos de conchas e osso queimado, em meio a areia fina a média; B. grãos terrígenos e fragmentos de conchas e ossos; notar amassamento da concha no canto inferior direito; C, $D$. concha de ostra fraturada diageneticamente, ao lado de fragmento de osso queimado. Imagens a polarizadores paralelos (A, B, C) e cruzados (D). 117

Figura 95. Fotomicrografias a polarizadores paralelos da camada 2 do sambaqui Cabeçuda (CB1-C2), pertencente a AFS3. Notar areia terrígena bem selecionada, bioclasto de concha perfurado, provavelmente por dissolução $(B)$, bioclasto de osso $(C)$ e mineral pesado mais fino que o quartzo $(C, D)$.

Figura 96. Fotomicrografias a polarizadores paralelos da camada 1 do sambaqui Jaboticabeira 1 (JC-C1), pertencente a AFS4: A. bioclasto rudáceo de concha de molusco, com duplo revestimento: de microespato e de cimento fosfático granular; B. bioclasto carbonático com preenchimento alveolar (honeycomb) por cimento fosfático, cercado por fosfato bioclástico mais fino; C. peloide intraclástico de micrita; D. concha com cimento de microespato, retrabalhados. 119

Figura 97. Fotomicrografias a polarizadores paralelos da camada 1 do sambaqui Jaboticabeira 2 (JB-C1) pertencente a AFS5: A. cascalho bioclástico conchífero, com areia terrígena e fragmentos de carvão; B. bioclasto de gastrópode em meio a areia formada por terrígenos, ossos e carvão; C. bioclastos de moluscos, subparalelamente alinhados; notar também: peloide de micrita, fragmentos delgados de ossos e cimento fosfático revestindo a concha do meio da imagem; D. bioclasto de craca, com cimento intragranular de fosfamicrita. 
Figura 98. Fotomicrografias a polarizadores paralelos da camada 2 do sambaqui Garopaba do Sul (GS2-C2) pertencente a AFS6: A. concha com cimento anisópaco de fosfato; B. bioclasto de craca; C. bioclastos de ossos; D. túnel de bioturbação com preenchimento por pellets; E. bioclasto de osso; F. bioclastos de concha e de osso. Notar, em todas as imagens, presença de areia terrígena fina a média, bem selecionada.

Figura 99. Fotomicrografias a polarizadores paralelos da camada 1 do sambaqui Carniça (CN3-C1) pertencente a AFS7: A. túnel de biotrbação, com preenchimento por pellets fosfáticos; B. peloide de callcimicrita, bioclastos de molusco e fragmento de osso com porosidade intragranular alveolar; $\mathrm{C}$. bioclasto ladeado por calcimicrita, aparentemente amassada (pseudomatriz carbonática); D. ossos e possíveis pellets carbonosos 122

Figura 100. Diagrama de distribuição no tempo das associações de fácies contendo cascalho de conchas de $A$. brasiliana dominantemente inteiras, com ou sem matriz de areia ou lama (AFS1, AFS3 e AFS4). Para a elaboração do gráfico, considerou-se o intervalo inteiro de cada datação ${ }^{14} \mathrm{C}$. 123

Figura 101. Diagrama de distribuição no tempo da associação de fácies de cascalho de ostras inteiras em matriz de concha moída (AFS2). Para a elaboração do gráfico, considerou-se o intervalo inteiro de cada datação ${ }^{14} \mathrm{C}$. 124

Figura 102. Diagrama de distribuição no tempo das associações de fácies contendo cascalho de conchas de $A$. brasiliana quebradas e/ou matriz de conchas ou ossos moídos (AFS5, AFS6 e AFS7). Para a elaboração do gráfico, considerou-se o intervalo inteiro de cada datação ${ }^{14} \mathrm{C}$.

Figura 103. Diagrama de distribuição no tempo da associação de fácies de areia lamosa com matriz de ossos moídos (AFS8). Para a elaboração do gráfico, considerou-se o intervalo inteiro de cada datação ${ }^{14} \mathrm{C}$ 125

Figura 104. Representação esquemática das associações de fácies interpretadas por Giannini et al. (2009) e Menezes (2009) no sambaqui Jaboticabeira 2. Seção composta: L2 sob B. 126

Figura 105. Confronto entre dados da literatura $(A, B)$ e os resultados obtidos nesse trabalho (C-G): A) curva do NRM para o Estado de Santa Catarina (Angulo et al., 2006); B) $\delta^{18} \mathrm{O}$ de uma estalagmite da caverna Botuverá localizada no mesmo Estado (Bernal et al., 2016); C$\mathrm{G})$ valores de $\delta^{18} \mathrm{O}(\mathrm{C}), \delta^{13} \mathrm{C}(\mathrm{D})$ e das razões elementares de $\mathrm{Mg} / \mathrm{Ca}(\mathrm{E}), \mathrm{Sr} / \mathrm{Ca}(\mathrm{F})$ e $\mathrm{Ba} / \mathrm{Ca}$ (G) de conchas de $A$. brasiliana de sambaquis e depósitos paleolagunares. 133

Figura 106. Análise de componentes principais: componente 1 (mais influenciado por $\sigma^{18} \mathrm{O}$ e $\sigma^{13} \mathrm{C}$ e, inversamente, por $\mathrm{Sr} / \mathrm{Ca}$ ) versus componente 2 (mais influenciado inversamente por $\mathrm{Ba} / \mathrm{Ca}$ e $\mathrm{Mg} / \mathrm{Ca}$ ). Os polígonos coloridos indicam agrupamentos de conchas por idade $(\mathrm{k}=$ milhares de anos). 137

Figura 107. Análise de componentes principais: componente 1 (mais influenciado por $\sigma^{18} \mathrm{O}$ e $\sigma^{13} \mathrm{C}$ e, inversamente, por $\mathrm{Sr} / \mathrm{Ca}$ ) versus componente 3 (mais influenciado por $\mathrm{Ba} / \mathrm{Ca}$ e $\mathrm{Mg} / \mathrm{Ca}$ ). Os polígonos coloridos indicam agrupamentos de conchas por idade $(\mathrm{k}=$ milhares de anos). 138 


\section{ÍNDICE DE TABELAS}

Tabela 1. Siglas adotadas para representar granulações e estruturas sedimentares, nos

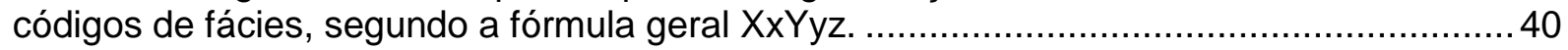

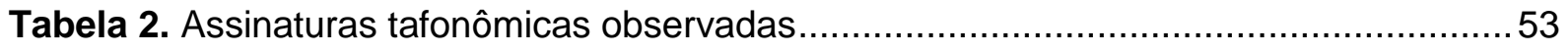

Tabela 3. Amostras datadas de carvão pareadas com conchas de A. brasiliana..................55

Tabela 4. Relação e descrição das fácies observadas nos depósitos paleolagunares. ........60

Tabela 5. Relação e descrição das fácies observadas nos sambaquis..............................61

Tabela 6. Composição malacológica observada nos sambaquis e depósitos paleolagunares, com informações de habitat e ocorrência compiladas de Souza et al. (2011). ..................... 74

Tabela 7. Tipos de alteração observados na superfície das conchas de sambaquis ...........87

Tabela 8. Associações de fácies dos depósitos paleolagunares....................................... 107

Tabela 9. Idades ${ }^{14} \mathrm{C}$ AMS obtidas para amostras de concha de moluscos de lama arenosa a areia lamosa preta, incluindo bivalves em posição de vida ( $\left.{ }^{*}\right)$, da paleolaguna Garopaba do Sul, próximo ao sambaqui homônimo. Depósitos correlatos a AFL2. Dados de Giannini et al.

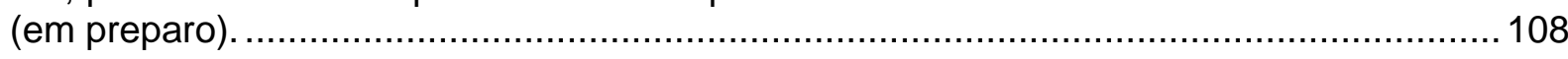

Tabela 10. Associações de fácies de sambaquis.............................................................114

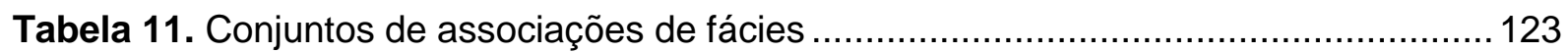

Tabela 12. Correlação cronológica entre associações de fácies lagunares e de sambaquis. $\mathbf{X}$ negrito: ocorrência modal. Número negrito preto: idade máxima obtida em AFL. Número negrito azul: idade mínima obtida em sambaqui. Demais idades são aproximadas, com base no predomínio no conjunto de dados de datações desta tese. Deposição de AFL 3 a AFL5 é contínua a partir de 5300 anos AP

Tabela 13. Composição dos tipos de alteração observados na superfície das conchas de sambaquis (AFS) e de depósitos paleolagunares (AFL). 135 


\section{SUMÁRIO}

1. INTRODUÇÃO: QUESTÕES CIENTÍFICAS E HIPÓTESES DE TRABALHO..........1

2. OBJETOS DE ESTUDO

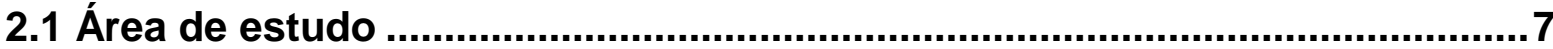

2.1.1 Nível relativo do mar, clima e paleoclima............................................

2.1.2 Distribuição dos sistemas deposicionais quaternários ..............................

2.1.3 Evolução da sedimentação lagunar ..................................................... 11

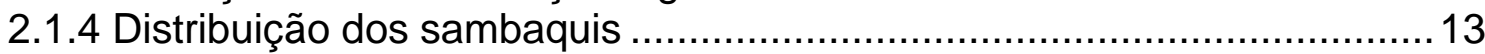

2.1.5 Evolução da ocupação sambaquieira ………...................................... 14

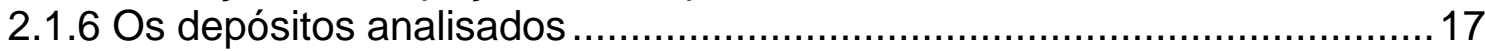

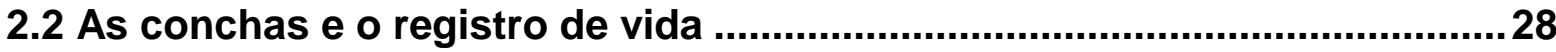

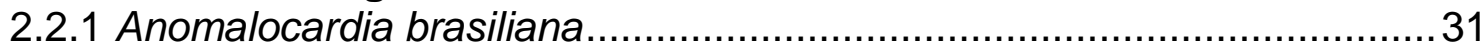

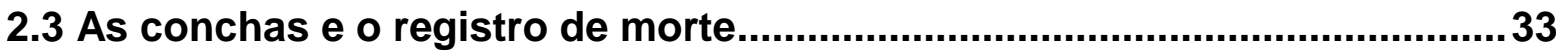

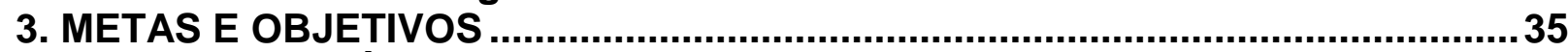

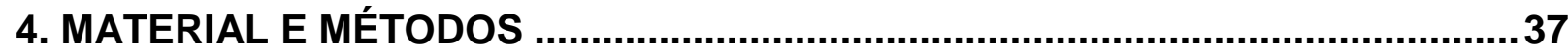

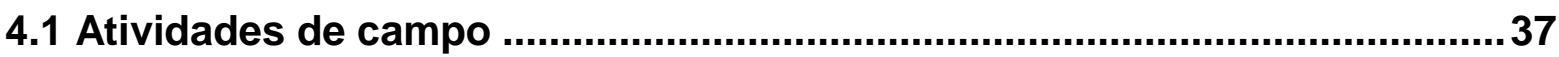

4.1.1 Seleção e exposição das áreas de coleta.............................................37

4.1.2 Aspectos operacionais da análise de fácies .........................................39

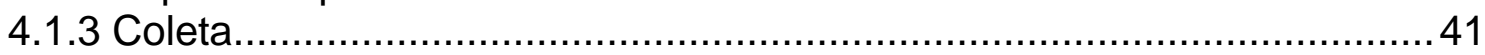

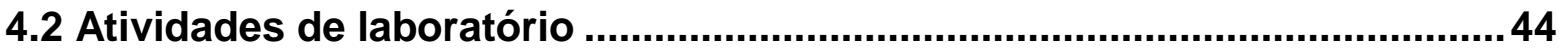

4.2.1 Datação e análises isotópicas e geoquímicas ......................................4 44

4.2.2 Análise petrográfica .................................................................... 47

4.2.3 Análise sedimentológica ................................................................ 49

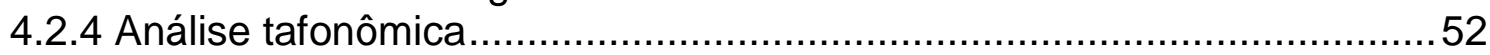

5. RESULTADOS

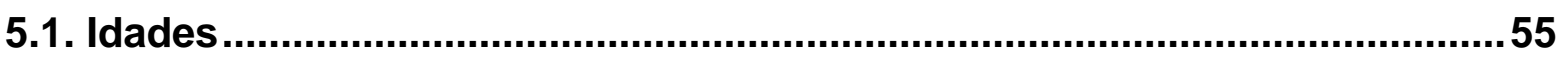

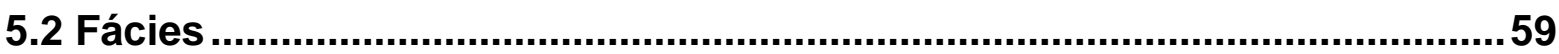

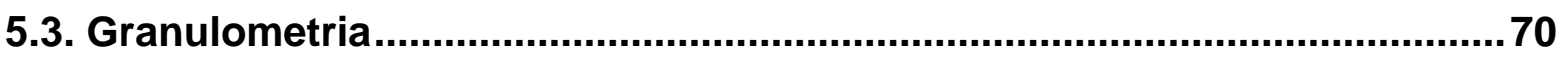

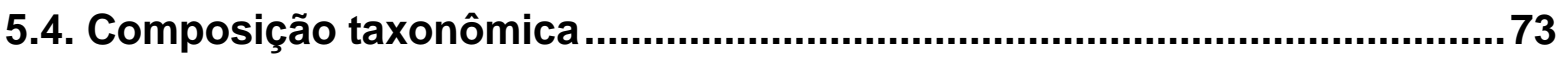

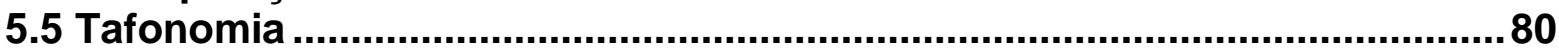

5.5.1 Caracterização tafonômica dos depósitos ……….............................. 80

5.5.2 Evolução cronológica das assinaturas tafonômicas..................................8. 84

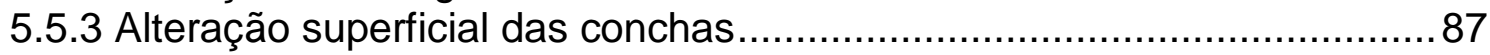

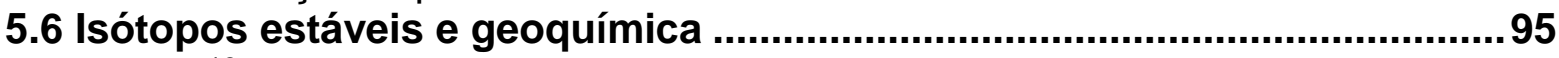

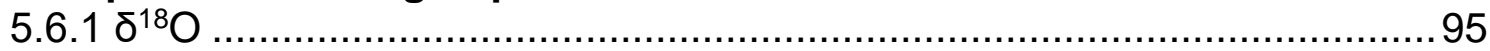

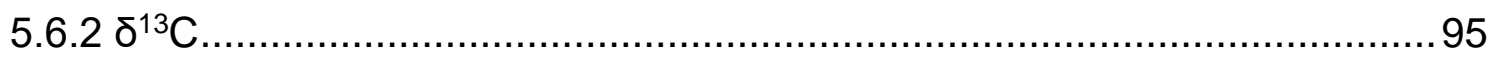

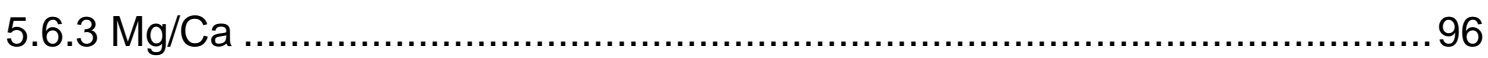

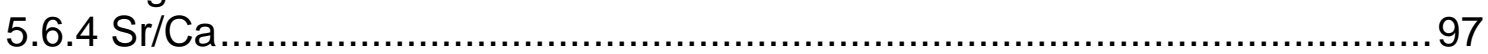

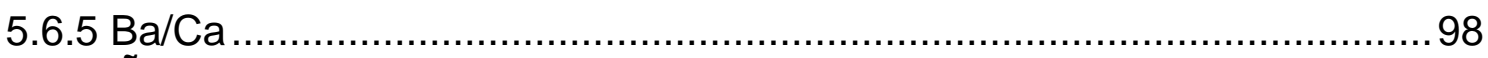

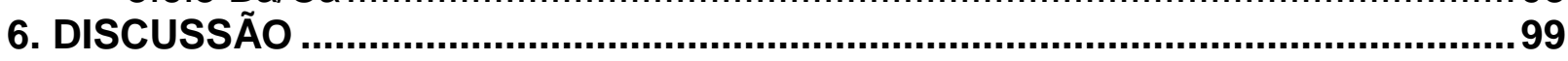

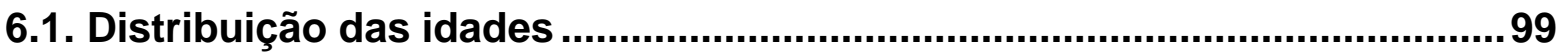

6.2 Sambaquis versus depósitos paleolagunares.........................................101

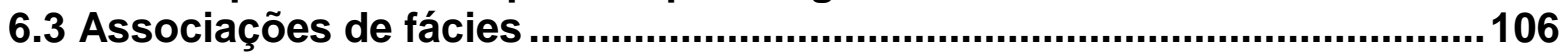

6.3.1 Associações de fácies lagunares ...................................................106

6.3.2 Associações de fácies de sambaquis ..................................................113

6.4 Evolução ambiental e mudança na composição faunística .......................128

6.5 Análise de componentes principais .........................................................135

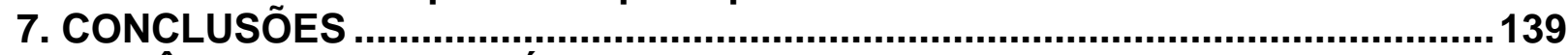

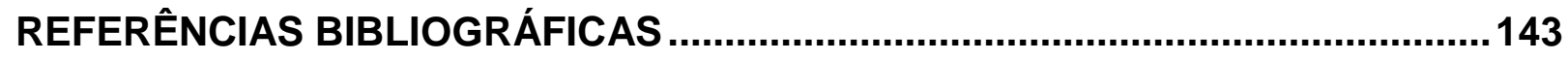




\section{INTRODUÇÃO: QUESTÕES CIENTÍFICAS E HIPÓTESES DE TRABALHO}

"A própria natureza tem história, e as conchas são alguns entre os documentos dessa história” (Rossi, 1992, p.23)

Conchas de moluscos são verdadeiros registros das condições ambientais e climáticas do passado. Cada concha arquiva em si a história de vida do molusco que a produziu, incluindo a temperatura e salinidade do meio onde ele se desenvolveu, assim como a relação ecológica com outros organismos, como crustáceos, anelídeos, outros moluscos e, inclusive nós, seres humanos. Este é o seu "registro de vida", que encerra os eventos transcorridos do nascimento até a morte do molusco, codificados em assinaturas paleoecológicas, isotópicas e geoquímicas.

Após a morte do animal, a concha passa a registrar outro tipo de informação: a tafonômica, ou seu "registro de morte", que abrange processos de duas categorias: bioestratinômicos e diagenéticos; os processos bioestratinômicos são aqueles transcorridos desde a morte até o soterramento, incluindo o transporte mecânico e seus efeitos como a desarticulação das valvas, sua abrasão e fragmentação e a seleção hidráulica de tamanho; os processos diagenéticos compreendem as alterações físico-químicas sofridas pelas conchas após o soterramento, isto é, dizem respeito diretamente às condições do depósito em que se encontram.

No contexto costeiro, em que se insere este trabalho, os depósitos conchíferos que contêm o registro das condições ambientais e climáticas dos últimos milênios (Holoceno) podem ser de dois tipos, natural ou antropogênico. O primeiro ocorre em meio a sedimentos de antigas lagunas e baías, por isso também designados paleolagunares; as fácies conchíferas dos depósitos paleolagunares, ou tafocenoses, são compostas por uma rica diversidade de espécies, de proveniência variada, sejam remobilizadas por agentes naturais, como ondas e correntes de maré, sejam, mais raramente, deixadas in situ em posição de vida. O segundo tipo de deposito conchífero costeiro são os sambaquis, sítios arqueológicos monticulares, intencionalmente construídos, caracterizados por estratos dômicos superimpostos, comumente, mas não exclusivamente, associados a sepultamentos humanos; as conchas que constituem os sambaquis costeiros são predominantemente de Anomalocardia brasiliana ou de ostras, oriundas da laguna ou baia adjacente. 
É na região costeira centro-sul do Estado de Santa Catarina, entre os municípios de Imbituba e Jaguaruna (Figura 1), que se encontram os maiores montes de conchas do mundo, podendo chegar a mais de $30 \mathrm{~m}$ de altura e $500 \mathrm{~m}$ de comprimento, caso dos sambaquis Garopaba do Sul e Carniça 1. Os sambaquis desta região às vezes registram deposição contínua por pelo menos 1000 ou 2000 anos, como nos sítios Jaboticabeira 2 e Jaboticabeira 1, respectivamente (De Blasis et al., 2007; Giannini et al., 2010).

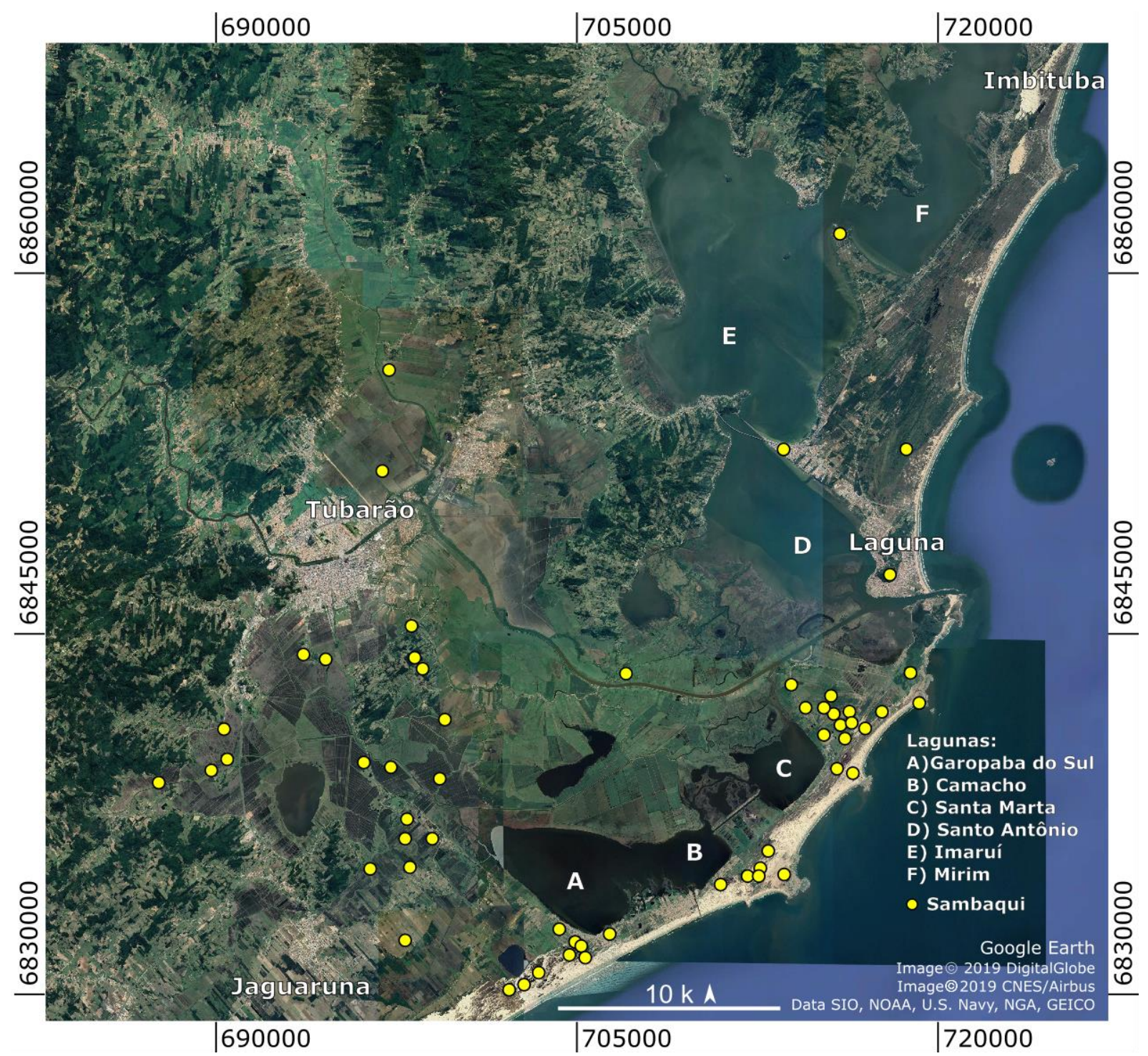

Figura 1. Imagem de satélite da costa centro-sul de Santa Catarina com destaque para as ocorrências de sambaquis (Giannini et al., 2010). Imagem extraída do Google Earth. 
Em seção, é possível identificar nos sambaquis da costa centro-sul catarinense três tipos ou padrões estratigráficos distintos (Giannini et al. 2010; Figura 2): o padrão conchífero corresponde à interestratificação entre lâminas de conchas e lâminas mais delgadas de sedimentos pretos; o padrão núcleo arenoso possui camada interna monticular quartzo-arenosa, maciça, sob capa de areia com conchas; e o padrão depósito ictiológico consiste de misturas maciças ou mal estratificadas de areia com conchas e ossos queimados, contendo também fragmentos líticos, cerâmicos e carvão.
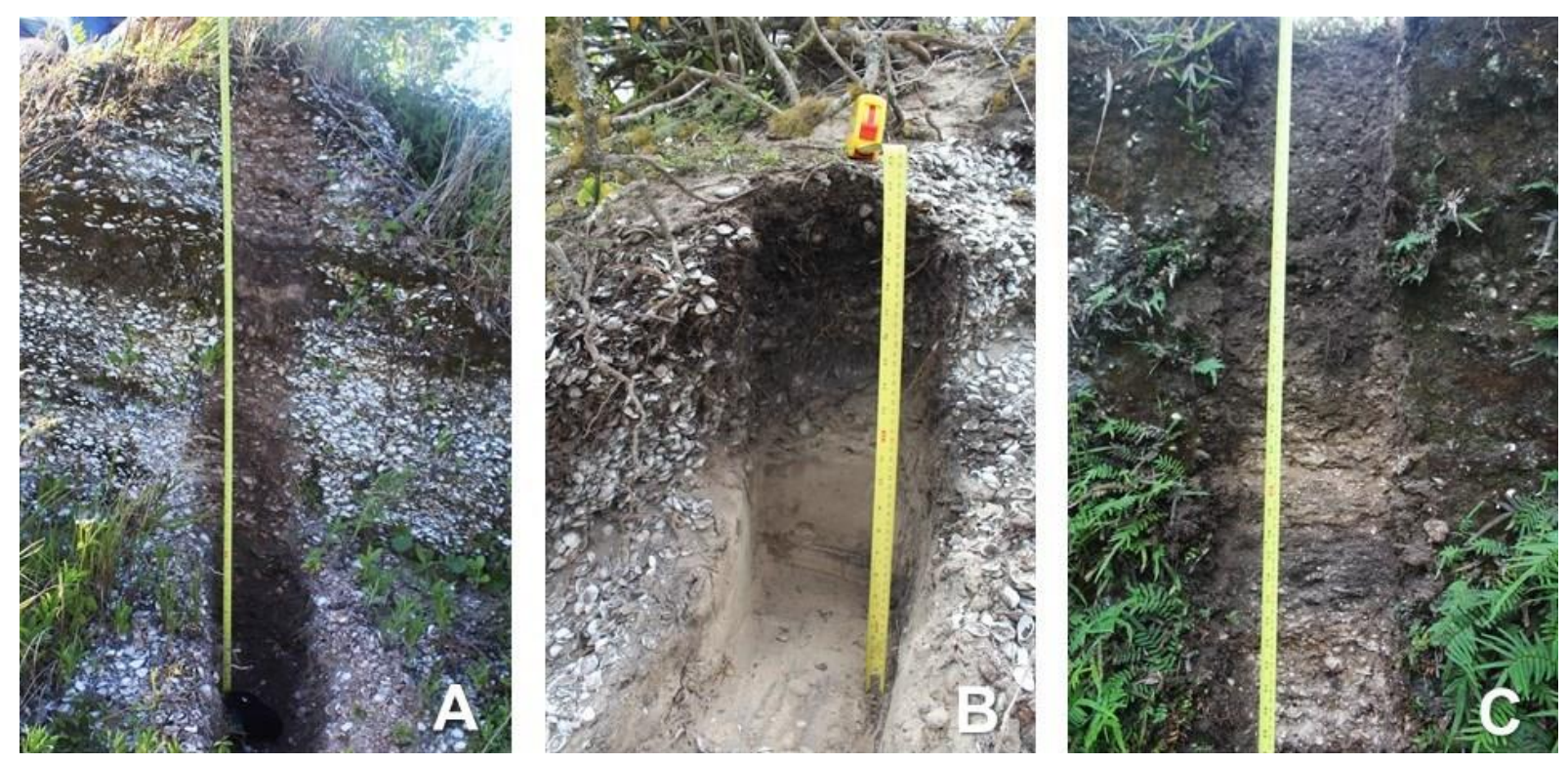

Figura 2. Padrões estratigráficos dos sambaquis da costa centro-sul catarinense, segundo Giannini et al. (2010): A) conchífero (interestratificação entre lâminas de conchas inteiras ou quebradas e sedimentos areno-argilosos pretos): sambaqui Cabeçuda; B) núcleo arenoso (núcleo quartzo-arenoso monticular, maciço, sob capa de areia com conchas): sambaqui Carniça 3; C) montículo ictiológico, no topo da seção (misturas de areia com conchas e ossos queimados, com fragmentos líticos e cerâmicos e carvão): sambaqui Jaboticabeira 2.

Estes três padrões estratigráficos possuem diferentes distribuições no tempo. O padrão conchífero alcança as idades mais antigas, cerca de 7500 anos, no sambaqui Caipora, e perdura até cerca de 1500 anos atrás, quando dá lugar ao padrão depósito ictiológico, em que o aparecimento de um elemento até então inédito - a cerâmica - pode ser atribuído ao contato dos sambaquieiros com populações do grupo Jê, oriundos do planalto (Prous, 1992; Giannini et al., 2005; De Blasis et al., 2007); portanto, o padrão depósito ictiológico encerra a tradição de retrabalhamento de conchas, observada desde as primeiras construções (De Blasis et al., 2007; Bendassoli, 2007; Nishida, 2007; Villagran, 2008, 2012, 2013; Villagran et al., 2009). Já os sambaquis de núcleo arenoso, como o Carniça 3, ocorrem paralelamente à 
construção dos sambaquis do padrão conchífero, até cerca de 4000 anos calibrados antes do presente (cal AP).

Se esta variação de distribuição dos padrões estratigráficos no tempo denota o abandono quase completo do uso de conchas como material construtivo dos sambaquis a partir de aproximadamente 1500 anos AP, a estratigrafia do sambaqui mais estudado da região, o Jaboticabeira 2, indica também, segundo Giannini et al. (2009) e Menezes (2009), o aumento progressivo da presença de conchas quebradas ou moídas, em detrimento das conchas inteiras, o que coincide no tempo com a regressão marinha e o assoreamento lagunar na região. Uma hipótese, apresentada por estes autores, é a de que esta regressão conduziu à redução em área, e ao afastamento, dos bancos de moluscos, o que teria levado primeiro à queda no uso de conchas inteiras e, em seguida, ao abandono das conchas como material construtivo. Hipótese alternativa, mas que não exclui necessariamente a primeira, é a de que a queda progressiva no uso das conchas inteiras deva-se à implantação de condições ecológicas cada vez mais desfavoráveis a Anomolacardia brasiliana, devido à queda de salinidade nas águas lagunares promovida pelo aumento de pluviosidade na região no Holoceno superior, indicado por dados isotópicos de espeleotemas de Santa Catarina (Cruz et al., 2006; Bernal et al., 2016). Relacionado com esta questão, Amaral (2008), Tanaka (2010) e Amaral et al. (2012) sugerem que uma oscilação negativa por volta de 2700 anos AP nas curvas de $\delta^{13} \mathrm{C}$ e $\delta^{18} \mathrm{O}$ de conchas de $A$. brasiliana obtidas por Fornari et al. (2008) possam registrar momento de aumento de pluviosidade na região em escala secular, também detectado nos dados de Cruz et al. (2006).

A questão do aumento do aporte de água doce e a da redução de conexão das lagunas com o mar devem ser discutidas frente ao conhecimento sobre a ecologia de A. brasiliana. Se, por um lado, mecanismos fisiológicos e comportamentais permitem a esta espécie sobreviver a estresses ambientais durante as baixa-mares (e.g. resultantes de choque térmico e/ou dessecação) e as preamares (e.g. choque osmótico), bem como à deficiência de oxigênio dissolvido e à presença de sulfeto de hidrogênio (Hiroki, 1977 apud Boehs et al., 2008), por outro lado, salinidades muito baixas $(<17)$, frequentes na porção mais interior de lagunas com aporte fluvial e estuários, acabam por tornar-se seu principal fator ecológico limitante, a ponto de inviabilizar sua presença (Leonel et al., 1983 apud Boehs et al., 2008). 
A verificação das hipóteses aqui mencionadas demanda detalhamento estratigráfico e cronológico de um número representativo de sambaquis e, também, balizamento por estudos comparativos com depósitos naturais próximos, os quais materializam o preenchimento sedimentar das antigas baías e lagunas, cujo fundo serviu, supostamente, de fonte para as conchas utilizadas pelos sambaquieiros.

É nesse contexto que se insere a proposta de pesquisa desta tese de doutorado. Depósitos paleolagunares e sambaquis de Santa Catarina, abrangem, conjuntamente, o registro da maior parte do Holoceno médio a tardio, com controle cronológico preciso, constituindo importante arquivo de informações paleoambientais, por serem ainda extraídas via estudos sedimentológicos e de tafonomia e composição químico-isotópica das conchas. Assim, o desafio desta tese é apresentar uma interpretação da evolução sedimentar, climática e ambiental, decorrida entre cerca de 7 mil e 1,5 mil anos cal AP, na região costeira centro-sul de Santa Catarina, por meio do registro presente nas conchas de moluscos, especialmente do bivalve Anomalocardia brasiliana, provenientes de depósitos sedimentares naturais e arqueológicos. 


\section{OBJETOS DE ESTUDO}

\section{1 Área de estudo}

2.1.1 Nível relativo do mar, clima e paleoclima

O nível relativo do mar (NRM) máximo admitido na costa do Brasil para o Último Interglacial (120 ka AP) é de $8 \mathrm{~m} \pm 2 \mathrm{~m}$ acima do nível atual (Martin et al. 1988, Suguio et al. 1992), estimado a partir das altitudes de terraços de construção marinha essencialmente arenosos e na datação U/Th de fragmentos de corais neles encontrados no Estado da Bahia (Bernat et al. 1983).

Para o Holoceno, Angulo et al. (2006), em análise crítica de todos os indicadores disponíveis na literatura até então, deduziram declínio suave de NRM após o nível máximo holocênico de 3 a 4 m, alcançado entre 7000 e 5000 anos cal AP.

Na costa centro-sul de Santa Catarina, cerca de 30 datações de indicadores de variação do NRM durante o Holoceno, obtidas por Angulo et al. (1999) em vermetídeos, indicam paleonível máximo de $2,1 \mathrm{~m} \pm 1,0 \mathrm{~m}$ mais alto que o atual, alcançado em 5410 \pm 80 anos AP (5916-5597 anos cal AP) (Angulo e Giannini, 1993; Angulo et al. 2006).

Inserida na Zona Subtropical, a costa centro-sul do Estado de Santa Catarina está sob o limite médio meridional da Zona de Convergência do Atlântico Sul (ZCAS), faixa de nebulosidade que se estende, em orientação NW-SE, desde o sul da região amazônica até a região central do Atlântico Sul.

Há duas importantes fontes para a umidade envolvida na precipitação na região (Cruz et al. 2006, Garreaud et al. 2009). A primeira é o Sistema de Monções da América do Sul (SMAS), responsável por mais de $60 \%$ da precipitação de Santa Catarina (Cruz et al. 2006). Este sistema climático está associado ao desvio rumo SE da Zona de Convergência Intertropical (ZCIT) para a ZCAS, que é intensificado durante o verão (Mendes et al., 2015). A segunda fonte, são as frentes frias, responsáveis pelas chuvas ocorrentes no inverno (cerca de $40 \%$ do total). Não existe assim uma estação seca muito bem definida e, na classificação de Köppen (1948), seu clima é Cfa, ou seja, "subtropical úmido sem estação seca, com verão quente e inverno frio". 
As médias anuais de precipitação pluviométrica, inferidas por Orselli (1986) para a região estudada são de $1250 \mathrm{~mm}$ para Imbituba, com 110 dias de chuva, e $1400 \mathrm{~mm}$ para Laguna, com 120 dias de chuva.

Estudos recentes, baseados sobretudo na relação das razões isotópicas de oxigênio em espeleotemas com a origem das massas de ar úmido, relacionam a variação na intensidade das chuvas no Sul e Sudeste brasileiro ao Sistema de Monções do Atlântico Sul - SMAS (Cruz et al., 2006, Vuille et al. 2012). Segundo esses estudos, o aumento da precipitação anual na região entre Santa Catarina e Rio de Janeiro estaria ligado à intensificação das monções de verão, que por sua vez seriam moduladas, na escala de dezenas de milênios, pelos ciclos de precessão dos equinócios de Milankovitch. Uma das primeiras cavernas cujos espeleotemas permitiram chegar a estas conclusões foi a de Botuverá (Cruz et al., 2006), localizada no centro-norte de Santa Catarina.

Dentro do Holoceno, existiriam outras variações na intensidade da SMAS, correlatas a períodos curtos (poucos séculos) de resfriamento no hemisfério norte, os chamados eventos Bond (Bond et al. 1997). Apesar de controlados por mudanças globais e de serem, portanto, aproximadamente sincrônicos ao largo do planeta, estes eventos possuem respostas climáticas distintas dependendo do hemisfério e da latitude. Assim, numa primeira aproximação, os períodos mais quentes nas médias e altas latitudes do hemisfério norte estariam relacionados com o enfraquecimento do SMAS e, portanto com menor intensidade de chuvas no sul da América do Sul, enquanto os períodos frios (PIG e eventos Bond) seriam de intensificação da SMAS e portanto de aumento das chuvas, não somente as de monções, mas também as ligadas à incursão de massas polares vindas de sul, cujas frentes frias se tornariam então mais atuantes (Cruz et al., 2006). 


\subsubsection{Distribuição dos sistemas deposicionais quaternários}

Quatro sistemas deposicionais quaternários afloram na costa centro-sul catarinense, na região entre Imbituba e Jaguaruna (Figura 3): barreira (ou barrabarreira), planície costeira (ou de cordões), lagunar e eólico (Giannini, 1993, 2002; Giannini et al., 2005, 2007, 2010; Amaral et al., 2012; Fornari et al., 2012).

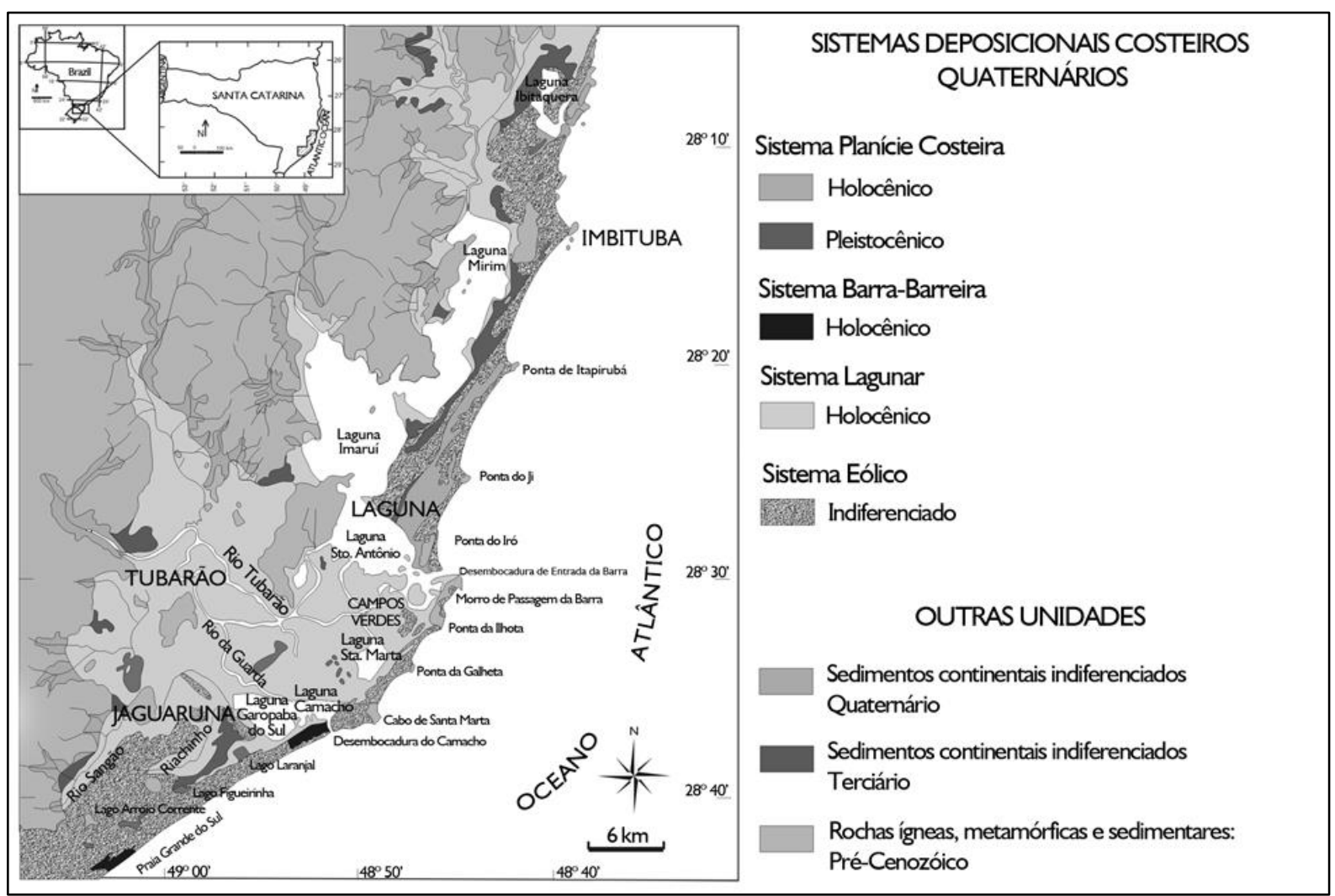

Figura 3. Mapa de sistemas deposicionais do litoral centro-sul catarinense (Giannini et al., 2010).

Segundo Giannini et al. (2010), o sistema barreira consiste numa faixa de sedimentos arenosos holocênicos, com menos de $2 \mathrm{~km}$ de largura e cotas não superiores a $2 \mathrm{~m}$ (exceto nos locais com superimposição de dunas eólicas), que separa laguna de mar aberto a sul de Passagem da Barra (Figura 3) e foi formado inicialmente durante a transgressão holocênica.

O sistema planície costeira, de origem regressiva e marcado pela ausência de corpo lagunar contíguo que a ele se relacione geneticamente, é representado por pelo menos duas gerações, uma pleistocênica, com altitude de mais de $4 \mathrm{~m}$, e outra holocênica, mais baixa, esta a norte de Laguna (Figura 3).

O sistema lagunar holocênico abrange lagunas intercomunicáveis e uma série de lagos residuais de antigos fundos lagunares, os quais integraram complexos de lagunas interligadas durante níveis do mar mais altos que o atual. Este sistema 
deposicional foi formado por dois processos distintos: isolamento parcial do corpo de água por formação de uma barreira arenosa transgressiva (sistema barreira) e afogamento de vales de dissecação preexistentes (incisos no sistema planície costeira pleistocênico). Estes dois processos devem ter ocorrido mais ou menos concomitantes, no âmbito da elevação do NRM holocênico, cujo máximo teria sido atingido provavelmente entre 5700 e 5100 anos AP (Angulo et al., 1999, 2006), ou pouco antes disso; as porções do sistema lagunar formadas por estes dois tipos de processos foram denominadas respectivamente baía-laguna e vale-laguna (Giannini 2002). A baía-laguna abrange três lagunas interconectadas, Garopaba do Sul, Camacho e Santa Marta, e uma série de lagos residuais de antigas lagunas (Figueirinha, Gregório Bento, Laranjal; a vale-laguna ocorre associada às lagoas a norte de Passagem da Barra (Santo Antônio, Imaruí e Mirim) (Giannini, 1993, 2002) e também aos atuais vales de inundação dos rios Sangão e Riachinho (Giannini, 2002; Amaral, 2008; Amaral et al., 2012) (Figura 3).

Este sistema lagunar, com orientação NE-SW, alinha-se na direção dos ventos predominantes. Os corpos de água da baía-laguna são rasos (profundidade máxima de 2,5 $\mathrm{m}$ ), com comprimento total de $9 \mathrm{~km}$ e $6 \mathrm{~km}$ de largura máxima (Fornari et al., 2012). Os corpos lagunares Garopaba do Sul e Camacho separam-se da dinâmica de mar aberto pelo sistema barreira e ocorrem conectados ao mar através da desembocadura lagunar do Camacho. A laguna Santa Marta é conectada àqueles dois corpos lagunares através de um canal interlagunar (rio do Meio) e insere-se entre os promontórios rochosos do Cabo de Santa Marta e da Ponta da Galheta. Os corpos de água do vale-laguna são pouco mais profundos (até $7 \mathrm{~m}$ ), uma vez que em parte herdados de antigas feições erosivas.

A paisagem regional é complementada pelo sistema deposicional eólico, que se superpõe principalmente aos sistemas barreira e planície costeira, mas também ao lagunar nas regiões de Campos Verdes e Garopaba do Sul. Abrange campos de dunas de pelo menos quatro diferentes gerações (Giannini et al., 2007): (geração 1) anterior ou aproximadamente contemporânea ao máximo NRM do último interglacial pleistocênico; (geração 2) predominantemente anterior à máxima inundação holocênica; (geração 3) posterior a esta máxima inundação, e formada essencialmente nos últimos três milênios; e (geração 4) correspondente às dunas eólicas em atividade. 


\subsubsection{Evolução da sedimentação lagunar}

Fornari et al. (2012), com base em atributos sedimentológicos, inclusive taxonomia e tafonomia das conchas, identificaram na porção retro-barreira do sistema lagunar entre Jaguaruna e Laguna (baía-laguna), três associações de fácies que, por sua vez, materializam três fases de evolução geomorfológica (FEG; Figura 4). A sucessão de associações de fácies registra, segundo os autores, a transição de uma baía semiaberta para um sistema lagunar sensu stricto, este ultimamente em franco processo de assoreamento. As mudanças de fácies e paleogeografia teriam sido controladas por variações regionais no NRM, na morfologia antecedente e no suprimento sedimentar.
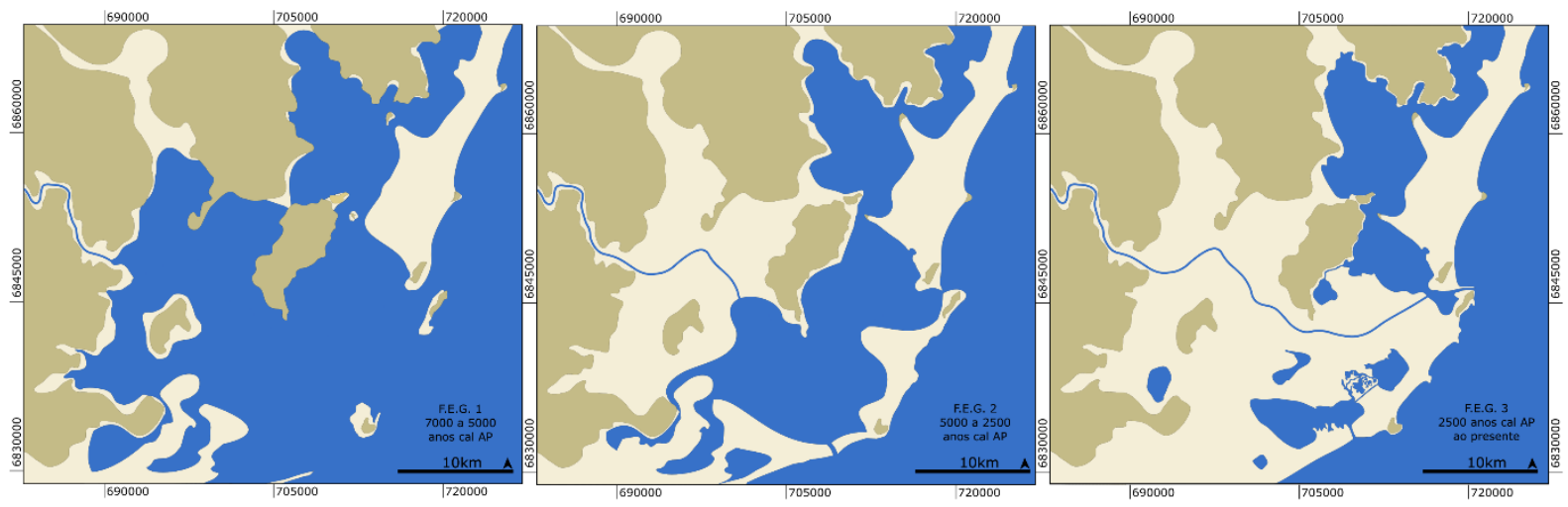

Figura 4. Três fases de evolução reconhecidas para a região, segundo Fornari et al. (2012): FEG 1 (7000 a 5000 anos cal AP); FEG 2 (5000 a 2500 anos cal AP); FEG 3 (2500 anos cal AP ao presente).

A associação de fácies mais antiga, denominada lençol de areia, varia de 1 a 3 $\mathrm{m}$ de espessura; é formada por sedimento arenoso muito fino contendo bioclastos de moluscos, crustáceos e equinodermos dispersos na matriz; estes são caoticamente orientados, em diversas classes de tamanho (entre 2 e $25 \mathrm{~mm}$ ), dominantemente desarticulados, com poucos exemplares articulados fechados $(<3 \%)$ e densa concentração de conchas fragmentadas (40\%). A associação faunística é dominada por espécies características de antepraia superior e baía, representadas pelos moluscos Tellina sp., A. brasiliana, Diplodonta punctata, Divaricella quadrisulcata, Bulla striata, Olivancellaria urceus e Olivella sp. e, pelos equinodermos Encope emarginata e Litechinus variegatus; mas inclui também elementos de substrato rochoso em promontórios de mar aberto ou no interior de baías, como crustáceos do gênero Ballanus. Com idades entre 8000 e 5700 anos atrás, esta primeira associação de fácies contém o registro da transgressão marinha holocênica e a FEG correspondente foi marcada pela formação de baías em contexto de subida de NRM. 
A segunda associação de fácies, a lagunar, com cerca de $1 \mathrm{~m}$ de espessura, ocorre imediatamente sobre o lençol de areia transgressivo, em passagem bem definida. Os depósitos desta associação, dominados por areia lamosa, diferenciamse dos anteriores pela tendência granulométrica de afinamento ascendente, pela redução na diversidade e representatividade de moluscos marinhos e pela sua menor fragmentação; dominam espécimes articulados, fechados e in situ, sobretudo conchas bem preservadas de $A$. brasiliana e Crassostrea rhizophorae, cujos habitats caracterizam-se por significativo aporte de água marinha (salinidade acima de 15 a 17), com pouca ação de ondas. Esta associação de fácies foi depositada entre 5000 anos cal AP e 2500 anos cal AP, durante a FEG 2, caracterizada pelo início da descida do NRM e pela formação de corpos aquosos lagunares restritos pela barreira arenosa a leste; a sedimentação passou a ser condicionada por ondas de ventos locais, com pista reduzida e lâmina de água rasa (poucos metros), portanto com menor energia que a da associação de fácies anterior (Fornari et al., 2012).

A terceira associação de fácies, mais nova que 2500 anos AP, com até $80 \mathrm{~cm}$ de espessura, caracteriza-se pela substituição dos depósitos conchíferos por depósitos lamosos, ou mesmo turfosos, com detritos vegetais, decorrência da expansão das marismas e brejos de supramaré, do aumento relativo do fluxo fluvial para o interior da laguna e do avanço de dunas eólicas sobre a planície retrobarreira (Fornari et al., 2012) que caracterizam a FEG 3. A continuação do declínio do NRM e a restrição das desembocaduras, como Camacho, reduziu ainda mais a influência das águas marinhas sobre o sistema deposicional lagunar. 


\subsubsection{Distribuição dos sambaquis}

Os sambaquis da região centro-sul de Santa Catarina podem ser agrupados, conforme Giannini et al. (2010), em quatro setores geográficos principais (Figura 5): um interior, associado ao delta lagunar do rio Tubarão, e três externos, associados aos pontões costeiros e à barreira arenosa holocênica e respectiva margem lagunar retrobarreira (setores nordeste, central e sudoeste).

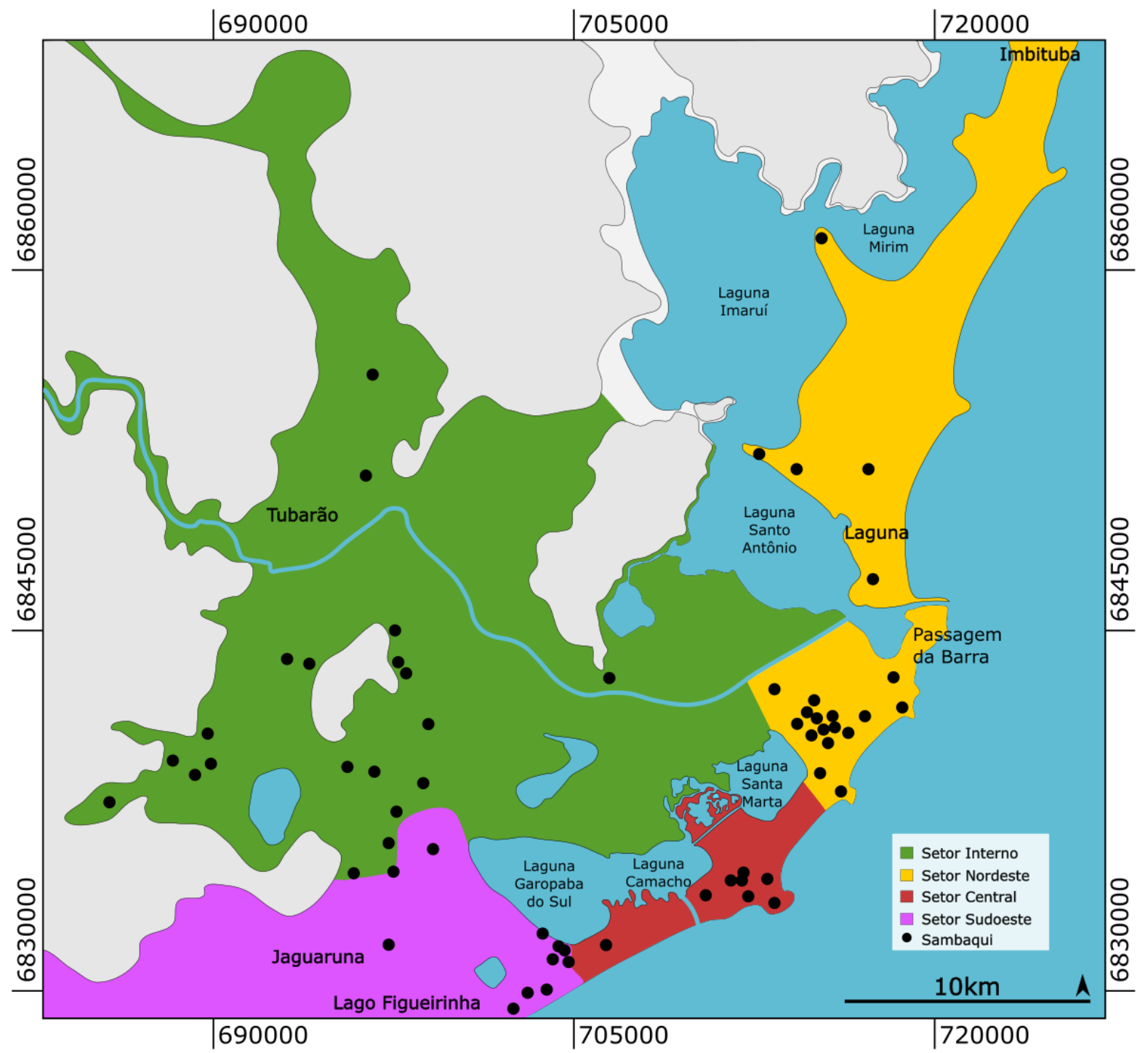

Figura 5. Mapa de distribuição espacial dos sambaquis da região entre Imbituba e Jaguaruna, de acordo com quatro setores principais (Giannini et al., 2010). 
Do ponto de vista do contexto geológico-geomorfológico, os sambaquis desta região (Figura 6) distribuem-se nas cinco situações seguintes, detalhadas pela Figura 3: 1) pontas costeiras e costões rochosos de mar aberto, inclusive paleodunas sobre eles e paleotômbolos na sua sombra hidrodinâmica; 2) paleopontais de retrobarreira, na extensão ao continente dos paleotômbolos do setor nordeste; 3) morros testemunho e paleodunas da geração eólica 2, próximos da margem lagunar, no setor sudoeste; 4) regiões planas do sistema barreira, incluindo margem de retrobarreira, sobretudo nas concentrações sudoeste e central, onde os sítios se dispõem de modo mais espaçado e em distribuição mais linear, sub-paralela à costa; 5) morros testemunhos do embasamento pré-cenozoico, em meio ao delta e/ou à paleobaía lagunar por ele assoreada do setor interno.
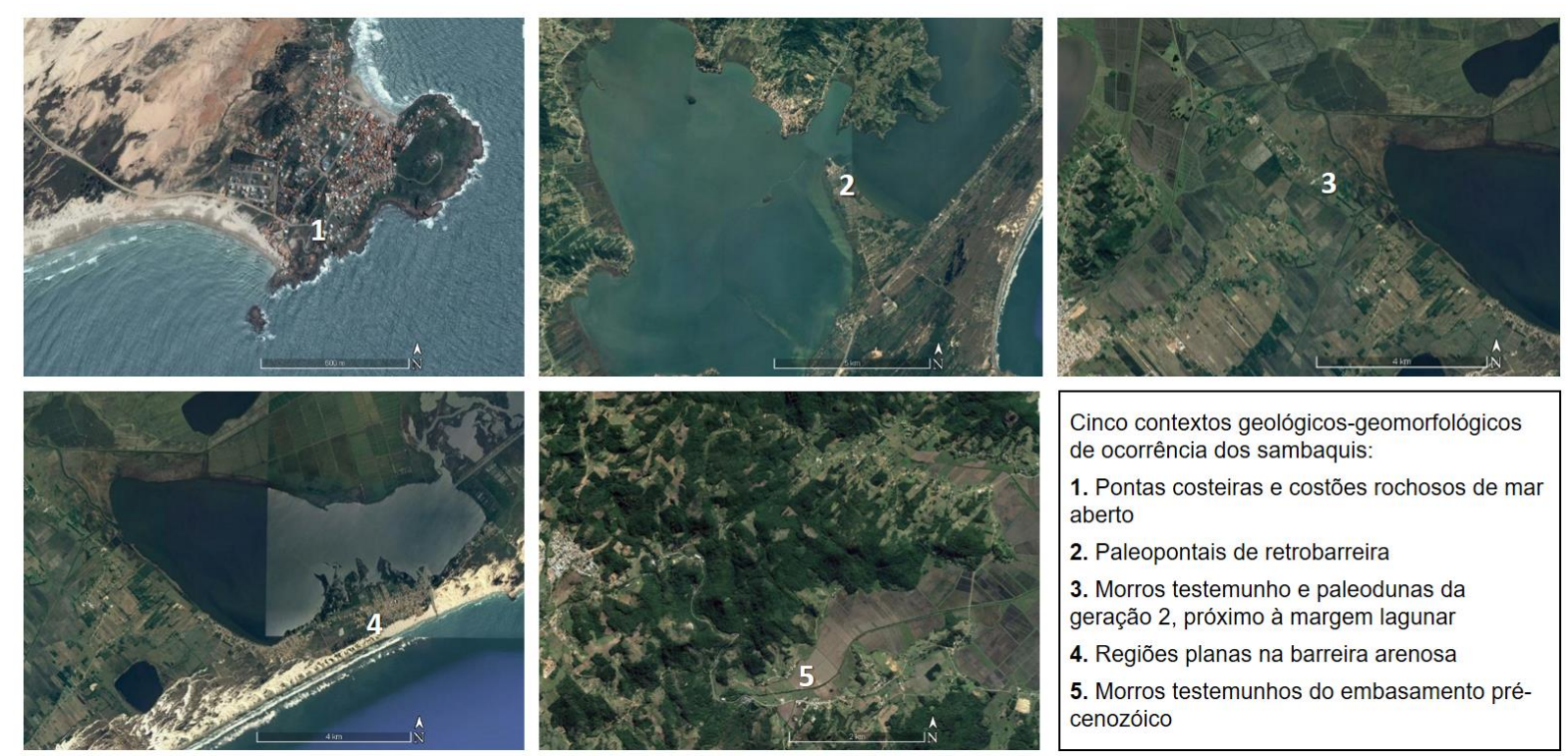

Cinco contextos geológicos-geomorfológicos de ocorrência dos sambaquis:

1. Pontas costeiras e costões rochosos de mar aberto

2. Paleopontais de retrobarreira

3. Morros testemunho e paleodunas da geração 2, próximo à margem lagunar

4. Regiões planas na barreira arenosa

5. Morros testemunhos do embasamento précenozóico

Figura 6. Contextos geológicos-geomorfológicos de distribuição dos sambaquis, baseados em Giannini et al. (2010).

\subsubsection{Evolução da ocupação sambaquieira}

Quatro histogramas de distribuição de frequências de sambaquis da área quanto à idade (máxima) de construção, obtidos por Giannini et al. (2010), permitiu aos autores observar quatro fases de ocupação sambaquieira (FOS), delimitadas pela ausência ou diminuição na frequência de sítios. A ocupação humana acompanhou as três fases de evolução geomorfológica (FEG) da região, reconhecidas por Fornari et al. (2012). As fases de ocupação sambaquieira e sua contextualização em relação à evolução geomorfológica regional estão ilustradas pelas figuras 7 e 8 . 
A FOS 1 estendeu-se de 7400 anos cal AP - início da ocupação na região até 5500 anos cal AP, intervalo aproximadamente correspondente à FEG 1, época em que o nível relativo do mar (NRM) chegou a 2,1 $\pm 1,0 \mathrm{~m}$ mais alto que o atual. É caracterizada pela ocorrência de um pequeno número de sambaquis de composição conchífera (tipo 1), restritos principalmente às encostas da serra que margeava uma grande baía sem influência de água doce e sujeita a ondulações marinhas, semifechada por um conjunto de ilhas e/ou tômbolos, e de sambaquis de núcleo arenoso (tipo 2), na ponta rochosa de Santa Marta (Giannini et al., 2010).

A FOS 2 compreende-se entre 5500 anos cal AP e 4000 anos cal AP; seu começo coincide de modo aproximado com início da FEG 2, quando o NRM passou a cair, reduzindo a área da paleobaía e levando à formação de uma grande laguna. Nesta fase, observa-se a intensificação da ocupação sambaquieira, seja pela migração para o centro da laguna, ao ritmo do assoreamento lagunar centrípeto, seja pela ocupação da barreira arenosa transgressiva, então recém-estabilizada. A proporção entre sítios de tipos estratigráfico conchífero (1) e de núcleo arenoso (2), outrora díspar, é igualada (Giannini et al., 2010).

A FOS 3 estende-se de 4000 anos cal AP até aproximadamente 1500 anos cal AP, compreendendo partes da FEG 2 e da FEG 3. Representa o auge da ocupação sambaquieira na região, com a construção massiva de sítios do padrão estratigráfico conchífero (tipo 1). É marcada pela concentração dos sambaquis em dois setores de retrobarreira em franca progradação: junto ao paleotômbolo do cabo de Santa Marta e na planície de cordões lagunares de Campos Verdes (Giannini et al., 2010).

A FOS 4 corresponde à ocupação mais recente da área, cuja idade máxima dos depósitos é de aproximadamente 1700 anos cal AP (Giannini et al., 2010), e insere-se na FEG 3, quando o brejo lagunar de supramaré teve grande expansão. Associa-se a esta fase a alteração de padrão estratigráfico para o tipo 3, ictiológico, onde as conchas perdem importância como material construtivo. 


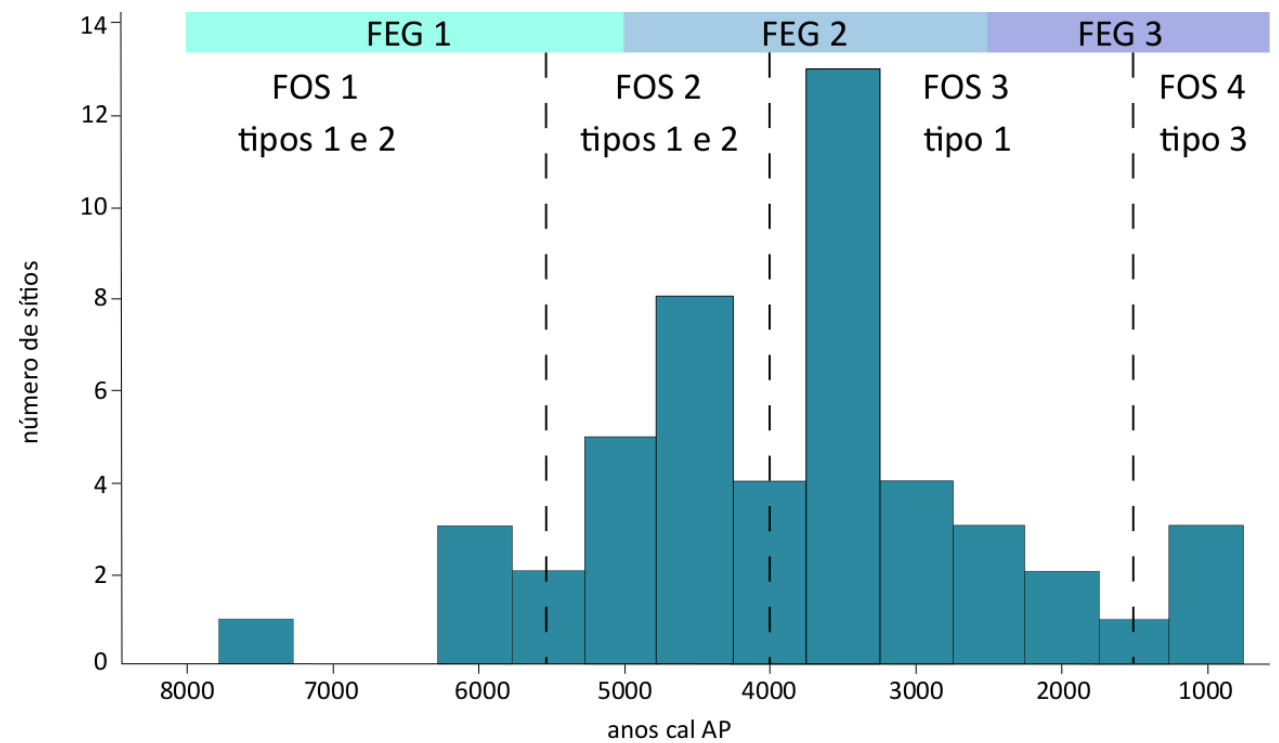

Figura 7. Histograma de distribuição de frequências de idades máximas por sambaqui. Idades referem-se a datações cal ${ }^{14} \mathrm{C}$ (conchas, carvão e ossos humanos). As linhas pontilhadas delimitam as fases de ocupação sambaquieira (FOS) em relação às fases de evolução geomorfológica (FEG) e, dentro de cada intervalo estão citados os tipos estratigráficos mais comuns (tipos 1, 2 e 3) (baseado em Giannini et al., 2010 e em Fornari et al., 2012).

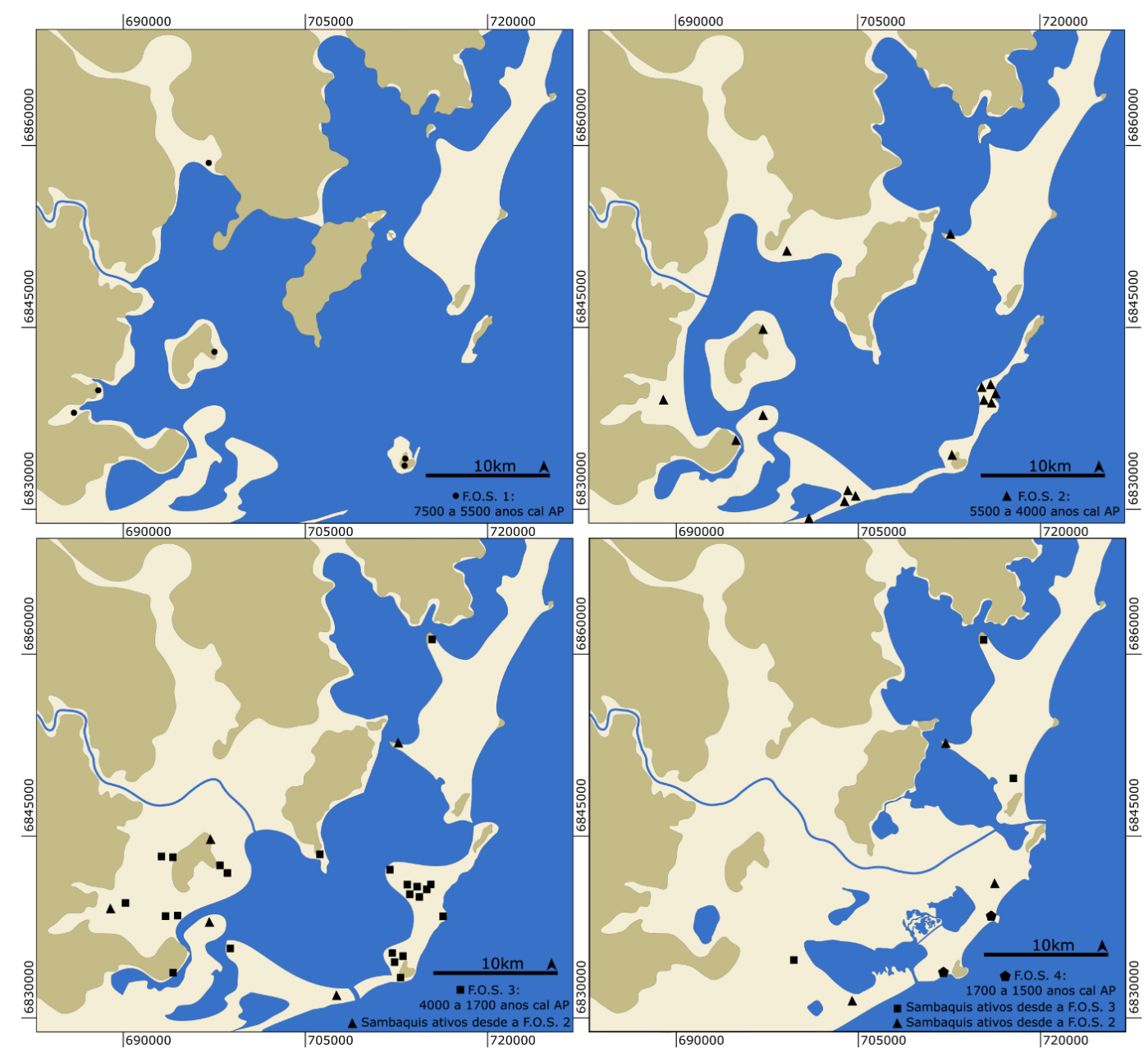

Figura 8. Fases de ocupação sambaquieira (F.O.S.) e sua contextualização em relação à evolução geomorfológica da região, que passou de uma grande baía a um sistema de lagunas intercomunicáveis (adaptado de Giannini et al., 2010). 


\subsubsection{Os depósitos analisados}

Os depósitos analisados nessa tese compreendem os sambaquis Cabeçuda (CB), Carniça $1(\mathrm{CN})$, Carniça $3(\mathrm{CC})$, Caipora (CP), Garopaba do Sul (GS), Jaboticabeira 1 (JC), Jaboticabeira 2 (JB), Perrixil (PX) e Santa Marta 2 (SM) e os terrenos de paleolagunas ou paleobaías próximos a cinco destes sambaquis: Caipora (CPL), Carniça 1 (CNL), Garopaba do Sul (GSL), Jaboticabeira 2 (JBL) e Perrixil (PXL) (Figura 9).

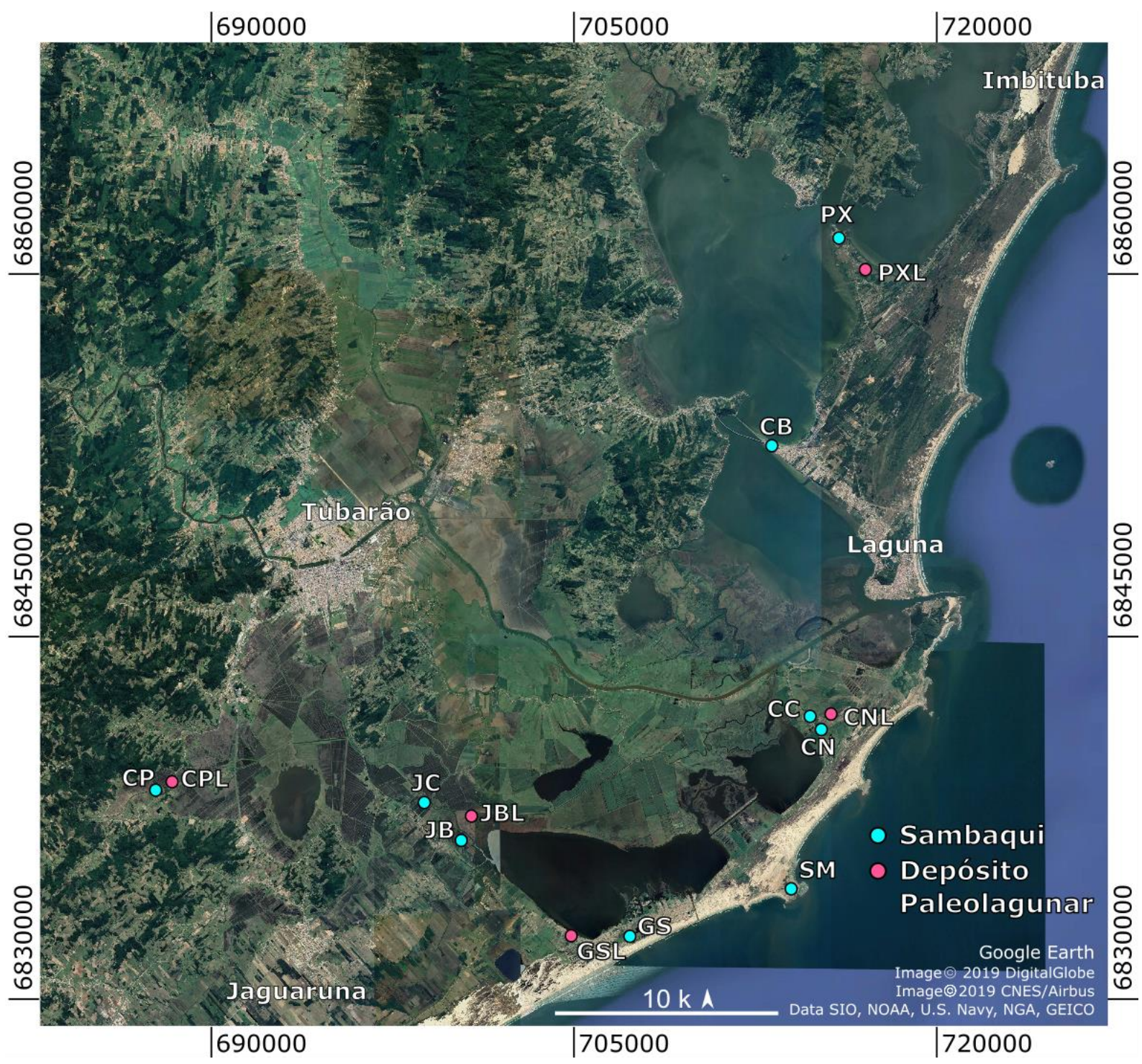

Figura 9. Imagem de satélite da costa centro-sul de Santa Catarina com destaque para os depósitos analisados. Imagem extraída do Google Earth.

A seguir, apresenta-se uma síntese de cada um dos depósitos arqueológicos analisados com respeito à sua localização/setor, idade, geometria, tamanho e características principais, referenciada por pesquisas arqueológicas e sedimentológicas realizadas nesta região e nestes depósitos (Fish et al., 2000; 
Gaspar, 2002; Karl, 2000; Lessa e Medeiros, 2001; DeBlasis et al., 1998, 2007; Villagran, 2008; Assunção, 2010; Giannini et al., 2010; Villagran, 2012).

A sigla de cada sítio arqueológico, empregada neste trabalho, e seu respectivo código no Cadastro Nacional de Sítios Arqueológicos (CNSA) encontram-se entre parênteses, sequencialmente ao nome do sambaqui. Dos sítios em análise, apenas 0 Caipora ainda não possui o cadastro no CNSA.

\section{Sambaqui Cabeçuda (CNSA: SC00709)}

O sambaqui Cabeçuda (22J 712543/6852168; Figura 10) localiza-se entre as lagunas Santo Antônio e Imaruí, no setor nordeste (Giannini et al. 2010; Figura 5), município de Laguna. Possui uma datação obtida entre 2 e $3 \mathrm{~m}$ de profundidade, coincidindo com a primeira concentração de esqueletos humanos, que forneceu idade de $4120 \pm 220$ AP (Putzer, 1957 apud Lessa e Medeiros, 2001).

Até 1928, este sítio encontrava-se praticamente intacto. Contudo, em decorrência da intensa exploração do seu material conchífero para fabricação de cal e uso como material de aterro e pavimentação (Lessa e Medeiros, 2001), perdeu provavelmente maior parte de seu volume; atualmente, possui $60 \mathrm{~m}$ de comprimento por $15 \mathrm{~m}$ de largura e $4 \mathrm{~m}$ de altura (Assunção, 2010).

É composto, majoritariamente, por conchas de $A$. brasiliana, lentes contendo ossos de peixes, de aves e de pequenos mamíferos, carvões e pequenos blocos de granito e diabásio (Figura $10 \mathrm{~A}$ ). É interpretado como área de habitação dos sambaquieiros (Lessa e Medeiros, 2001), com a presença de oficina lítica na área desse sambaqui (Figura 10 B).
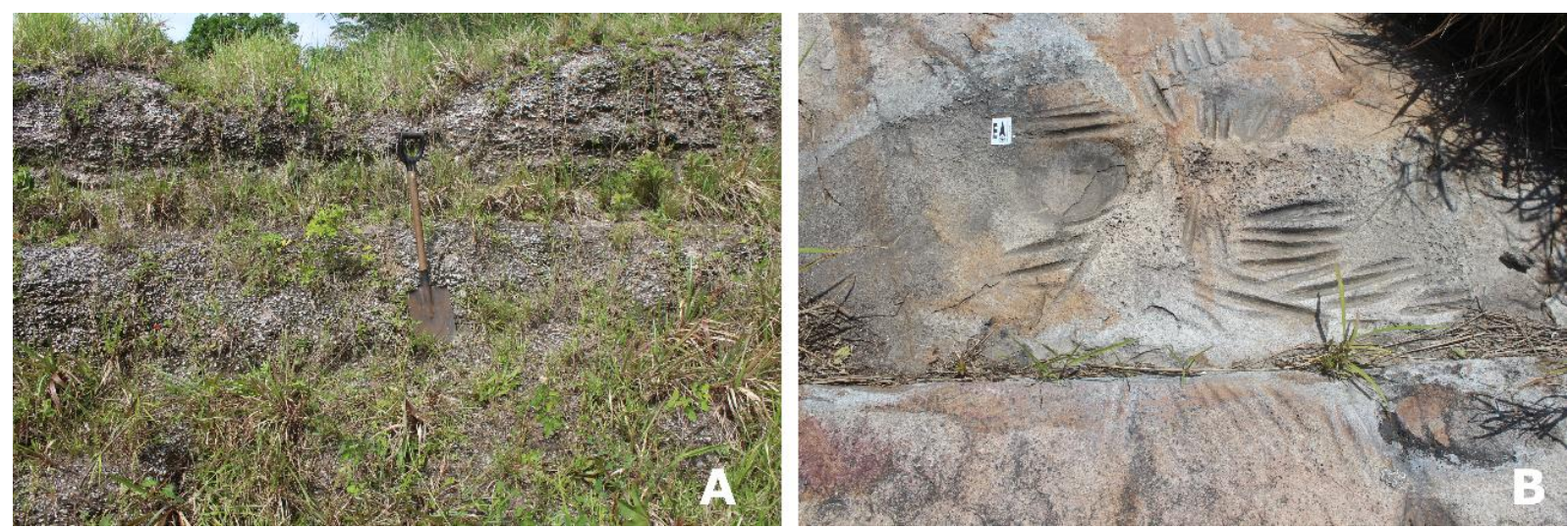

Figura 10. Sambaqui Cabeçuda. A) Seção exposta durante a exploração comercial de cal. B) Oficina lítica, em planta, localizada na área do sambaqui Cabeçuda. 


\section{Sambaqui Carniça 1 (CNSA: SC00712)}

Localizado no bairro de Campos Verdes, município de Laguna, o sambaqui Carniça 1 (22J 713861/6840905; Figura 11) está implantado sobre substrato arenoso de cordões lagunares (Tanaka, 2010), no setor nordeste (Figura 5), e é datado entre 3970 anos cal. AP e 1830 anos cal AP (Giannini et al. 2010).

Bastante devastado pela exploração comercial do calcário, este sambaqui, que, possivelmente, foi o maior da região, atingindo cerca de $60 \mathrm{~m}$ de altura, de acordo com relatos de locais, atualmente mede $400 \mathrm{~m}$ de comprimento, $70 \mathrm{~m}$ de largura e $30 \mathrm{~m}$ de altura (Assunção, 2010). Em algumas seções, apresenta intercalação de conchas e de sedimentos areno-argilosos cinza escuro com boa quantidade de carvão e de fauna queimada; em outras, camadas conchíferas homogêneas de grande (vários metros) espessura. Restos de ossos humanos são encontrados, articulados, nas seções, e, também, retrabalhados e distribuídos pela superfície do sítio. A malacofauna é composta, principalmente, por conchas de A. brasiliana, Lucina, Ostrea e Thais (Assunção, 2010).

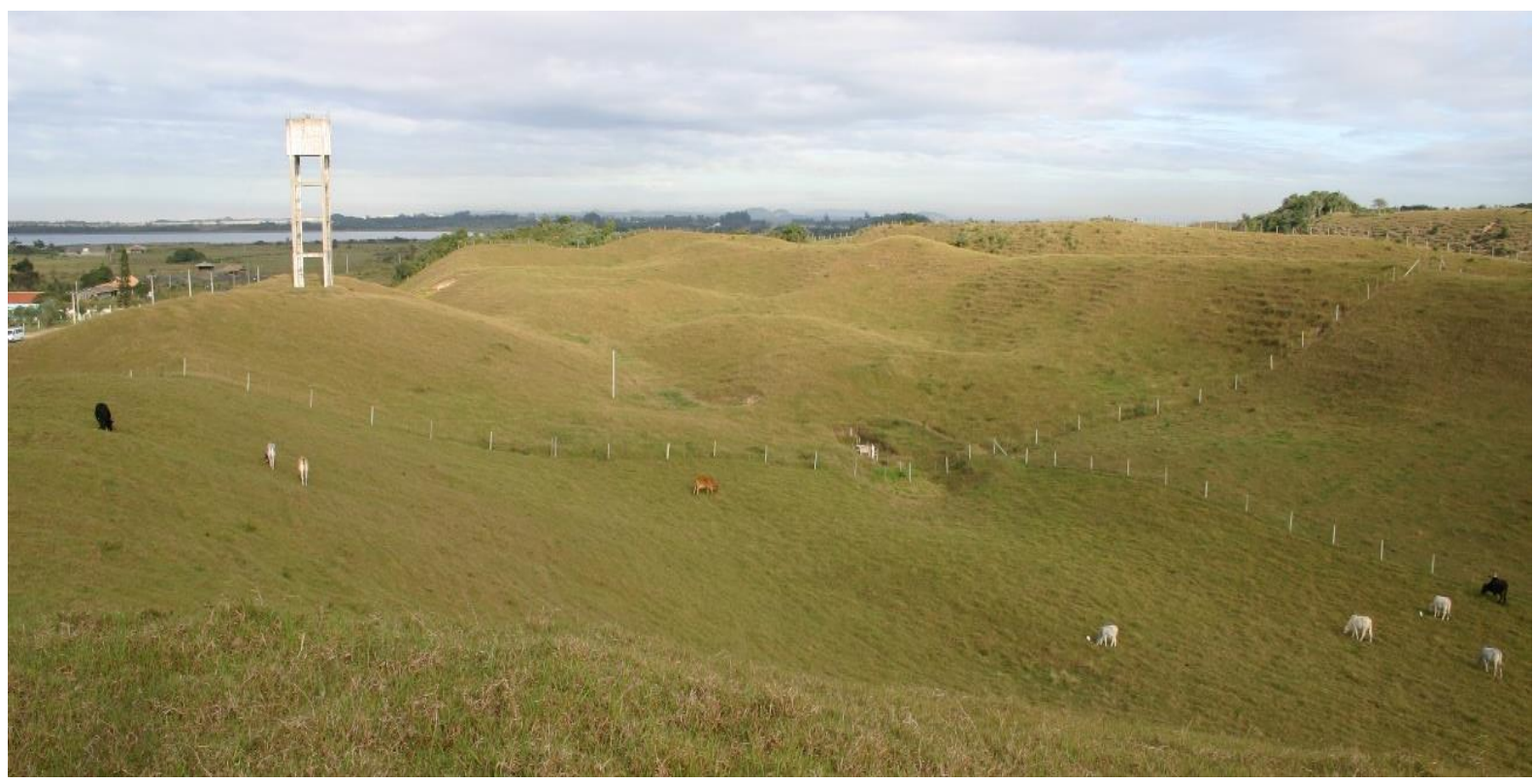

Figura 11. Sambaqui Carniça 1, em visada rumo SW (laguna Santa Marta, ao fundo). Foto: P.C.F. Giannini. 


\section{Sambaqui Carniça 3 (CNSA: SC00714)}

Também localizado no bairro de Campos Verdes, município de Laguna, o sítio Carniça 3 (22J 714541/6840353; Figura 12) é um típico sambaqui do setor externo (Figura 5), em paleopontal lagunar (Giannini et al., 2010). Possui uma única datação, de 3810-3360 anos cal. AP, proveniente de amostra de A. brasiliana coletada no topo (Villagran, 2012), o que permite situá-lo na fase 3 de ocupação sambaquieira regional (4000-1700 anos cal. AP) (Giannini et al., 2010).

De forma alongada norte-sul, tem aproximadamente $40 \mathrm{~m}$ de comprimento, $30 \mathrm{~m}$ de largura e $5 \mathrm{~m}$ de altura. Sua estratigrafia é composta por uma camada de aproximadamente $35 \mathrm{~cm}$ de conchas (majoritariamente $A$. brasiliana) associadas a sedimento arenoso-lamoso cinza escuro, com matéria orgânica, por vezes concrecionado, que cobre um corpo monticular arenoso (Assunção, 2010; Tanaka, 2010).

Por apresentar escasso valor econômico, relacionado à alta quantidade de areia misturada às conchas, este sambaqui salvou-se da exploração comercial e, de acordo com Rohr (1984), em 1975, o sítio encontrava-se intacto, ainda que localizado próximo às caieiras do vizinho sambaqui Carniça 1.

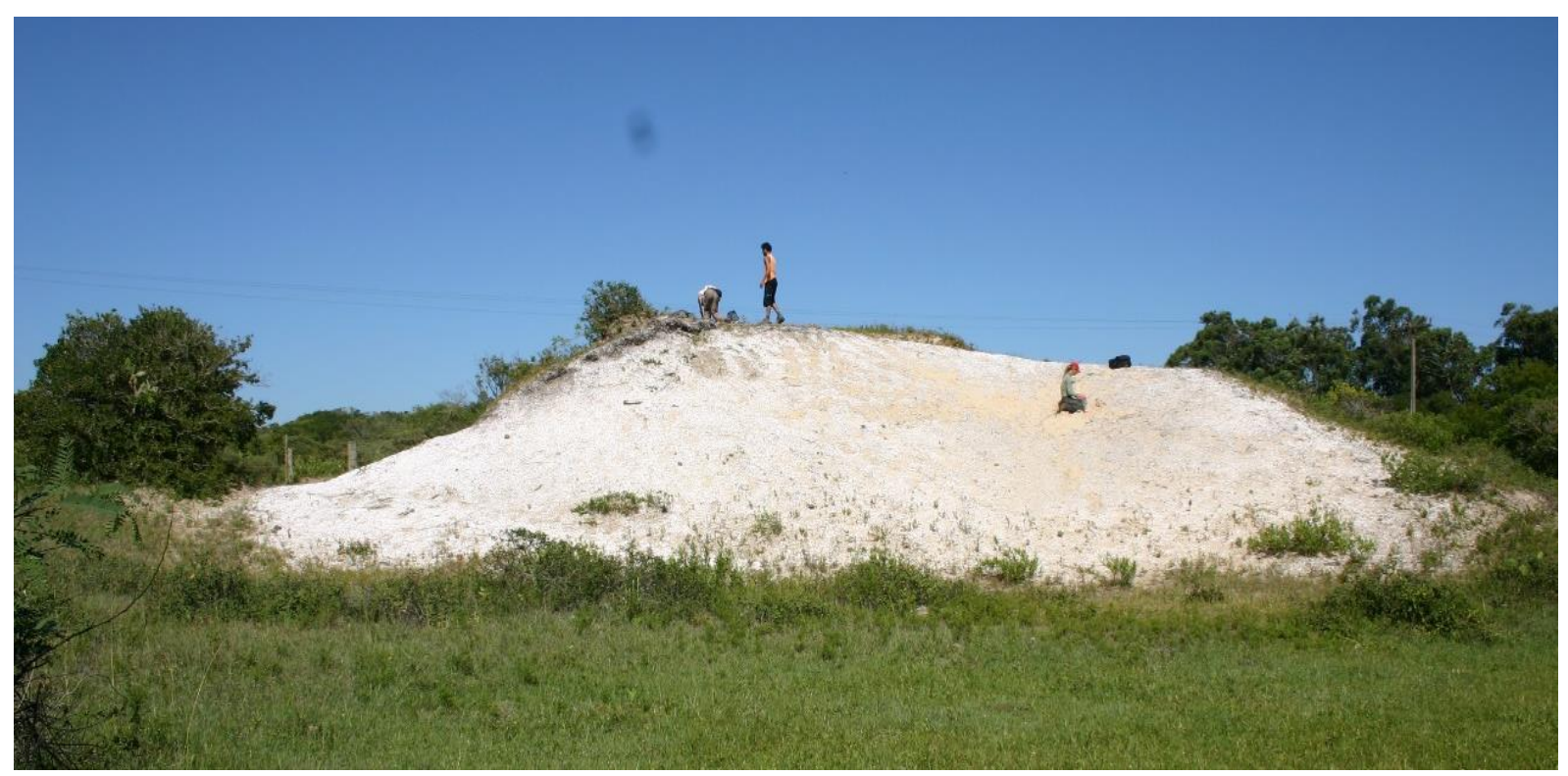

Figura 12. Sambaqui Carniça 3, visto de NE. Foto: P.C.F. Giannini. 


\section{Sambaqui Caipora}

Localizado no setor interno (Giannini et al., 2010; Figura 13), o sítio Caipora (22J 685919/6838066; Figura 9) encontra-se implantado sobre lajedo granítico residual em meio a paleobaía, junto à margem sul do leito retificado do rio Caipora, a aproximadamente $16 \mathrm{~km}$ da atual linha de costa (Villagran, 2012). O terreno do sítio é propriedade particular rural de Pedro Fraganini, no bairro São Gabriel, município de Treze de Maio (Assunção, 2010).

Com idades entre 7570 e 7320 anos cal. AP, na base, e entre 6280 e 5950 anos cal. AP, no topo, este sambaqui pertence à fase 1 de ocupação (7500-5500 anos cal. AP) e é o mais antigo de Santa Catarina (Villagran, 2012).

Possui formato monticular e base arredondada e mede cerca de $25 \mathrm{~m}$ de comprimento, 20m de largura e $3 \mathrm{~m}$ de altura (Assunção, 2010).

Villagran (2012) reconheceu quatro arqueofácies no sambaqui Caipora, da base para o topo: 1) camada onde o componente terrígeno supera o de conchas, junto ao único sepultamento humano identificado e próximo ao contato com o embasamento granítico; 2) areia lamosa preta; 3) conchas inteiras de moluscos misturadas com fragmentos de conchas de tamanhos diversos, onde predominam restos de Ostrea sp., com proporção subordinada de conchas de $A$. brasiliana e outros moluscos, além de fragmentos líticos; 4) fragmentos de conchas de diversas espécies, cuja assembleia faunística assemelha-se à da arqueofácies subjacente, associados a fragmentos de ossos de peixes.

A análise granulométrica e microscópica comparativa entre a fração terrígena da arqueofácies 1 do sambaqui e a fácies $A$ ( $1 \mathrm{~m}$ de profundidade) da paleolaguna adjacente permitiu à Villagran (2012) interpretar origem coluvionar (e não palelagunar) para os sedimentos desta arqueofácies.

A análise petrográfica das lâminas obtidas nas arqueofácies 3 e 4 e na transição das arqueofácies 2 e 3 mostrou que a fração grossa, em todos os casos, é composta por conchas, grãos de quartzo, feldspato e fragmentos líticos e ósseos, com distribuição espacial aleatória na arqueofácies 3 , e trama sub-horizontal das conchas na 3 e 4 . 


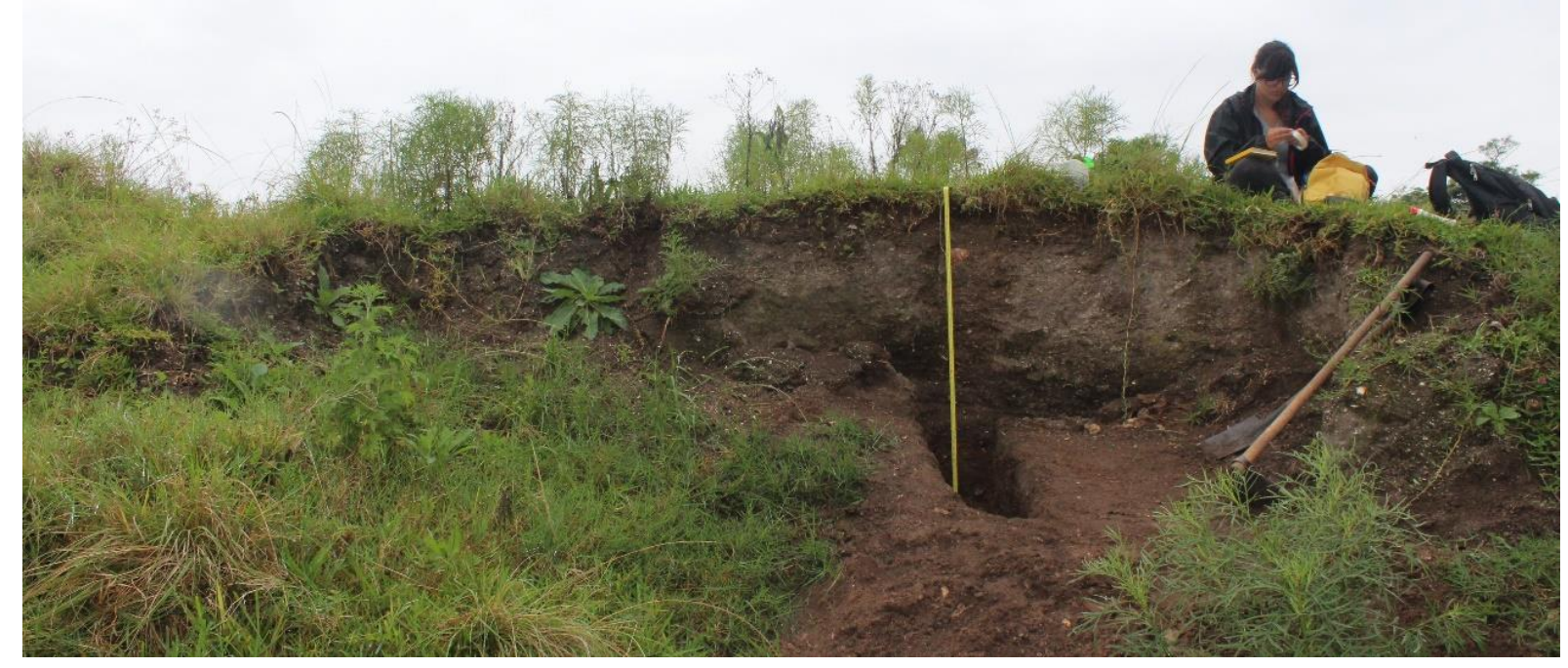

Figura 13. Sambaqui Caipora.

\section{Sambaqui Garopaba do Sul (CNSA: SC00676)}

Assentado sobre a barra-barreira, no setor central (DeBlasis et al., 2007, Giannini et al., 2010, Figura 14), o sambaqui Garopaba do Sul 1 (22J 705944/6831868; Figura 10) possui duração que vai de 4110 a 2795 anos cal. AP (DeBlasis et al., 2007).

Intensamente explorado para extração de calcário no passado, possui hoje $400 \mathrm{~m}$ de comprimento, $400 \mathrm{~m}$ de largura e $22 \mathrm{~m}$ de altura.

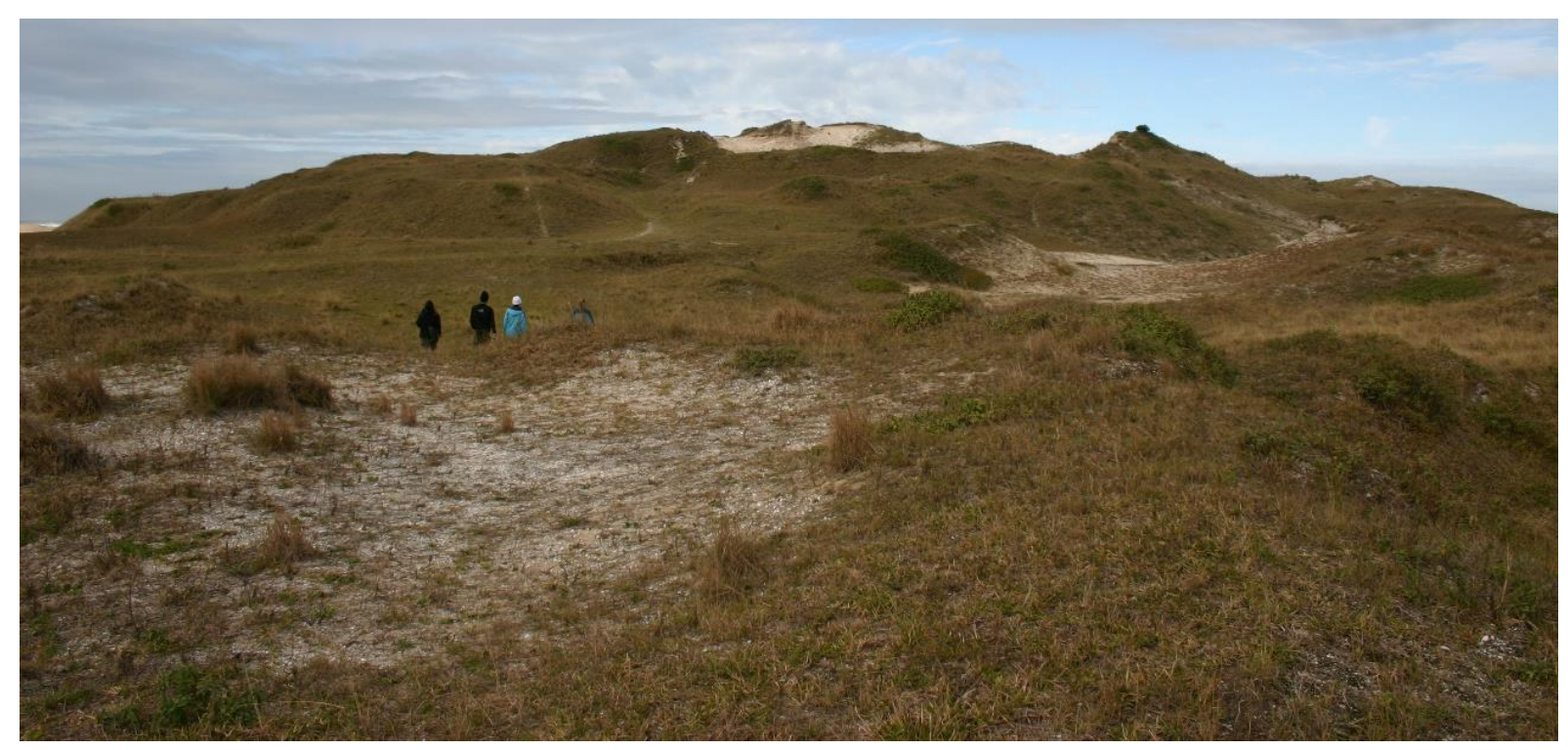

Figura 14. Sambaqui Garopaba do Sul, visto de NW. Foto: P.C.F. Giannini. 


\section{Sambaqui Jaboticabeira 1 (CNSA: SC00650)}

Assentado parte sobre morrote testemunho do embasamento cristalino na paleobaía lagunar, parte sobre paleodunas da geração 2, o sambaqui Jaboticabeira 1 (22J 697350/6837658; Figura 15) localiza-se no município de Jaguaruna, no limite entre os setores interno e externo (Figura 5) e sua deposição abrange tanto a fase 2 (5500-4000 anos cal. AP) como a fase 3 (4000-1700 anos cal. AP) de ocupação da região (Giannini et al., 2010).

Datado entre 4850-4430 anos cal. AP, na base, e 2750-2130 anos cal. AP, próximo ao topo atual (Villagran, 2012), apresenta 400m de comprimento, 150m de largura e $7 \mathrm{~m}$ de altura (Assunção, 2010).

O início da construção deste sambaqui precede ao sítio mais estudado da região, o Jaboticabeira 2. Durante o início da ocupação do local, com NRM cerca de $2 \mathrm{~m}$ mais alto, o sítio localizava-se provavelmente sobre um istmo arenoso fixado no morrote testemunho. Os dois sambaquis de Jaboticabeira foram contemporâneos por mais de mil anos, sendo o Jaboticabeira 1 abandonado quando a margem da paleobaía lagunar ainda se encontrava próxima (Villagran, 2012).

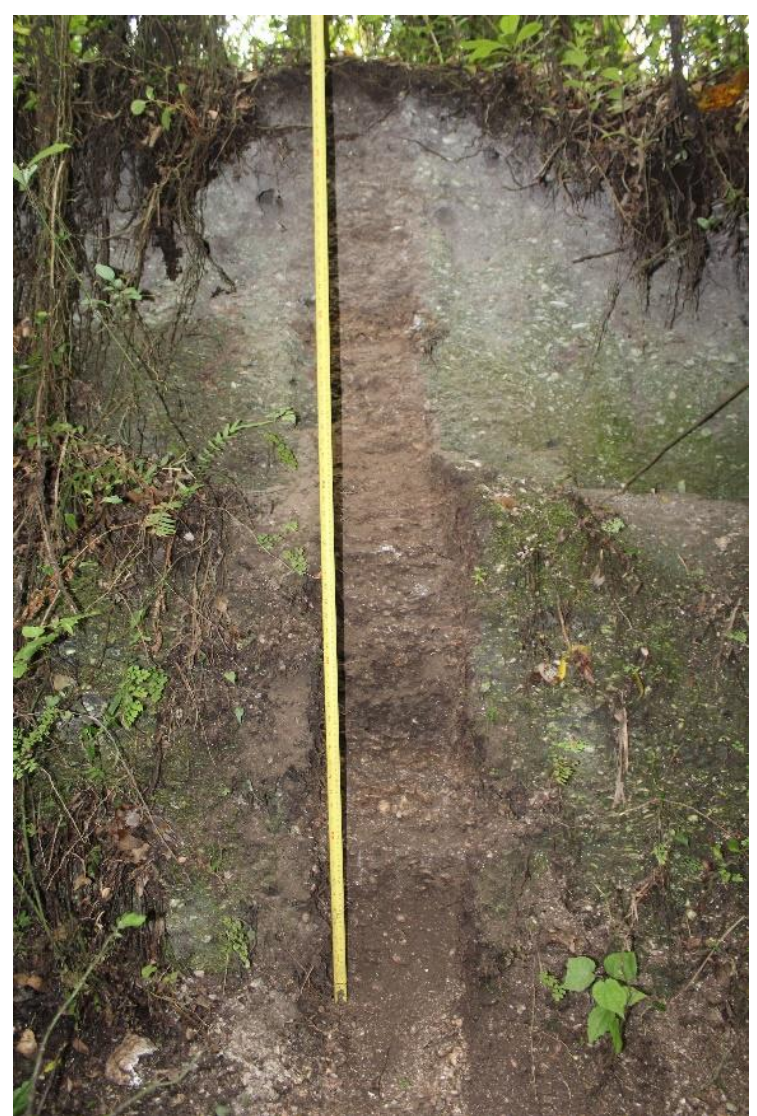

Figura 15. Sambaqui Jaboticabeira 1 


\section{Sambaqui Jaboticabeira 2 (CNSA: SC00651)}

Localizado no município de Jaguaruna, no setor sudoeste (Giannini et al., 2010, Figura 16), o sambaqui Jaboticabeira 2 (22J 699448/6835605; Figura 12), o mais estudado da região, teve o início da sua construção por volta de 3209-2779 anos cal. AP e perdurou por mais de mil anos, sendo finalizado em torno de 1360-1280 anos cal. AP.

Com $350 \mathrm{~m}$ de comprimento, 150m de largura e 10m de altura (Villagran, 2008), sua utilização é interpretada como espaço de atividade ligadas a ritos funerários devido à grande quantidade de sepultamentos humanos encontrada (total estimado de 43.000 sepultamentos) (Fish et al., 2000; Karl, 2000; Gaspar, 2002; Assunção, 2010).

Nos perfis estratigráficos do sítio, observam-se três camadas estratificadas, da base para o topo: conchas intercaladas com estratos delgados de sedimentos pretos; conchas concrecionadas diageneticamente; e sedimentos pretos de espessura decimétrica a métrica (Villagran, 2008).

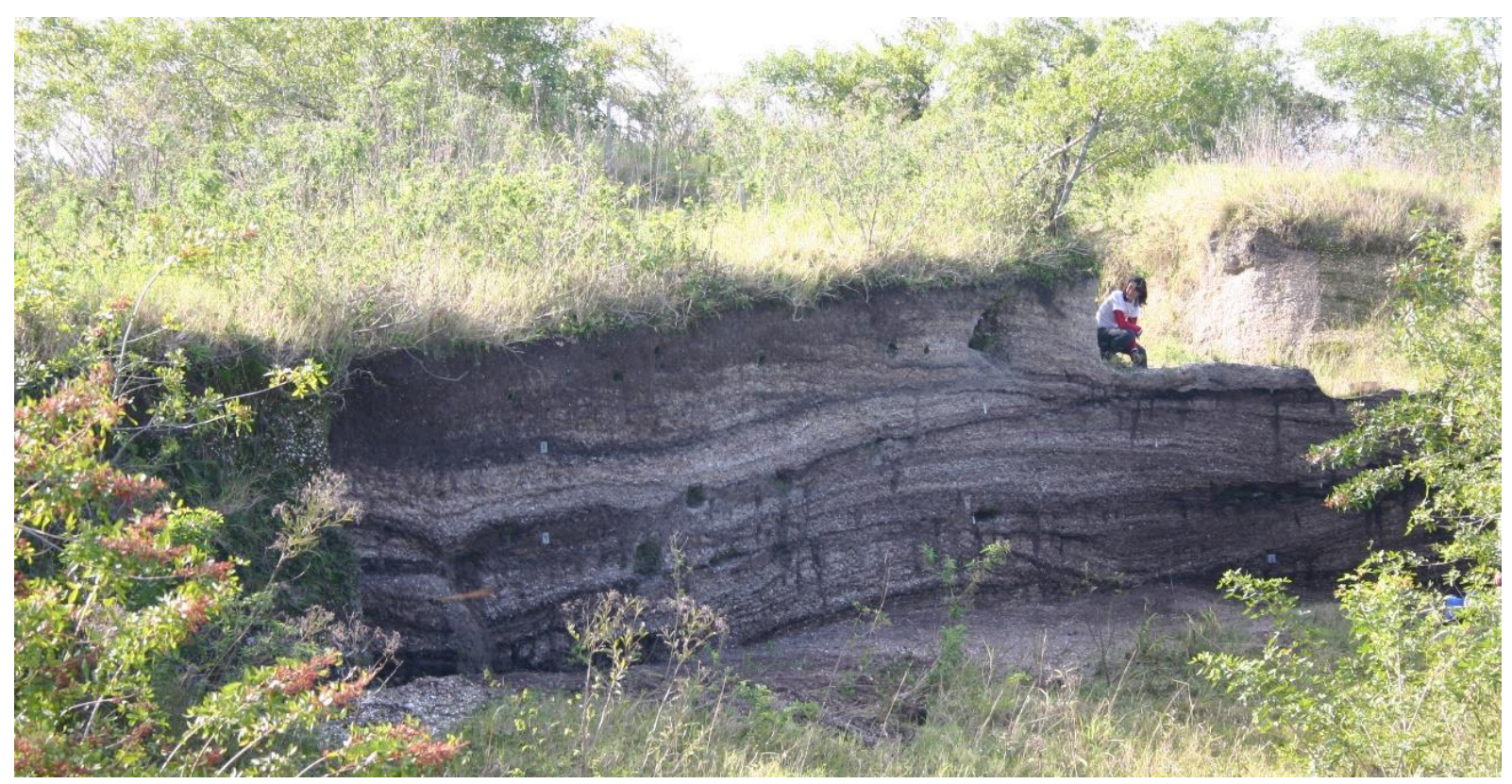

Figura 16. Sambaqui Jaboticabeira 2, em uma das frentes voltadas para SE. Foto: P.C.F. Giannini. 


\section{Sambaqui Perrixil (CNSA: SC01665)}

Um dos sambaquis menos conhecidos, o Perrixil, ou Ponta do Perrixil, (22J 715601/ 6861021; Figura 17), localiza-se no município de Laguna, no setor nordeste de Giannini et al. (2010) (Figura 5), sobre um tômbolo lagunar a leste de morrote testemunho do embasamento granitoide pré-cambriano. Encontra-se intensamente explorado, além de invadido por ocupações irregulares, restando antiga frente de lavra em montículo de menos de $5 \mathrm{~m}$ de altura por $10 \mathrm{~m}$ de extensão e $5 \mathrm{~m}$ de largura. É constituído predominantemente por ostras, que formam espessa sucessão com mais de $3 \mathrm{~m}$ de espessura; na porção superior, ocorrem lentes de $A$. brasiliana.

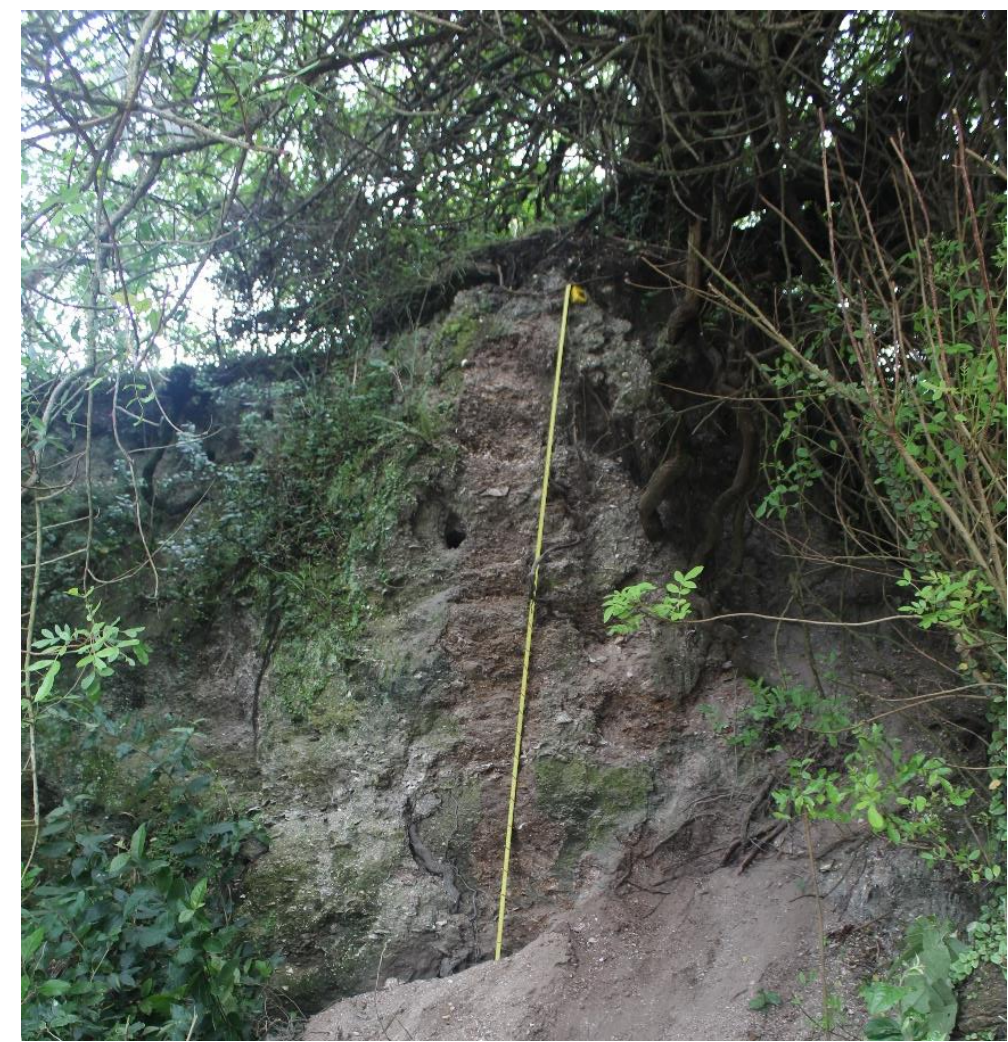

Figura 17. Corte no sambaqui Perrixil 


\section{Sambaqui Santa Marta 2 (CNSA: SC00718)}

O sambaqui Santa Marta 2, ou Cabo de Santa Marta 2 (22J 713230/6833590; Figura 18), encontra-se sobre média vertente, na porção sul do cabo de Santa Marta (Laguna), em meio a afloramentos graníticos cobertos por paleodunas que 0 embasam (Giannini, 1993; Assunção, 2010).

Com idades que vão desde cerca de 4400 anos cal AP até aproximadamente 3200 anos cal AP, encontra-se bastante destruído, com sua porção sul e central removida para a construção de um estacionamento (Assunção, 2010), mas ainda mantém sua base e uma ombreira de aproximadamente $5 \mathrm{~m}$ de largura na sua lateral norte. Possui cerca de $130 \mathrm{~m}$ de comprimento, $125 \mathrm{~m}$ de largura e pelo menos $2,5 \mathrm{~m}$ de altura, estes expostos na ombreira mencionada, onde se podem observar camadas de conchas de $A$. brasiliana, queimadas e concrecionadas, carvão e artefatos líticos (Assunção, 2010).

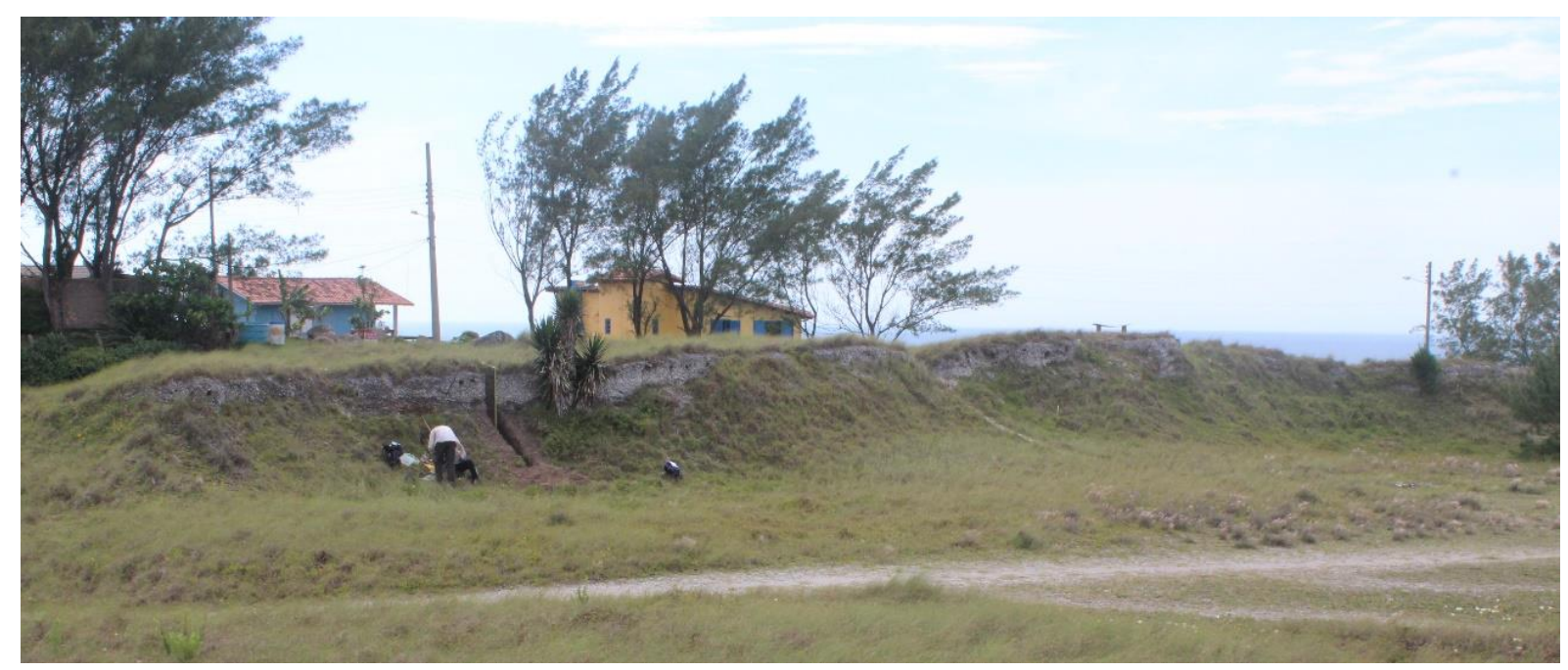

Figura 18. Sambaqui Santa Marta 2, visto a partir de sul. Foto: P.C.F. Giannini. 


\section{Depósitos paleolagunares}

Dentre os depósitos paleolagunares, o CPL, localizado próximo ao sambaqui Caipora (Figura 19) possui exposição de suas fácies conchíferas, em uma ampla extensão, devido à remobilização antrópica do terreno. Ocorrem fácies com conchas inteiras, articuladas e em posição de vida (Figuras 19 A, B) e, imediatamente sobre essas, fácies retrabalhadas, compostas por conchas fragmentadas e inteiras, preferencialmente desarticuladas (Figuras 19 C, D).
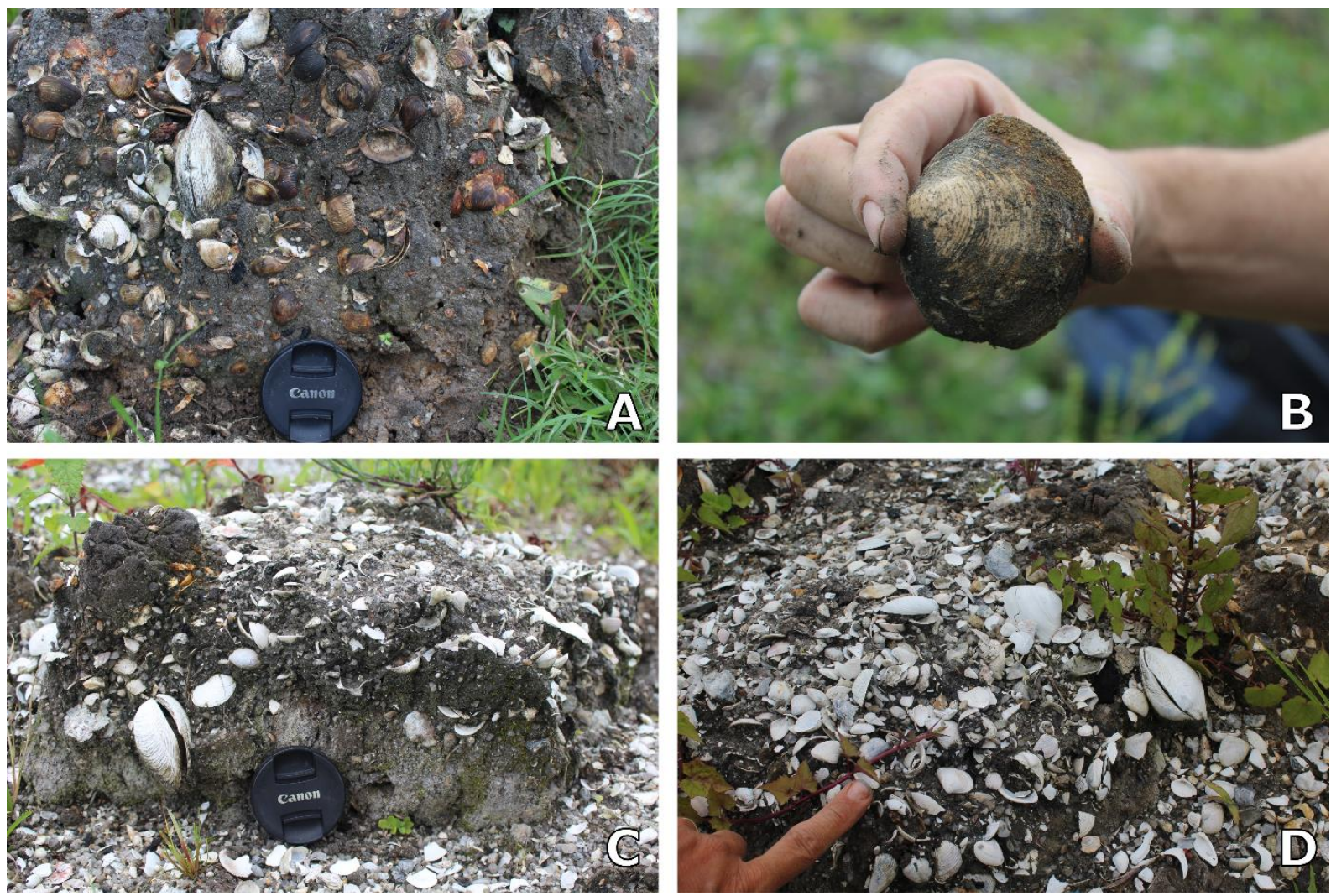

Figura 19. Depósito paleolagunar CPL, próximo ao sambaqui Caipora. A) Fácies contendo conchas inteiras e em posição de vida; B) O bivalve Phacoides pectinatus com as valvas articuladas e na posição em que se encontrava no sedimento (posição de vida); C) Contato entre a fácies com conchas preferencialmente inteiras com a fácies mais cascalhosa com conchas fragmentadas; D) Detalhe da fácies com conchas retrabalhadas. 
Os demais depósitos paleolagunares analisados (CNL, GSL, JBL e PXL) possuem fácies conchíferas localizadas em média, cerca de $60 \mathrm{~cm}$ abaixo de fácies arenosas a lamosas (Figura 20).

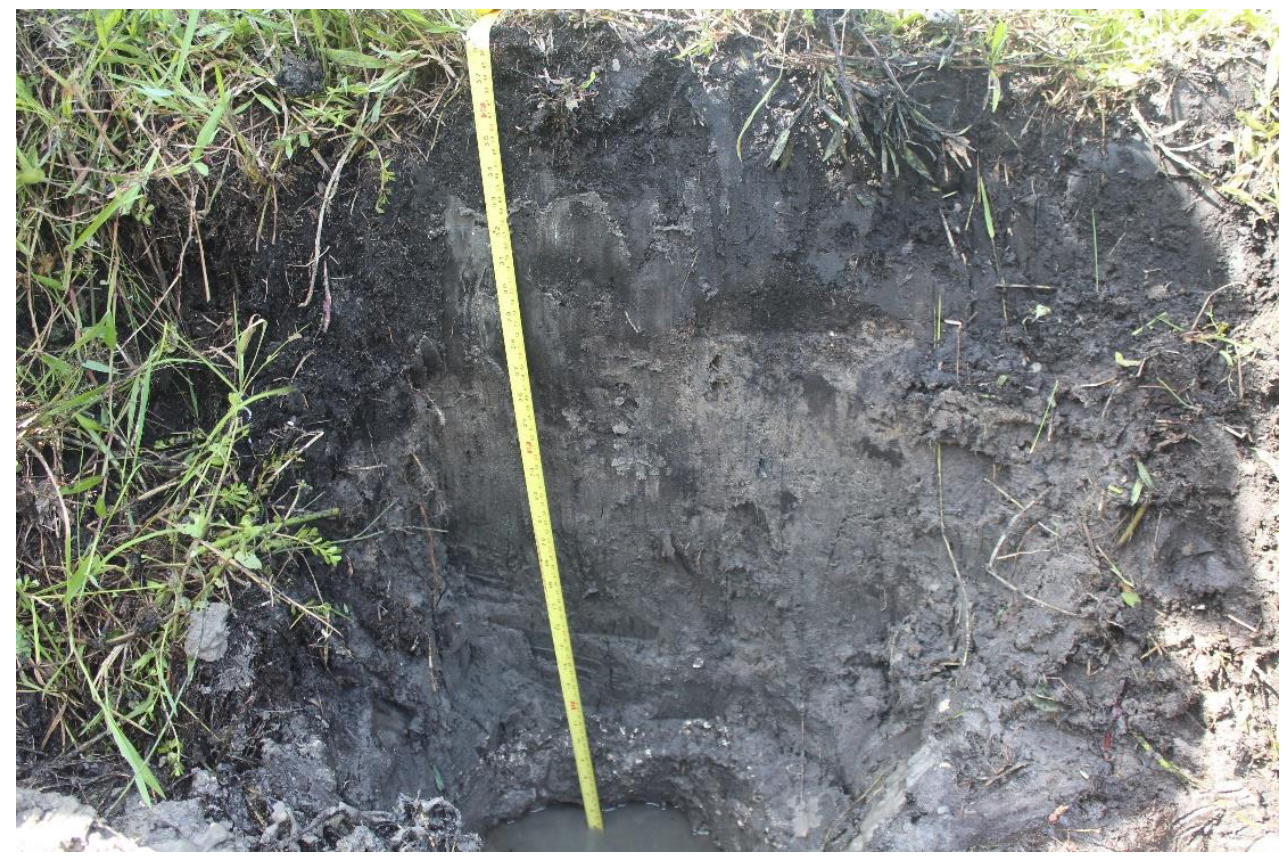

Figura 20. Depósito paleolagunar GSL com a fácies conchífera na base e, sobrepondo-se a ela, uma fácies arenosa, mais clara e, uma fácies areno-lamosa, mais escura.

\subsection{As conchas e o registro de vida}

Concha é o nome dado ao exoesqueleto calcário secretado por um semnúmero de invertebrados, que incluem, além dos moluscos abordados aqui, os braquiópodes e os crustáceos, como cracas e ostracodes. A formação da concha dos moluscos é biologicamente-controlada, não biologicamente-induzida, como acontece com a formação de esteiras microbianas, por exemplo; isto é, a mineralização é estritamente controlada pelos genes (Marin et al., 2012) e se dá em uma matriz orgânica, secretada por um de seus órgãos, o manto (Addadi et al., 2006). Nos bivalves, a concha é predominantemente composta por carbonato de cálcio $\left(\mathrm{CaCO}_{3}\right)$ - aragonita e/ ou calcita - e recoberta por um filme proteico constituído de conchiliolina, que confere resistência à dissolução, o perióstraco (Gordillo et al., 2014; Popov, 2014). O estreito campo de estabilidade química da aragonita na sedimentação e eodiagênese restringe-se a concentração $\mathrm{Mg} / \mathrm{Ca}$ em torno de 3:1, situação comum na água do mar, e sob salinidades acima de 17 (Folk \& Land, 1975). Desse modo, a aragonita secretada pelo molusco algumas vezes não se encontra em 
equilíbrio com o ambiente de vida do animal; nesses casos, sob condições naturais, ela se mostraria termodinamicamente instável e suscetível à dissolução e recristalização sob a forma de calcita (Marin et al., 2012; Gordillo et al., 2014).

Por outro lado, os valores de $\delta^{18} \mathrm{O}$ do carbonato da concha, incorporados durante o crescimento do molusco, se mostram em equilíbrio com a temperatura e com os valores de $\delta^{18} \mathrm{O}$ da água onde o animal se desenvolve (Gordillo et al., 2014). Os valores de $\delta^{18} \mathrm{O}$ de uma concha carbonática marinha dependem do $\delta^{18} \mathrm{O}$ da água onde ela se formou, do fracionamento isotópico eventualmente ocorrido no momento da cristalização e de processos fisiológicos, ou efeitos vitais (Ravelo e Hillaire-Marcel, 2007; Schoone, 2008; Poulain et al., 2015; Toniollo, 2014, 2017). Já os valores de $\delta^{13} \mathrm{C}$ das conchas marinhas é controlado pelos valores de $\delta^{13} \mathrm{C}$ do carbono inorgânico dissolvido na água e é um indicador de produtividade do meio (Craig, 1953; Gordillo et al., 2014). De forma análoga, alguns elementos podem ser incorporados à concha em quantidades relativas à encontrada nas águas circundantes (Poullain et al., 2015). É o caso, por exemplo, dos elementos alcalinos terrosos Mg, Sr e Ba (Chave (1954) Kinsman e Holland, 1969 Boyle et al., 1976, Toniolo, 2014, 2017).

Chave (1954) reconheceu pela primeira vez que o teor de $\mathrm{Mg}$ em carbonato biogênico é maior nas regiões de menor latitude e sugeriu que a substituição de $\mathrm{Ca}$ por $\mathrm{Mg}$ nos carbonatos em geral seria facilitada pelo efeito do aumento de temperatura.

A relação entre o teor de $\mathrm{Mg}$ na calcita e a temperatura ambiente é bem estabelecida. Sabe-se que na estrutura da calcita o $\mathrm{Mg}$ substitui facilmente $\circ \mathrm{Ca}$, pois tanto $\mathrm{O} \mathrm{MgCO}_{3}$ como a calcita formam cristais romboédricos. Como a reação de substituição é endotérmica, em cristais de calcita a razão $\mathrm{Mg} / \mathrm{Ca}$ aumenta junto com a temperatura (Kinsman e Holland, 1969).

Em cristais de aragonita, mineral formador das conchas de $A$. brasiliana, também se observa relação direta entre $o$ teor de $\mathrm{Mg}$ e a temperatura ambiente, embora o mecanismo de incorporação do Mg na estrutura cristalina deste mineral seja mais complexo. A capacidade da aragonita em admitir $\mathrm{Mg}$ em substituição aleatória ao Ca na sua estrutura cristalina é muito limitada, em comparação com a calcita. No entanto, o Mg pode ocorrer também em compostos orgânicos adsorvidos aos cristais de aragonita ou ainda em outras fases minerais (Takesue et al., 2008). 
Portanto, na maioria das espécies de carapaça ou esqueleto calcítico, pelas razões apresentadas, a relação do teor de $\mathrm{Mg}$ com a temperatura é amplamente aceita (Klein et al., 1996; Rosenthal et al., 1997). Já em organismos com carapaça aragonítica, ainda que os mecanismos sejam menos claros, há forte evidência para a relação diretamente proporcional entre o teor de $\mathrm{Mg}$ e a paleotemperatura das águas em diferentes espécies (e.g., de foraminíferos, cf. Rosenthal et al. (1997), e de corais, cf. Amiel et al. (1973), Wei et al. (1999), Raddatz et al. (2013)).

O Sr substitui facilmente o $\mathrm{Ca}$ em cristais de aragonita, visto que $\mathrm{SrCO}_{3} \mathrm{e}$ $\mathrm{CaCO}_{3}$-aragonita formam cristais isoestruturais (ambos ortorrômbicos). Como esta reação de substituição é exotérmica, em cristais de aragonita a razão $\mathrm{Sr} / \mathrm{Ca}$ diminui com o aumento da temperatura (Kinsman e Holland, 1969). Por isso, a razão $\mathrm{Sr} / \mathrm{Ca}$ em aragonita - seja orgânica ou inorgânica, lacustre, lagunar ou marinha - pode ser usada como paleotermômetro inverso, o que já é amplamente documentado em corais (Weber, 1973; Ullmann et al. 2013; Beck et al., 1992; Alibert e McCulloch, 1997).

$\mathrm{O} \mathrm{Ba}$ ocorre como elemento-traço incorporado randomicamente na estrutura de cristais de calcita e aragonita, sejam orgânicas ou inorgânicas, sendo que seu teor nos carbonatos reflete diretamente a concentração desse elemento na água do mar (Boyle et al., 1976). O teor de Ba na água do mar é um importante parâmetro na caracterização de diferentes massas de água. Por uma questão de afinidade geoquímica, ele encontra-se diretamente correlacionado com as concentrações de dois solutos, $\mathrm{SiO}_{2}$ e $\mathrm{HCO}^{3-}$, que podem ser oriundos tanto do intemperismo das rochas, no continente, quanto da dissolução de carapaças silicosas e carbonáticas no mar, a qual aumenta com a profundidade do oceano. Por esta correlação com a profundidade, $\mathrm{SiO}_{2}$ e $\mathrm{HCO}^{3-}$ integram os chamados nutrientes refratários das águas marinhas. Portanto, altos teores de $\mathrm{Ba}$, e consequentemente de sílica e íon bicarbonato, estão diretamente associados a alto aporte fluvial (Martin e Meybeck, 1979) e/ou a massas de água oceânicas ricas nestes nutrientes, especialmente $\mathrm{SiO}_{2}$ e $\mathrm{HCO}^{3-}$ (Chan et al., 1977; Lea e Boyle, 1989), como por exemplo, as águas profundas de um modo geral (Hall, 2002), inclusive ressurgentes.

Por essas razões, conchas de moluscos vêm sendo utilizadas há várias décadas como proxies paleoambientais, especialmente com relação à temperatura da água, eventos de ressurgência e mudanças na salinidade (Urey 1947; Epstein et al. 1951; Klein et al. 1996; Gordillo et al., 2014). 


\title{
2.2.1 Anomalocardia brasiliana
}

Na região de estudo, o molusco mais abundante, tanto nos concheiros naturais, como nos sambaquis, e presente até os dias atuais, é o bivalve Anomalocardia brasiliana (Gmelin, 1791), conforme pioneiramente registrado por Carlos Wiener, em comissão especial do Museu Nacional à região, ao final do século XIX:

\begin{abstract}
"A birbigôa (...) ainda hoje é uma especie muito espalhada, sendo sobretudo nas águas salobras que em maiores quantidades se encontra. (...) vive ahi n'um leito arenoso, á uma profundidade tão pequena que nas marés baixas se acha fóra d'agua. Nem fixada ao solo, nem a outros moluscos, e apenas coberta pela areia, não se comunica ás aguas do mar por esses tubos de que se servem certas espécies que vivem a alguns decímetros abaixo da superficie do leito" (Wiener, 1875, p.10).
\end{abstract}

Conhecida no litoral brasileiro por "berbigão", "vôngole", "maçunim", "chumbinho", "sernambi", "papa-fumo", "sarro-de-peito", "samanguaiá" e "pedrinha" (Boehs et al., 2008; Souza et al., 2011), a A. brasiliana é uma espécie de molusco bivalve lamelibrânquio da família Veneridae que vive em torno de dois a três anos (Monti et al., 1991; Rodrigues et al., 2013), podendo atingir até cerca de $30 \mathrm{~mm}$ de comprimento (Monti et al., 1991; Boehs et al., 2008; Colonese et al., 2017), com início da maturidade sexual quando a concha se encontra com cerca de $13 \mathrm{~mm}$ de comprimento (Barreira e Araújo, 2005).

Nas costas paulista e paranaense, o habitat preferencial de Anomalocardia brasiliana tem sido associado a fundos rasos de baías, lagunas e estuários, próximo ao nível médio de maré baixa (Narchi, 1974; Schaeffer-Novelli, 1980; Boehs et al., 2008; Angulo \& Souza, 2014), onde a ação frequente de ondas e correntes de maré favorece o fundo arenoso. Considerando a amplitude de maré astronômica e meteorológica média máxima na área em estudo, que é da ordem de $1 \mathrm{~m}$ (Giannini 1993), esta área corresponde a uma lâmina de água média de $50 \mathrm{~cm}$, contra 2 a 3m de profundidade máxima no sistema lagunar entre Jaguaruna e Laguna. A profundidade de enterramento é pequena, em torno de $5 \mathrm{~cm}$ (Narchi, 1974; SchaefferNovelli, 1980). Outros gêneros de moluscos, como Thais e Tagelus, associam-se no mesmo habitat. Em sedimentos paleolagunares holocênicos da região de Jaguaruna, conchas articuladas e em posição de vida de $A$. brasiliana foram encontradas em meio a sedimentos areno-lamosos, associados a espécimes de Tagelus sp., também em posição de vida, e de Thais sp., ambos de mesma idade (Angulo \& Souza, 2014). 
A manutenção de salinidades muito baixas $(<17)$ inviabiliza a presença da espécie (Leonel et al., 1983 apud Boehs et al., 2008). O estudo sobre o ciclo reprodutivo de $A$. brasiliana, conduzido por Barreira e Araújo (2005), no litoral do Estado do Ceará, mostrou que a diminuição da salinidade (16), como efeito do aumento da precipitação pluviométrica verificada em abril de 2003, induziu ajustes fisiológicos do animal frente a essas condições, influenciando em seu processo reprodutivo, com aumento do percentual de machos, em relação a fêmeas, nessa fase. Observações na baía de Paranaguá, na costa do Paraná (Boehs et al., 2008), demonstraram que a redução da densidade populacional de $A$. brasiliana durante 0 verão (dezembro-fevereiro) está provavelmente relacionada a aumento na taxa de precipitação pluviométrica nessa época do ano na região. Os autores ainda citam observação similar feita por Monti et al. (1991) em Guadalupe (Caribe), onde os períodos de chuvas intensas, acompanhados de elevação da mortalidade deste molusco, ocasionam não somente reduções bruscas na salinidade como também revolvimento de material do fundo, com consequente aumento da carga de sedimentos em suspensão; esta última condição é também inadequada para $A$. brasiliana, cujos sifões, curtos e fundidos, restringem sua presença a ambientes de águas calmas com baixas concentrações de silte e argila e pouco sedimento em suspensão (Narchi, 1974 e Bigarella et al., 1978 apud Boehs et al., 2008). Este efeito do aumento da carga em suspensão já fora descrito no clássico trabalho de Wiener (1875):

"Quando a maré sobe traz areia e quando desce, principalmente depois das chuvas, carrega lôdo. Este banco (...) põe paradeiro a estas massas de areia e de lôdo sobre as quaes as birbigôas morrem suffocadas; forma-se depois uma nova camada que é também suffocada e assim por diante até que a ilhota sobrepuje as baixas marés" (Wiener, 1875, p.16).

Colonese et al. (2017), no primeiro estudo conduzido sobre a calibração isotópica de conchas de $A$. brasiliana na região, verificaram que os valores de $\delta^{18} \mathrm{O} \mathrm{e}$ de $\delta^{13} \mathrm{C}$ respondem a uma série de condições, incluindo temperatura e salinidade. Nesse trabalho, os autores inferiram que os valores isotópicos de conchas do sambaqui Cabeçuda indicavam forte influência marinha, na região, em 3000 anos cal AP. 


\title{
2.3 As conchas e o registro de morte
}

\begin{abstract}
"A pesquisa tafonômica nos permite olhar para a profundidade das idades a partir de outro ponto de vista que aquele que é geralmente usado na Paleontologia. Portanto, estas pesquisas também são de grande importância para a Geologia, Paleogeografia, Faciologia e Sedimentologia." (Efremov, 1940, p.93).
\end{abstract}

O termo tafonomia (do grego: taphos, sepultamento; nomos, leis) surgiu, pela primeira vez na literatura científica, em 1940, como proposta de um novo ramo da paleontologia, que unia a geologia e a biologia em um método de estudo histórico geobiológico, preocupado com "as leis que governam a transição dos restos orgânicos da Biosfera para a Litosfera" (Efremov, 1940). As raízes desta ciência, no entanto, são mais profundas, e análises desta natureza já vinham sendo realizadas 40 anos antes por cientistas da escola alemã de aktuopaläontologie (ver Holz e Simões, 2002).

Assinaturas tafonômicas (Davies et al., 1988), presentes nas conchas dos depósitos em questão, tais como fragmentação, abrasão, incrustação, dissolução e corrasão, são indicativas dos processos ambientais vigentes à época do ciclo de vida destes organismos e durante as fases de deposição e de diagênese. Fragmentação, abrasão e incrustação, por exemplo, ocorrem nos restos esqueléticos que permanecem expostos na interface água/sedimento por prolongados períodos de tempo na chamada zona tafonomicamente ativa durante sua deposição ( $\mathrm{Holz}$ e Simões, 2002). Assim, as assinaturas tafonômicas, por guardarem em si informações acerca da dinâmica deposicional, podem ser utilizadas como parâmetro de identificação de fácies tafonômicas ou tafofácies (Speyer e Brett, 1986; Brett e Baird, 1986), ou seja, fácies definidas com base em traços tafonômicos diagnósticos (Speyer e Brett, 1986).

Uma definição mais moderna da tafonomia atribui a esta o "estudo dos processos de preservação e como eles afetam a informação no registro fossilífero" (Behrensmeyer e Kidwell, 1985), compreendendo duas amplas subdivisões: a bioestratinomia (que abrange os processos que vão da morte ao soterramento final) e a diagênese dos fósseis (que compreende as modificações físicas e químicas após o soterramento final).

Sob a óptica da tafonomia, os restos orgânicos, conforme apresentado inicialmente por Seilacher (1970), são considerados partículas sedimentares, ou seja, estão sujeitos aos mesmos processos de erosão, transporte e deposição que afetam 
os sedimentos clásticos, bem como aos efeitos de mistura temporal e espacial, desgaste físico-químico, seleção hidráulica e retrabalhamento. Além disso, sofrem a ação dos processos diagenéticos análogos aos de depósitos sedimentares em geral como compactação, cimentação, dissolução diferencial e recristalização (Holz e Simões, 2002).

Desta forma, na base epistemológica da análise tafonômica está a análise sedimentológica-estratigráfica, e diversos modelos atualmente empregados pela paleontologia requerem e utilizam conhecimento advindos da sedimentologia/ estratigrafia. Neste aspecto da relação entre tafonomia e condições de deposição, o modelo de fácies tafonômicas proposto por Brett e Baird (1986) e Speyer e Brett (1986) fornece uma base conceitual para a avaliação das características ambientais de hábitats particulares, por exemplo águas marinhas rasas ou profundas, e se baseia nas assinaturas tafonômicas quantificáveis, como articulação/desarticulação, fragmentação, abrasão, bioerosão, dentre outras (Speyer e Brett, 1988, 1991).

Fornari et al. (2012) valeram-se da análise tafonômica como um dos critérios para inferir os processos sedimentares responsáveis pela transição de uma baía para um sistema lagunar na porção sul (baía-laguna) da mesma região abordada aqui. A caracterização dos depósitos teve como base a orientação das conchas em relação à estratificação (caótico, oblíquo ou paralelo), o grau de empacotamento dos bioclastos (densamente empacotado ou fracamente empacotado) e a articulação dos espécimes (articulado ou desarticulado). Os atributos taxonômicos e tafonômicos foram essenciais para a separação das três FEGs regionais reconhecidas pelos autores. 


\section{METAS E OBJETIVOS}

Esta tese tem como meta científica a determinação da evolução climática e ambiental da região costeira centro-sul catarinense, durante o Holoceno médio a tardio, com base na análise dos depósitos conchíferos paleolagunares, sobretudo aqueles remobilizados no processo de construção de sambaquis.

Para atender a esta meta, foram estabelecidos os seguintes objetivos:

a) Caracterizar as fácies e associações de fácies dos depósitos naturais e antrópicos e as assinaturas taxonômicas e tafonômicas das conchas coletadas nos dois tipos de depósitos.

b) Obter uma cronologia fina, de resolução secular, acompanhada da composição isotópica $\left(\delta^{18} \mathrm{O}\right.$ e $\left.\delta^{13} \mathrm{O}\right)$ e química $(\mathrm{Ca}, \mathrm{Mg}, \mathrm{Ba}, \mathrm{Sr})$, em conchas de A. brasiliana.

c) Avaliar as variações nos atributos faciológicos, taxonômicos, tafonômicos e químico-isotópicos ao longo do intervalo de tempo coberto pelas datações.

d) Inferir, a partir dessas variações, as mudanças ambientais (e.g. salinidade, profundidade) ocorridas no sistema lagunar no Holoceno e discutir seu significado em termos de fatores controladores (nível relativo do mar, aporte continental, paleogeografia, paleoclima). 


\title{
4. MATERIAL E MÉTODOS
}

\subsection{Atividades de campo}

4.1.1 Seleção e exposição das áreas de coleta

\begin{abstract}
"Os massiços conchyliologicos da província de Santa Catharina apresentam, quando n'elles se executa um corte vertical, uma superfície geralmente esbranquiçada." (Wiener, 1875, p.11).
\end{abstract}

A seleção dos nove sambaquis estudados nesta tese baseou-se em dois critérios principais: a abundância de material conchífero, constituinte em comum dos sítios - e foco da pesquisa; e a extensão temporal que, em conjunto, eles abrangem. Para isso, consultaram-se previamente as datações de sambaquis da região disponíveis na literatura, com destaque para a compilação de idades apresentada por Giannini et al. (2010).

Uma vez selecionados os sambaquis, a escolha das áreas de coleta, dentro de cada um deles, priorizou seções previamente expostas, em sua maioria por ação do maquinário empregado para a mineração de calcário no início da segunda metade do século XX (Figura $21 \mathrm{~A}$ ). A estratigrafia evidenciada nestas seções permitiu a coleta, com o controle faciológico próprio para este tipo de estudo. Sempre que possível, e especialmente no caso de sambaquis muito grandes, optou-se por amostrar duas ou três seções, com o intuito de cobrir uma maior extensão temporal. A obtenção de duas seções, uma na parte mais basal da exposição, e outra, no topo, foi feita para os sambaquis Cabeçuda, Garopaba do Sul e Perrixil (respectivamente, seções CB1 e CB2, GS1 e GS2, PX1 e PX2); e a obtenção de três seções foi adotada no sambaqui Carniça 1 (seções CN1, CN2, CN3), onde CN2 e CN3 são verticalmente contínuas. Para os demais sambaquis, Carniça 3, Caipora, Jaboticabeira 1 e 2 e Santa Marta 2, foi amostrada apenas uma seção em cada (seções CC, CP, JC, JB e SM). Totalizamse, portanto, 14 seções amostradas.

A camada mais externa, subdecimétrica, de cada seção vertical foi removida previamente com o auxílio de pá e pincel, a fim de se evitar a coleta de materiais intemperizados ou escorregados de porções superiores, e também para possibilitar a visualização mais nítida das fácies (Figura 21 B). 

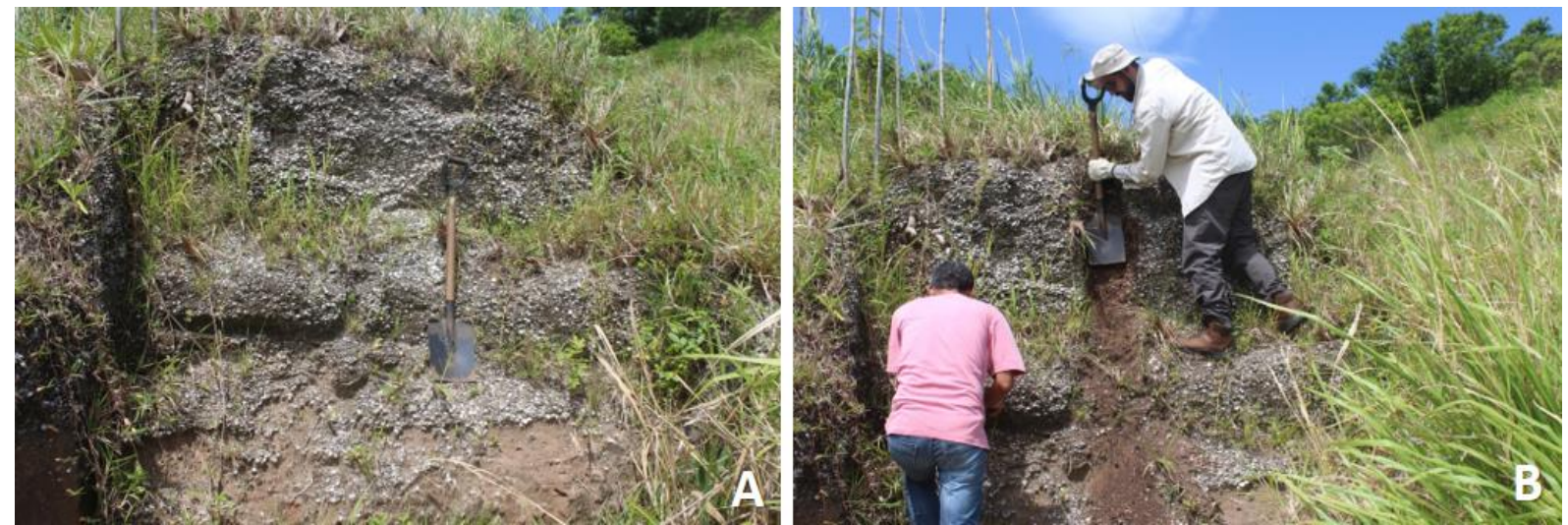

Figura 21. Seção 1 escolhida para coleta no sambaqui Cabeçuda (CB1):

A) como encontrada; B) durante a limpeza.

Já para os cinco depósitos paleolagunares estudados, cujas fácies conchíferas se encontravam cerca de $80 \mathrm{~cm}$ abaixo da superfície, próximas ao contato com o lençol freático (Figura 22), a amostragem se deu por meio de trincheiras abertas com o emprego de pá. Para o depósito CPL foram abertas duas trincheiras (CPL1 e CPL2, respectivamente), totalizando seis trincheiras amostradas.

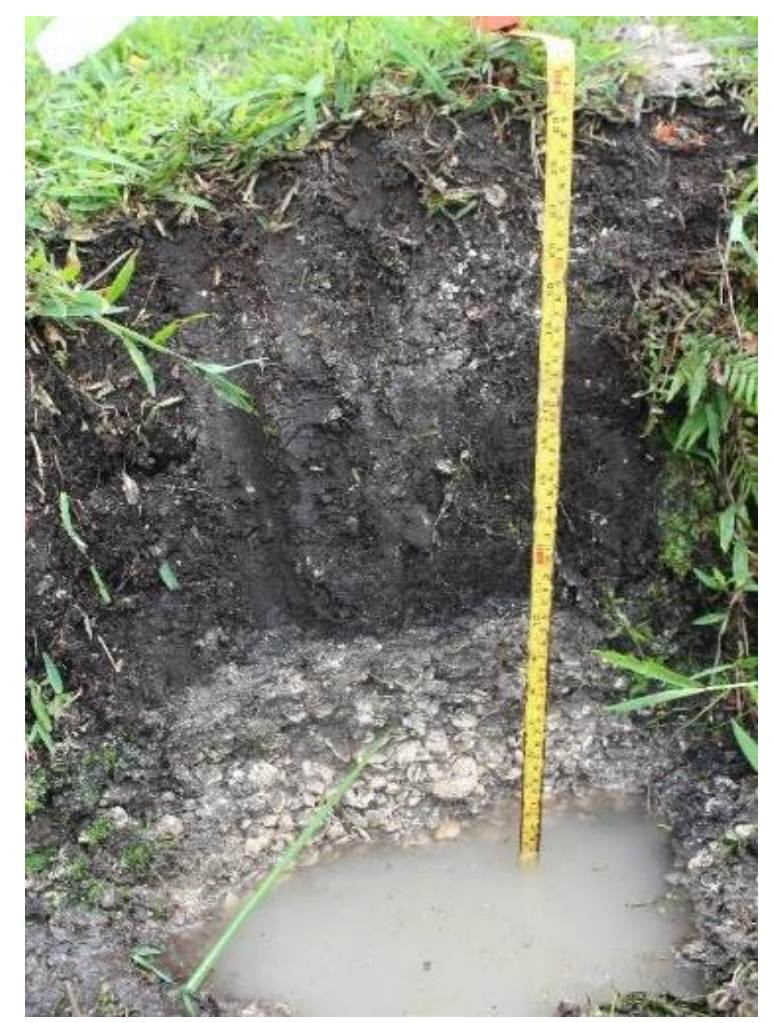

Figura 22. Depósito paleolagunar exposto por meio de trincheira (CNL), exibindo a proximidade do lençol freático com a fácies conchífera. 


\subsubsection{Aspectos operacionais da análise de fácies}

Os principais critérios adotados para a distinção de fácies, e atribuição de seus códigos, foram: 1) a granulação dominante ou modal (cascalho, areia ou lama), com indicação da granulação subordinada, na forma adjetivada, onde cabível (areia lamosa, cascalho arenoso etc.); 2) as feições características de cada fração granulométrica, tais como natureza composicional (e.g, intraclástica carbonática (conchas) e/ou fosfática (ossos) ou terrígena (por exemplo, quartzo e líticos)), constituição taxonômica, trama, articulação e estado de fragmentação das conchas, e indícios de presença de matéria orgânica associada ao arcabouço cascalhoso ou à matriz, esta, representada por material arenoso ou lamoso ou, ainda, por farinha de conchas ou de ossos; e 3) as estruturas sedimentares, como gradação e estratificação. Para a definição da granulação dominante ou modal, seguiu-se o diagrama triangular de classificação textural de Folk (1954), segundo o qual o cascalho é considerado dominante quando presente em proporção superior a $30 \% \mathrm{em}$ volume do total do depósito. Para fácies com menos de $30 \%$ de cascalho, considerouse dominante, de acordo com a mesma classificação, a granulação, dentre areia ou lama, que ocorria em maior proporção. O conceito de matriz foi usado no sentido descritivo, isto é, material clástico mais fino que o arcabouço cascalhoso.

Cada unidade de ocorrência ou de recorrência de determinada fácies, independentemente de sua forma, foi chamada de camada. Portanto, o conceito de camada adotado nesta tese é estratigraficamente confinado (sensu Walker, 1976 apud Walker, 2006), enquanto que o de fácies, por ser ela passível de recorrência, é estratigraficamente desconfinado. Em cada sambaqui, ou depósito paleolagunar, as camadas foram numeradas na ordem estratigráfica da base para o topo $(\mathrm{C} 1, \mathrm{C} 2, \mathrm{C} 3$ etc.), conforme exemplificado na Figura 23.

Foram dados códigos às fácies segundo o formato geral $X x Y y z$, onde $X$ e $Y$ representam a granulação principal e subordinada, respectivamente, $x$ e $y$ os atributos de trama e composição de cada granulação, e z a estrutura sedimentar (Tabela 1). 

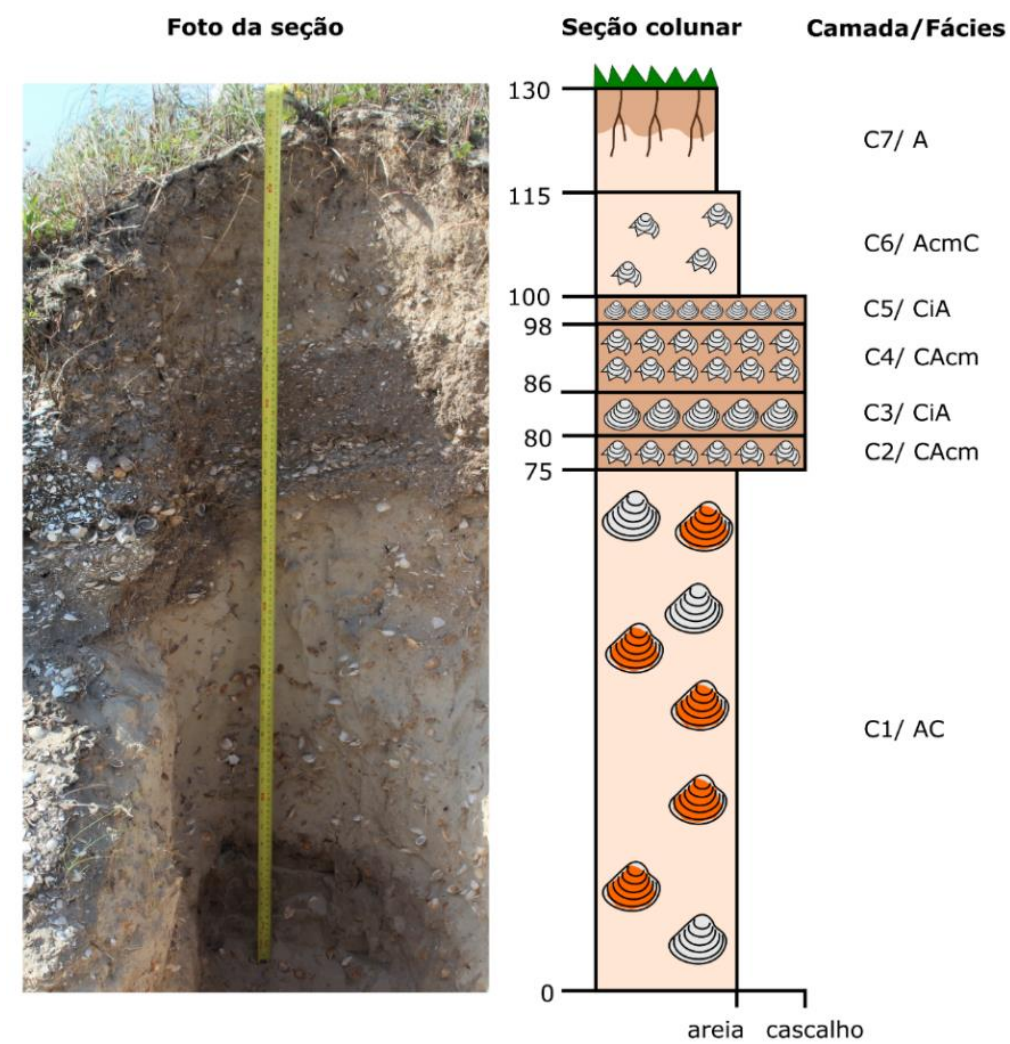

Figura 23. Exemplo de divisão em camadas ( $C 1$ a $C 7)$ e em fácies ( $A C, C A c m, C i A, A c m C, A)$. As camadas não se repetem por serem estratigraficamente confinadas, ao contrário do que pode acontecer com as fácies, como em CAcm e em CiA, onde há recorrências entre 86 e 100cm.

Tabela 1. Siglas adotadas para representar granulações e estruturas sedimentares, nos códigos de

\begin{tabular}{|c|c|c|}
\hline Natureza da informacão & Sigla & Descricão \\
\hline \multirow{4}{*}{$\begin{array}{c}\mathrm{X} \\
\text { Granulação }\end{array}$} & $\mathrm{C}$ & Cascalho conchífero ou de ossos \\
\hline & $T$ & Cascalho terrígeno \\
\hline & A & Areia \\
\hline & $\mathrm{L}$ & Lama \\
\hline \multirow{7}{*}{$\begin{array}{c}\mathrm{XY} \\
\text { Granulação composta }\end{array}$} & CA ou TA & Cascalho arenoso \\
\hline & CL ou TL & Cascalho lamoso \\
\hline & $A C$ & Areia cascalhosa \\
\hline & $\mathrm{AL}$ & Areia lamosa \\
\hline & LC & Lama cascalhosa \\
\hline & LA & Lama arenosa \\
\hline & $\mathrm{CAL}$ & Cascalho areno-lamoso \\
\hline \multirow{10}{*}{$\begin{array}{l}\text { x ou y } \\
\text { Atributo de composição } \\
\text { (inclusive taxonômica) } \\
\text { ou trama associada a } \\
\text { cada granulação }\end{array}$} & $\mathrm{I}$ & Líticos \\
\hline & 0 & Ossos \\
\hline & fo & Farinha de ossos \\
\hline & $\mathrm{cm}$ & Conchas moídas \\
\hline & $\mathrm{i}$ & Conchas inteiras \\
\hline & $\mathrm{q}$ & Conchas quebradas \\
\hline & pv & Conchas (bivalves) em posição de vida \\
\hline & ot & Ostras \\
\hline & $a b$ & Anomalocardia brasiliana \\
\hline & mo & Matéria orgânica \\
\hline \multirow{2}{*}{$\begin{array}{c}\mathbf{z} \\
\text { Estrutura sedimentar }\end{array}$} & $\mathrm{e}$ & Estratificação \\
\hline & $\mathrm{g}$ & Gradação normal \\
\hline
\end{tabular}




\subsubsection{Coleta}

Foram realizados três tipos de coleta em cada seção nos sambaquis, tendo em vista as diferentes análises que viriam a ser aplicadas posteriormente em laboratório. $\mathrm{Na}$ ordem em que foram obtidas em campo, estas três coletas visaram: 1) a datação e análises isotópicas e geoquímicas das conchas, aqui referidas pela abreviatura "D.I.G."; 2) à análise petrográfica das fácies; 3) às análises sedimentológicas dos depósitos e taxonômicas e tafonômicas dos bioclastos que os compõem. Previamente às coletas, a seção foi medida e fotografada e nela foram delimitadas cotas amostrais espaçadas de 5 ou $10 \mathrm{~cm}$, dependendo da extensão vertical analisada, eventualmente delimitadas com varetas de madeira para facilitar a visualização da malha de amostragem (Figura 24).

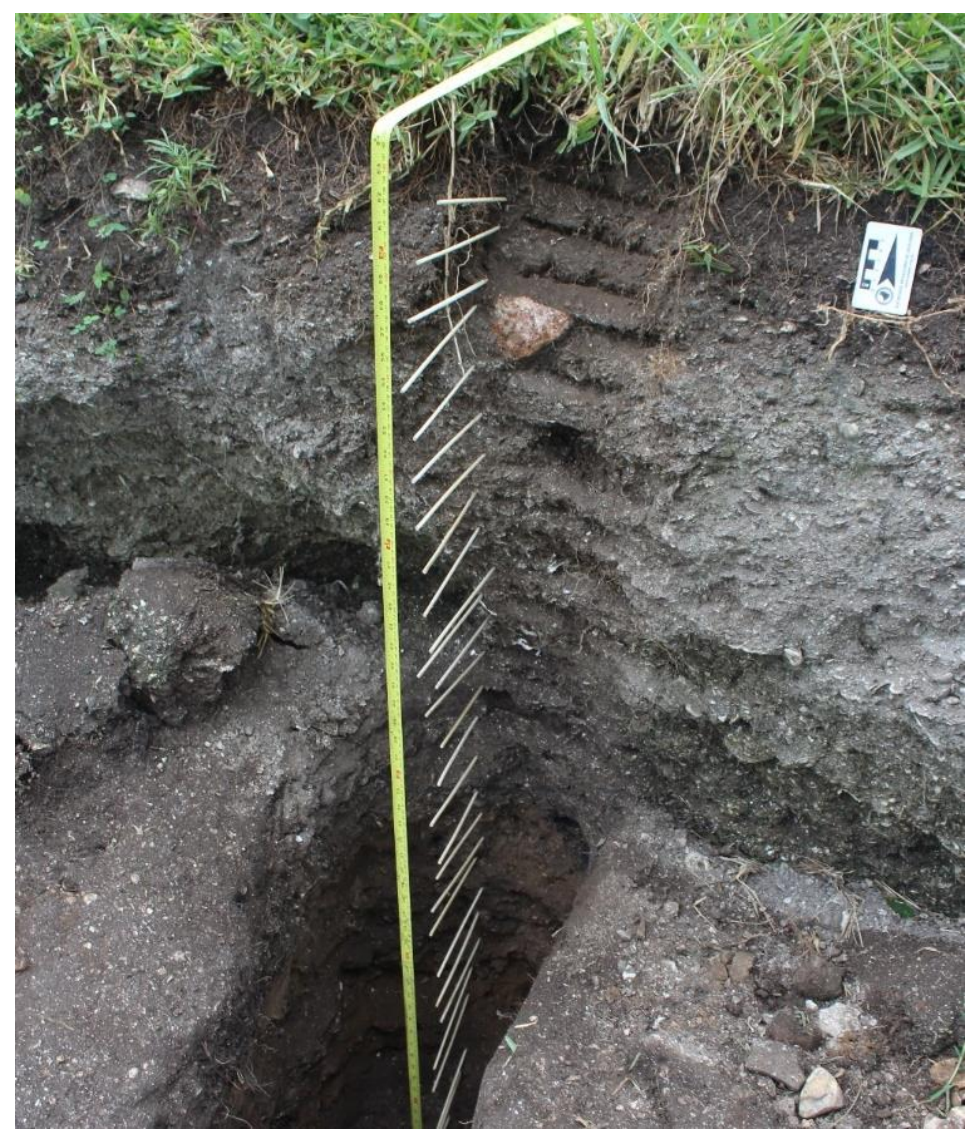

Figura 24.Seção do sambaqui Caipora exposta e dividida segundo cotas de amostragem (de 5 em 5 $\mathrm{cm}$ ) pré-determinadas, demarcadas por varetas de madeira.

Para D.I.G., foram coletadas em cada cota amostral da base para o topo, com uso de pinça metálica, pelo menos duas valvas de $A$. brasiliana, preferencialmente íntegras e articuladas, acondicionadas em seguida em sacos plásticos tipo ziplock (Figura 25). Carvão, sempre que observado, era coletado para a datação. 


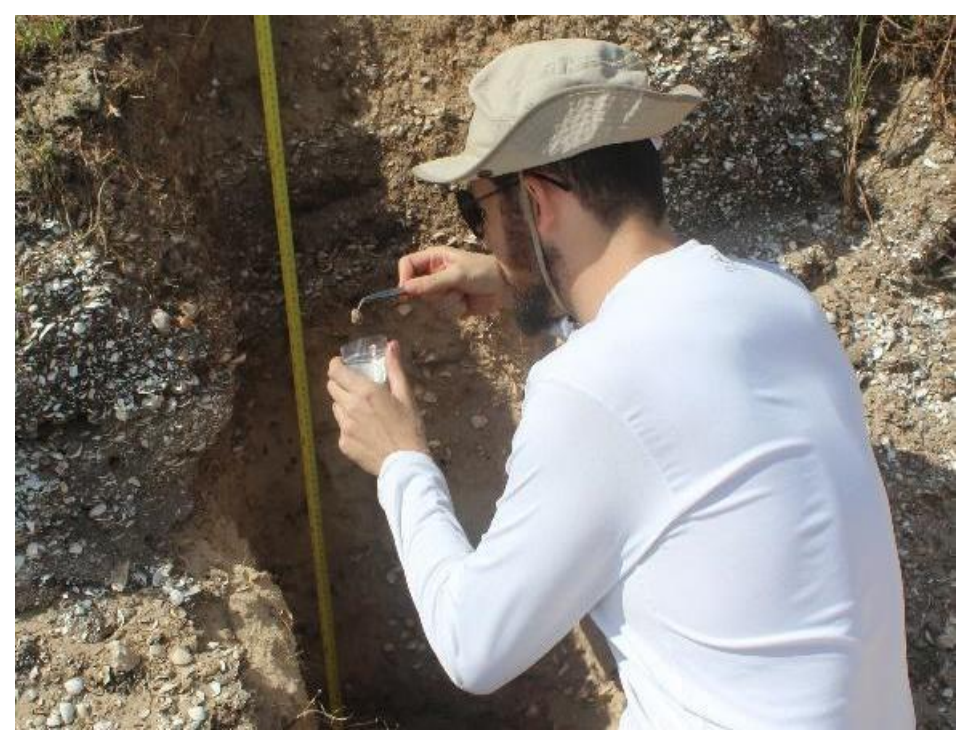

Figura 25. Coleta e acondicionamento das amostras para datação e análises isotópicas e geoquímicas (D.I.G.) na seção GS2.

Ao longo da coleta para D.I.G., foram observadas as feições macroscópicas sedimentológicas (e.g. granulação, cor, grau de empacotamento, estruturas) e tafonômicas (e.g. fragmentação, articulação), detalhadas no subitem anterior, que possibilitaram a identificação e descrição de 32 fácies em 67 camadas, nos sambaquis.

A etapa seguinte da coleta foi a retirada, na camada já amostrada para D.I.G., de torrões orientados, destinados a análise petrográfica. Este tipo de coleta foi possível para 25 camadas, correspondentes a 20 fácies distintas; nas demais, 0 material era muito incoeso e se desfazia ao contato, o que impossibilitou a amostragem do torrão orientado.

A sucessão de procedimentos adotada para a coleta destes torrões, baseada em Villagran (2012) e ilustrada pela Figura 26, foi a seguinte: 1) uma porção cúbica de aproximadamente $10 \mathrm{~cm}$ de lado foi esculpida na camada com uso de uma espátula e sobre o cubo aspergiu-se água a fim de manter o sedimento coeso; 2) as faces laterais do cubo foram envolvidas com atadura gessada, previamente molhada; 3) após a secagem do gesso, removeu-se a amostra com o auxílio de uma serra pequena ou da espátula; 4) o excedente da face interna (isto é, a voltada para a parede da seção) do torrão foi desbastado com o auxílio da serra pequena; 5) as áreas nãogessadas (interna e externa) foram cobertas com papel higiênico e o topo da amostra foi identificado à caneta; 6) a amostra foi envolvida com plástico filme e plástico bolha e, por fim, marcou-se o código de identificação da amostra na fita crepe envoltória. 

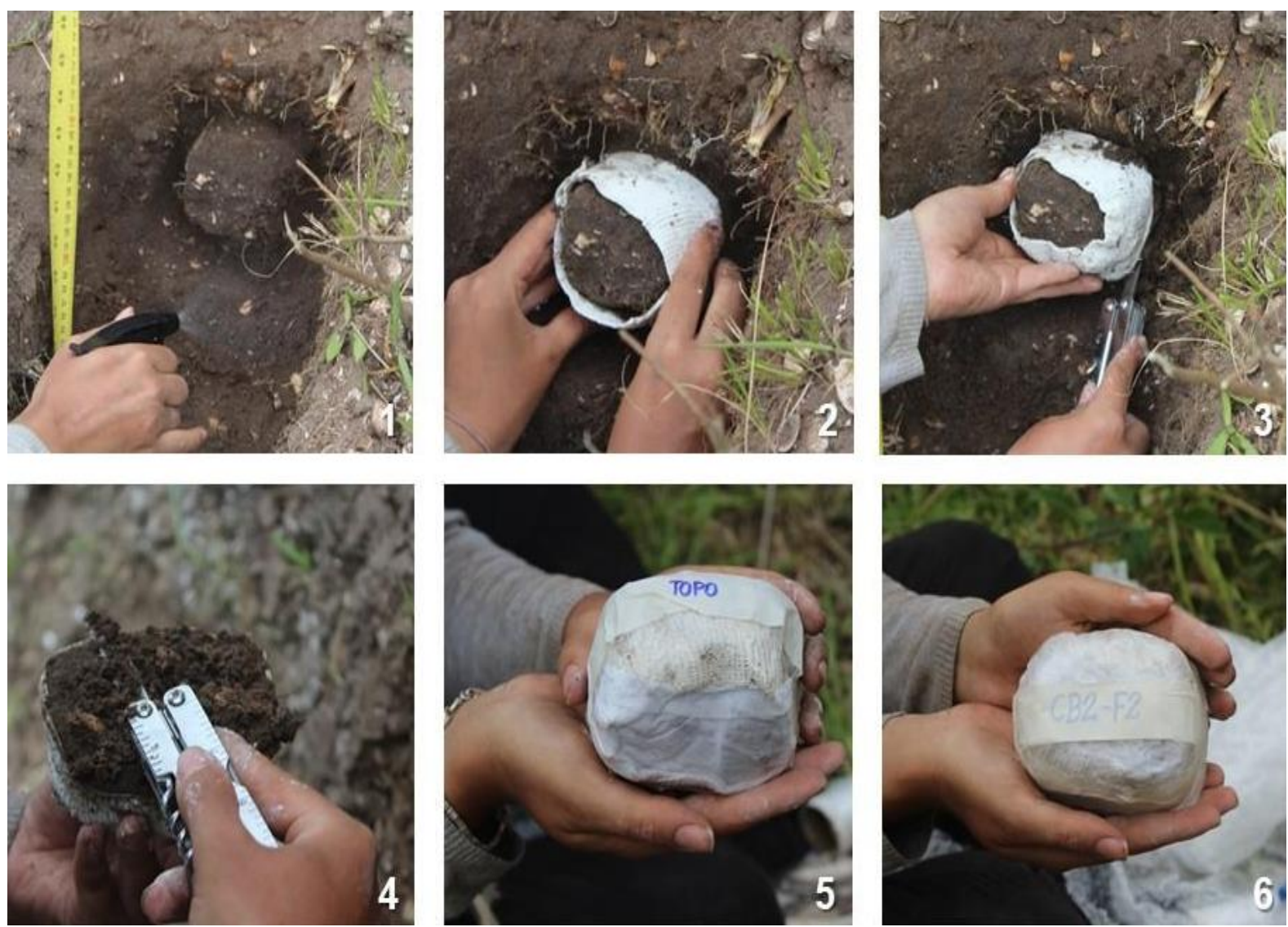

Figura 26.Procedimento de coleta de amostras para a análise petrográfica exemplificada pela camada CB2-C2: 1) esculpimento de um cubo na fácies e aspersão de água sobre ele; 2) envolvimento das laterais do cubo com atadura gessada molhada; 3) remoção da amostra; 4) desbastamento da face interna (voltada para a parede); 5) cobertura com papel higiênico das áreas não-gessadas e identificação do topo; 6) envolvimento da amostra com plástico filme e plástico bolha e identificação da amostra na fita crepe envoltória.

Por fim, dentro de cada camada, coletou-se cerca de $1 \mathrm{~kg}$ de sedimento bioclástico, destinado às análises sedimentológica e tafonômica. Este procedimento foi aplicado a 33 camadas que correspondem a 26 fácies diferentes. Detalhes da trama dos bioclastos, incluindo orientação e grau de empacotamento, foram depois recuperados em escala microscópica, por meio da análise petrográfica.

No caso das paleolagunas, o detalhamento em fácies teve que ser forçosamente mais simples, uma vez que a proximidade com o lençol freático dificultou a visualização e o controle estratigráfico e sedimentológico (Figura 18 B). Em vista dessa dificuldade, a coleta de amostras para análises D.I.G. segundo cotas determinadas, nos moldes da realizada nos sambaquis, não foi possível. Reconheceram-se 15 camadas paleolagunares, que, consideradas as recorrências, correspondem a 11 fácies diferentes. Foram coletadas, segundo os métodos descritos previamente para os sambaquis: seis amostras orientadas para a análise petrográfica, 
correspondentes a cinco fácies distintas; e sete amostras para as análises sedimentológica e tafonômica, provenientes de seis fácies distintas. Do material coletado para sedimentologia e tafonomia, extraíram-se também as conchas destinado às análises D.I.G.

\subsection{Atividades de laboratório}

Tendo como base a experiência e os trabalhos de cientistas que se debruçaram em questões sobre a sedimentologia e a arqueologia da região em estudo nesta tese (Amaral, 2008; Villagran, 2008, 2012, 2014; Menezes, 2009; Fornari, 2010; Nascimento Jr., 2011; Amaral et al., 2012; Villagran et al., 2009; Fornari et al., 2012; Toniolo, 2014, 2017) e respeitando as singularidades do objeto de estudo, foi elaborado um plano de trabalho com as técnicas analíticas necessárias para atender ao objetivo proposto. A seguir, estão detalhados os materiais e métodos usados na preparação das amostras para as diferentes finalidades.

\subsubsection{Datação e análises isotópicas e geoquímicas}

Um total de 123 valvas de $A$. brasiliana foi analisado para a determinação dos seus valores isotópicos de $\delta^{18} \mathrm{O}$ e $\delta^{13} \mathrm{C}$. Dessas, 99 também foram analisadas quimicamente, para a determinação das razões elementares de $\mathrm{Mg} / \mathrm{Ca}, \mathrm{Sr} / \mathrm{Ca}, \mathrm{Ba} / \mathrm{Ca}$; e 74 foram datadas via ${ }^{14} \mathrm{C}$ AMS, bem como 13 fragmentos de carvão. As valvas selecionadas para análise são provenientes de cotas determinadas ao longo das seções dos sambaquis e das amostras de cerca de $1 \mathrm{~kg}$ para tafonomia e sedimentologia, obtidas nas trincheiras em concheiros naturais.

As amostras selecionadas para datação foram obtidas a partir da secção de parte do lado posterior da valva com o auxílio da microrretífica Dremel. A porção restante destas amostras, bem como das 49 valvas íntegras, foi direcionada para as análises isotópicas $\left(\delta^{18} \mathrm{O}\right.$ e $\delta^{13} \mathrm{C}$ ) e geoquímicas (razões elementares de $\mathrm{Mg} / \mathrm{Ca}$, $\mathrm{Sr} / \mathrm{Ca}, \mathrm{Ba} / \mathrm{Ca}$ ) (Figura 27), detalhadas a seguir. 


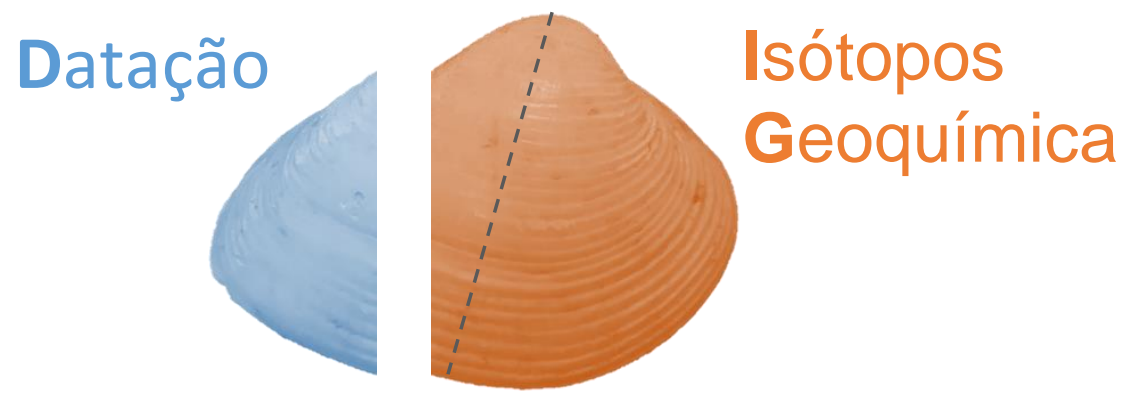

Figura 27. Valva de $A$. brasiliana seccionada para diferentes finalidades: a porção em azul foi direcionada para determinação da idade via ${ }^{14} \mathrm{C}$ AMS; do restante, em laranja, foram extraídas, as alíquotas para as análises isotópicas e geoquímicas a partir do eixo de maior crescimento da concha, destacado pela linha pontilhada.

Em decorrência das condições geoquímicas do ambiente de soterramento às quais estavam submetidas, as conchas dos depósitos analisados apresentavam, geralmente, a sua superfície alterada quimicamente (Figura 28); desse modo, sua análise implicaria sinais não correspondentes às condições isotópicas e geoquímicas das águas lagunares vigentes à época de vida destes moluscos, objetivo deste estudo.

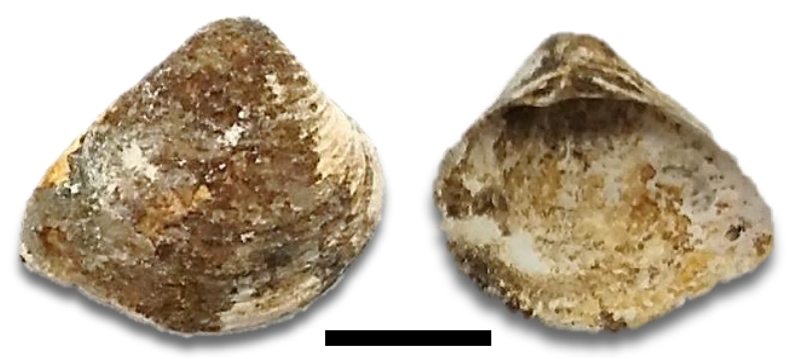

Figura 28. Valva de $A$. brasiliana com alteração química em sua superfície. Escala: $10 \mathrm{~mm}$.

Assim, a fim de realizar as análises isotópicas e geoquímicas no $\mathrm{CaCO}_{3}$ original da concha, optou-se por amostrar alíquotas do seu cerne, preservado da alteração externa. Os procedimentos de preparação das amostras para a coleta destas alíquotas basearam-se no método empregado por Carré et al. (2005) e estão descritos conforme segue: 1) a concha selecionada foi impregnada com resina epóxi em uma forma de silicone (preferencialmente com o eixo de maior crescimento da concha paralelo à parede da célula da forma em que ela foi inserida); 2) os cubos de resina contendo as amostras foram seccionadas com o uso de serra diamantada circular; 3 ) as amostras secionadas foram polidas em esmeril, usando-se carbeto de silício ( $\mathrm{SiC}$, carborundum) pulverizado como abrasivo (Figura 29). 

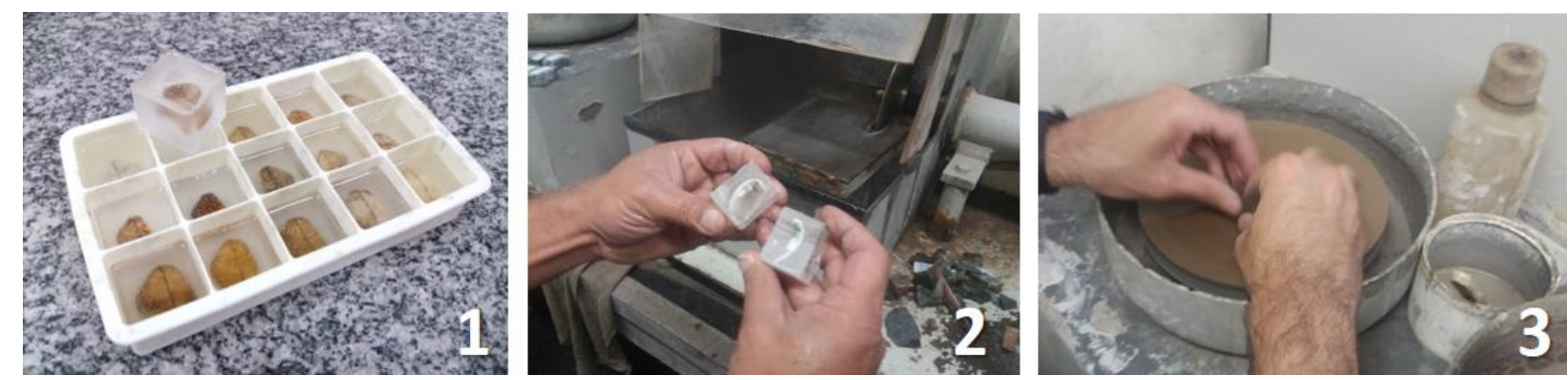

Figura 29. Principais passos da preparação para análise D.I.G.: 1) impregnação das valvas com resina epóxi, com eixo de maior crescimento previamente marcado a lápis; 2) seccionamento do cubo de resina no eixo de maior crescimento da concha e; 3) polimento no esmeril com carbeto de silício.

A amostragem das alíquotas de $\mathrm{CaCO}_{3}$ do interior da concha deu-se em uma das metades da valva seccionada, com o uso do micro-pulverizador Micromill. Em seguida, recolheu-se com espátula metálica o pó de $\mathrm{CaCO}_{3}$ obtido. Deste pó, uma fração de cerca de $100 \mu \mathrm{g}$ foi direcionada para as análises isotópicas enquanto que o restante (em média 4mg por amostra), para as análises geoquímicas (Figura 30).
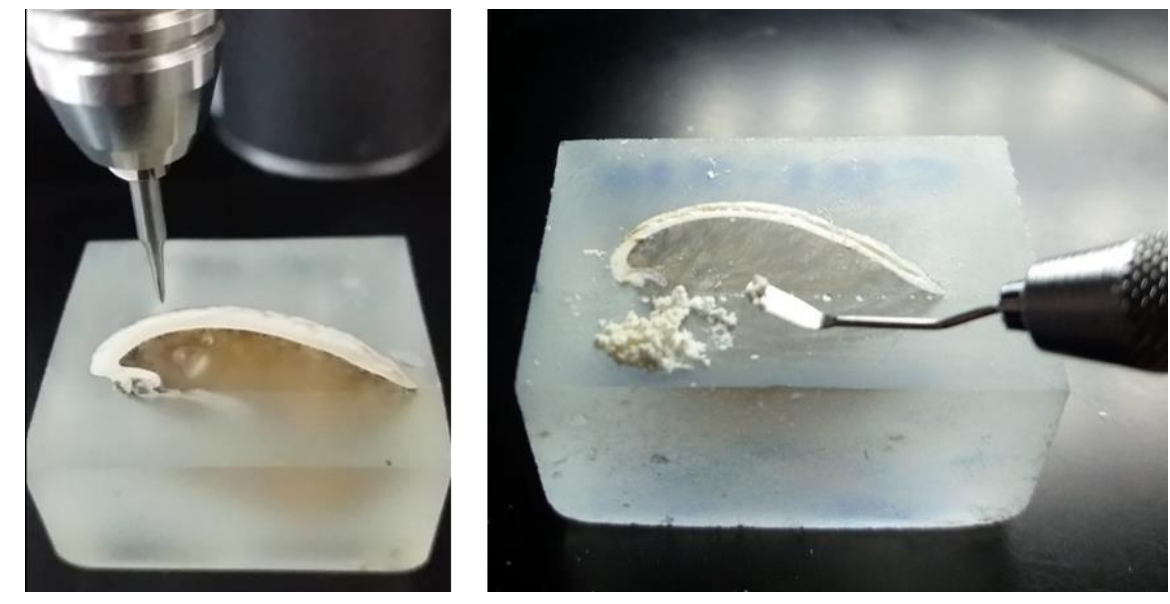

Figura 30. Amostragem, com uso de micro-pulverizador, de alíquotas de $\mathrm{CaCO}_{3}$ do cerne da concha embutida em resina epóxi.

A análise dos isótopos estáveis para a obtenção dos valores isotópicos de $\delta^{18} \mathrm{O}$ e $\delta^{13} \mathrm{C}$ foi realizada através da técnica de fluxo contínuo em GC-IRMS (cromatografia gasosa acoplada a um espectrômetro de massas de razão isotópica) (Figura 31). As razões isotópicas foram determinadas por meio do $\mathrm{CO}_{2}$ liberado a partir da reação do $\mathrm{CaCO}_{3}$ com ácido ortofosfórico $\left(\mathrm{H}_{3} \mathrm{PO}_{4}\right)$ a $72^{\circ} \mathrm{C}$. Os resultados são apresentados na notação convencional per mil (\%) em relação ao padrão Vienna Pee-Dee Belemnite (VPDB) para carbono e oxigênio. 


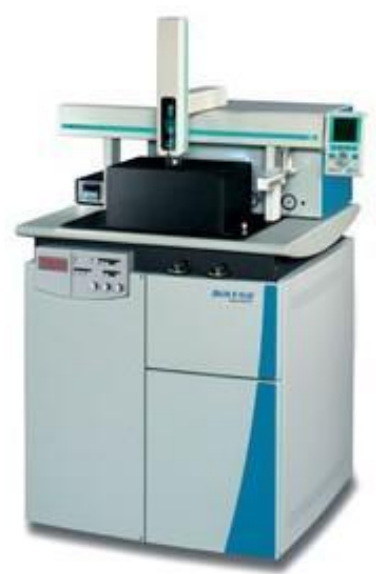

Figura 31. Equipamento utilizado na análise dos isótopos estáveis: GasBench acoplado a um espectrômetro de massas de razão isotópica.

Para a análise das razões elementares de $\mathrm{Mg} / \mathrm{Ca}, \mathrm{Sr} / \mathrm{Ca}, \mathrm{Ba} / \mathrm{Ca}$, fez-se necessária a diluição das alíquotas de $\mathrm{CaCO}_{3}$, como segue (Figura 32): 1) ० $\mathrm{CaCO}_{3}$ foi dissolvido com $\mathrm{HNO}_{3}$ puro e avolumado até $7 \mathrm{~mL}$ com água Milli-Q; 2) $100 \mu \mathrm{L} \mathrm{da}$ amostra foram pipetados e avolumados para $10 \mathrm{~mL}$ com $\mathrm{HNO}_{3} 5 \%$; 3) a amostra foi analisada por meio de espectrometria de emissão óptica com plasma (ICP-OES).
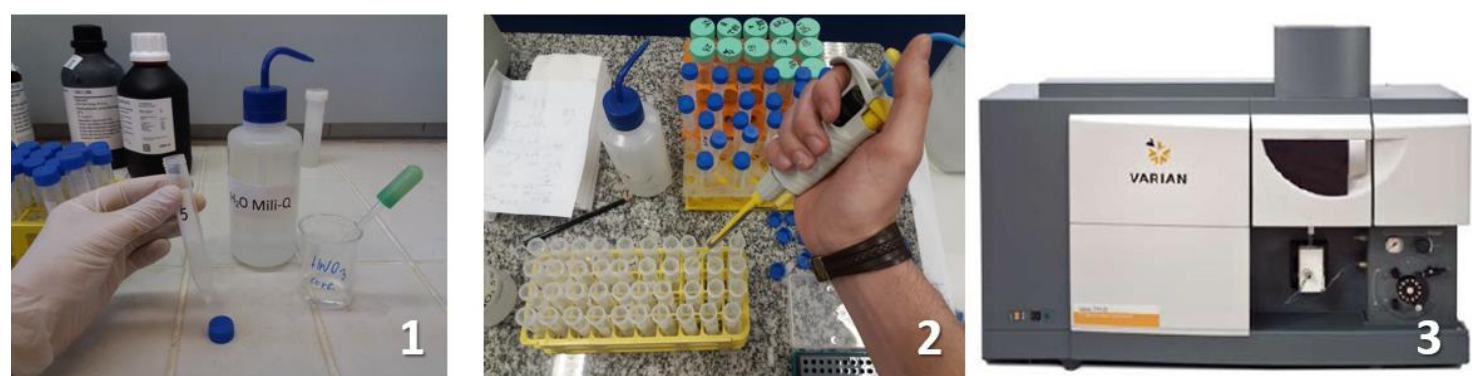

Figura 32. Procedimentos de preparação de amostras para as análises geoquímicas: 1) diluição do $\mathrm{CaCO}_{3} \mathrm{com} \mathrm{HNO}_{3}$ puro e avolumação até $7 \mathrm{~mL}$ com água Milli-Q; 2) pipetagem de $100 \mu \mathrm{L}$ da amostra e avolumação para $10 \mathrm{~mL}$ com HNO3 5\% e; 3) análise por meio de ICP-OES.

\subsubsection{Análise petrográfica}

A análise das amostras orientadas ao microscópio óptico de luz polarizada seguiu os procedimentos e terminologias da petrografia sedimentar. A preparação das amostras para essa análise incluiu basicamente sua impregnação em resina epóxi e a posterior secção e confecção de 26 lâminas petrográficas com espessura de $30 \mu \mathrm{m}$.

Previamente à impregnação, e após a remoção parcial do envoltório de gesso, as amostras foram levadas à estufa por pelo menos $48 \mathrm{~h}$. O método de impregnação, aplicado a seguir, e ilustrado pela Figura 33 , consistiu em: 1) preencher com resina corada o recipiente contendo a amostra previamente orientada e manter a amostra 
imersa por cerca de 1min; 2) submeter as amostras ao vácuo, por cerca de 2 min, em um dessecador de vidro; 3) retirar o vácuo, preencher o restante do recipiente com resina e reaplicar o vácuo pelo mesmo tempo; 4) secar as amostras em estufa por 24h; 5) uma vez secas as amostras, encaminhá-las para a confecção de lâminas petrográficas.
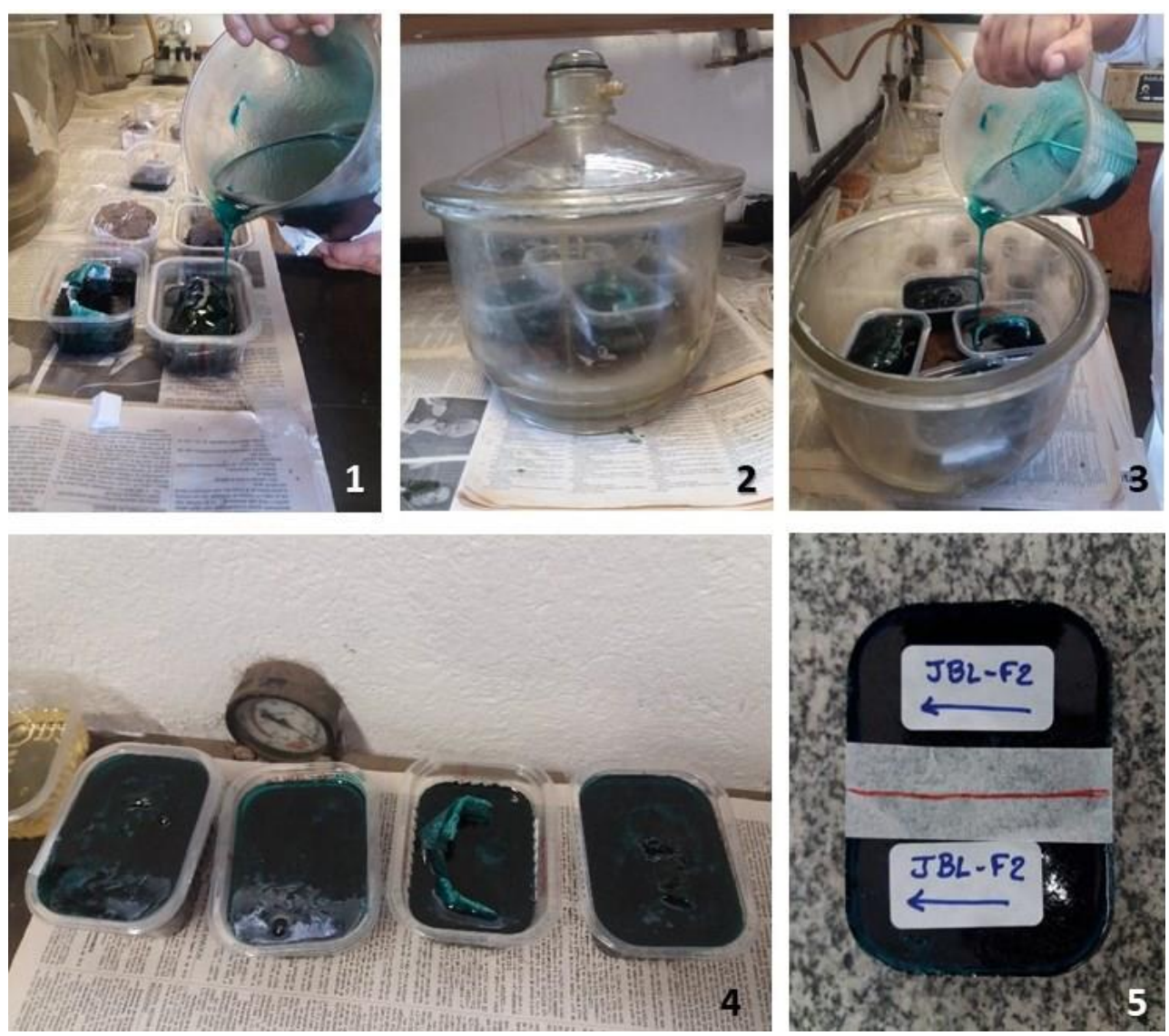

Figura 33. Principais passos da impregnação de amostras para a análise petrográfica: 1) preenchimento do recipiente contendo a amostra, com resina corada; 2 ) acondicionamento das amostras em um dessecador e aplicação de vácuo por 2min; 3) repetição das etapas 1 e 2; 4) secagem das amostras em estufa por mais $24 \mathrm{~h} ; 5$ ) orientação e identificação das amostras a serem seccionadas.

$\mathrm{Na}$ análise petrográfica, as lâminas foram descritas em microscópio óptico de luz polarizada Zeiss Axioplan. Os aspectos descritos englobaram: 1. reconhecimento e estimativa modal percentual de componentes petrográficos deposicionais (arcabouço e matriz ou micromassa) e diagenéticos (cimento e porosidade secundária); 2. identificação do componente de sustentação da rocha (se arcabouço, matriz ou cimento); 3. descrição do arcabouço quanto à mineralogia; 4. descrição do arcabouço quanto à textura, procurando-se avaliar: a granulação modal, o desvio-padrão e o grau de seleção granulométricos, de acordo com a tabela de estimativa visual de Pettijohn et al. (1973); e os parâmetros de forma (esfericidade e arredondamento) de grãos de quartzo, segundo a escala gráfica de Powers (1953); 5. descrição do arcabouço quanto à trama, com ênfase a segregação granular, 
gradação orientação, imbricação e empacotamento, este quantificado (em normal, aberto ou fechado) através do índice Ipk de Kahn (1956), que corresponde à razão percentual entre o número de contatos intergranulares e o número total de grãos, ao longo de uma linha paralela ao acamamento; 6 . descrição da mineralogia e textura do material autígeno, com indicação de possíveis gerações de cimentos; 7. descrição de tipos de contato intergranular e de feições de quebra ou deformação de grãos, e avaliação de seu significado enquanto indícios de compactação química e mecânica, respectivamente; 8. caracterização da porosidade conforme Choquette \& Pray (1970) e Schmidt et al. (1977). O processo de descrição foi acompanhado do registro em fotomicrografias através de analisador de imagens digitais LAS (Leica Analysis System).

Na descrição petrográfica, os termos micrita, microespato e espato foram utilizados na acepção de Folk (1968), para designar cristais de carbonato ou fosfato com dimensões menores que $5 \mu \mathrm{m}$, entre $5 \mu \mathrm{m}$ e $30 \mu \mathrm{m}$ e maiores que $30 \mu \mathrm{m}$, respectivamente. Também seguindo proposta desde autor, o prefixo do termo (e.g. calcimicrita, fosfamicrita) indica a composição química ou mineralógica dominante dos cristais (e.g. calcita, apatita, respectivamente). No caso dos fosfatos, reconheceu-se também a presença de massas coloidais ou colofanas, isto é, formadas por cristais não visíveis e/ou de arranjo cristalino precário (opticamente isótropos).

\subsubsection{Análise sedimentológica}

Para a análise granulométrica, o conjunto de técnicas usadas foi baseado no corrente do Laboratório de Sedimentologia "Armando Coimbra" do IGc-USP. Para cada camada amostrada, executou-se a seguinte sucessão de etapas, ilustrada nas Figuras 34 e 35: 1) uma alíquota de aproximadamente $200 \mathrm{~g}$ de amostra foi retirada; 2) fez-se sua dispersão em $200 \mathrm{~mL}$ de água deionizada acrescida de $1 \mathrm{~g}$ de pirofosfato de sódio tri-hidratado $\left(\mathrm{Na}_{2} \mathrm{P}_{2} \mathrm{O}_{7} .3 \mathrm{H}_{2} \mathrm{O}\right)$, com agitação de espátula plástica por aproximadamente $2 \mathrm{~min}$; 3) peneirou-se o material disperso, em malha de $2 \mathrm{~mm}$, com água deionizada; 4) ao passante, adicionou-se água deionizada até atingir, em uma proveta, pelo menos $1000 \mathrm{~mL}$, e a dispersão foi agitada com haste de base circular perfurada; 5) 58 s após o término da agitação (retirada da haste), pipetaram-se $20 \mathrm{~mL}$, a $20 \mathrm{~cm}$ de profundidade, conforme lei de Stokes, para coleta de alíquota representativa da concentração de silte e argila; 6) transferiu-se o pipetado para um becker de $50 \mathrm{~mL}$; 7) o restante do material da proveta foi elutriado; 8) o elutriado e o cascalho (etapa 3) foram filtrados, separadamente; 9) levou-se à estufa o elutriado, bem como o pipetado e o retido na malha $2 \mathrm{~mm}$ (cascalho), para secagem; 10) após 
a secagem, peneirou-se em classes de 1 phi o elutriado com o cascalho; 11) pesouse cada fração granulométrica, inclusive o silte mais argila (pipetado), e inseriram-se as massas no banco de dados da planilha Momento, a qual calcula a distribuição granulométrica em massa, em classes de phi, e as estatísticas relacionadas aos quatro momentos (média, desvio padrão, assimetria e curtose) segundo as fórmulas da técnica analítica dos momentos de Pearson.
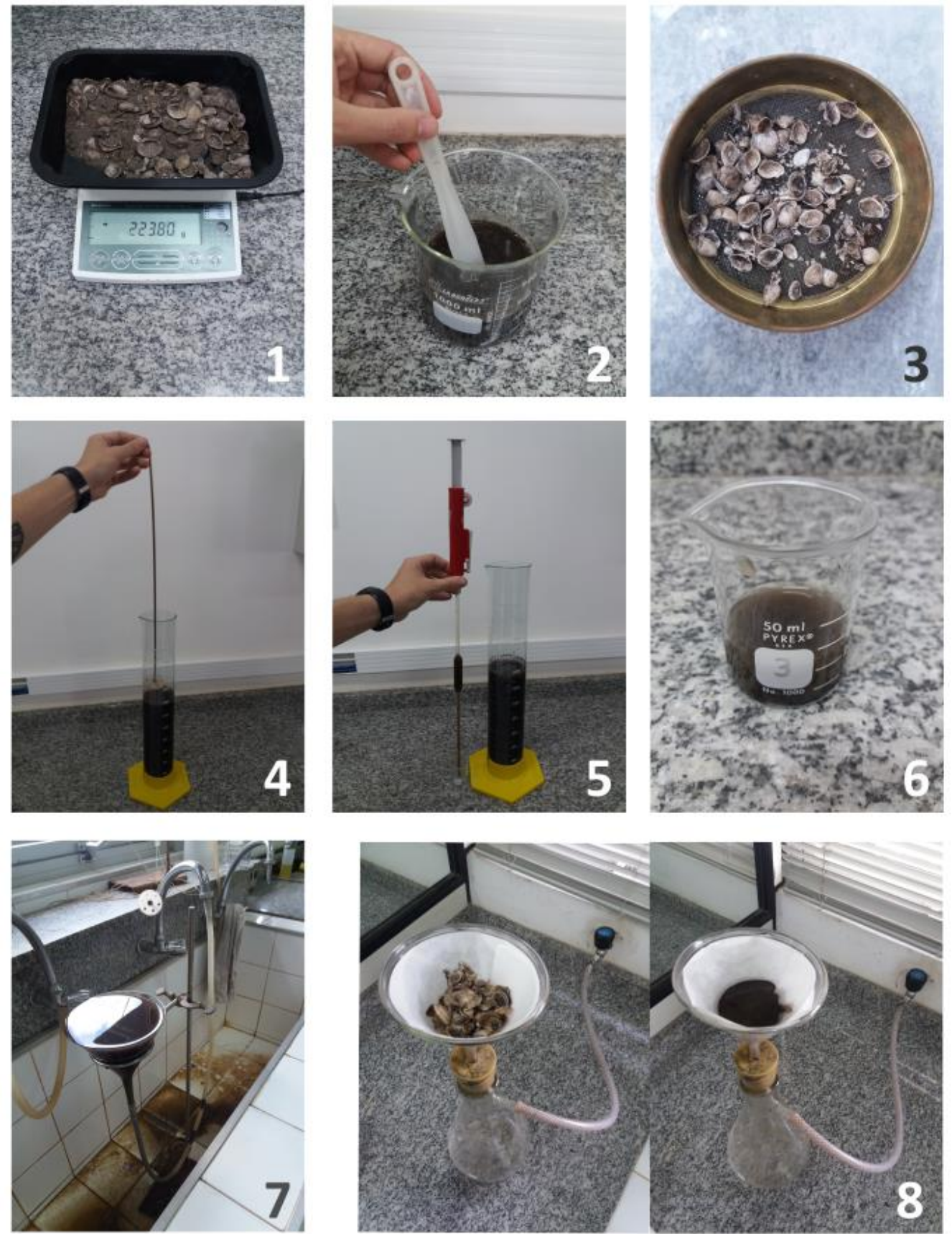

Figura 34. Preparação e coleta de dados granulométricos: 1) seleção de 200 g de amostra; 2) dispersão em $\sim 200 \mathrm{~mL}$ de água deionizada com $1 \mathrm{~g}$ de $\mathrm{Na}_{2} \mathrm{P}_{2} \mathrm{O}_{7} .3 \mathrm{H}_{2} 0$, por $\sim 2 \mathrm{~min}$; 3) peneiramento em malha de $2 \mathrm{~mm}$ com água deionizada; 4) agitação do passante com haste de base circular em proveta; 5) pipetagem de $20 \mathrm{ml}$ após $58 \mathrm{~s}$, a $20 \mathrm{~cm}$ de profundidade; 6 ) transferência do pipetado para um becker de $50 \mathrm{ml}$; 7) elutriação do restante do material; 8) filtragem do elutriado e o cascalho. 

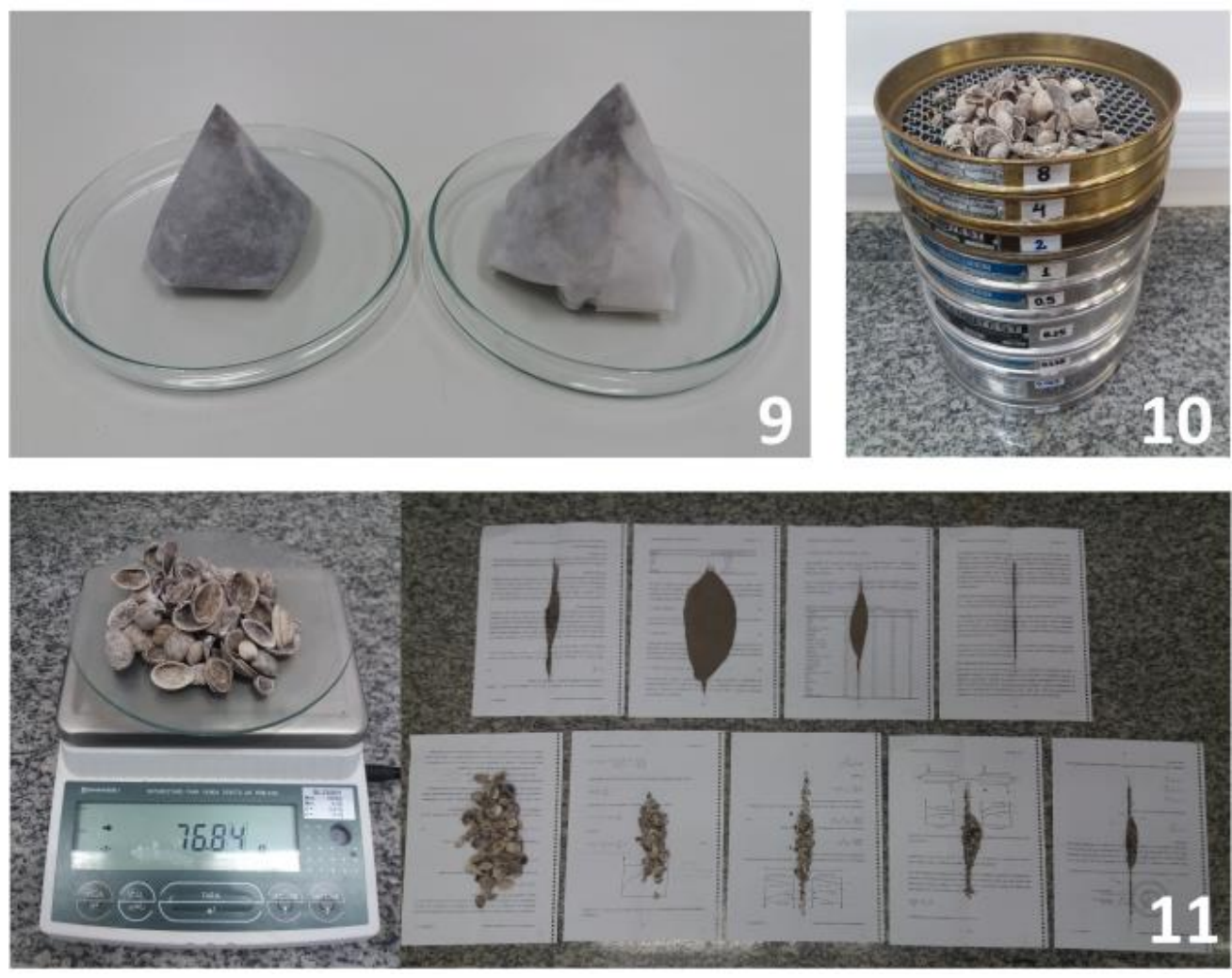

Figura 35. Preparação e coleta de dados granulométricos (continuação): 9) secagem, em estufa, do elutriado, do cascalho e do pipetado; 10) peneiramento do elutriado em classes de 1 phi; 11) pesagem de cada fração granulométrica.

Estes procedimentos foram aplicados nas 33 camadas amostradas de sambaquis e nas sete amostras das paleolagunas. O material obtido no fracionamento encontra-se arquivado no Laboratório de Sedimentologia "Armando Coimbra", no IGcUSP. O restante dessas amostras foi reservado para a análise tafonômica. 


\subsubsection{Análise tafonômica}

A análise das assinaturas tafonômicas nas conchas em estudo visa ao refinamento da caracterização faciológica e da interpretação de suas implicações paleoambientais. A aquisição e descrição dessas assinaturas teve como base Kidwell et al. (1986), Davies et al. (1988), Best e Kidwell (2000a, b), Simões e Ghilardi (2000) e Kidwell et al. (2001). O método empregado foi adaptado a partir de análises tafonômicas aplicadas em conchas de depósitos paleolagunares análogos aos estudados aqui (Erthal, 2012; Ritter et al., 2013; Pereira, 2016).

Para cada camada, aplicou-se a análise tafonômica que consistiu em: 1) peneirar o material coletado, do qual foi retirada a alíquota analisada na etapa anterior (sedimentológica), em malha de $8 \mathrm{~mm}$ a seco; 2) lavar cuidadosamente o retido com água corrente e secar naturalmente; 3) coletar, sob aumento de 10x, as assinaturas tafonômicas de pelo menos 120 espécimes, incluindo fragmentos.

As assinaturas tafonômicas coletadas para 4263 bioclastos, resumidas na Tabela 2 e ilustradas pela Figura 37, incluem: 1) o grau de fragmentação, dividido em ausente, baixo ( $80 \%$ da valva presente), moderado ( $50 \%$ da valva presente) e alto (<20\% da valva presente); e 2) a corrasão ou a alteração da superfície da concha, observada em suas porções externa e interna, e por sua vez dividida em: 2.1) grau de dissolução: ausente (perióstraco ou brilho original preservados ainda que parcialmente), baixo (até $20 \%$ da concha com aparência de giz - "chalky"), moderado (20-70\% da concha com aparência de giz), alto ( $>70 \%$ da concha com aparência de giz); 2.2) grau de "oxidação", ou alteração da cor, para aramelo, marrom, vermelho ou preto: ausente, baixo ( $<50 \%$ da concha oxidada) e alto ( $>50 \%$ da concha oxidada); 2.3) grau de precipitação: ausente, baixo ( $<50 \%$ da concha precipitada) e alto ( $>50 \%$ da concha precipitada). $O$ comprimento do eixo maior do bioclasto e lado da valva também foram computados. 
Tabela 2. Assinaturas tafonômicas observadas

\begin{tabular}{|c|c|c|c|}
\hline \multicolumn{2}{|c|}{ Assinatura tafonômica } & Grau & Figura \\
\hline \multirow{4}{*}{\multicolumn{2}{|c|}{ Fragmentação }} & $0=$ ausente $(100 \%$ da valva presente $)$ & Fig. 2. A \\
\hline & & 1 = baixo ( $80 \%$ da valva presente) & Fig. 2. B1 \\
\hline & & $2=$ moderado $(50 \%$ da valva presente) & Fig. 2. B2 \\
\hline & & $3=$ alto $(<20 \%$ da valva presente $)$ & Fig. 2. B3 \\
\hline \multirow{10}{*}{ Corrasão } & \multirow{4}{*}{ Dissolução } & $\begin{aligned} 0= & \text { ausente (periostraco ou brilho original } \\
& \text { preservados ainda que parcialmente) }\end{aligned}$ & \\
\hline & & $\begin{array}{c}1=\text { baixo (até } 20 \% \text { da concha com aparência de } \\
\text { giz - chalky) }\end{array}$ & Fig. 2. C1 \\
\hline & & $\begin{aligned} 2= & \text { moderado }(20-70 \% \text { da concha com } \\
& \text { aparência de giz) }\end{aligned}$ & Fig. 2. C2 \\
\hline & & $3=$ alto $(>70 \%$ da concha com aparência de giz) & Fig. 2. C3 \\
\hline & \multirow{3}{*}{ Oxidação } & $0=$ ausente (sem alteração) & \\
\hline & & $1=$ baixo $(<50 \%$ da concha oxidada $)$ & Fig. 2. D1 \\
\hline & & $2=$ alto $(>50 \%$ da concha oxidada) & Fig. 2. D2 \\
\hline & \multirow{3}{*}{ Precipitação } & $0=$ ausente (sem alteração) & \\
\hline & & $1=$ baixo (<50\% da concha precipitada) & Fig. 2. E1 \\
\hline & & $2=$ alto $(>50 \%$ da concha precipitada) & Fig. 2. E2 \\
\hline
\end{tabular}

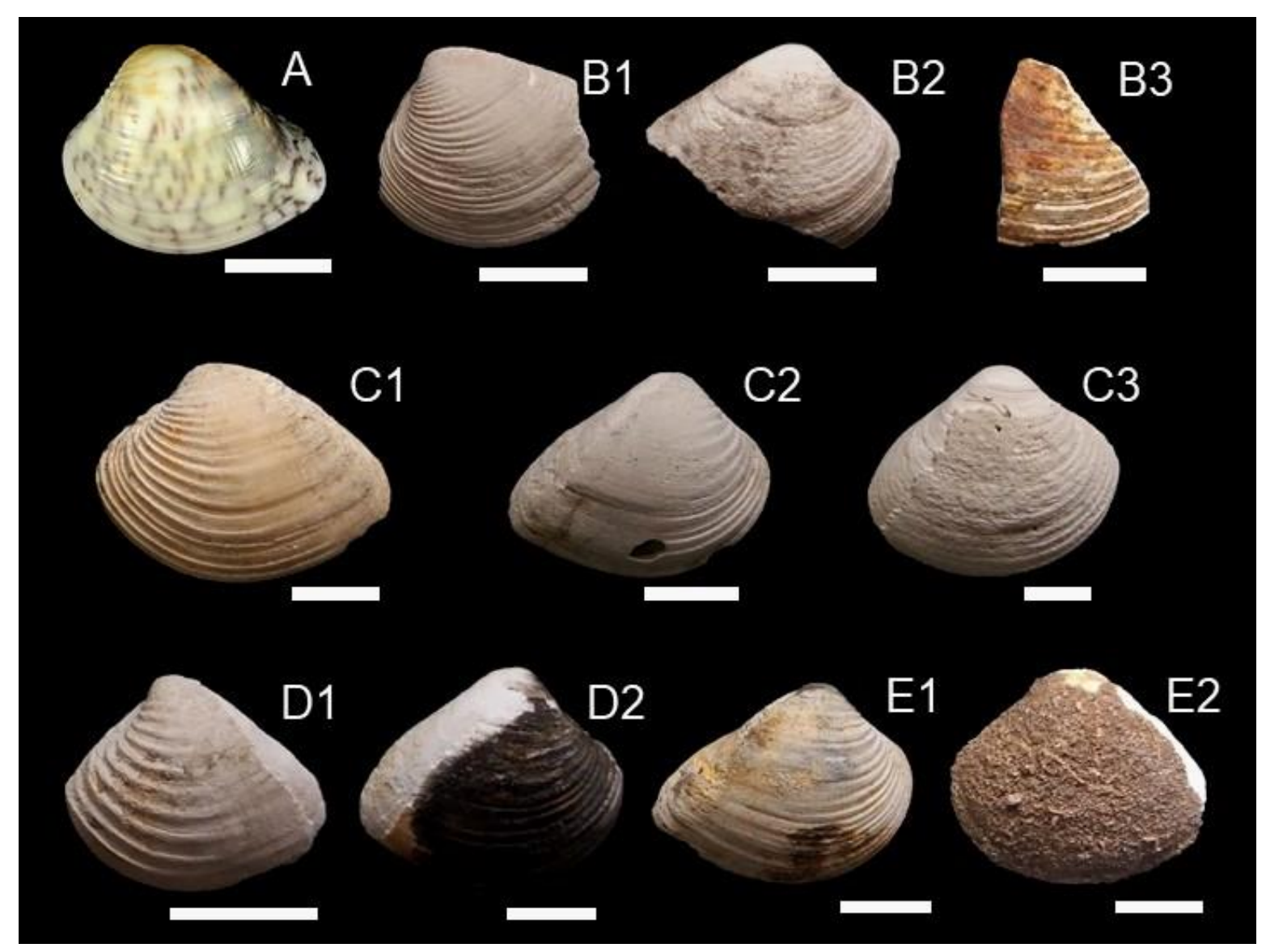

Figura 36. Assinaturas tafonômicas (cf. Tabela 1) observadas em conchas de A. brasiliana: A) perióstraco preservado e brilho original; B) graus de fragmentação; C-E) modificação da superfície: C) graus de dissolução; D) graus de oxidação; E) graus de precipitação. As alterações superficiais foram observadas externa e internamente. Barra de escala: $10 \mathrm{~mm}$. Todas as imagens obtidas a partir de espécimes dos sambaquis e concheiros naturais em estudo, exceto pelo espécime " $\mathrm{A}$ ", recente (foto: www.conchology.be). 


\subsubsection{MEV e EDS}

Foram executadas análises sob Microscopia Eletrônica de Varredura (MEV) para caracterização de feições de alterações superficial das conchas. Para tanto, foram obtidas imagens de alta resolução na topografia de superfície alterada, pela detecção de elétrons secundários (ETD). Adicionalmente, foram feitas microanálises químicas por espectrometria de energia dispersiva de raio-X (EDS) para obtenção de composição e abundância elementar pontualmente. As análises foram executadas em equipamento VPSEM FEI Quanta 250, operante no Centro de Pesquisas Geocronológicas (CPGeo, IGc-USP).

Para as análises foram selecionadas amostras nas seguintes camadas, e suas respectivas fácies: CB1-C2 (ACiq), CN3-C2 (CLAmo), GS2-C1 (AC), SM-C2 (ACiq), SM-C3 (CqA), CPL2-C1 (LaCpv), PXL-C1 (CiALmo) (Figura 38). Para evitar falhas de imageamento, previamente à execução das análises, a superfície não condutiva de todas as amostras foi recoberta por carbono através de evaporação à vácuo, no setor de preparo de amostras do Laboratório de Microssonda Eletrônica (ME, NAP Geoanalítica-USP). Para verificar a possível presença de carbono proveniente de matéria orgânica ou carbonosa associada às impregnações, foram executadas análises nas amostras CB1-F2, GS2-F1, SM-F2, SM-F3 e PXL-C1 previamente ao recobrimento de carbono.
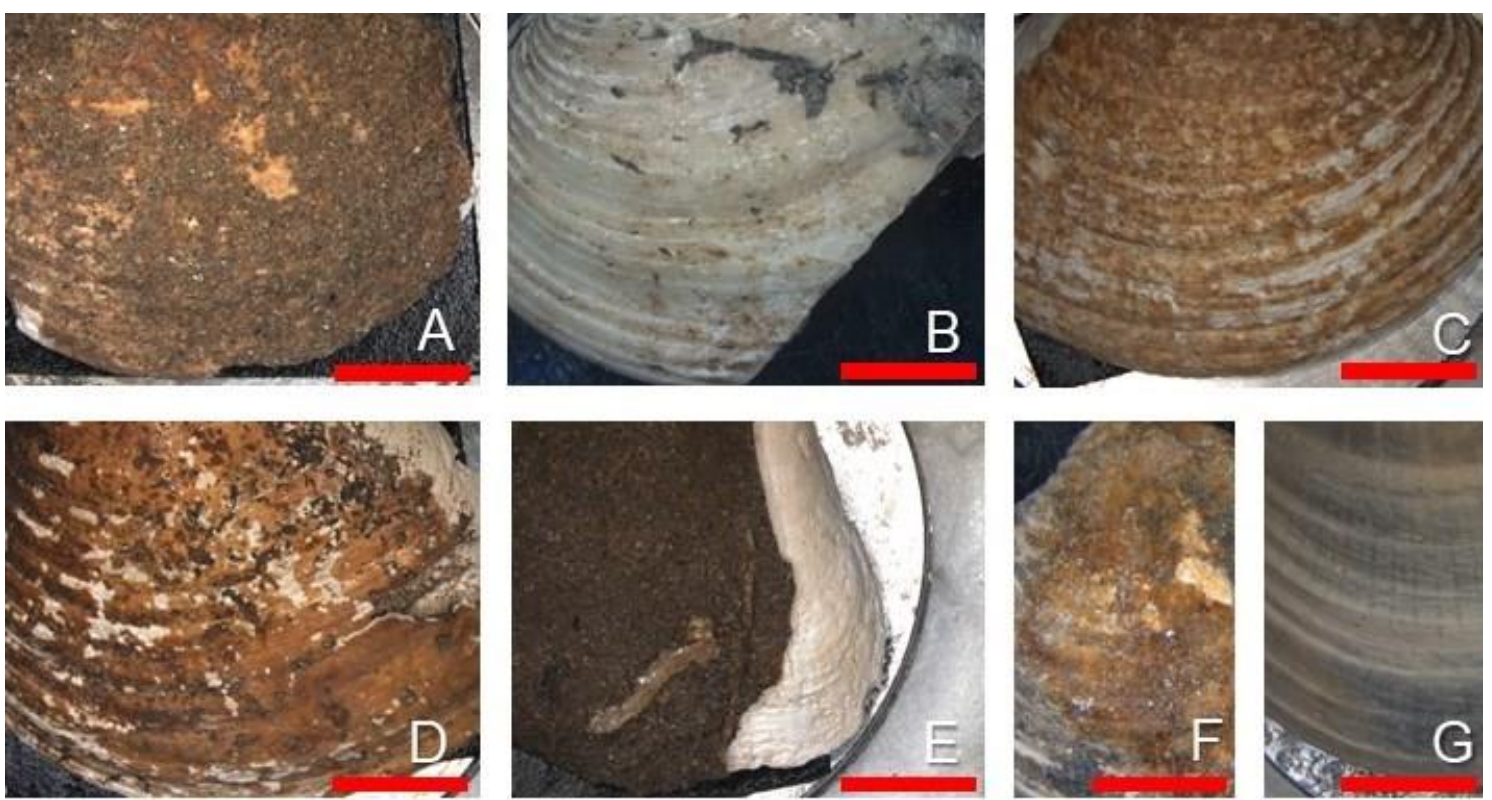

Figura 37. Fotos das amostras, feitas previamente à análise de MEV e EDS: A) CB1-C2; B) CN3-C2; C) GS2-C1; D) SM-C2; E) SM-C3; F) CPL2-C1 e; G) PXL-C1. Escala: 5 mm. 


\section{RESULTADOS}

\subsection{Idades}

Das 13 idades ${ }^{14} \mathrm{C}$ AMS obtidas a partir de carvões em sambaquis, oito mostraram sobreposição parcial com as idades de conchas de $A$. brasiliana coletadas no mesmo nível ou na mesma camada (Tabela 3), com discrepância máxima, encontrada na camada JB-C3, não superior a 147 anos, o que equivale a 8,0\% da idade mínima obtida no nível amostrado. As três camadas em que não houve sobreposição nos intervalos de idades do carvão e da concha de mesmo nível foram: CB2-C1, com discrepância (concha mais nova que carvão) de até 303 anos, o que equivale a 7,7\% da idade mínima obtida no nível amostrado; JB-C1, com discrepância (concha mais nova que carvão) de até 485 anos, correspondente a $26,1 \%$ da idade mínima encontrada na camada; e PX2-C3, em que a discrepância (carvão mais novo que concha) é de até 1748 anos, mesma ordem de grandeza da idade obtida no carvão.

Tabela 3. Amostras datadas de carvão pareadas com conchas de A. brasiliana.

\begin{tabular}{|c|c|c|c|c|}
\hline Sambaqui & Fácies & $\begin{array}{c}\text { Profundidade } \\
\text { (cm) }\end{array}$ & $\begin{array}{c}\text { Idade do carvão } \\
\text { (anos }{ }^{14} \mathbf{C} \text { cal AP) }\end{array}$ & $\begin{array}{c}\text { Idade da concha } \\
\text { (anos }{ }^{14} \mathbf{C} \text { cal AP) }\end{array}$ \\
\hline PX2-C3 & CotAfo/ CotAcm & 180 & $1542-1633$ & $3290-3448$ \\
\hline JB-C3 & Ccm & 120 & $1988-2105$ & $1841-2025$ \\
\hline JB-C1 & CiqLmo & 90 & $2343-2504$ & $1858-2044$ \\
\hline GS1-C5 & Ci & 100 & $2042-2208$ & $1952-2140$ \\
\hline GS2-C3 & CiA & 85 & $2751-2861$ & $2822-3032$ \\
\hline \multirow{2}{*}{ JC-C3 } & \multirow{2}{*}{ CiALmo } & 90 & $2304-2443$ & \\
\cline { 3 - 5 } & \multirow{2}{*}{ CB2-C3 } & 65 & & $2309-2496$ \\
\hline CB2-C1 & \multirow{2}{*}{ CA } & 150 & $3859-4087$ & $3810-4042$ \\
\cline { 2 - 5 } SM-C1 & \multirow{2}{*}{ CiA } & 10 & $4244-4446$ & $3927-4143$ \\
\cline { 3 - 5 } & & 10 & $4246-4447$ & $4301-4524$ \\
\hline
\end{tabular}

A disparidade de idades concha versus carvão em PX2 marca também uma das duas únicas inversões estratigráficas (sem sobreposição de intervalo) observadas em sambaquis; a outra ocorre na seção inferior (PX1) do mesmo depósito.

As idades ${ }^{14} \mathrm{C}$ das conchas de $A$. brasiliana coletadas em sambaquis e depósitos naturais e dos carvões provenientes dos sambaquis, ilustradas na Figura 39, estão compreendidas entre 6275-6452 anos cal AP e 1373-1542 anos cal AP. As idades da Figura 38 mostram também que, na maioria das seções estudadas em sambaquis, a deposição foi aparentemente contínua, sem evidenciar hiatos superiores 
a 200 anos, que é o intervalo aproximado de precisão das datações ${ }^{14} \mathrm{C}$ realizadas aqui. As exceções encontram-se justamente no sítio que teve inversões e discrepâncias entre concha e carvão, o Perrixil (PX1 e PX2), e também nos sambaquis Jaboticabeira 1, Cabeçuda e Santa Marta. Nestes quatro sítios, as idades obtidas podem em tese indicar dois intervalos diferentes de deposição no locus de amostragem do sambaqui, com hiato de mais de 1500 anos, no Perrixil, de aproximadamente 1300 anos, no Cabeçuda, e de cerca de 700 anos, nos demais.

Já nas seções de depósitos naturais, a única em que se datou mais de uma amostra, a JBL, apresentou, em quatro amostras, dois intervalos de idade muito diferentes, com discrepância de cerca de 4000 anos (Figura 38).

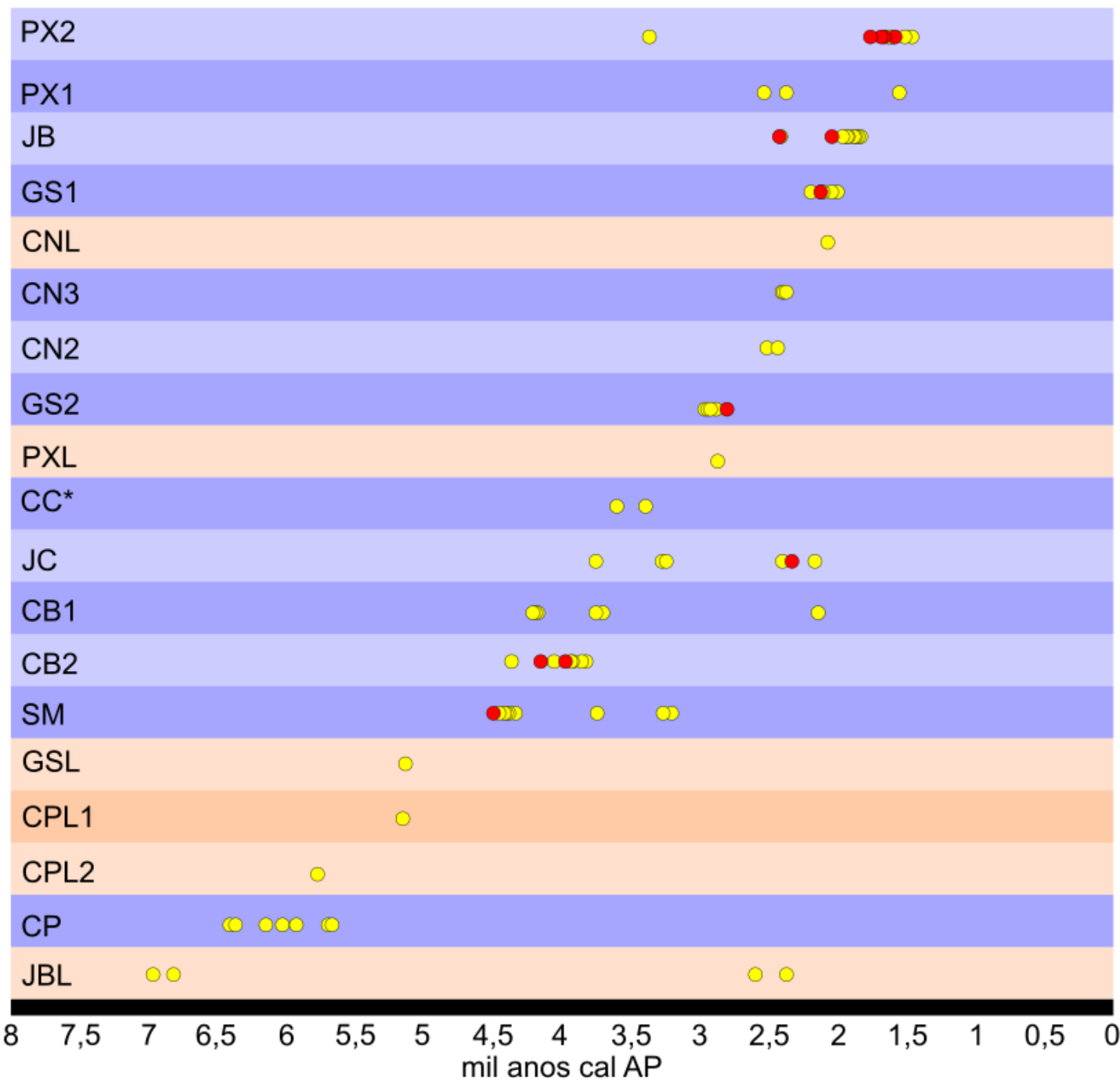

Figura 38. Distribuição das idades obtidas via ${ }^{14} \mathrm{C}$ AMS de conchas de $A$. brasiliana (círculos amarelos) e de carvões (círculos vermelhos), nos depósitos paleolagunares (linhas rosa) e nos sambaquis (linhas azuis). Os pontos representam a mediana do intervalo de idade calibrada. 
O histograma de distribuição de frequências de idades médias calibradas das conchas e carvões (Figura 39) permite observar mistura entre diferentes populações de idades, com aumento de frequência das idades mais recentes bastante marcado, no caso dos sambaquis, enquanto que as idades das conchas dos depósitos paleolagunares, apesar de representarem apenas pequena parcela da análise, distribuem-se de forma discreta e relativamente homogênea dentro de todo espectro temporal.

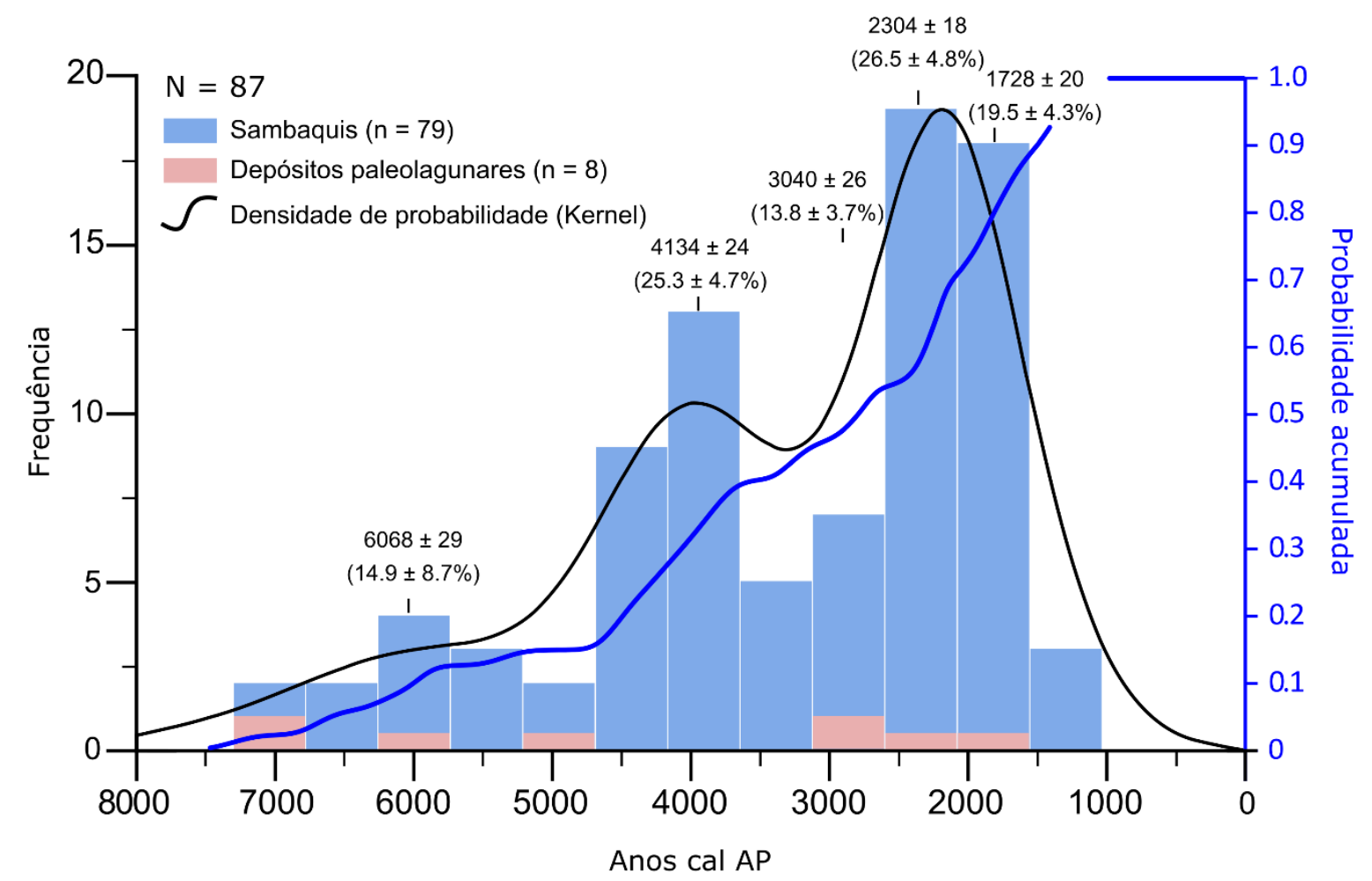

Figura 39. Histograma de idades ${ }^{14} \mathrm{C}$ obtidas em carvões de sambaquis e em conchas de sambaquis e de depósitos paleolagunares.

A partir dos dados integrados de ambos os depósitos, que refletem a tendência das idades de sambaquis, é possível distinguir três picos de populações distintas, como destacado pelo histograma e na curva de densidade de probabilidade (tipo Kernel) na Figura 40. Os picos distribuem-se espaçados de maneira homogênea, correspondendo aproximadamente aos intervalos de 6000, 4000 e 2000 anos $( \pm 1000$ cal AP), com aumento de frequência relativa na população de idades mais jovens.

Além desses três picos, foram obtidos ainda agrupamentos de idades com base em modelos de mistura de população utilizando cálculos não paramétricos disponíveis no software Density Plotter ${ }^{\oplus}$. Esses agrupamentos, também apresentados na Figura 40 , são cinco. O primeiro deles, coincidente com o pico de idades mais antigas, resulta 
em uma idade média de $6068 \pm 29$ anos, e corresponde a cerca de 15\% das análises. O segundo agrupamento, também correspondente a um pico bem expressivo no histograma, resulta em uma idade média de $4134 \pm 24$ anos, representando cerca de um quarto $(25 \%)$ do total de análises. Outro agrupamento descriminado com base no modelo de mistura de populações é representado por uma zona de baixa frequência de idades, entre os dois picos principais. Esse terceiro agrupamento corresponde à idade média de $3040 \pm 26$ anos, e representa cerca de 14\% das análises. Já o pico principal de idades é decomposto em dois agrupamentos distintos: o mais velho ocorre em $2304 \pm 18$ anos, e corresponde a cerca de $27 \%$ das análises; e o mais jovem resulta em uma idade média de $1728 \pm 20$ anos e representa $20 \%$ dos resultados obtidos.

O fato de os picos e os agrupamentos de idades serem cada vez mais expressivos quanto mais jovens pode estar associado ou ao processo de amostragem (viés estatístico) ou ao aumento real na frequência de sítios cada vez mais recentes. Para testar a hipótese de viés amostral, a estratégia de coleta de dados utilizada foi analisada quanto à variação da média, mediana e desvio padrão das idades, em cada sítio (Figura 40). Geralmente os resultados médios e a mediana por sítio são correspondentes, com poucas exceções, como no caso dos sítios PX1 e SM, nos quais existe o predomínio de idades mais jovens ou mais velhas que a média, respectivamente. Adicionalmente, os números de análises por sítio não diferem abruptamente e nem apresentam correlação direta com as idades obtidas. A Figura 40 mostra os sítios organizados em ordem cronológica, de tal forma que é possível observar ainda as sobreposições de faixas de idades correspondentes às barras de desvio padrão. As faixas de variação podem corresponder, de maneira simplificada, à "duração" de cada sítio ao longo do tempo (a rigor, duração do locus amostrado). Estas faixas ocorrem principalmente no intervalo de idades entre 3000 e 1500 anos cal AP. Este conjunto de características indica que não houve viés na estratégia de amostragem de cada locus, em si. Por outro lado, não se pode descartar a possibilidade de ter havido viés na escolha das seções amostradas, já que se deu preferência para seções que chegavam até a superfície topográfica e que, portanto, privilegiavam, senão o final da ocupação do sítio, pelo menos o final da ocupação daquele locus. 


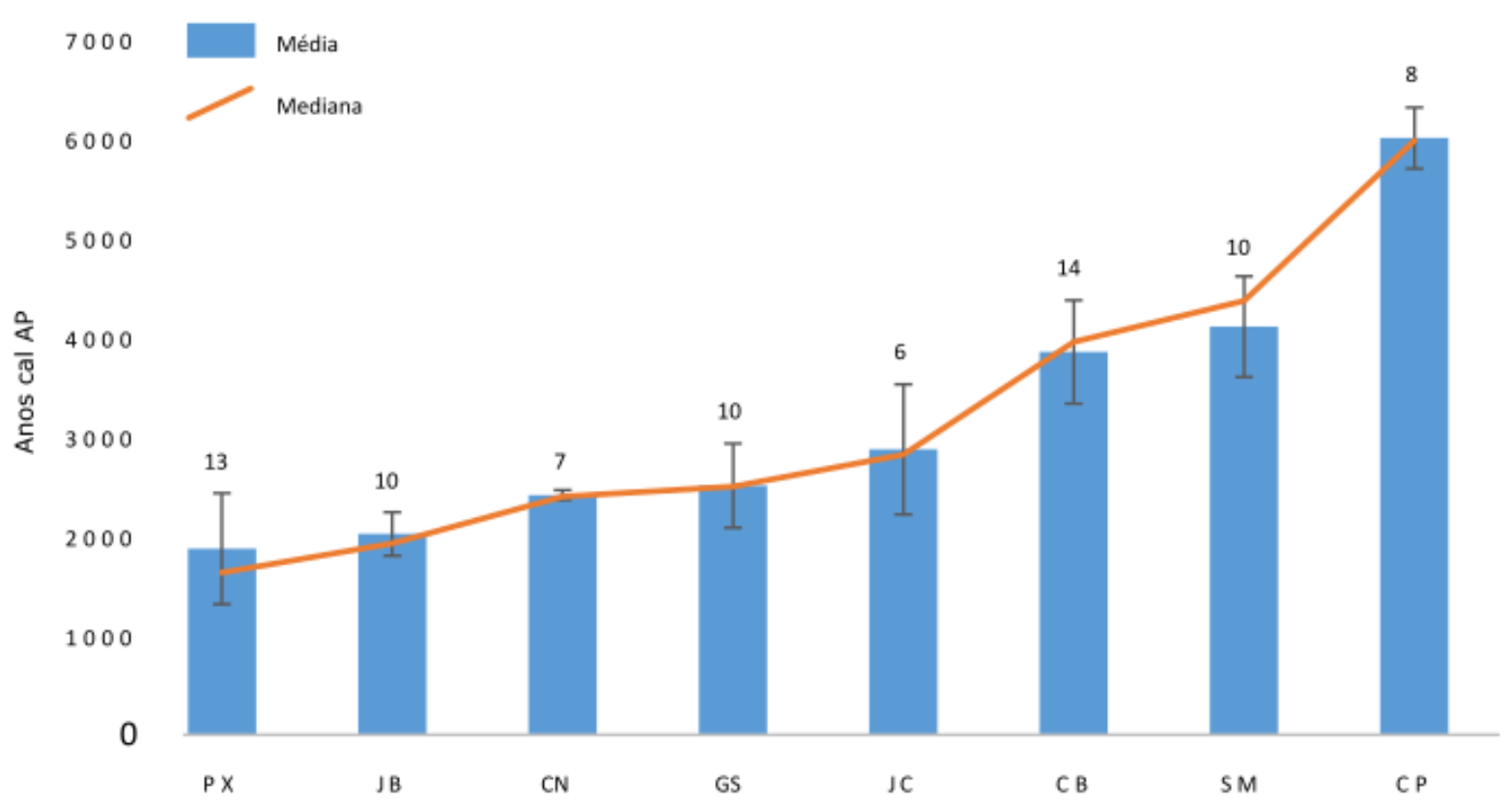

Figura 40. Sambaquis organizados em sequência cronológica, baseado nas médias de idades obtidas em cada sítio. Notar as coincidências entre média e mediana na maioria dos casos. Notar também como as barras de desvio padrão dos diferentes sítios apresentam mais sobreposição entre si nas idades mais jovens.

\subsection{Fácies}

Foram identificadas 11 fácies nas seis trincheiras dos depósitos paleolagunares, sintetizadas na Tabela 4 e ilustradas na Figura 41.

De modo geral, nota-se tendência de granodecrescência ascendente do sedimento paleolagunar; na base da sequência, atingindo as idades mais antigas, ocorrem fácies de assembleias fossilíferas compostas por conchas articuladas e em posição de vida (CiqA, LaCpv, ACpv, CiALmo); sobre estas ocorrem fácies de conchas retrabalhadas, com mistura de valvas inteiras e fragmentadas, com aumento proporcional de valvas fragmentadas (fácies CqA, Cq, CqALmo, Ciqg, LAmoCiq) para o topo; a sucessão é encerrada com fácies mais lamosas, sem conchas (A, ALmo).

À exceção de CPL2, todas as trincheiras estudadas apresentaram fácies de conchas retrabalhadas, inteiras e quebradas sobrepostas pela fácies lamosa sem conchas. As fácies contendo assembleias de conchas preservadas em posição de vida ocorrem, exclusivamente, nos depósitos JBL, GSL e CPL2; nos dois primeiros, encontram-se à profundidade de cerca de $100 \mathrm{~cm}$; já em CPL2, ocorre junto à superfície até a profundidade de $50 \mathrm{~cm}$. Estas diferenças de CPL2 em relação às demais seções paleolagunares devem-se provavelmente ao fato de, neste local, ter havido decapeamento artificial do solo, com retirada da fácies superior. 
Tabela 4. Relação e descrição das fácies observadas nos depósitos paleolagunares.

\begin{tabular}{|c|l|}
\hline Fácies & \multicolumn{1}{c|}{ Descrição das fácies } \\
\hline A & Areia fina a muito fina cinza, aparentemente maciça \\
\hline ACpv & $\begin{array}{l}\text { Areia fina a média, aparentemente clasto-suportada, com conchas inteiras, } \\
\text { inclusive articuladas e em posição de vida }\end{array}$ \\
\hline ALmo & Areia lamosa preta \\
\hline CiALmo & $\begin{array}{l}\text { Cascalho conchífero clasto-suportado de conchas dominantemente inteiras, } \\
\text { com matriz de areia lamosa preta }\end{array}$ \\
\hline CiqA & $\begin{array}{l}\text { Cascalho conchífero clasto-suportado com conchas quebradas e } \\
\text { dominantemente inteiras, inclusive articuladas, e matriz arenosa }\end{array}$ \\
\hline Ciqg & $\begin{array}{l}\text { Cascalho conchífero clasto-suportado, com domínio de conchas inteiras e } \\
\text { gradação normal evidente (aumento da proporção de conchas quebradas para } \\
\text { o topo) }\end{array}$ \\
\hline Cq & \begin{tabular}{l} 
Cascalho arenoso com bioclastos dominantemente quebrados \\
\hline CqA
\end{tabular} $\begin{array}{l}\text { Cascalho conchífero clasto-suportado com conchas dominantemente } \\
\text { fragmentadas e matriz arenosa }\end{array}$ \\
\hline CqALmo & $\begin{array}{l}\text { Cascalho conchífero clasto-suportado de conchas dominantemente } \\
\text { fragmentadas com matriz de areia lamosa preta }\end{array}$ \\
\hline LACpv & $\begin{array}{l}\text { Lama arenosa com conchas dominantemente inteiras, articuladas, em posição } \\
\text { de vida }\end{array}$ \\
\hline LAmoCiq & \begin{tabular}{l} 
Lama arenosa turfosa com conchas quebradas e inteiras esparsas \\
\hline
\end{tabular} \\
\hline
\end{tabular}




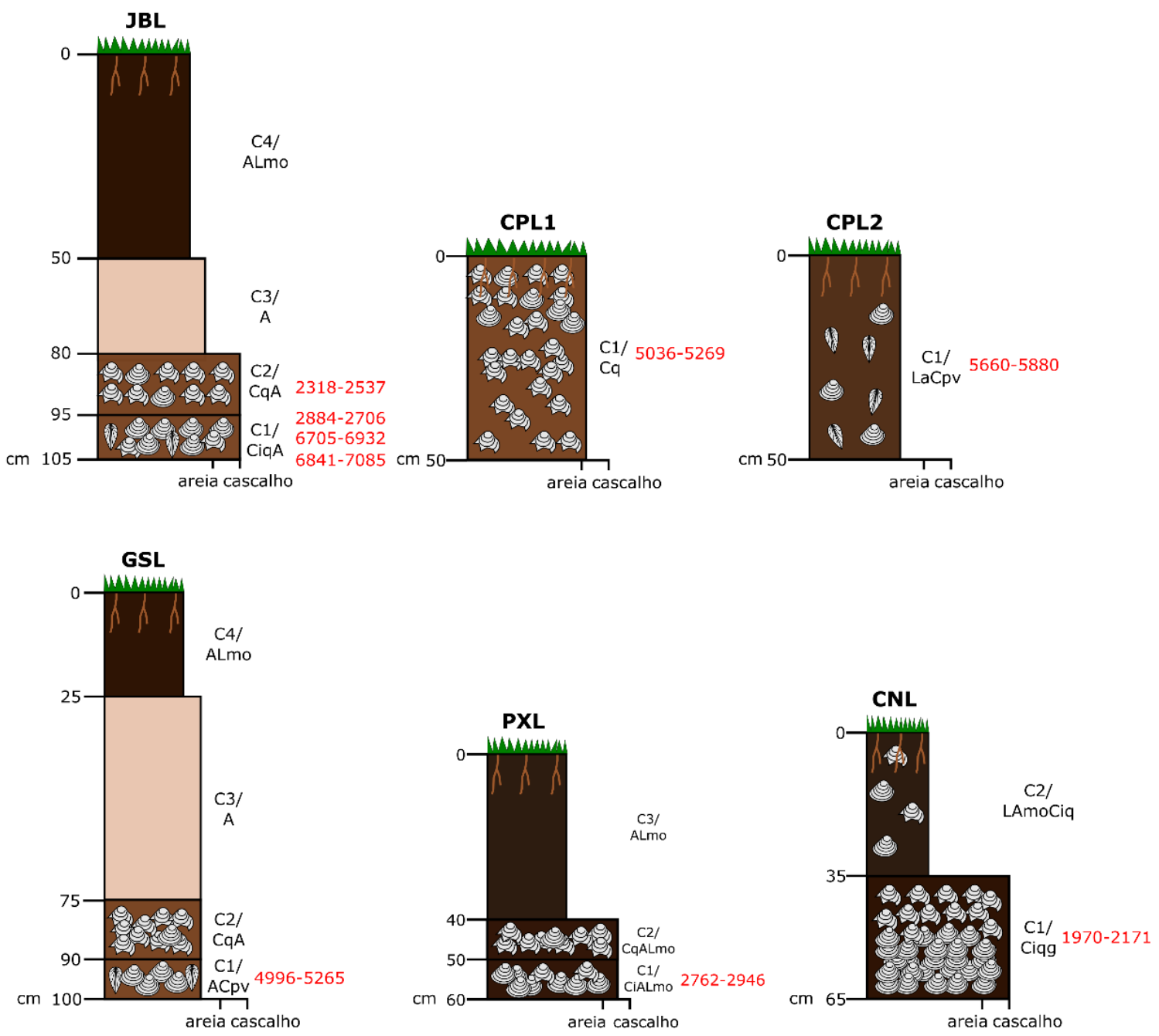

Figura 41. Seções colunares dos depósitos paleolagunares. Idades das conchas em vermelho.

Nas 13 seções dos sambaquis, foram identificadas 32 fácies, sintetizadas na Tabela 5 e ilustrados nas figuras 43 a 55 .

Tabela 5. Relação e descrição das fácies observadas nos sambaquis.

\begin{tabular}{|c|l|}
\hline Fácies & \multicolumn{1}{c|}{ Descrição da fácies } \\
\hline A & Areia fina a média cinza claro \\
\hline AC & $\begin{array}{l}\text { Cascalho conchífero suportado pela matriz arenosa marrom incoesa (teor de } \\
\text { conchas estimado em volume superior a 30\%) }\end{array}$ \\
\hline AAC & $\begin{array}{l}\text { Areia argilosa marrom escuro a preto (rica em M.O.?) com conchas esparsas } \\
\text { dominantemente inteiras e sutil clareamento gradual para cima }\end{array}$ \\
\hline ACiq & $\begin{array}{l}\text { Cascalho conchífero matriz-suportado, com matriz arenosa incoesa com } \\
\text { conchas inteiras e fragmentadas e lâminas centimétricas de conchas inteiras }\end{array}$ \\
\hline AcmC & $\begin{array}{l}\text { Cascalho conchífero matriz-suportado de conchas moídas com matriz arenosa } \\
\text { incoesa }\end{array}$ \\
\hline Al & $\begin{array}{l}\text { Areia fina bem selecionada coesa (cimento argilo orgânico ferruginoso) com } \\
\text { líticos subdecimétricos esparsos sem conchas }\end{array}$ \\
\hline Alfo & Areia lamosa preta rica em ossos quebrados e matéria orgânica ("capa preta") \\
\hline ALmo & Areia lamosa preta \\
\hline
\end{tabular}




\begin{tabular}{|c|c|}
\hline Fácies & Descrição da fácies \\
\hline CA & Cascalho conchífero clasto-suportado de matriz arenosa marrom incoesa \\
\hline CabAcm & $\begin{array}{l}\text { Cascalho clasto-suportado por conchas de Anomalocardia brasiliana com } \\
\text { matriz de conchas moídas }\end{array}$ \\
\hline CAcm & $\begin{array}{l}\text { Cascalho clasto-suportado fino }(<5 \mathrm{~mm}) \text { e conchas moídas (aparentemente } \\
\text { ostras) com impregnação por película marrom (possivelmente orgânica) }\end{array}$ \\
\hline CAcm & $\begin{array}{l}\text { Cascalho conchífero clasto-suportado, com arcabouço de conchas moídas, } \\
\text { matriz arenosa coesa }\end{array}$ \\
\hline CAfo & Cascalho clasto-suportado com matriz com farinha de ossos (amarela) \\
\hline CAmo & Cascalho clasto-suportado com matriz arenosa preta \\
\hline Ccm & Cascalho fino clasto-suportado dominado por farinha de concha \\
\hline CcmLmo & $\begin{array}{l}\text { Cascalho fino clasto-suportado, com conchas moídas, com matriz argilo- } \\
\text { orgânica e conchas inteiras dispersas }\end{array}$ \\
\hline $\mathrm{Ci}$ & Cascalho conchífero clasto-suportado com conchas dominantemente inteiras \\
\hline CiA & $\begin{array}{l}\text { Cascalho conchífero clasto-suportado com predomínio de conchas inteiras, } \\
\text { matriz arenosa, estratificação incipiente na base }\end{array}$ \\
\hline CiALmo & $\begin{array}{l}\text { Cascalho clasto-suportado dominado por conchas inteiras de Anomalocardia e } \\
\text { presença subordinada de ostras, com matriz areno-argilosa rica em matéria } \\
\text { orgânica }\end{array}$ \\
\hline CiAmo & $\begin{array}{l}\text { Cascalho conchífero clasto-suportado de conchas inteiras com matriz argilo- } \\
\text { orgânica }\end{array}$ \\
\hline CiqLmo & $\begin{array}{l}\text { Cascalho clasto-suportado fino }(<5 \mathrm{~mm}) \text { de conchas quebradas e impregnação } \\
\text { por material argilo-orgânico preto }\end{array}$ \\
\hline CLAmo & Cascalho clasto-suportado rico em lama arenosa preta (com matéria orgânica) \\
\hline Cmo & $\begin{array}{l}\text { Cascalho clasto-suportado com película preta (argilo-orgânica) revestindo as } \\
\text { conchas }\end{array}$ \\
\hline CotAcm & $\begin{array}{l}\text { Cascalho clasto-suportado por conchas de ostras com matriz de conchas } \\
\text { moídas }\end{array}$ \\
\hline CotAfo & $\begin{array}{l}\text { Conglomerado sustentado por conchas de ostras (até } 12 \mathrm{~cm} \text { ) com ossos } \\
\text { fragmentados ("matriz amarelada") }\end{array}$ \\
\hline CotALmo & $\begin{array}{l}\text { Cascalho clasto-suportado com conchas inteiras de ostras, com matriz areno- } \\
\text { argilosa rica em matéria orgânica }\end{array}$ \\
\hline CotAmo & $\begin{array}{l}\text { Cascalho clasto-suportado grosso ( }>5 \mathrm{~mm}) \text { dominado por conchas de ostras } \\
\text { inteiras com matriz areno-argilosa marrom escura a preta (rico em M.O.?) }\end{array}$ \\
\hline $\mathrm{CqA}$ & $\begin{array}{l}\text { Cascalho conchífero clasto-suportado com conchas predominantemente } \\
\text { fragmentadas e matriz arenosa incoesa }\end{array}$ \\
\hline CqALmo & $\begin{array}{l}\text { Cascalho conchífero clasto-suportado de conchas dominantemente } \\
\text { fragmentadas com matriz de areia lamosa preta }\end{array}$ \\
\hline Cqmo & $\begin{array}{l}\text { Cascalho clasto-suportado fino }(<5 \text { a } 10 \mathrm{~mm}) \text { de conchas quebradas, com } \\
\text { ostras inteiras esparsas e impregnação por material argilo-orgânico preto }\end{array}$ \\
\hline LAmo & Lama arenosa rica em matéria orgânica preta, subdecimétrica \\
\hline LAmoCiq & $\begin{array}{l}\text { Cascalho conchífero lenticular suportado por matriz argilo-arenosa com } \\
\text { conchas fragmentadas e inteiras }\end{array}$ \\
\hline
\end{tabular}

Embora sambaquis sejam dominantemente compostos por fácies conchíferas, estas diferem, quanto à granulometria, composição taxonômica e atributos tafonômicos.

Fácies clasto-suportadas de conchas de $A$. brasiliana dominantemente inteiras, em matriz arenosa (AAC, $\mathrm{CiA}, \mathrm{Ci}, \mathrm{CA}, \mathrm{CAmo})$, ocorrem nos sambaquis Caipora, Santa 
Marta 2, Cabeçuda, Carniça 3 e Garopaba do Sul (Figuras 42 a 47), enquanto fácies clasto-suportadas de conchas de ostras inteiras, em matriz de conchas moídas (Cqmo, CotAmo, CotALmo), encontram-se nos sambaquis Caipora e Jaboticabeira 1 (Figuras 42 e 49).

Fácies cascalhosas de conchas inteiras suportadas pela matriz arenosa (ACiq, AC, LAmoCiq) foram descritas nos sambaquis Santa Marta 2, Cabeçuda e Garopaba do Sul (Figuras 43, 44, 45 e 47). Já as cascalho-suportadas de conchas inteiras com matriz lamosa (CiALmo, CiAmo, CLAmo, Cmo) foram identificadas no Jaboticabeira 1, no Carniça 1 e no Perrixil (Figuras 49 a 53).

Fácies cascalhosas de conchas dominantemente quebradas ( $\mathrm{CqA}$, CiqLmo) ocorrem nos sambaquis Caipora, Santa Marta 2 e Jaboticabeira 2 (Figuras 42, 43 e 54); e as de cascalho conchífero fino em matriz de conchas moídas (CAcm, AcmC, $\mathrm{Ccm}, \mathrm{Ccm} L \mathrm{mo}, \mathrm{CaAcm}$ ), nos sambaquis Jaboticabeira 1, Perrixil e Jaboticabeira 2 (Figuras 49, 52, 53 e 54).

Fácies compostas de cascalho conchífero em matriz de ossos moídos (CAfo, Cio, CotAfo-CotAcm) ocorrem nos sambaquis Carniça 3 e Perrixil (Figuras 46, 52 e 53).

Finalmente, a única fácies composta por areia lamosa em matriz de ossos moídos (Afo) registrada ocorre no topo da sucessão do sambaqui Jaboticabeira 2 (Figura 54). 

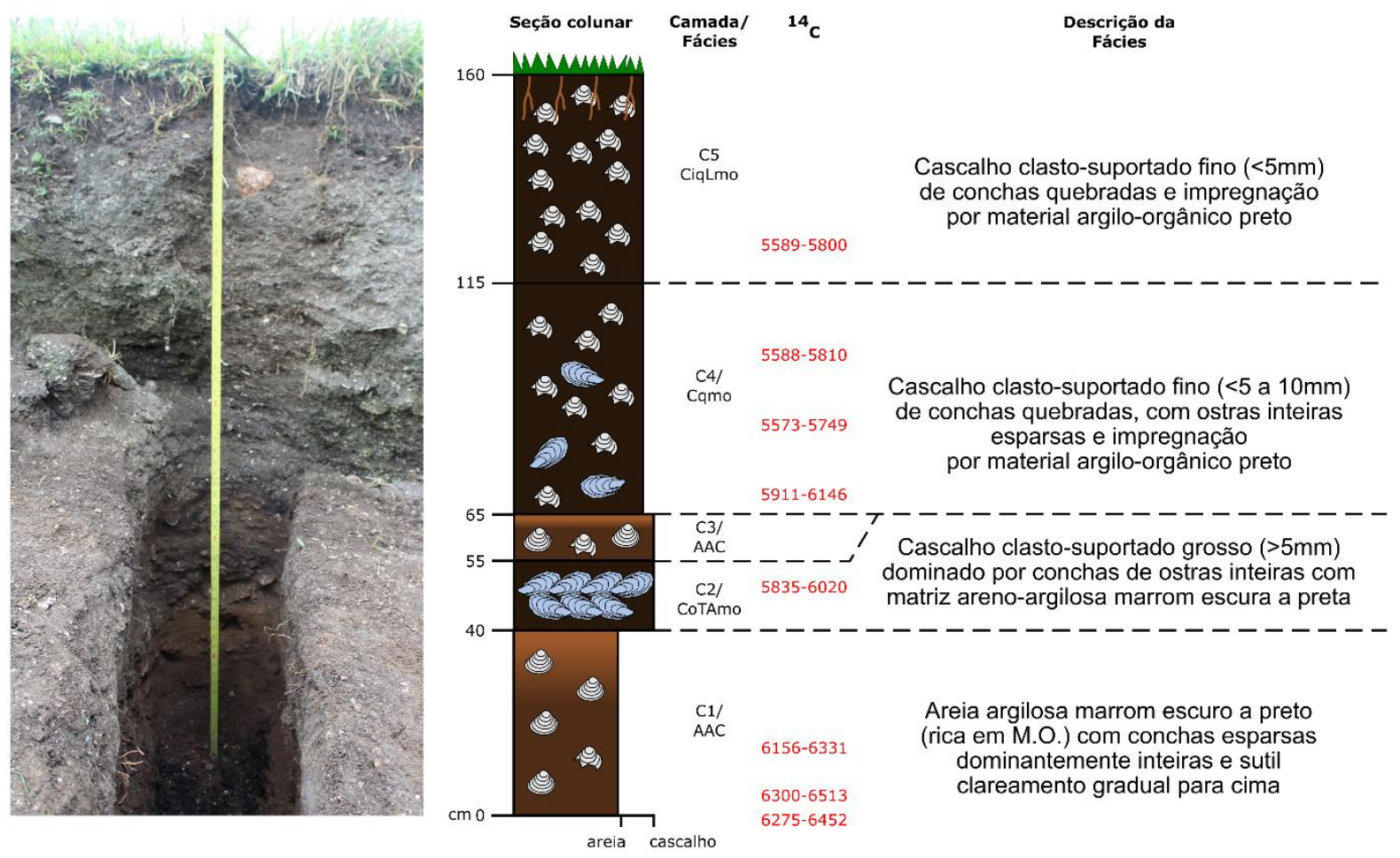

Figura 42. Seção colunar e descrição faciológica do sambaqui Caipora com a distribuição das idades das conchas (em vermelho).
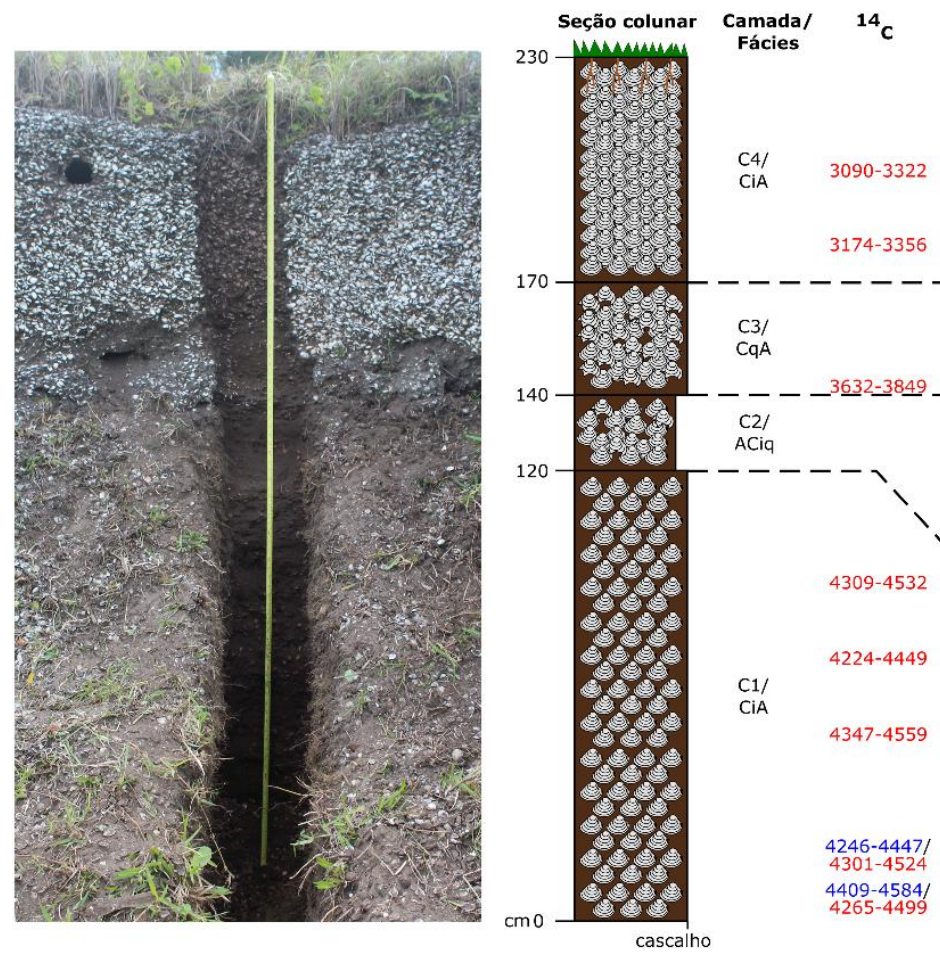

Figura 43. Seção colunar e descrição faciológica do sambaqui Santa Marta 2 com a distribuição das idades das conchas (em vermelho) e dos carvões (em azul). 

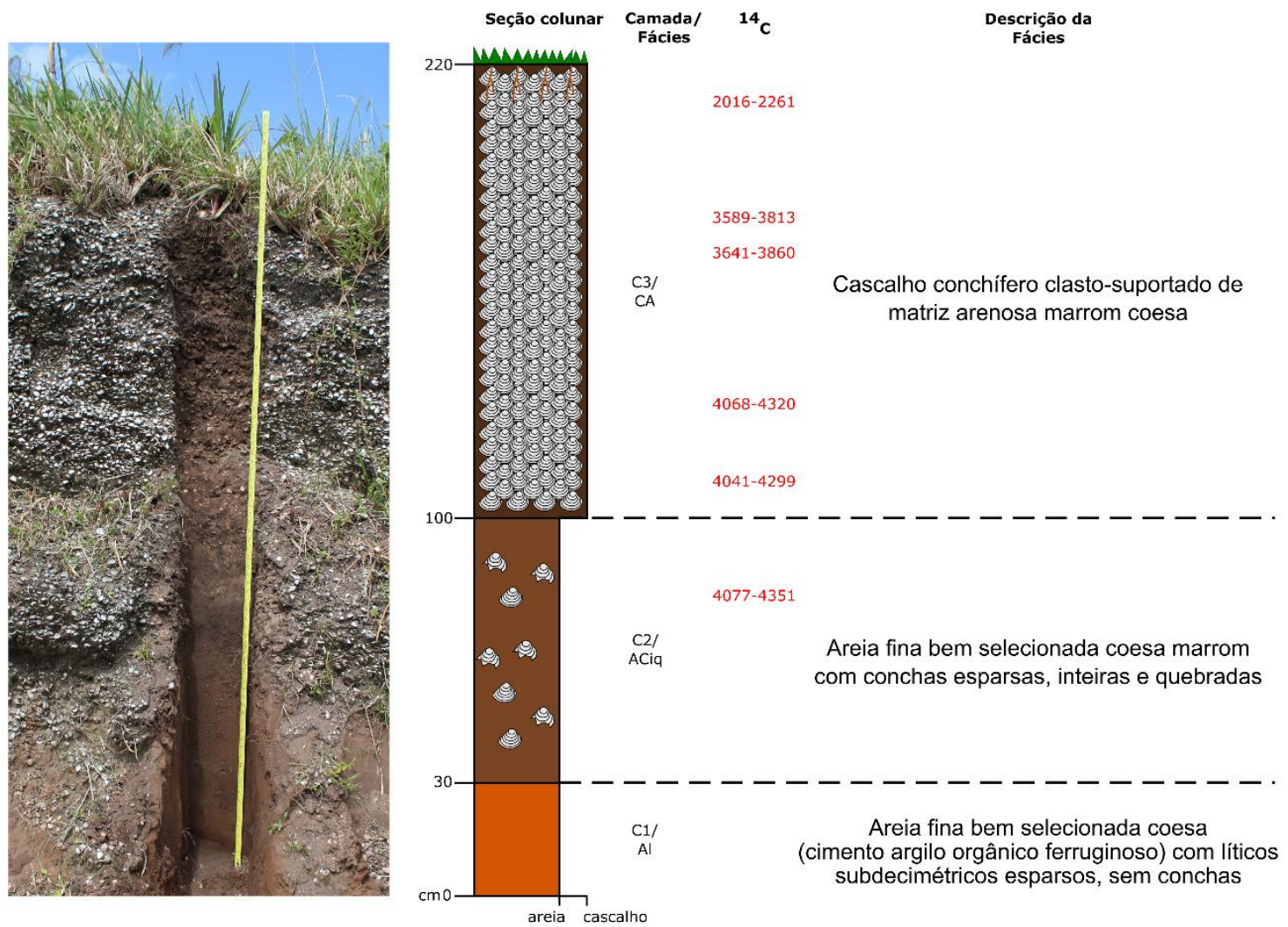

Figura 44. Seção colunar e descrição faciológica da Seção 1 do sambaqui Cabeçuda com a distribuição das idades das conchas (em vermelho).
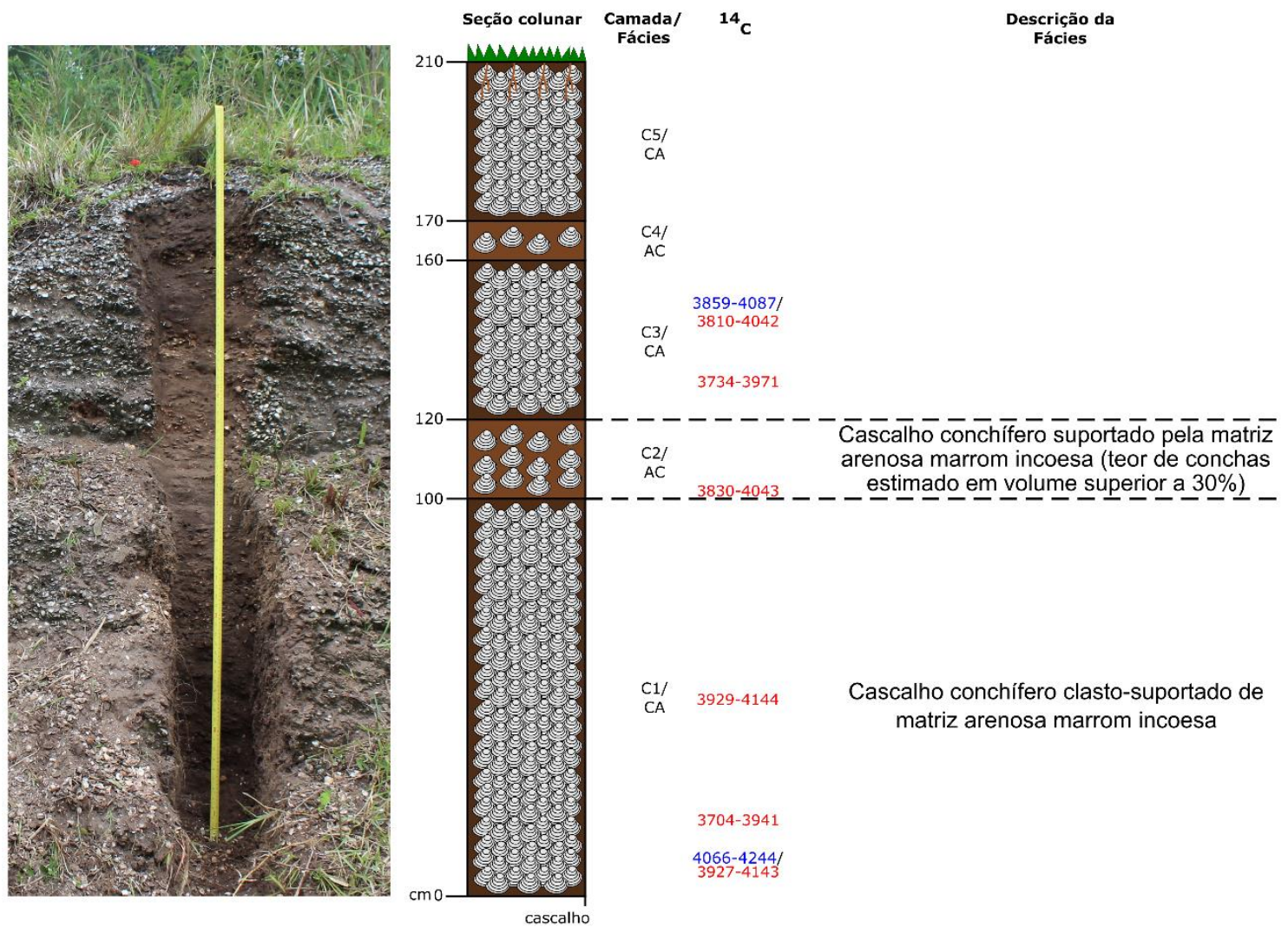

Figura 45. Seção colunar e descrição faciológica da Seção 2 do sambaqui Cabeçuda com a distribuição das idades das conchas (em vermelho) e dos carvões (em azul). 

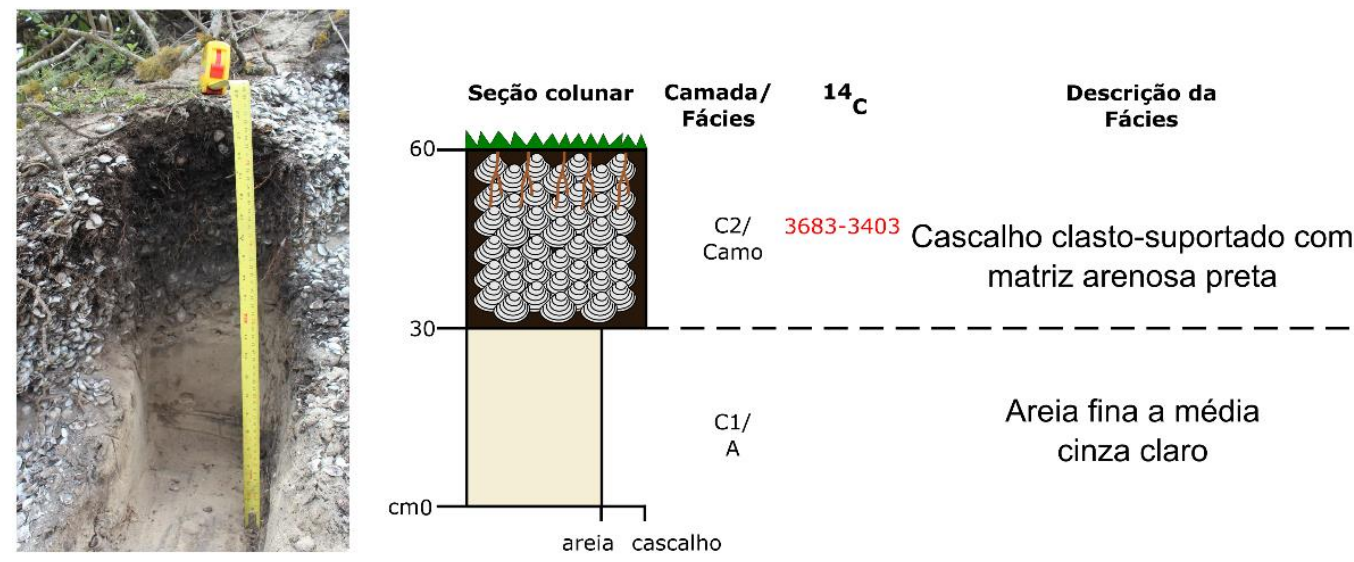

Figura 46. Seção colunar e descrição faciológica do sambaqui Carniça $3 \mathrm{com}$ a idade de uma concha (em vermelho) obtida por Giannini et al. (2010).
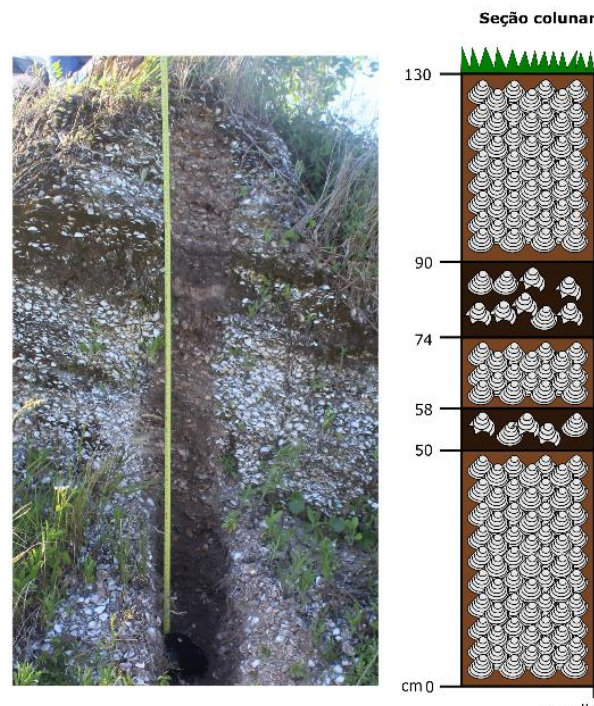

Camada/
Fácies

Descrição da

(1)

${ }^{14} \mathrm{c}$

$\stackrel{\mathrm{C} /}{\mathrm{Ci}} \quad 1989-2215$

$2042-2208 /$
$1952-2140$

C4/
LAmoCip

\section{$\mathrm{C} 3 / \mathrm{Ci}$}

$---1$

C2/ LAmocip

Cascalho conchifero lenticular suportado

por matriz argllo-arenosa com conchas

fragmentadas e inteiras

cascalho

\section{C1/}

Cascalho conchifero clasto-suportado

com conchas dominantemente inteiras

Figura 47. Seção colunar e descrição faciológica da Seção 1 do sambaqui Garopaba do Sul com a distribuição das idades das conchas (em vermelho) e dos carvões (em azul).
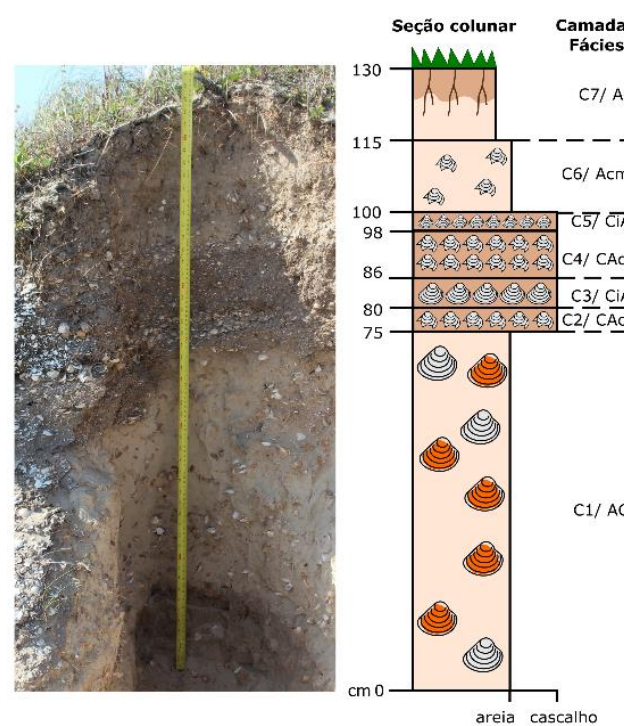

Fácies $\quad{ }^{14} \mathrm{c}$

Areia fina ligeiramente pedogeneizada

/ A

Cascalho conchifero matriz-suportado

de conchas moídas com matriz arenosa incoesa

Cascalho conchifero clasto-suportado

de conchas inteiras com matriz arenosa coesa

$\bar{C}$ ascalho conchifero clasto-suportado, com

arcabouço de conchas moídas e matriz arenosa coesa

2853-3063

Cascalho conchifero suportado por

matriz de areia fina, cinza claro, incoesa

2846-3053

Figura 48. Seção colunar e descrição faciológica da Seção 2 do sambaqui Garopaba do Sul com a distribuição das idades das conchas (em vermelho) e dos carvões (em azul). 

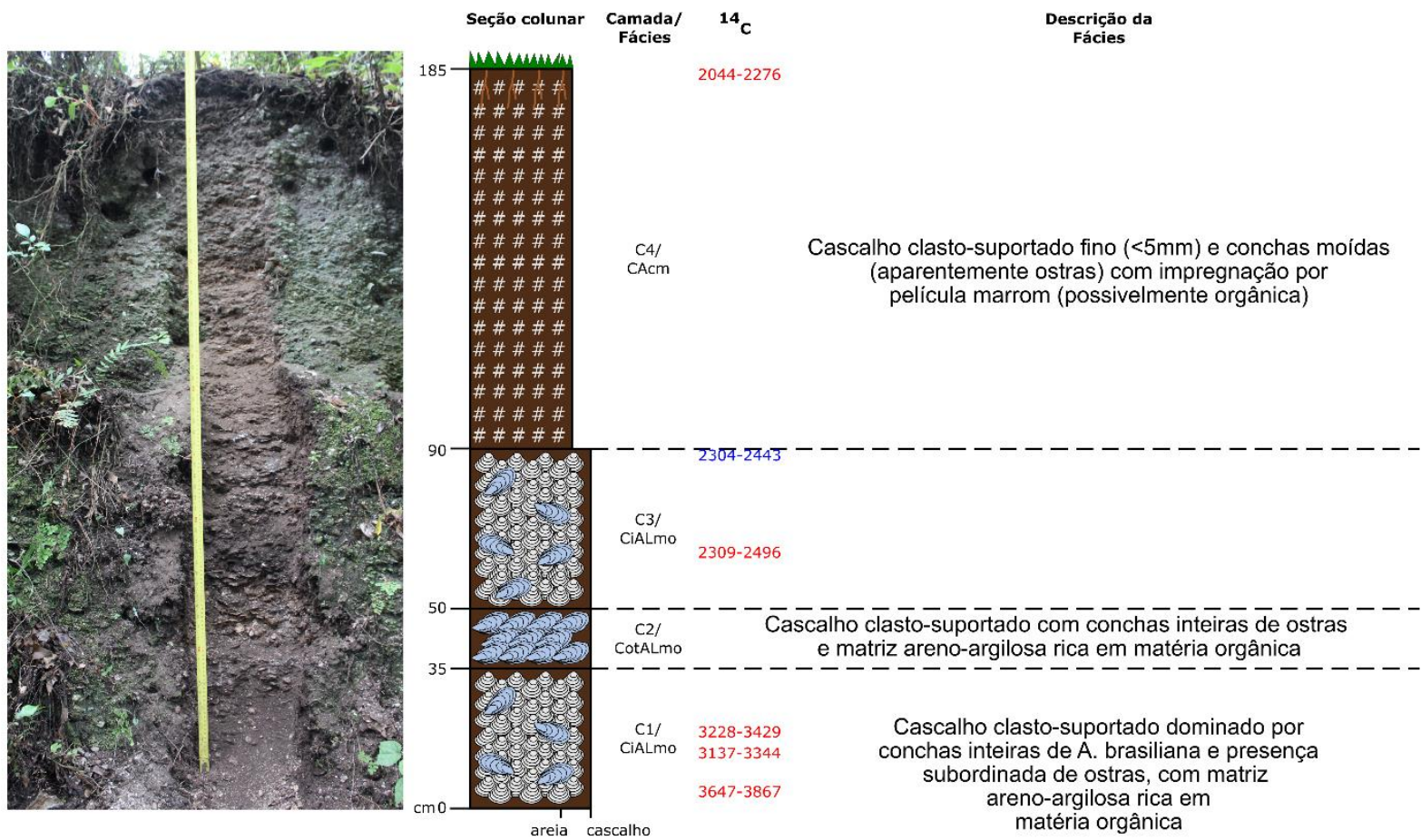

Figura 49. Seção colunar e descrição faciológica do sambaqui Jaboticabeira $1 \mathrm{com}$ a distribuição das idades das conchas (em vermelho) e dos carvões (em azul).
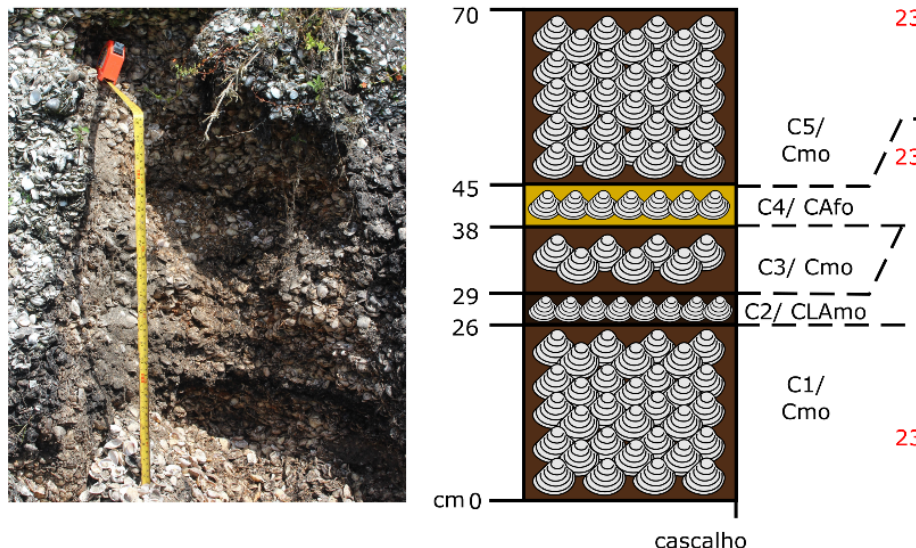

cascalho
Camada/
${ }^{14} \mathrm{C}$
Descrição da

Fácies

Figura 50. Seção colunar e descrição faciológica da Seção 2 do sambaqui Carniça 1 com a distribuição das idades das conchas (em vermelho). 

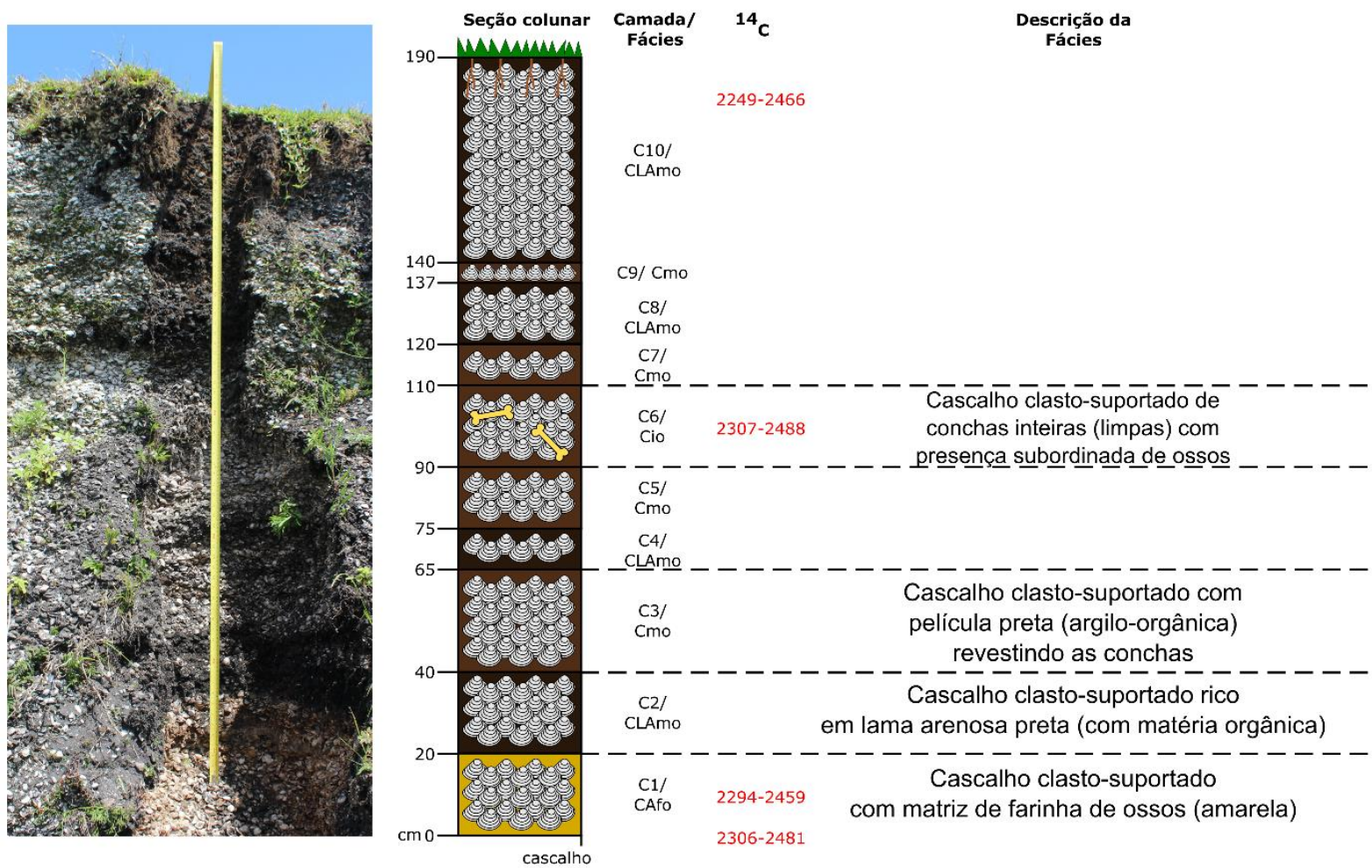

Figura 51. Seção colunar e descrição faciológica da Seção 3 do sambaqui Carniça $1 \mathrm{com}$ a distribuição das idades das conchas (em vermelho).

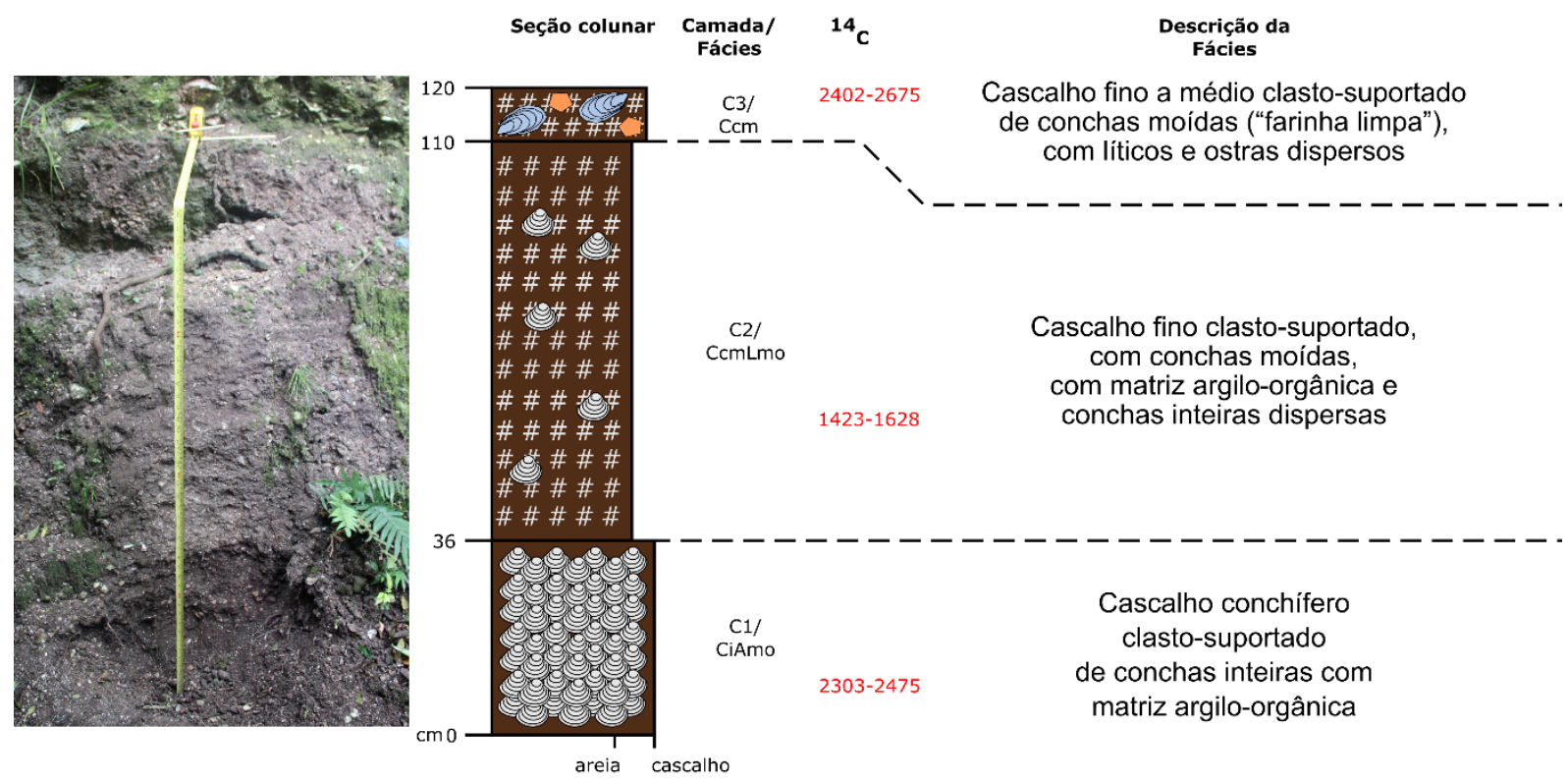

Figura 52. Seção colunar e descrição faciológica da Seção 1 do sambaqui Perrixil com a distribuição das idades das conchas (em vermelho). 

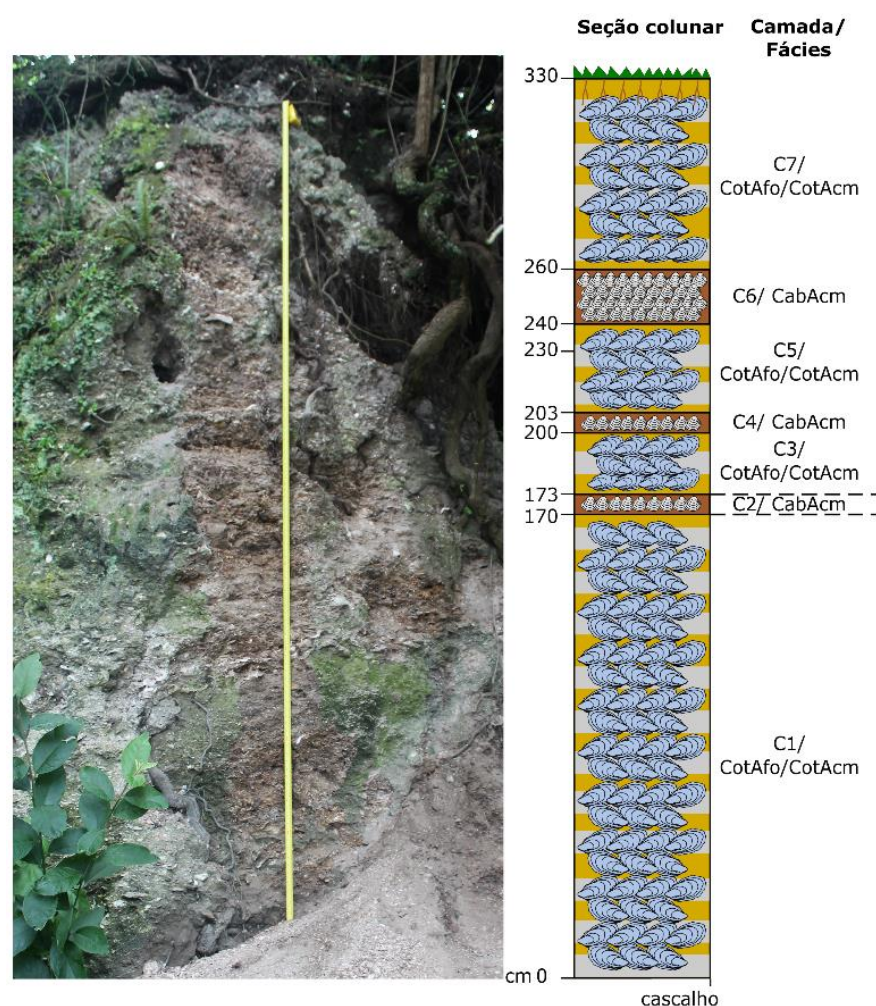

${ }^{14} \mathrm{C}$

Descrição da

Fácies

cascalho

Figura 53. Seção colunar e descrição faciológica da Seção 2 do sambaqui Perrixil com a distribuição das idades das conchas (em vermelho) e dos carvões (em azul).
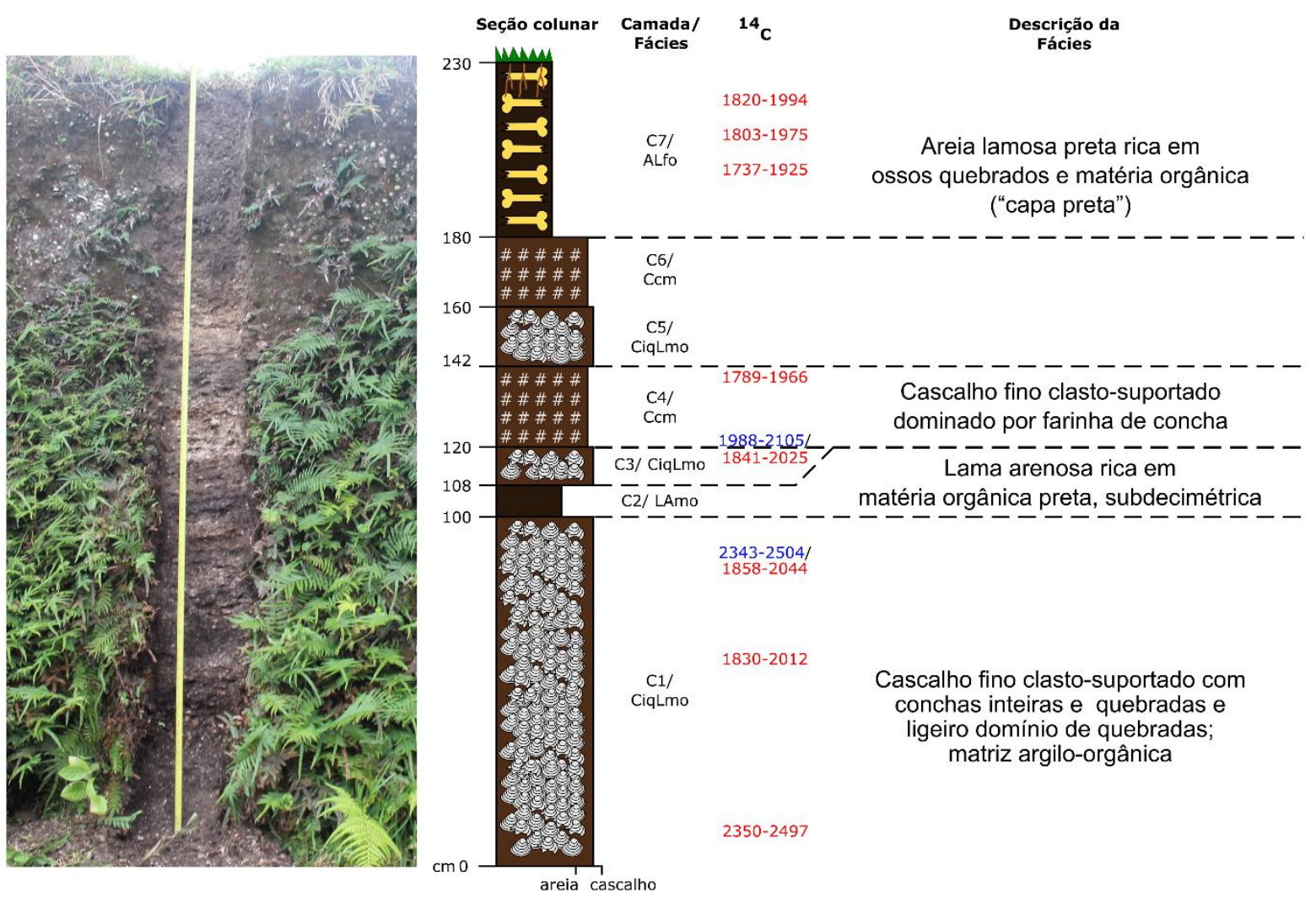

Figura 54. Seção colunar e descrição faciológica do sambaqui Jaboticabeira $2 \mathrm{com}$ a distribuição das idades das conchas (em vermelho) e dos carvões (em azul). 


\subsection{Granulometria}

Nos gráficos de variação, por amostra, de proporções de faixas granulométricas, é possível notar que nos depósitos paleolagunares (Figura 55) as três classes granulométricas mais importantes na constituição das fácies analisadas são areia fina e areia média, dominadas por sedimentos terrígenos, e seixos, representados por bioclastos e, mais raramente, conchas articuladas em posição de vida. Os pelíticos têm ocorrência subordinada (até 20\%), mas, ainda sim, estão presentes em cinco das oito amostras analisadas, com destaque para CPL2 e GSL.

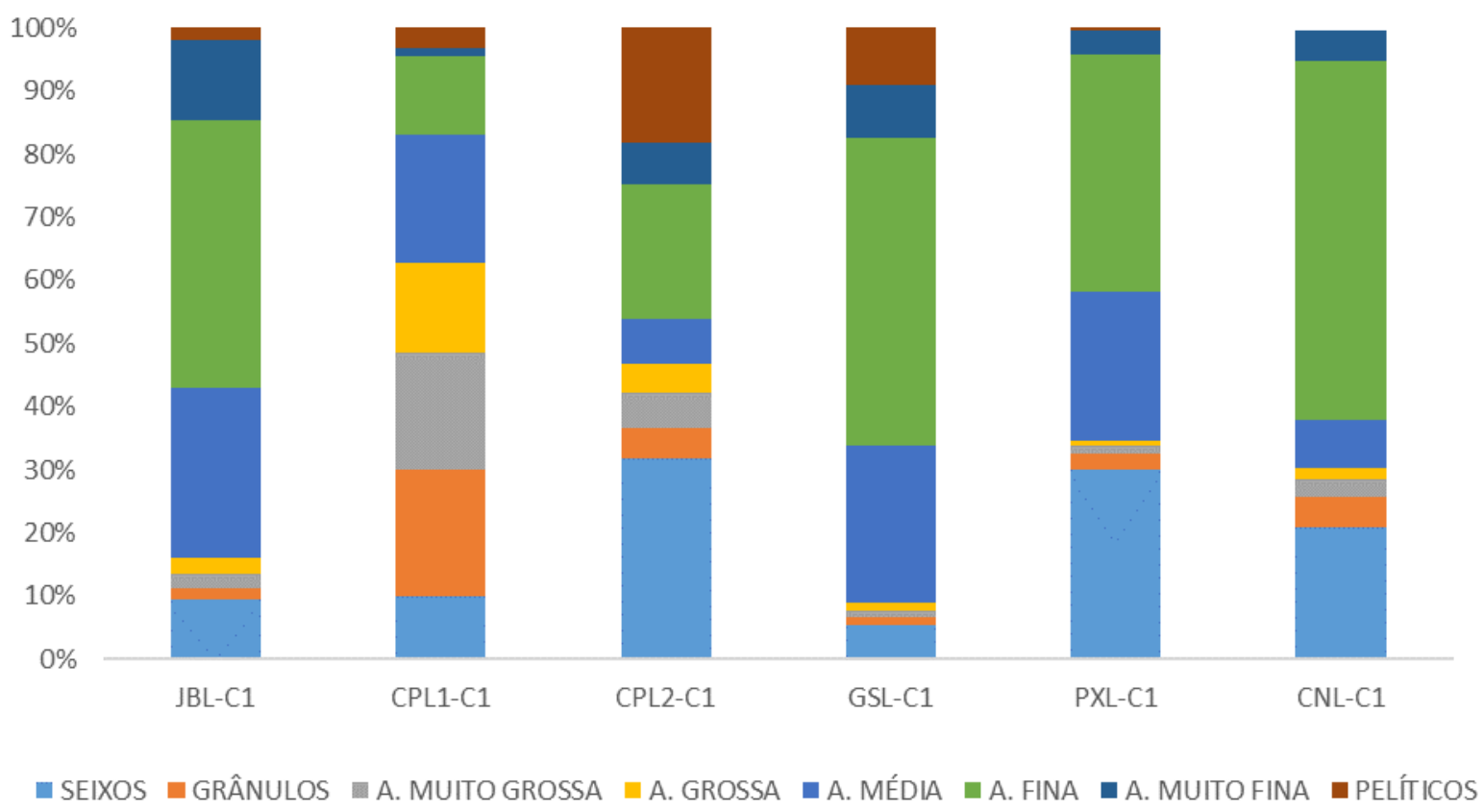

Figura 55. Relação das frações granulométricas observadas para cada fácies levantada nas paleolagunas. $\mathrm{N}=8$.

Já nas fácies dos sambaquis (Figura 56), as três faixas granulométricas mais bem representadas são cascalho, relacionado com a presença de conchas inteiras ou fragmentadas, areia fina, ligada sobretudo à presença de sedimento terrígeno paleolagunar ou eólico, e pelíticos, relacionados principalmente com matéria orgânica, lama terrígena e material finamente moído, como ossos, conchas e carvões. Numa única fácies, correspondente a CP-F1 (base do sambaqui Caipora), as frações areia e cascalho têm contribuição de sedimento terrígeno coluvionar. 


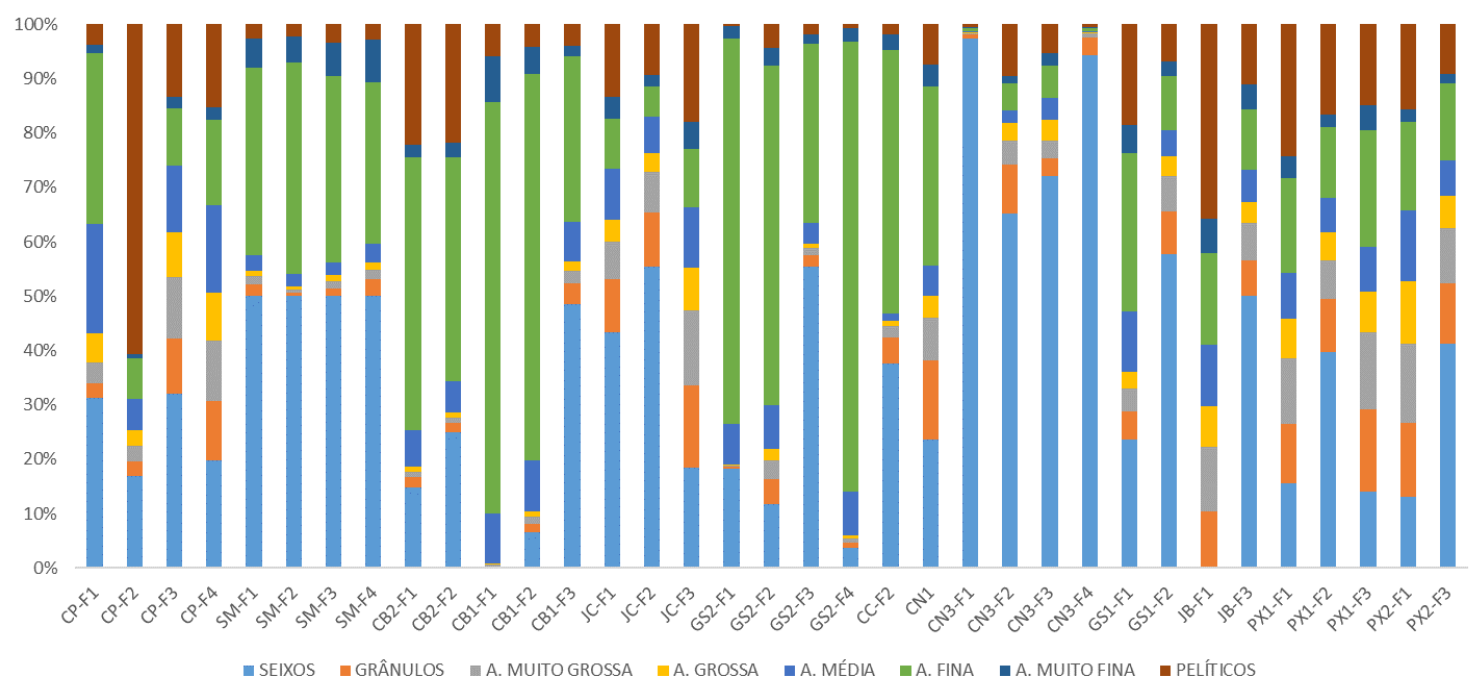

Figura 56. Relação das frações granulométricas observadas para cada fácies levantada nos sambaquis. $\mathrm{N}=35$.

Os diagramas em caixa da Figura 58 permitem observar que a variabilidade interamostral - representada pelo intervalo interquartis (extensão vertical da caixa) em areia média e areia muito fina é maior nos depósitos paleolagunares, enquanto que nas frações seixos, areia fina e pelíticos, em contraste, a variabilidade é maior nas fácies de sambaquis. Nas demais classes granulométricas (grânulos, areia grossa e areia muito grossa), as variabilidades dos depósitos paleolagunares e sambaquis são similares. Este resultado demonstra que a diferenciação das fácies dos depósitos paleolagunares entre si reside na proporção de areia fina (58\%), enquanto que nos sambaquis, essa diferença encontra-se na proporção relativa das duas classes extremas, seixos e pelíticos.

$\mathrm{Na}$ comparação entre sambaquis e paleolagunas, os primeiros diferem dos últimos pela proporção máxima de pelíticos muito mais elevada (cerca de $60 \%$ contra menos de 20\%) e pelos teores mais baixos de areia muito fina e principalmente de areia média (Figura 57). 


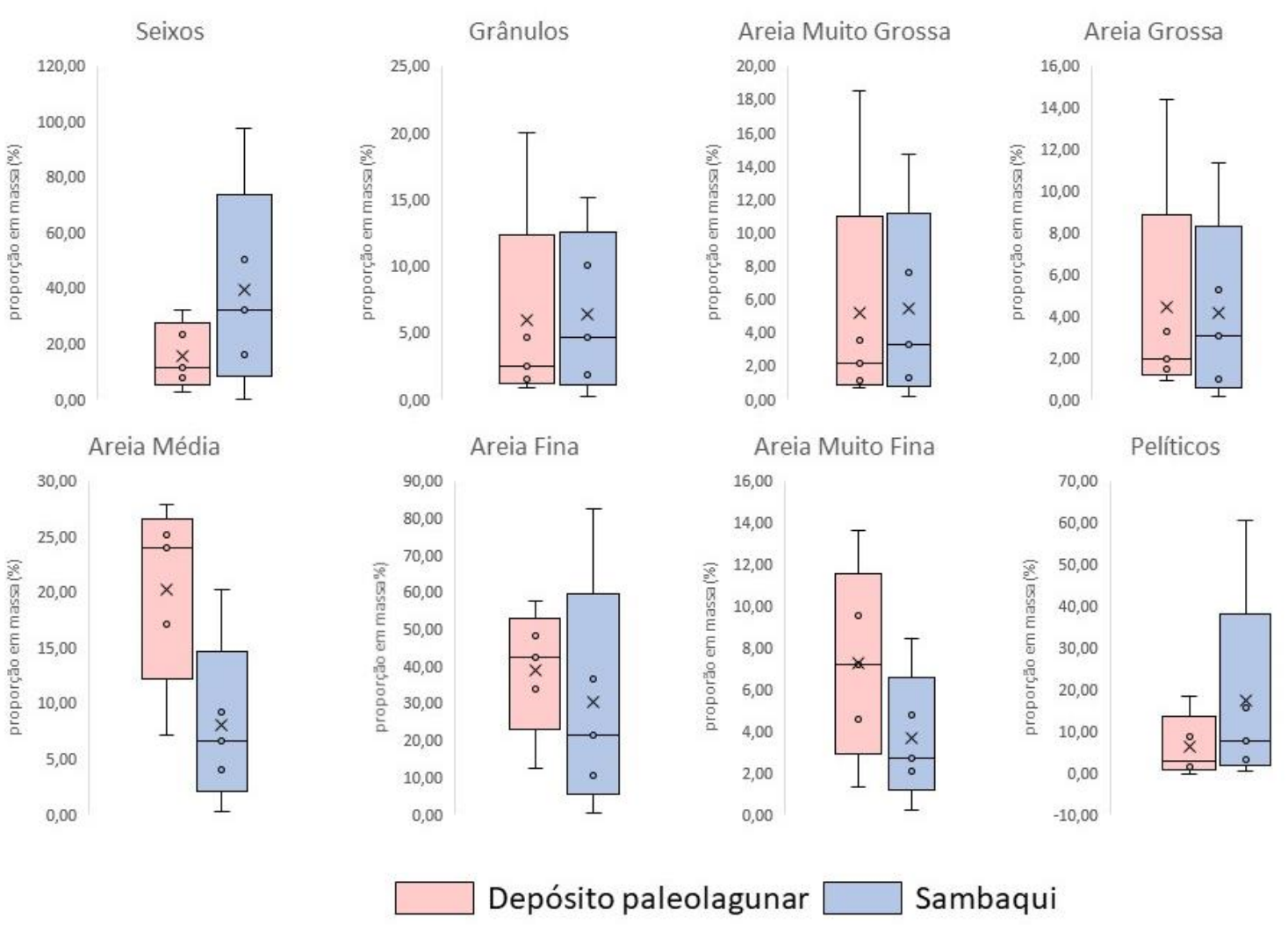

Figura 57. Gráficos de caixa (box-plot) comparando seixos, classes granulométricas de phi entre seixo e areia muito fina e teor de pelíticos total entre os depósitos paleolagunares e os sambaquis. $\mathrm{N}=43$.

Os gráficos de caixa para as quatro estatísticas da distribuição granulométrica (Figura 58) mostram maior intervalo interquartis e, portanto, maior variabilidade interamostral, nos sambaquis que nos depósitos paleolagunares, principalmente para tamanho médio, assimetria e curtose. O intervalo interquartis de tamanho médio de grão varia de 2,6 a -2,2 phi (areia fina a seixo), nos sambaquis, e de 2,1 a 0,2 phi (areia fina a areia grossa), nos depósitos paleolagunares. Para o desvio padrão, o intervalo interquartis varia de 2,2 a 3,9 phi, nos sambaquis, e de 2,1 a 3,3 phi, nas paleolagunas (Figura 19). Este resultado de desvio padrão permite afirmar que não existe diferença muito substancial entre a seletividade de granulações pelo processo construtivo de sambaquis e pelos processos naturais, o que poderia parecer surpreendente uma vez que se considere que a concha, na granulação cascalho, é quase sempre o componente dominante nos depósitos arqueológicos. Deve-se, no entanto, levar em conta a influência dos teores de lama em média mais elevados no sambaqui, o que acaba por reduzir os valores de desvio padrão. Sintoma disso é a maior presença de distribuições de assimetria positiva nos sambaquis, haja visto que 
o sinal positivo da assimetria relaciona-se como regra ao prolongamento da cauda de finos da distribuição granulométrica. O intervalo interquartis da assimetria varia de 1,8 a 4,1, nos sambaquis, e de -1,2 a 0,2, nas paleolagunas (Figura 58).
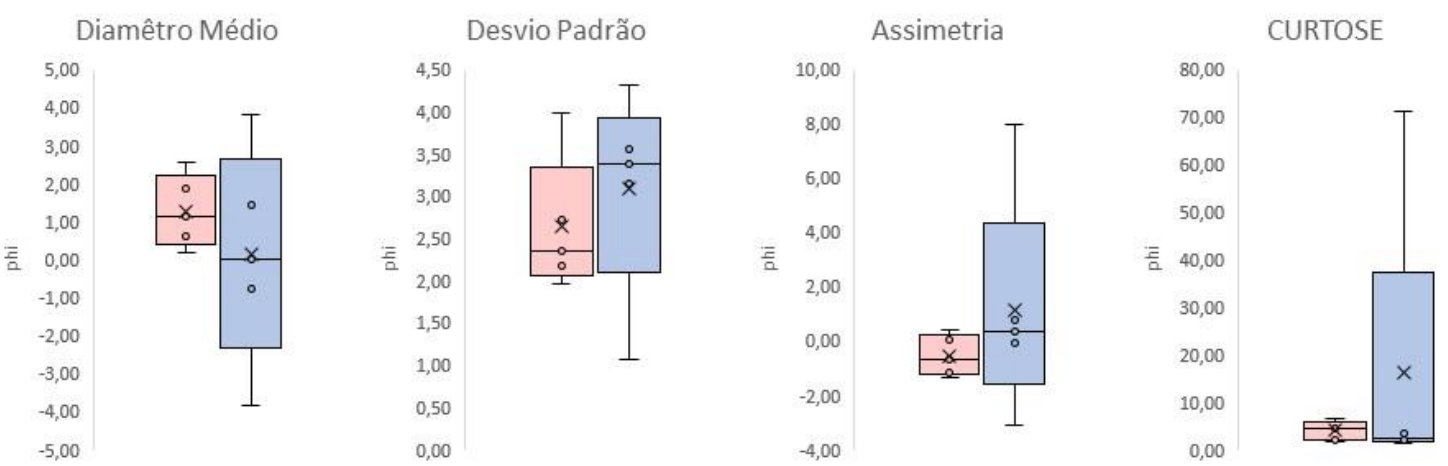

Depósito paleolagunar Sambaqui

Figura 58. Gráficos de caixa (box-plot) comparando as estatísticas da distribuição granulométrica dos quatro primeiros momentos, entre os depósitos paleolagunares e os sambaquis. $\mathrm{N}=43$.

\subsection{Composição taxonômica}

A composição taxonômica observada é principalmente de moluscos, tanto nos sambaquis quanto nos depósitos paleolagunares. Foram identificadas 34 espécies dentro deste filo, sendo 24 provenientes das seções obtidas nos sambaquis ou das trincheiras abertas nos depósitos paleolagunares, e dez representadas por poucos espécimes - comumente por um único indivíduo - oriundas das adjacências das seções ou trincheiras; portanto, pertencentes ao depósito, porém fora do contexto estratigráfico em análise.

De modo geral, a fauna é composta por bivalves e gastrópodes marinhos e de águas salobras, oriundos de lagunas, estuários, costões rochosos e de praia, com distribuição ao longo da costa atlântica das Américas entre a latitudes máximas $42^{\circ} \mathrm{N}$ e $43^{\circ} \mathrm{S}$; mais raramente, ocorrem gastrópodes pulmonados (Megalobulimus sp.), típicos da mata atlântica, conforme detalhados na Tabela 6. Além dos moluscos, foram identificados poucos crustáceos cirrípedes (Ballanus sp.), que habitam substratos rochosos em promontórios de mar aberto ou no interior de baías; e fragmentos diminutos de ossos de peixes. 
Tabela 6. Composição malacológica observada nos sambaquis e depósitos paleolagunares, com informações de habitat e ocorrência compiladas de Souza et al. (2011).

* Táxons recuperados nas adjacências das trincheiras paleolagunares. ** Táxons recuperados nas adjacências das seções sambaquieiras. Escalas:

\begin{tabular}{|c|c|c|}
\hline Táxon & Habitat/ocorrência & Imagem \\
\hline $\begin{array}{l}\text { Anomalocardia } \\
\text { brasiliana } \\
\text { (Gmelin, 1791) }\end{array}$ & $\begin{array}{l}\text { Vive em praias lamosas dentro de baías ou } \\
\text { estuários até } 5 \mathrm{~m} \text { de profundidade. } \\
\text { Distribui-se ao longo da costa atlântica das } \\
\text { Américas entre as latitudes } 18^{\circ} \mathrm{Ne} 39^{\circ} \mathrm{S} \text {. }\end{array}$ & \\
\hline $\begin{array}{l}\text { Brachidontes } \\
\quad \text { exustus } \\
\text { (Linnaeus, 1758) }\end{array}$ & $\begin{array}{l}\text { Vive aderido a substratos duros na região } \\
\text { entremarés e em raízes de mangue. Habita } \\
\text { profundidade de } 0,3 \text { a } 2 \mathrm{~m} \text {. } \\
\text { Distribui-se ao longo da costa atlântica das } \\
\text { Américas entre as latitudes } 35^{\circ} \mathrm{Ne} 35^{\circ} \mathrm{S} \text {. }\end{array}$ & \\
\hline $\begin{array}{l}\text { Bulla occidentalis } \\
\text { (Bruguiere, 1792) }\end{array}$ & $\begin{array}{l}\text { Vive em fundos arenosos, em regiões entremarés. } \\
\text { Distribui-se ao longo da costa atlântica das } \\
\text { Américas entre as latitudes } 35^{\circ} \mathrm{Ne} 38^{\circ} \mathrm{S} \text {. }\end{array}$ & \\
\hline $\begin{array}{l}\text { Cerithium atratum } \\
\quad \text { (Born, 1778) }\end{array}$ & $\begin{array}{l}\text { Vive em substratos arenosos, lodosos e rochosos, } \\
\text { até } 80 \mathrm{~m} \text { de profundidade. } \\
\text { Distribui-se ao longo da costa atlântica das } \\
\text { Américas entre as latitudes } 35^{\circ} \mathrm{Ne} 29^{\circ} \mathrm{S} \text {. }\end{array}$ & \\
\hline $\begin{array}{c}\text { Crassostrea } \\
\text { brasiliana } \\
\text { (Lamarck, 1819) }\end{array}$ & $\begin{array}{l}\text { Vive em substratos duros, rochas e aderida a raízes } \\
\text { de Rhizophora mangle, até } 50 \mathrm{~m} \text {. } \\
\text { Distribui-se ao longo da costa atlântica das } \\
\text { Américas entre as latitudes } 21,4^{\circ} \mathrm{N} \text { e } 35^{\circ} \mathrm{S} \text {. }\end{array}$ & \\
\hline $\begin{array}{l}\text { Chione cancellata } \\
\text { (Linnaeus, 1767) }\end{array}$ & $\begin{array}{l}\text { Vive na região até } 140 \mathrm{~m} \text { de profundidade. Vive em } \\
\text { substratos arenosos, areno-lodosos e em areia } \\
\text { entre rochas. } \\
\text { Distribui-se ao longo da costa atlântica das } \\
\text { Américas entre as latitudes } 35^{\circ} \mathrm{Ne} 28^{\circ} \mathrm{S} \text {. }\end{array}$ & \\
\hline $\begin{array}{l}\text { Crepidula pyguaia } \\
\text { (Simone, 2006) }\end{array}$ & $\begin{array}{l}\text { Vive em substratos rochosos, sobre corais e } \\
\text { mangue, de } 12 \text { a } 36 \mathrm{~m} \text { de profundidade. } \\
\text { Distribui-se ao longo da costa atlântica das } \\
\text { Américas entre as latitudes } 35^{\circ} \mathrm{Ne} 42^{\circ} \mathrm{S} \text {. }\end{array}$ & \\
\hline $\begin{array}{l}\text { Cymatium } \\
\text { parthenopeum } \\
\text { (von Salis, 1793) }\end{array}$ & $\begin{array}{l}\text { Vive em substratos rochosos, até } 65 \mathrm{~m} \text { de } \\
\text { profundidade. } \\
\text { Distribui-se ao longo da costa atlântica das } \\
\text { Américas entre as latitudes } 35^{\circ} \mathrm{Ne} 35^{\circ} \mathrm{S} \text {. }\end{array}$ & \\
\hline $\begin{array}{c}\text { Cyrtopleura } \\
\text { costata* }^{*} \\
\text { (Linnaeus, } 1758)\end{array}$ & $\begin{array}{l}\text { Perfurante de substratos lodosos e rochas de baixa } \\
\text { resistência, até } 10 \mathrm{~m} \text { de profundidade. } \\
\text { Distribui-se ao longo da costa atlântica das } \\
\text { Américas entre as latitudes } 42^{\circ} \mathrm{Ne} 28^{\circ} \mathrm{S} \text {. }\end{array}$ & \\
\hline
\end{tabular}




\begin{tabular}{|c|c|c|}
\hline Táxon & Habitat/ocorrência & Imagem \\
\hline $\begin{array}{l}\text { Dosinia } \\
\text { concêntrica } \\
\text { (Born, 1778) }\end{array}$ & $\begin{array}{l}\text { Vive em fundos arenosos desde a baixa-mar até } 60 \\
\mathrm{~m} \text { de profundidade. } \\
\text { Distribui-se ao longo da costa atlântica das } \\
\text { Américas entre as latitudes } 22^{\circ} \mathrm{Ne} 28^{\circ} \mathrm{S} \text {. }\end{array}$ & \\
\hline $\begin{array}{c}\text { Dallocardia } \\
\text { muricata } \\
\text { (Linnaeus, 1758) }\end{array}$ & $\begin{array}{l}\text { Vive em fundos arenosos entre rochas ou em } \\
\text { sedimento areno-lodoso. } \\
\text { Distribui-se ao longo da costa atlântica das } \\
\text { Américas entre as latitudes } 35^{\circ} \mathrm{N} \text { e } 42^{\circ} \mathrm{S} \text {. }\end{array}$ & \\
\hline $\begin{array}{c}\text { Divalinga } \\
\text { quadrisulcata } \\
\text { (d'Orbigny, 1845) }\end{array}$ & $\begin{array}{l}\text { Vive em substratos arenosos, até } 100 \mathrm{~m} \text { de } \\
\text { profundidade. } \\
\text { Distribui-se ao longo da costa atlântica das } \\
\text { Américas entre as latitudes } 42^{\circ} \mathrm{N} \text { e } 29^{\circ} \mathrm{S} \text {. }\end{array}$ & \\
\hline $\begin{array}{l}\text { Donax } \\
\text { hanleyanus** } \\
\text { (Philippi, 1842) }\end{array}$ & $\begin{array}{l}\text { Vive na região entremarés de praias arenosas. } \\
\text { Distribui-se ao longo da costa atlântica das } \\
\text { Américas entre as latitudes } 21^{\circ} \mathrm{N} \text { e } 38^{\circ} \mathrm{S} \text {. }\end{array}$ & \\
\hline $\begin{array}{l}\text { Eurytellina lineata } \\
\text { (W. Turton, 1819) }\end{array}$ & $\begin{array}{l}\text { Vive em fundos arenosos, até } 10 \mathrm{~m} \text { de } \\
\text { profundidade. } \\
\text { Distribui-se ao longo da costa atlântica das } \\
\text { Américas entre as latitudes } 35^{\circ} \mathrm{N} \text { e } 35^{\circ} \mathrm{S} \text {. }\end{array}$ & \\
\hline $\begin{array}{l}\text { Erodona } \\
\text { mactroides } \\
\text { (Bosc, 1802) }\end{array}$ & $\begin{array}{l}\text { Vive em fundos lodosos, até } 10 \mathrm{~m} \text { de profundidade. } \\
\text { Distribui-se ao longo da costa atlântica das } \\
\text { Américas entre as latitudes } 26^{\circ} \mathrm{N} \text { e } 35^{\circ} \mathrm{S} \text {. }\end{array}$ & \\
\hline $\begin{array}{c}\text { Iphigenia } \\
\text { brasiliana } \\
\text { (Lamarck, 1818) }\end{array}$ & $\begin{array}{l}\text { Vive na região entremarés de praias arenosas, } \\
\text { areno-lamosas e em estuários, e enterra-se a cerca } \\
\text { de } 20 \mathrm{~cm} \text { de profundidade. } \\
\text { Distribui-se ao longo da costa atlântica das } \\
\text { Américas entre as latitudes } 26^{\circ} \mathrm{N} \text { e } 35^{\circ} \mathrm{S} \text {. }\end{array}$ & \\
\hline $\begin{array}{l}\text { Lirophora paphia } \\
\text { (Linnaeus, 1767) }\end{array}$ & $\begin{array}{l}\text { Vive em substratos arenosos, de } 10 \text { a } 100 \mathrm{~m} \text { de } \\
\text { profundidade. } \\
\text { Distribui-se ao longo da costa atlântica das } \\
\text { Américas entre as latitudes } 20^{\circ} \mathrm{N} \text { e } 35^{\circ} \mathrm{S} \text {. }\end{array}$ & \\
\hline $\begin{array}{l}\text { Lunarca ovalis** } \\
\text { (Bruguière, 1789) }\end{array}$ & $\begin{array}{l}\text { Praia e infralitoral, até } 35 \mathrm{~m} \text { de profundidade, em } \\
\text { sedimento arenoso, em rochas e em corais. } \\
\text { Distribui-se ao longo da costa atlântica das } \\
\text { Américas entre as latitudes } 35^{\circ} \mathrm{N} \text { e } 35^{\circ} \mathrm{S} \text {. }\end{array}$ & \\
\hline
\end{tabular}




\begin{tabular}{|c|c|c|}
\hline Táxon & Habitat/ocorrência & Imagem \\
\hline $\begin{array}{c}\text { Macoma constricta } \\
\text { (Bruguière, 1792) }\end{array}$ & $\begin{array}{l}\text { Vive na região entremarés de praias areno-lamosas } \\
\text { e em ambientes estuarinos. Enterra-se até cerca de } \\
30 \mathrm{~cm} \text { de profundidade em posição horizontal } \\
\text { apoiada sobre a valva esquerda. } \\
\text { Distribui-se ao longo da costa atlântica das } \\
\text { Américas entre as latitudes } 35^{\circ} \mathrm{Ne} 28^{\circ} \mathrm{S} \text {. }\end{array}$ & \\
\hline $\begin{array}{c}\text { Mactrotoma } \\
\text { fragilis }^{\star *} \\
\text { (Gmelin, 1791) }\end{array}$ & $\begin{array}{l}\text { Vive em fundos arenosos, até } 100 \mathrm{~m} \text { de } \\
\text { profundidade. } \\
\text { Distribui-se ao longo da costa atlântica das } \\
\text { Américas entre as latitudes } 35^{\circ} \mathrm{N} \text { e } 28^{\circ} \mathrm{S} \text {. }\end{array}$ & \\
\hline $\begin{array}{c}\text { Macrocallista } \\
\text { maculata** } \\
\text { (Linnaeus, 1758) }\end{array}$ & $\begin{array}{l}\text { Vive em fundos arenosos, até } 100 \mathrm{~m} \text { de } \\
\text { profundidade. } \\
\text { Distribui-se ao longo da costa atlântica das } \\
\text { Américas entre as latitudes } 19^{\circ} \mathrm{N} \text { e } 43^{\circ} \mathrm{S} \text {. }\end{array}$ & \\
\hline $\begin{array}{c}\text { Mytella } \\
\text { guyanensis } \\
\text { (Lamarck, 1819) }\end{array}$ & $\begin{array}{l}\text { Vive em fundos areno-lodosos, aderidos a rochas. } \\
\text { Distribui-se ao longo da costa atlântica das } \\
\text { Américas entre as latitudes } 11^{\circ} \mathrm{Ne} 32^{\circ} \mathrm{S} \text {. }\end{array}$ & \\
\hline $\begin{array}{l}\text { Megalobulimus } \\
\text { paranaguensis } \\
\text { (Pilsby \& Ihering, } \\
1900 \text { ) }\end{array}$ & $\begin{array}{l}\text { Vive na mata atlântica, entre o norte do estado de } \\
\text { Santa Catarina e São Vicente, no Estado de São } \\
\text { Paulo. }\end{array}$ & \\
\hline$\underset{* *}{\text { Megalobulimus sp. }}$ & $\begin{array}{l}\text { Vive na mata atlântica, entre o norte do estado de } \\
\text { Santa Catarina e São Vicente, no Estado de São } \\
\text { Paulo. }\end{array}$ & \\
\hline $\begin{array}{c}\text { Nassarius vibex } \\
\text { (Say, 1822) }\end{array}$ & $\begin{array}{l}\text { Vive em substratos lodosos e arenosos, em águas } \\
\text { salobras. Distribui-se ao longo da costa atlântica } \\
\text { das Américas entre as latitudes } 35^{\circ} \mathrm{N} \text { e } 28^{\circ} \mathrm{S} \text {. }\end{array}$ & \\
\hline $\begin{array}{l}\text { Neritina virgínea } \\
\text { (Linnaeus, 1758) }\end{array}$ & $\begin{array}{l}\text { Vive em fundos lamosos de águas salobras, sobre } \\
\text { raízes de mangue e conchas de moluscos mortos. } \\
\text { Pode viver em praias rochosas mais abrigadas. } \\
\text { Distribui-se ao longo da costa atlântica das } \\
\text { Américas entre as latitudes } 35^{\circ} \mathrm{N} \text { e } 28^{\circ} \mathrm{S} \text {. }\end{array}$ & \\
\hline $\begin{array}{l}\text { Olivancillaria } \\
\text { contortuplicata** }^{*} \\
\text { (Reeve, 1850) }\end{array}$ & $\begin{array}{l}\text { Vive em substratos arenosos, em águas rasas. } \\
\text { Distribui-se ao longo da costa atlântica das } \\
\text { Américas entre as latitudes } 28^{\circ} \mathrm{N} \text { e } 35^{\circ} \mathrm{S} \text {. }\end{array}$ & \\
\hline $\begin{array}{l}\text { Olivancillaria } \\
\text { urceus** } \\
\text { (Röding, 1798) }\end{array}$ & $\begin{array}{l}\text { Vive em fundos arenosos, até } 30 \mathrm{~m} \text { de } \\
\text { profundidade. Distribui-se ao longo da costa } \\
\text { atlântica das Américas entre as latitudes } 19^{\circ} \mathrm{Ne} 42^{\circ} \\
\text { S. }\end{array}$ & \\
\hline
\end{tabular}




\begin{tabular}{|c|c|c|}
\hline Táxon & Habitat/ocorrência & Imagem \\
\hline $\begin{array}{l}\text { Olivancillaria } \\
\text { vesica** } \\
\text { (Gmelin, 1791) }\end{array}$ & $\begin{array}{l}\text { Vive em substratos arenosos, em águas rasas. } \\
\text { Distribui-se ao longo da costa brasileira, do Estado } \\
\text { do Rio de Janeiro até Santa Catarina, entre as } \\
\text { latitudes } 21,3^{\circ} \mathrm{N} \text { e } 28^{\circ} \mathrm{S} \text {. }\end{array}$ & \\
\hline $\begin{array}{l}\text { Pinctada imbricata } \\
\text { (Röding, 1798) }\end{array}$ & $\begin{array}{l}\text { Vive em águas rasas, aderida a rochas, corais, } \\
\text { raízes de mangue e, algumas vezes, associada à } \\
\text { esponjas. Distribui-se ao longo da costa atlântica } \\
\text { das Américas entre as latitudes } 33^{\circ} \mathrm{N} \text { e } 28^{\circ} \mathrm{S} \text {. No } \\
\text { Brasil, está presente do Estado do Pará até Santa } \\
\text { Catarina. }\end{array}$ & \\
\hline $\begin{array}{c}\text { Phacoides } \\
\text { pectinatus } \\
\text { (Gmelin, 1791) }\end{array}$ & $\begin{array}{l}\text { Vive em substratos arenosos e areno-lodosos. } \\
\text { Distribui-se ao longo da costa atlântica das } \\
\text { Américas entre as latitudes } 35^{\circ} \mathrm{N} \text { e } 28^{\circ} \mathrm{S} \text {. Na costa } \\
\text { brasileira, está presente do Amapá a Santa } \\
\text { Catarina. }\end{array}$ & \\
\hline $\begin{array}{l}\text { Petaloconchus } \\
\quad \text { varians } \\
\text { (d'Orbigny, 1839) }\end{array}$ & Vive fixo sobre substrato rochoso, corais e conchas. & \\
\hline $\begin{array}{l}\text { Stramonita } \\
\text { brasiliensis } \\
\text { (Claremont \& D.G. } \\
\text { Reid, 2011) }\end{array}$ & $\begin{array}{l}\text { Vive em substratos rochosos, em regiões } \\
\text { entremarés. Distribui-se ao longo da costa atlântica } \\
\text { das Américas entre as latitudes } 35^{\circ} \mathrm{N} \text { e } 35^{\circ} \mathrm{S} \text {. }\end{array}$ & \\
\hline $\begin{array}{l}\text { Tagelus plebeius } \\
\text { (Lightfoot, 1786) }\end{array}$ & $\begin{array}{l}\text { Vive em fundos arenosos, areno-lodosos e em } \\
\text { desembocaduras de rios, até } 10 \mathrm{~m} \text { de profundidade. } \\
\text { Distribui-se ao longo da costa atlântica das } \\
\text { Américas entre as latitudes } 35^{\circ} \mathrm{N} \text { e } 48^{\circ} \mathrm{S} \text {. }\end{array}$ & \\
\hline
\end{tabular}

Das 4121 conchas analisadas, incluindo fragmentos, $80 \%$ pertencem ao berbigão $A$. brasiliana e $13 \%$ à ostra $C$. brasiliana. Dentre os depósitos paleolagunares, o único que apresentou registro expressivo de ostras foi o $\mathrm{CPL}$ (Figura 59), próximo ao sambaqui Caipora, um dos dois constituídos de fácies dominadas por ostras; o outro é o Jaboticabeira 1 (Figura 60). 


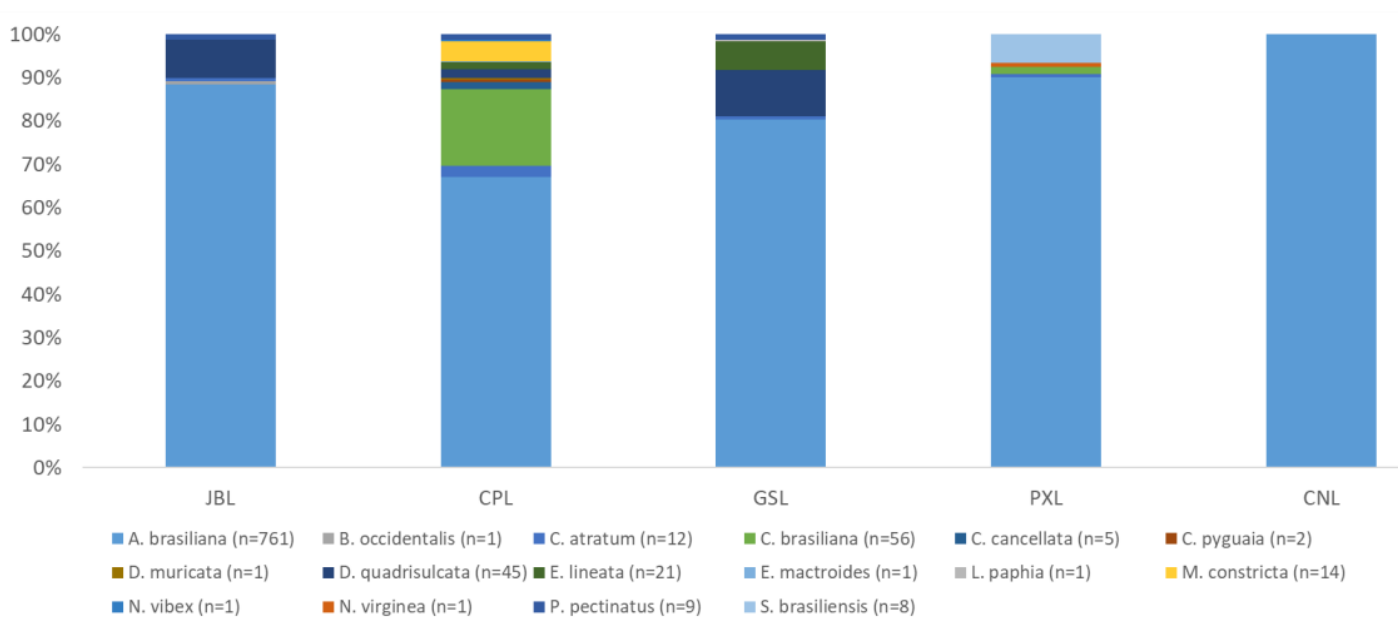

Figura 59. Composição taxonômica dos depósitos paleolagunares analisados com domínio de $A$. brasiliana em todos os casos; apenas o depósito CPL possui registro expressivo de $C$. brasiliana em relação aos demais.

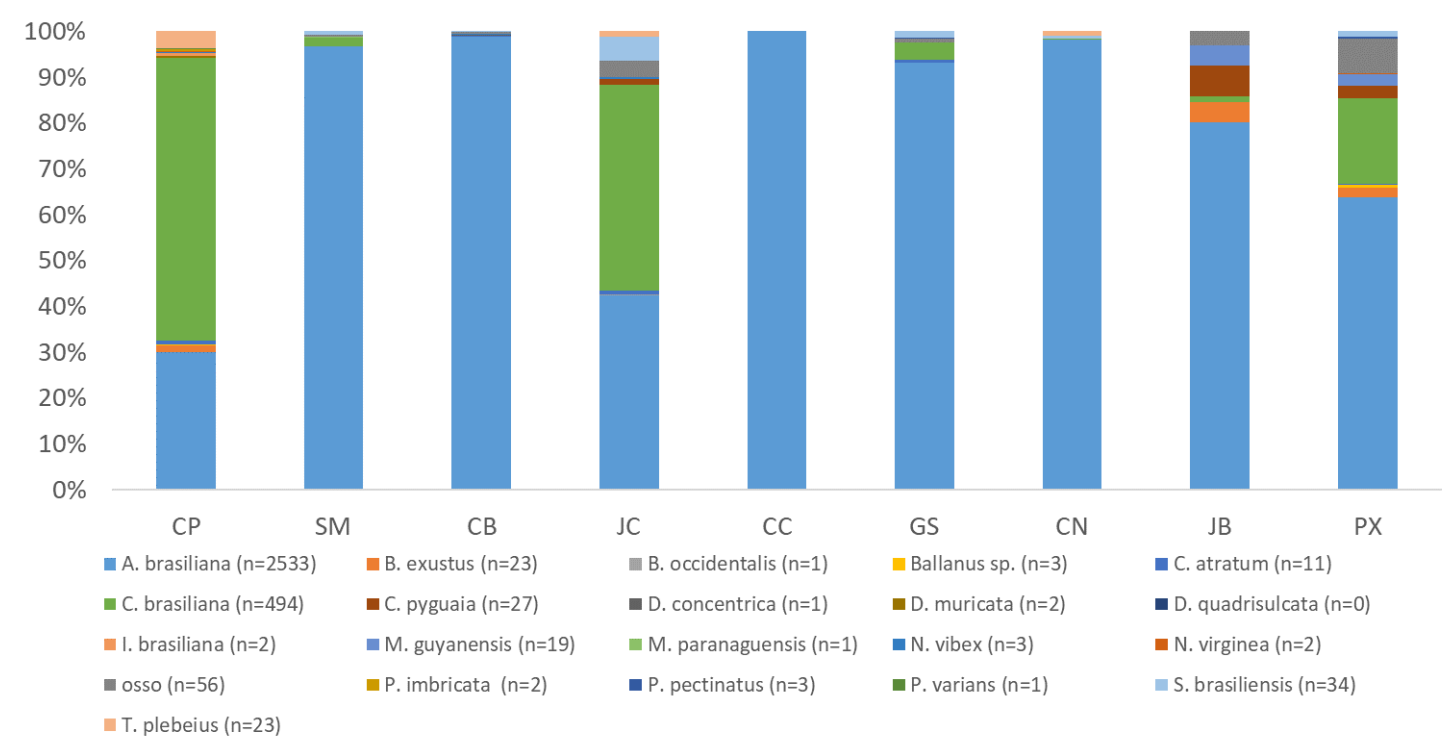

Figura 60. Composição taxonômica dos sambaquis analisados com domínio de A. brasiliana na maioria dos casos, exceto pelos sambaquis Caipora e Jaboticabeira 1, onde dominam conchas de C. brasiliana.

A composição malacológica, em ambos os tipos de depósitos, natural e arqueológico, é complementada pela presença de B. occidentalis, C. atratum, C. pyguaia, D. muricata, E. mactroides, V. vibex, V. virginea, $P$. pectinatus e $S$. brasiliensis (Figuras 61 e 62). Ainda ocorrem, de modo exclusivo, nos depósitos paleolagunares, os táxons $C$. cancellata, D. quadrisulcata, E. lineata, L. paphia e M. constricta (Figura 61); e nos sambaquis, B. exustus, D. concentrica, I. brasiliana, $M$. guyanensis, M. paranaguensis, P. imbricata, $P$. varians e T. plebeius (Figura 62). 


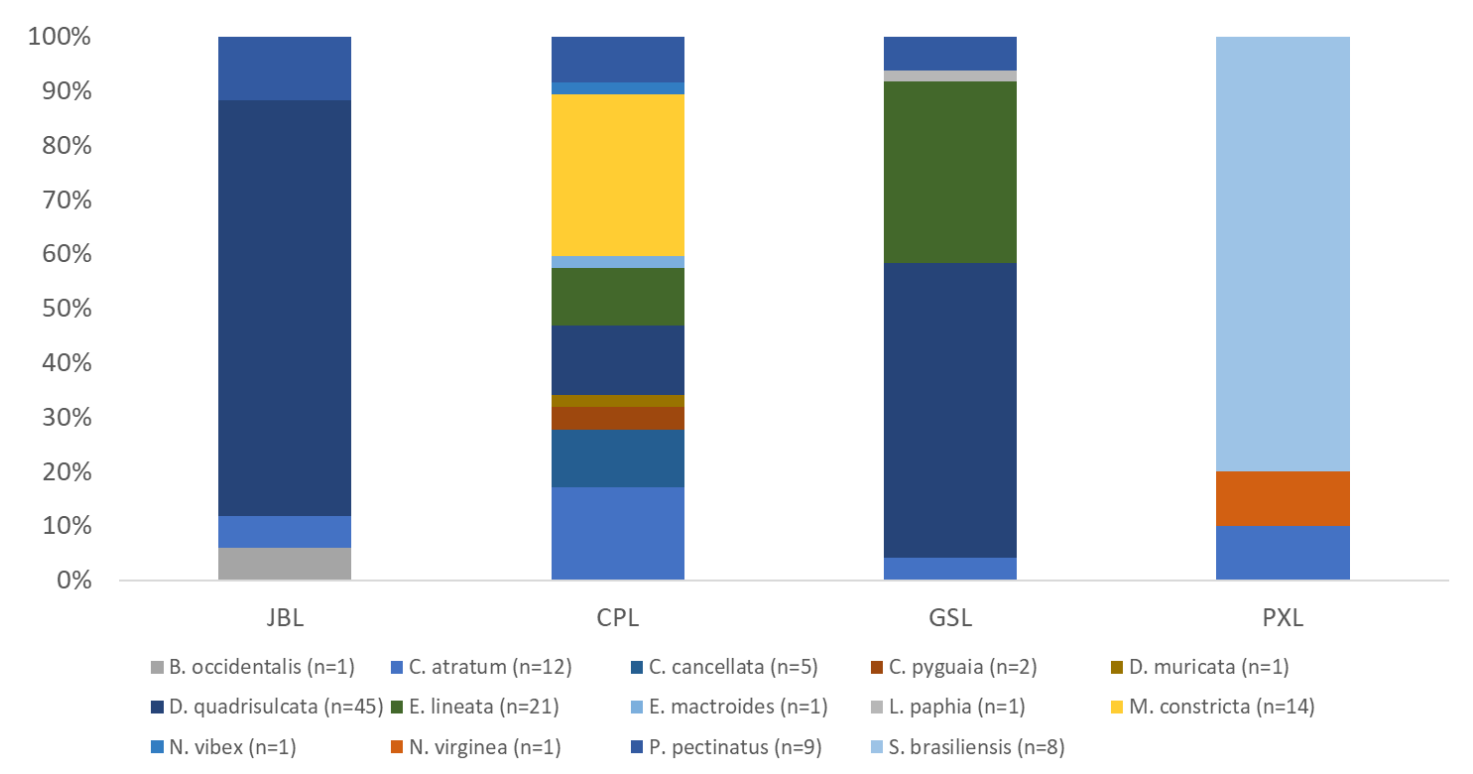

Figura 61. Composição taxonômica dos depósitos paleolagunares analisados, excetuando-se $A$. brasiliana e C. brasiliana.

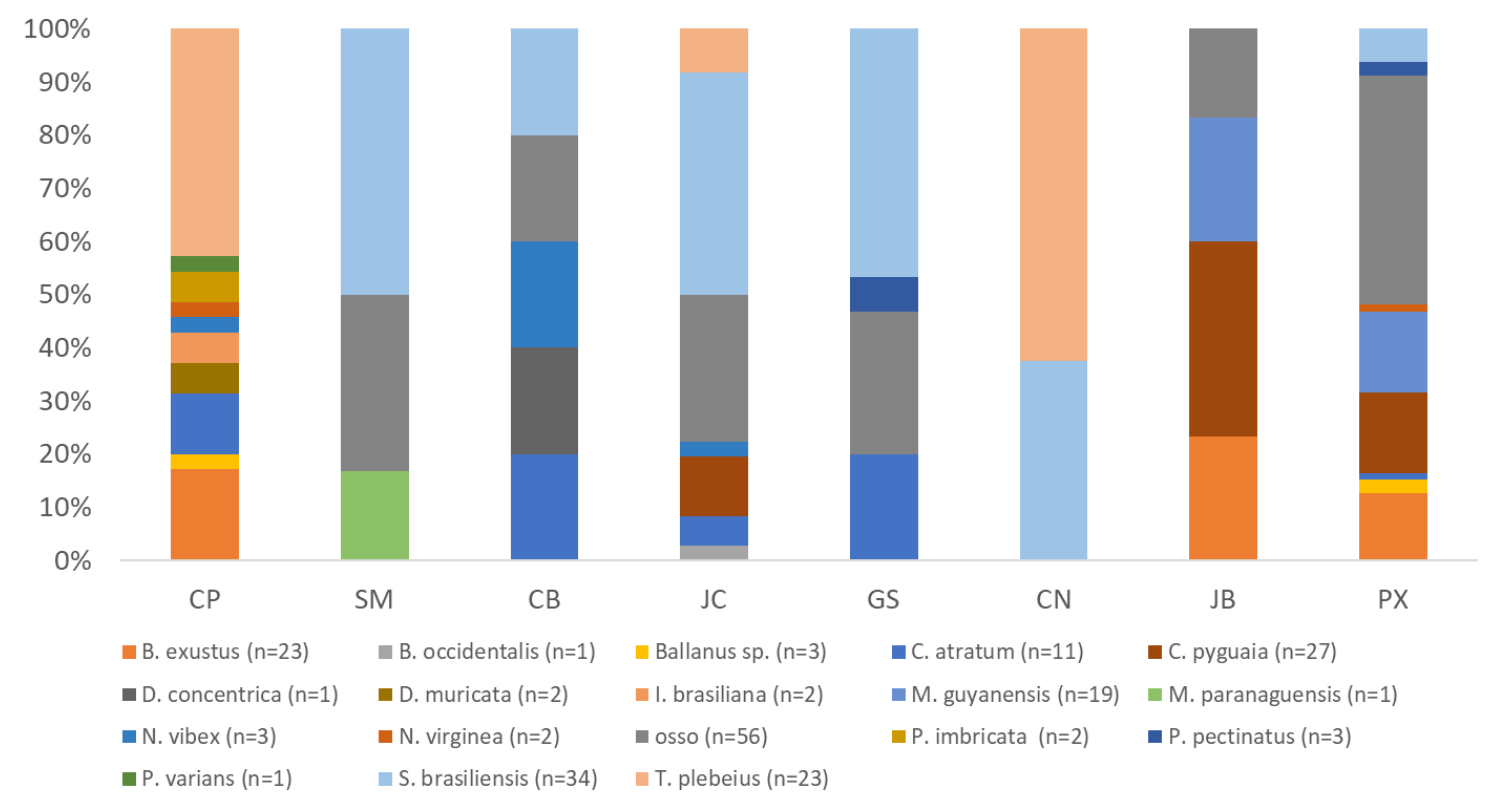

Figura 62. Composição taxonômica dos sambaquis analisados, excetuando-se $A$. brasiliana e $C$. brasiliana. 


\subsection{Tafonomia}

5.5.1 Caracterização tafonômica dos depósitos

Nos depósitos paleolagunares, as três camadas que exibiram maior proporção (acima de 65\%) de conchas inteiras ou pouco fragmentadas (graus 0 ou 1) foram CPL2-C1 (fácies LaCpv), GSL-C1 (ACpv) e PXL-C1 (CiALmo) (Figura 63). As outras quatro camadas paleolagunares correspondem a fácies em que já se havia destacado, em campo, a presença de conchas quebradas (CiqA, Ciqg, e CqA).

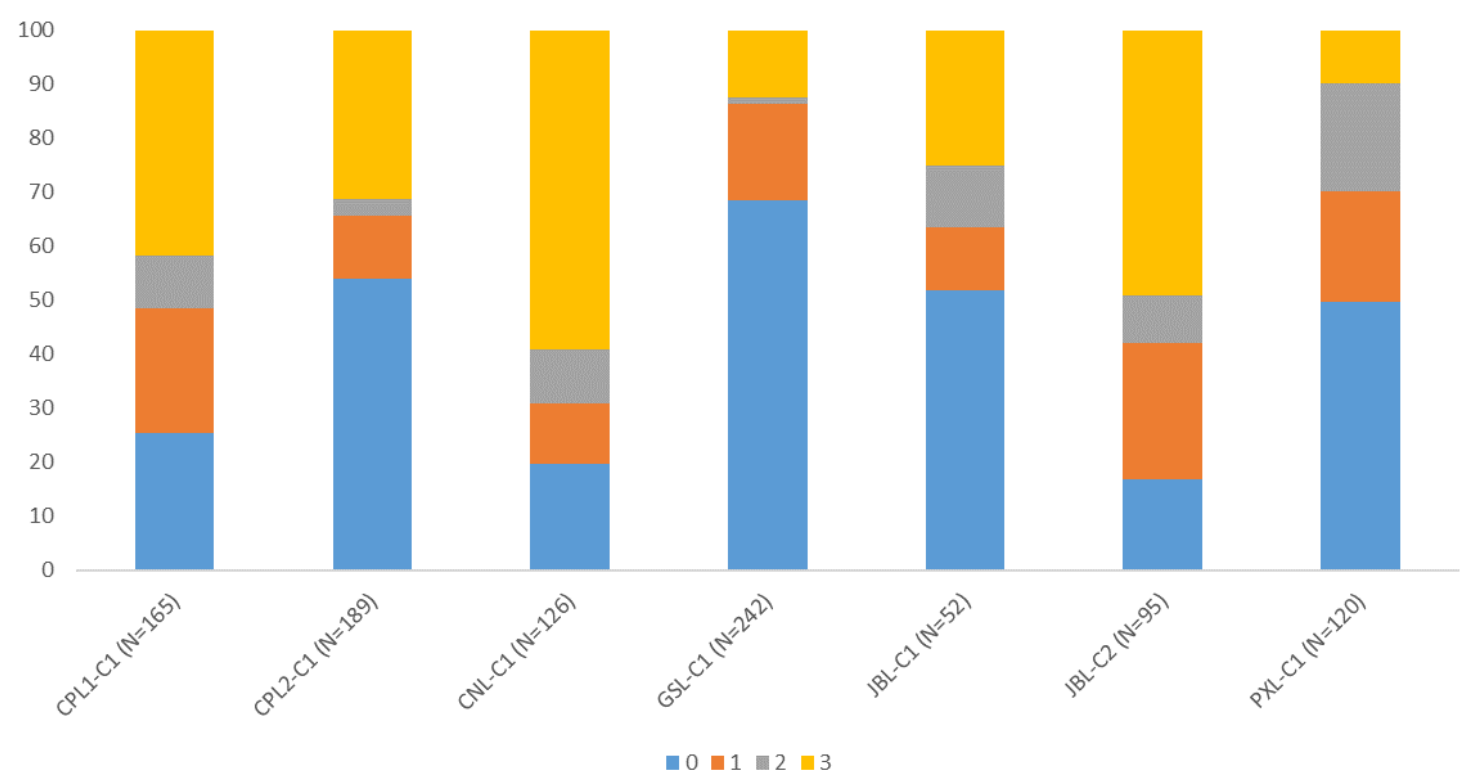

Figura 63. Graus de fragmentação entre os depósitos paleolagunares.

Quanto à dissolução, as camadas dos depósitos paleolagunares CPL1-C1 (CiqA), CNL-C1 (Ciqg) e JBL-C2 (CqA), correspondentes àquelas com maior frequência de conchas fragmentadas em grau máximo (3), apresentaram grau máximo também de dissolução (Figura 64). 


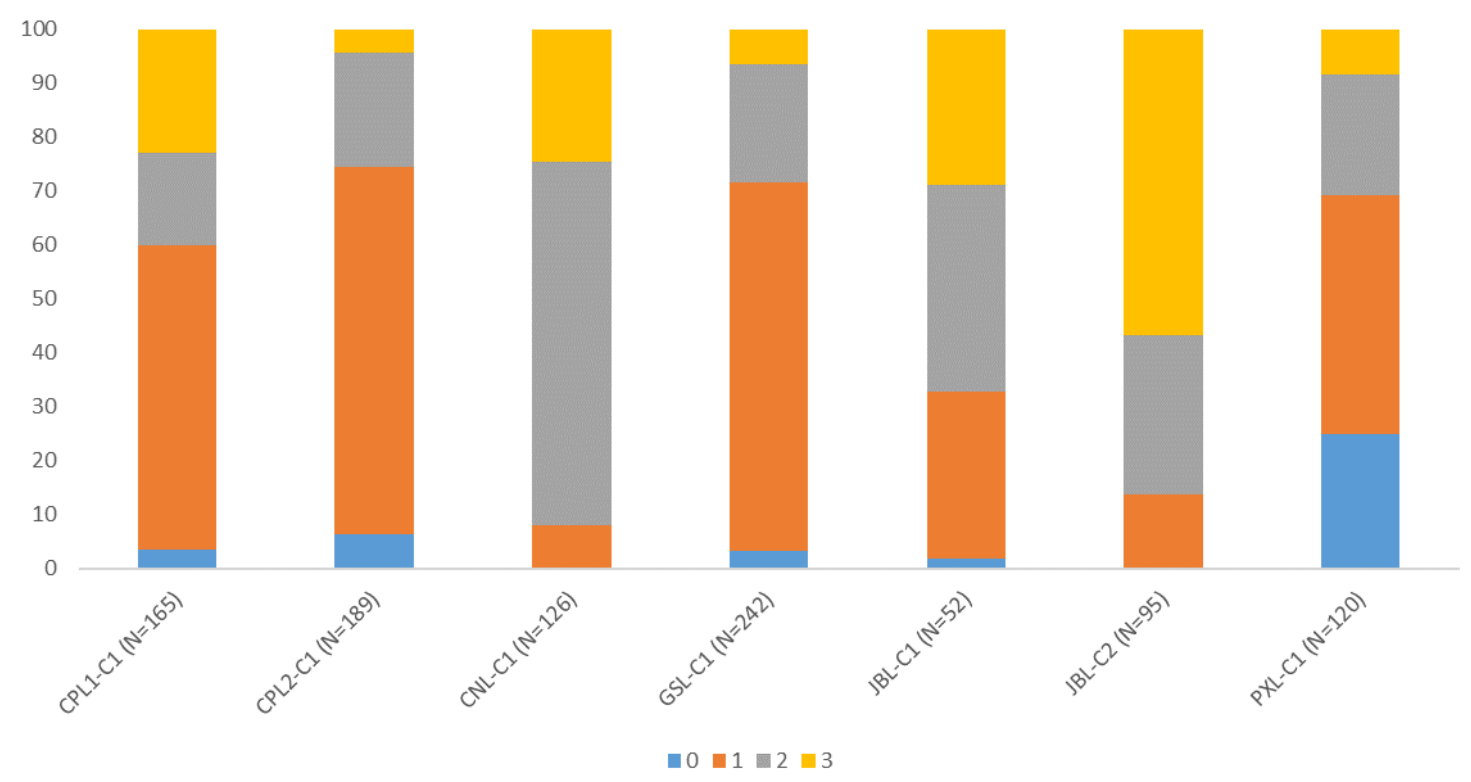

Figura 64. Graus de dissolução entre os depósitos paleolagunares.

Oxidação parece ocorrer, preferencialmente, na camada 1 dos depósitos CPL2 e PXL (Figura 65), o primeiro exibindo, também, elevada proporção de conchas com grau máximo dessa assinatura tafonômica (3) e eventual presença de precipitação (Figura 66).

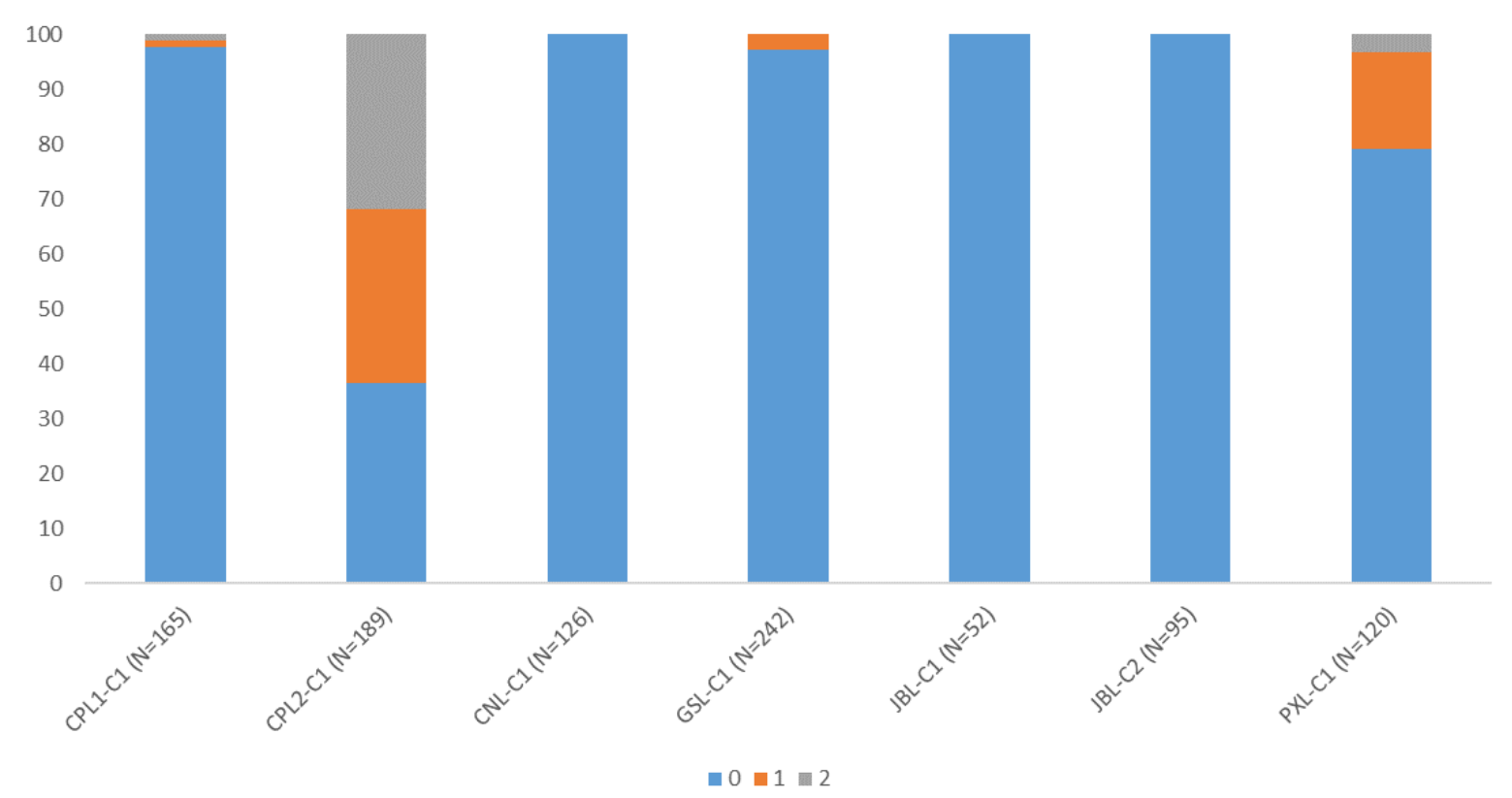

Figura 65. Graus de oxidação entre os depósitos paleolagunares. 


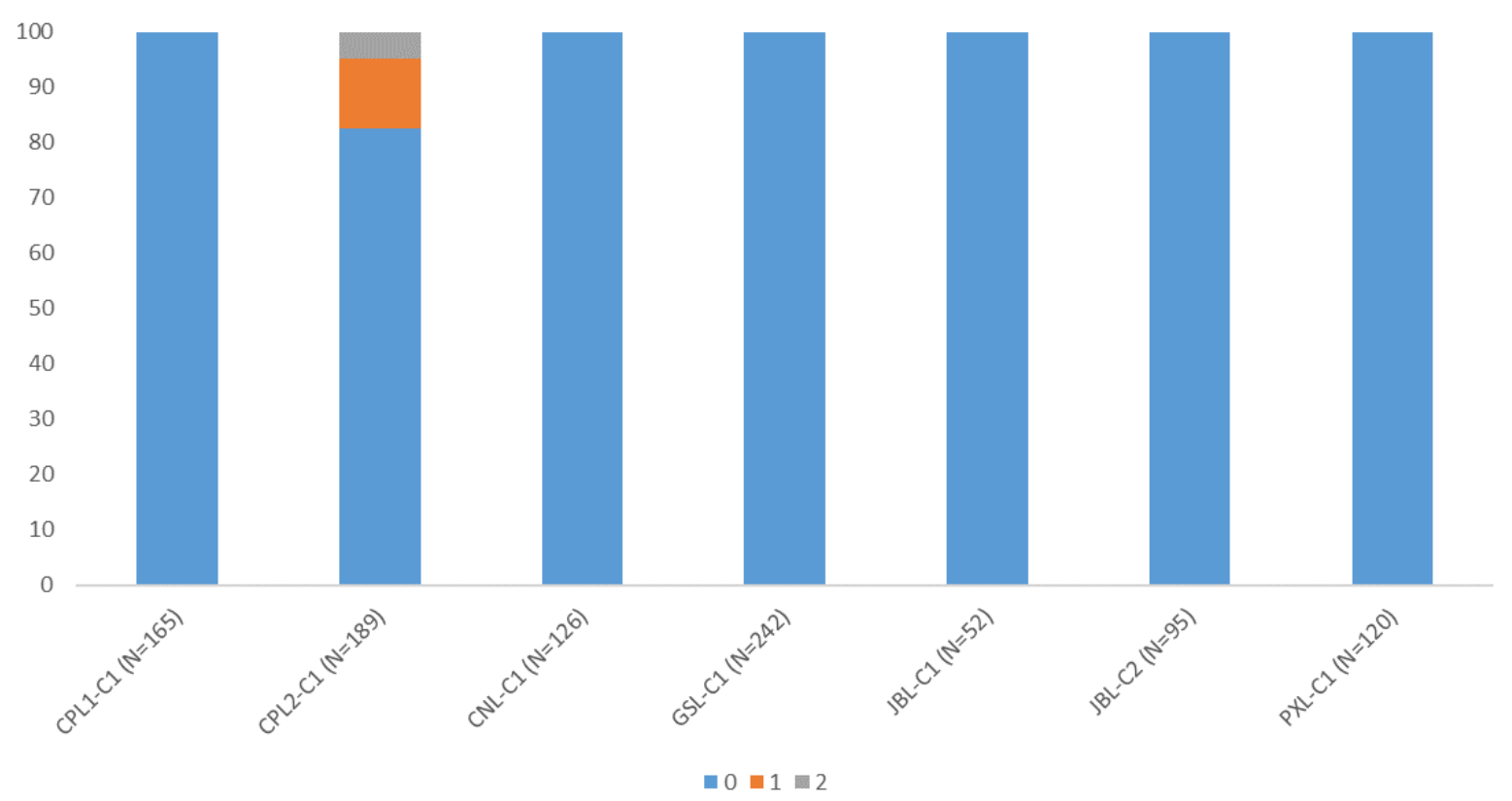

Figura 66. Graus de precipitação entre os depósitos paleolagunares.

Nos sambaquis, camadas contendo conchas preferencialmente íntegras (grau 0 de fragmentação), ocorrem nos sítios Cabeçuda, Carniça 1 e 3, Garopaba do Sul, Perrixil e Santa Marta 2, ao passo que camadas contendo mais de $50 \%$ de conchas com grau máximo de fragmentação se encontram no Caipora (CP), em toda sua extensão vertical, no topo do Garopaba do Sul (camada 6), no Jaboticabeira 1 (JC) e na camada 3 do Perrixil (PX1) (Figura 67).

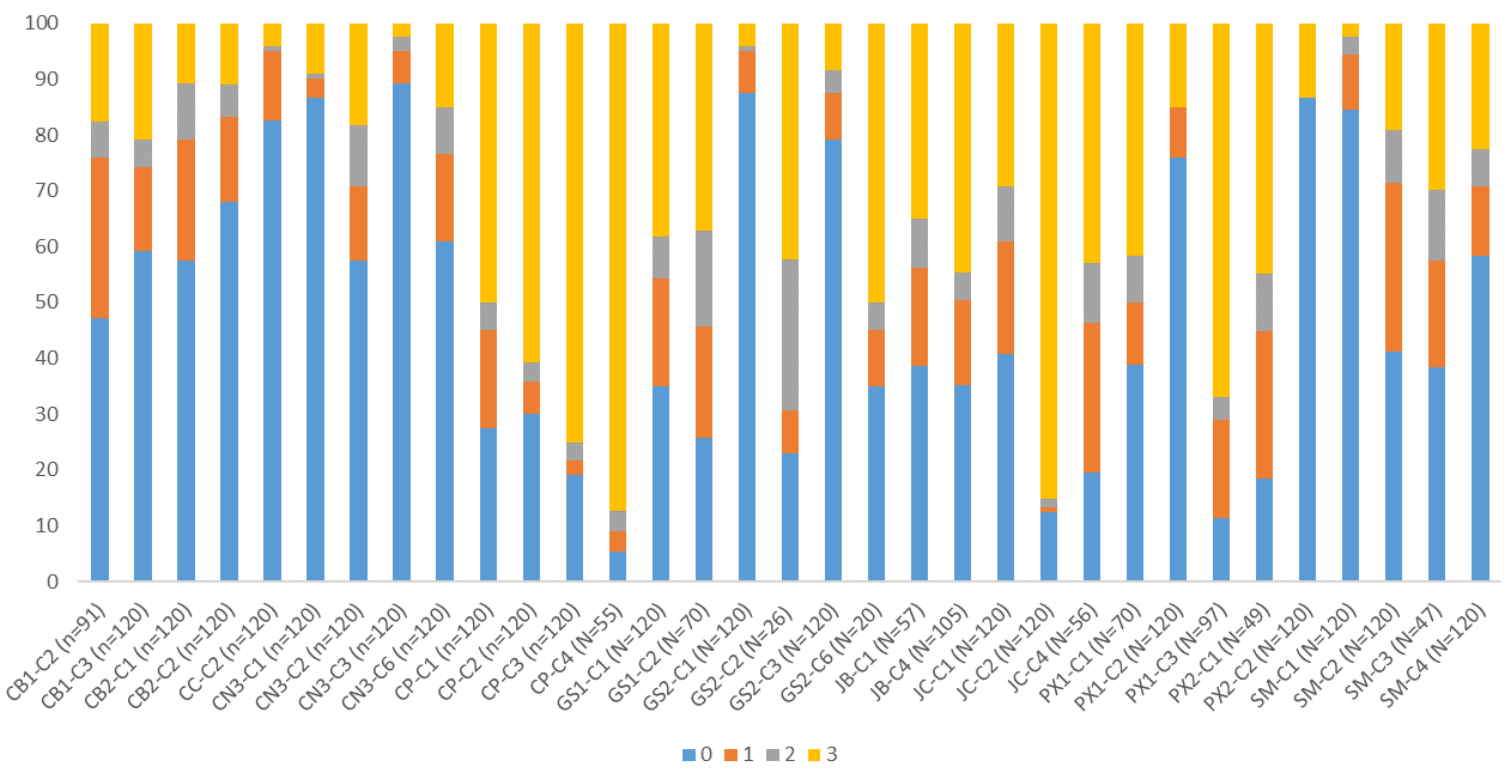

Figura 67. Graus de fragmentação entre os sambaquis. 
Conchas sem sinais de dissolução (grau 0), nos sambaquis, ocorrem nos sítios Carniça 1 e 3, e nas camadas estratigraficamente inferiores do Jaboticabeira 2, Perrixil (PX2) e Santa Marta 2. Os demais sambaquis possuem conchas com algum grau de dissolução (variando de 1 a 2) e, as camadas que apresentam majoritariamente conchas com grau máximo (3) são a C2 do Cabeçuda, em ambas seções (CB1 e CB2), e C1 do Garopaba do Sul (GS2) (Figura 68).

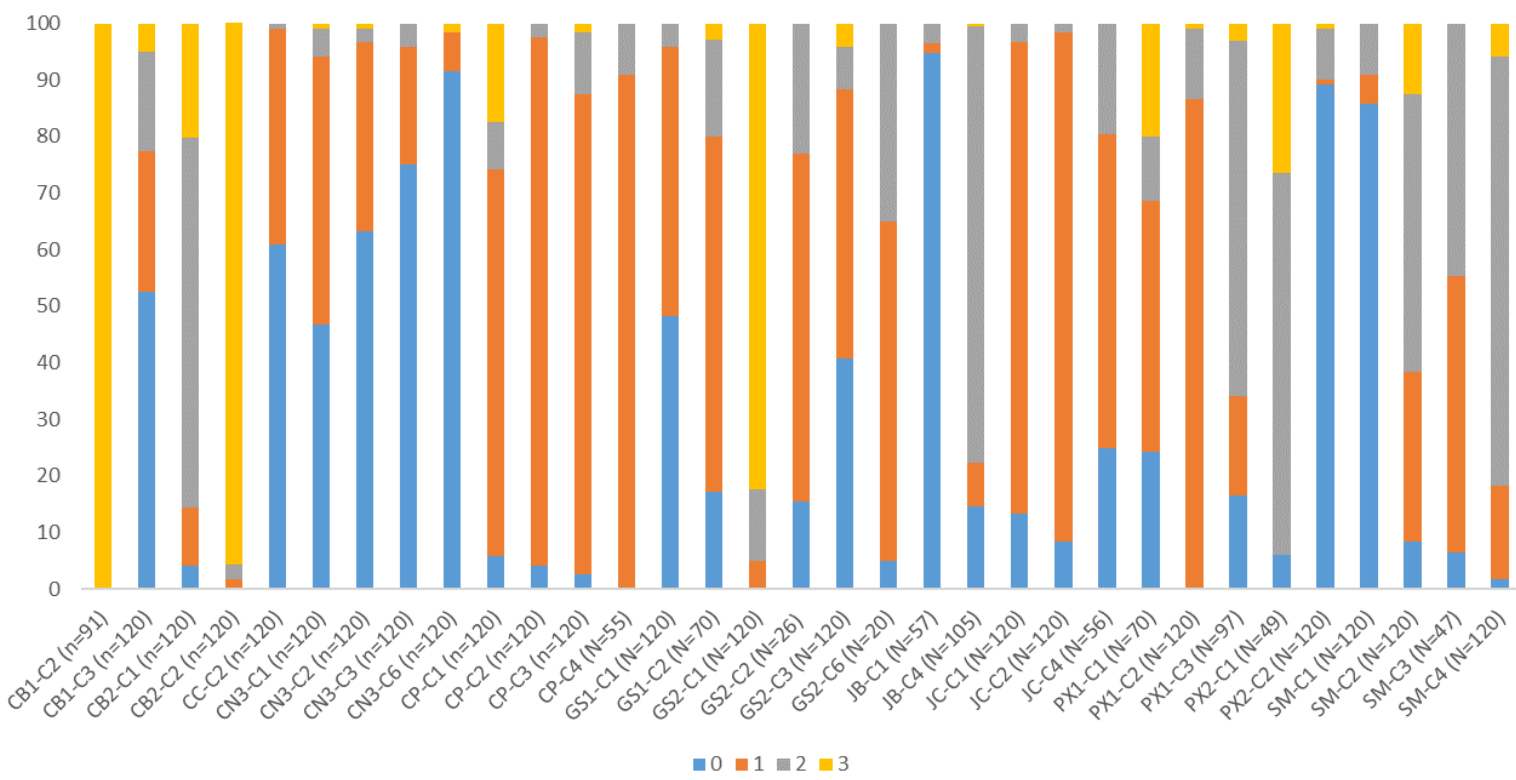

Figura 68. Graus de dissolução entre os sambaquis.

Camadas que contêm alta proporção de conchas com graus máximos (2) de oxidação ou de precipitação ocorrem nos sambaquis Cabeçuda (CB1), Garopaba do Sul e Santa Marta 2 (Figuras 69 e 70), com destaque para CB1-C2, GS1-C2 e SM$\mathrm{C} 3$, em que ambas as assinaturas apresentam simultaneamente registro expressivo de graus máximos. 


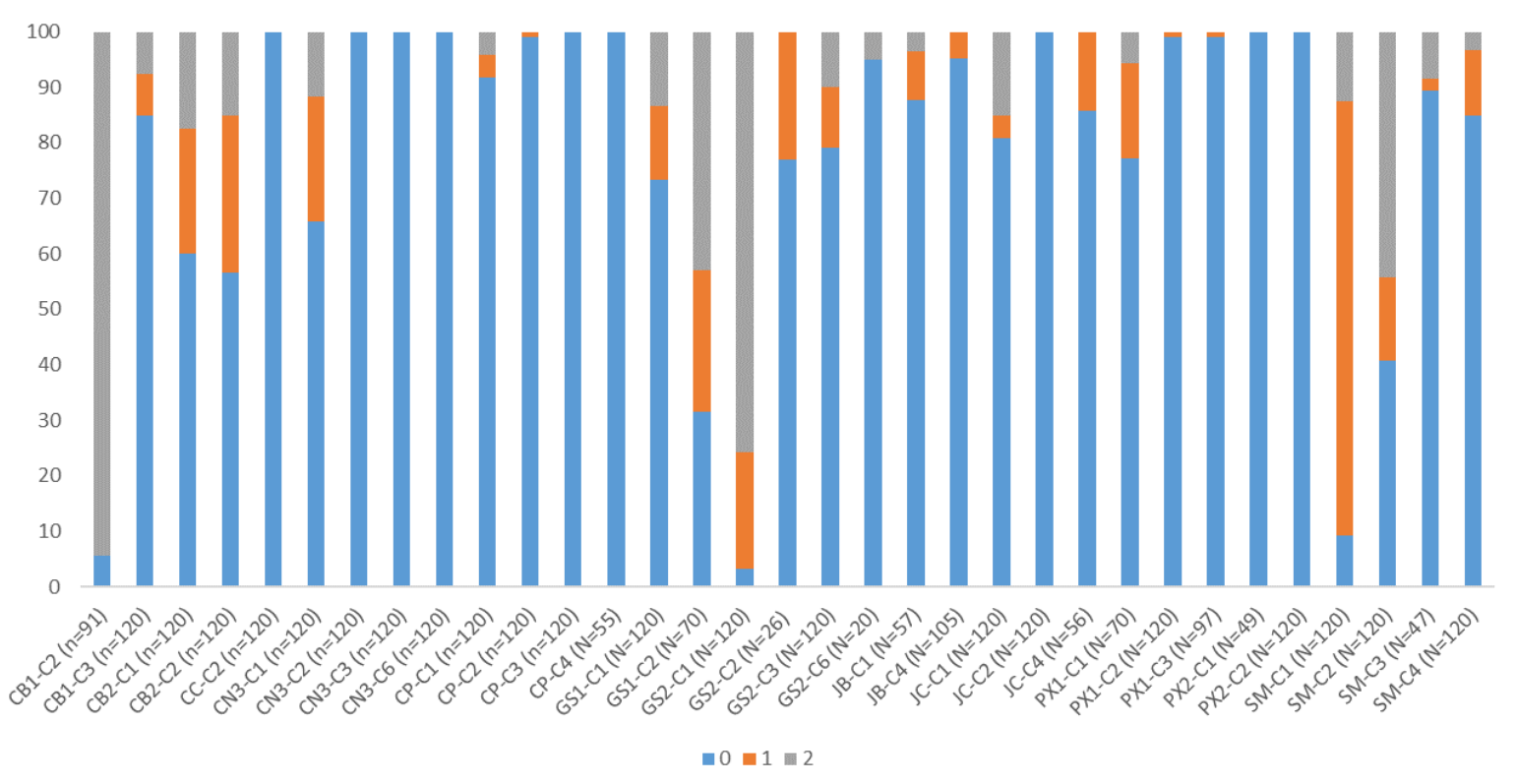

Figura 69. Graus de oxidação entre os sambaquis.

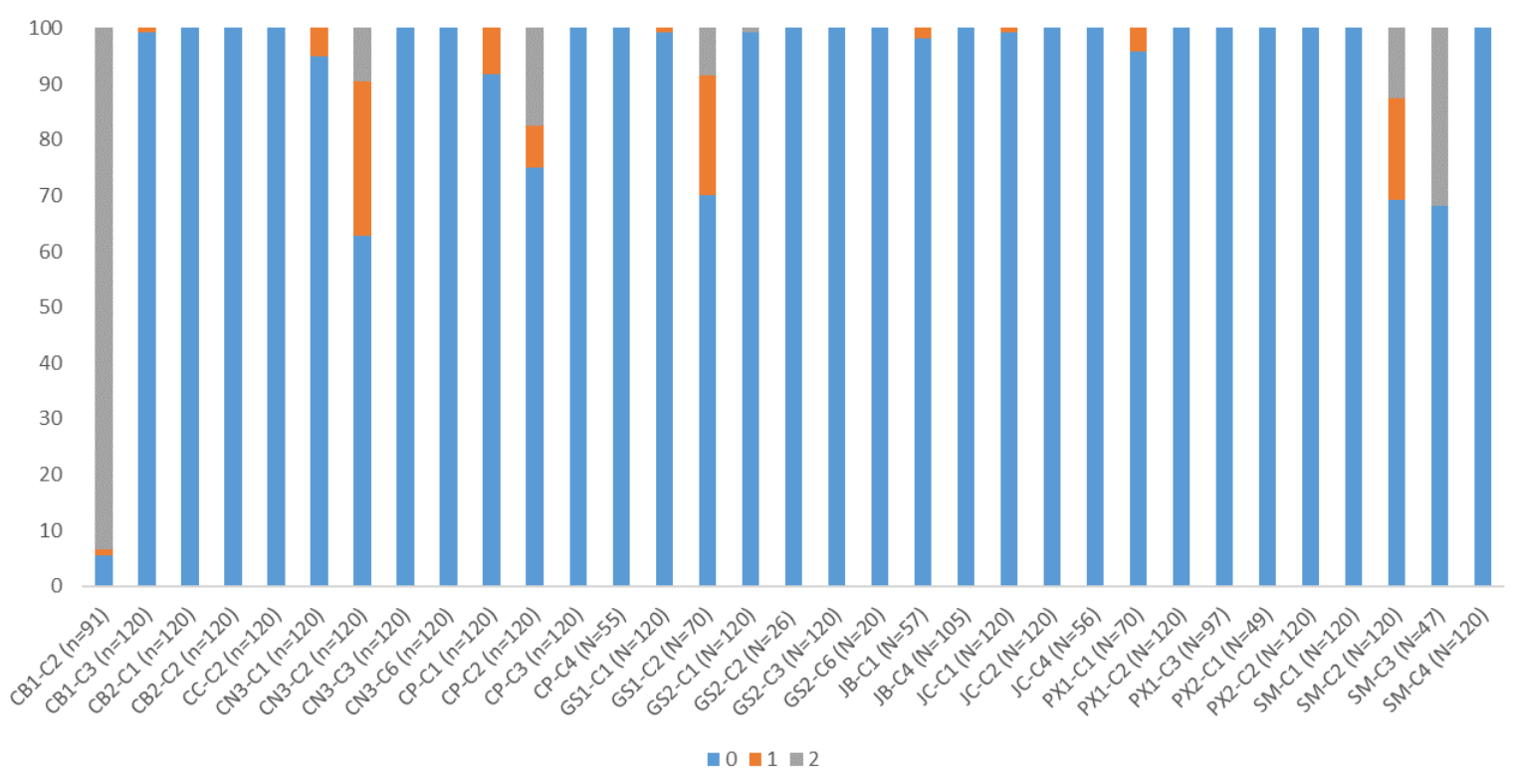

Figura 70. Graus de precipitação entre os sambaquis.

5.5.2 Evolução cronológica das assinaturas tafonômicas

A fim de comparar os depósitos paleolagunares e sambaquis quanto aos aspectos tafonômicos em função do tempo, foram utilizados os graus máximos (3) das assinaturas fragmentação, dissolução e oxidação e o grau mínimo (0) da oxidação (Figuras 71 a 74). Para as assinaturas de alteração superficial, considerou-se a alteração de superfície externa, cujo padrão mostrou-se similar ao da superfície interna. Em linhas gerais, os valores medianos das assinaturas tafonômicas variaram de modo similar, nos depósitos paleolagunares e nos sambaquis de mesma idade, porém com taxas de variação e picos diferentes. Ressalte-se, porém, que os valores 
de desvio padrão são elevados, o que faz com que afirmações seguras possam ser feitas somente com relação às tendências mais gerais de variação.

Com relação à fragmentação máxima, observa-se, na Figura 71 , que os depósitos paleolagunares mais antigos, entre 7 ka e 6,5 ka AP, possuem menor proporção de conchas fragmentadas quando comparados ao sambaqui de idade correspondente, o Caipora, cuja proporção de conchas quebradas aumenta com o tempo. Por volta de 5 ka, observa-se baixíssima frequência de conchas fragmentadas nos sambaquis em geral (mediana inferior a $5 \%$ ), com aumento progressivo ao longo do tempo, até cerca de 2,7 ka AP, quando se registra um pico de queda no registro de conchas fragmentadas. Desconsiderado este pico, porém, a tendência geral é de aumento progressivo da fragmentação grau 3 até aproximadamente 1,8 ka AP, tanto nos sambaquis, quanto, mais acentuadamente, nos depósitos paleolagunares. A partir de então, nota-se queda na proporção das conchas fragmentadas nos sambaquis. Neste último período de tempo, não se dispõe de informações sobre as conchas paleolagunares.

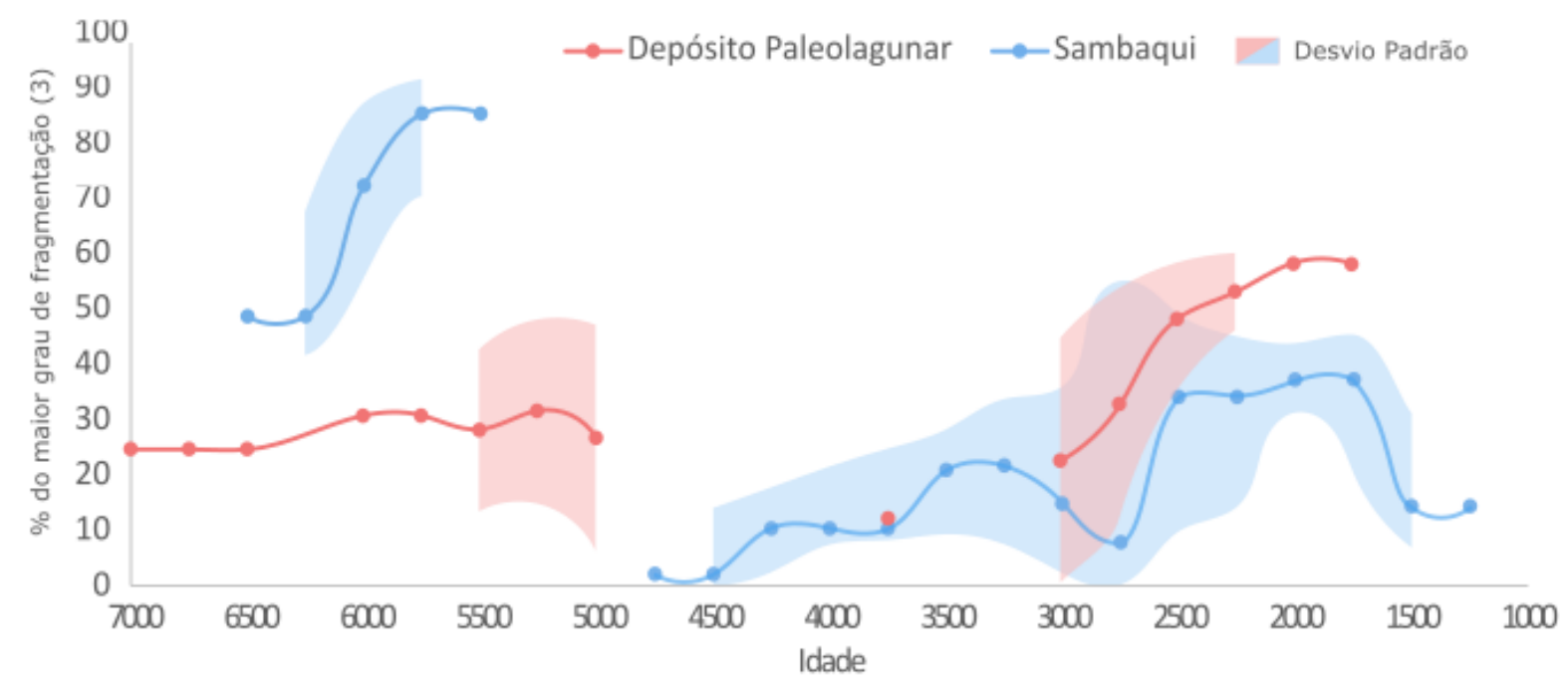

Figura 71. Comparação entre depósitos paleolagunares e sambaquis, ao longo do tempo, quando à frequência de conchas quebradas em grau máximo (3).

Com relação ao grau máximo de dissolução (Figura 72), nota-se tendência para valores medianos mais elevados nos concheiros naturais que nos sambaquis. Observam-se três picos de maior frequência de conchas com grau máximo de dissolução nos sambaquis, em 4 ka, 3 ka e 1,5 ka, e um pico nos depósitos naturais, em 2,5 ka, com queda a partir de então até o final do registro. 


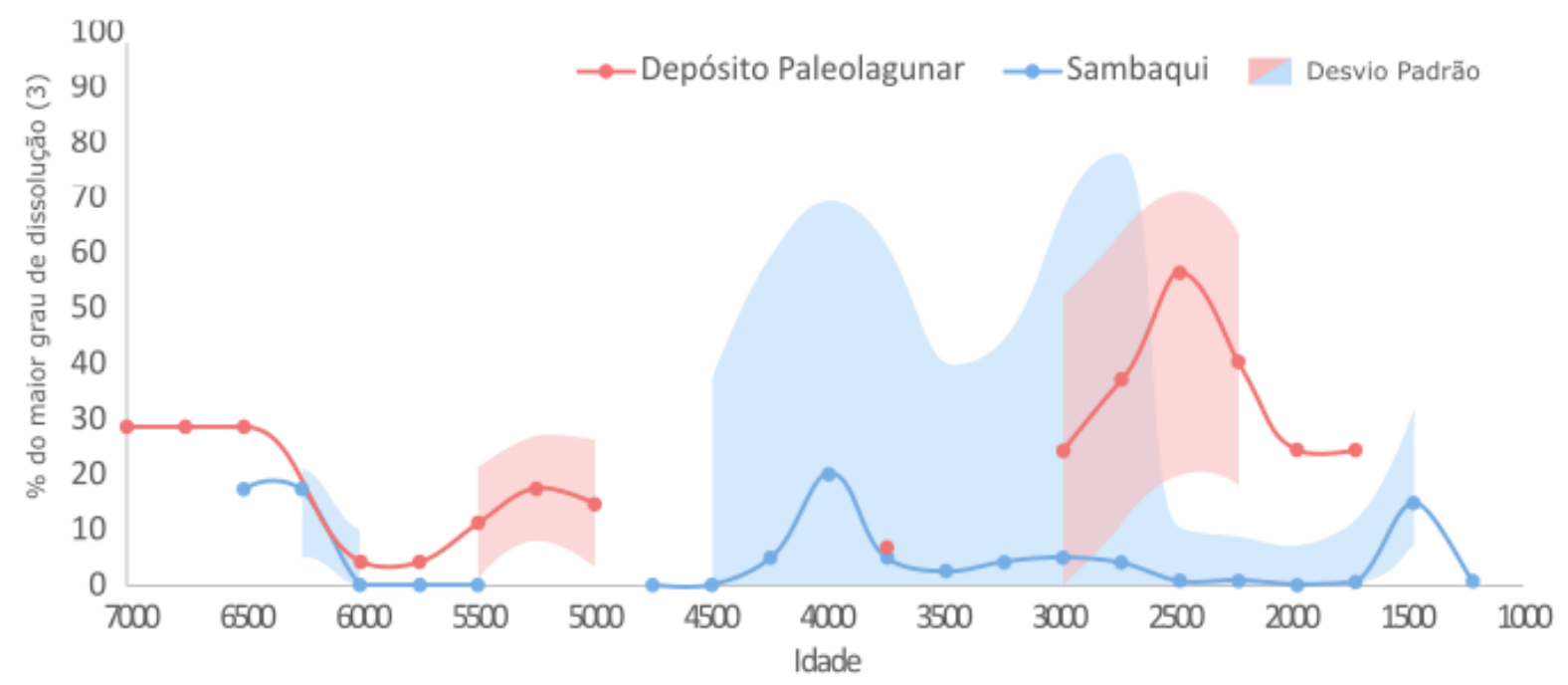

Figura 72. Comparação entre depósitos paleolagunares e sambaquis, ao longo do tempo, quando à frequência de conchas com dissolução em grau máximo (3).

A oxidação mostrou-se decrescente ao longo do espectro temporal analisado, exceto por picos em cerca de 4,8 ka, 3 ka e 2,5 ka, nos sambaquis (Figura 73). Valores elevados são observados também nos depósitos paleolagunares, com idade por volta de 6 ka.

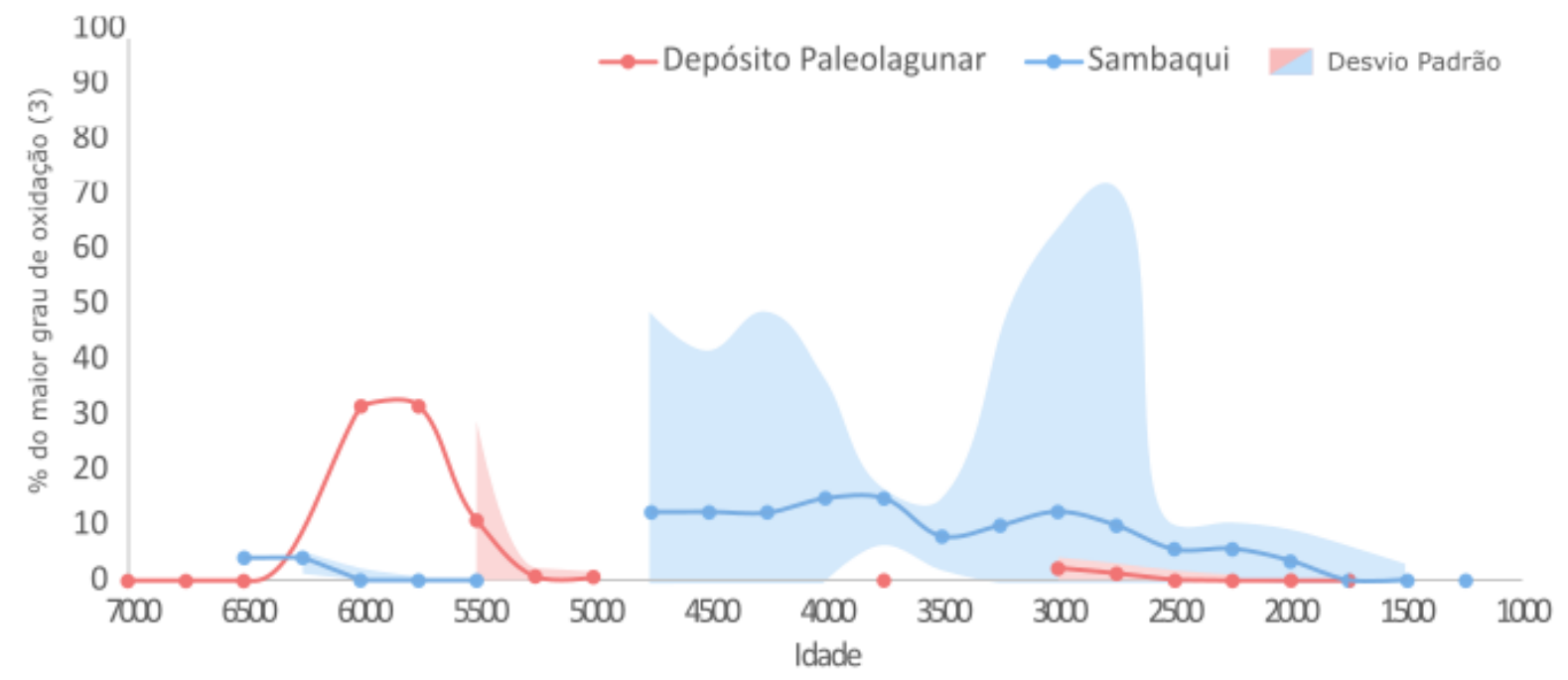

Figura 73. Comparação entre depósitos paleolagunares e sambaquis, ao longo do tempo, quando à frequência de conchas com oxidação em grau máximo (3).

Precipitação é a assinatura tafonômica que raramente aparece no registro, exceto por dois picos em cerca de $6 \mathrm{ka} \mathrm{e} 4 \mathrm{ka}$, esta última porém verificada apenas no valor médio referente aos sambaquis (Figura 74). 


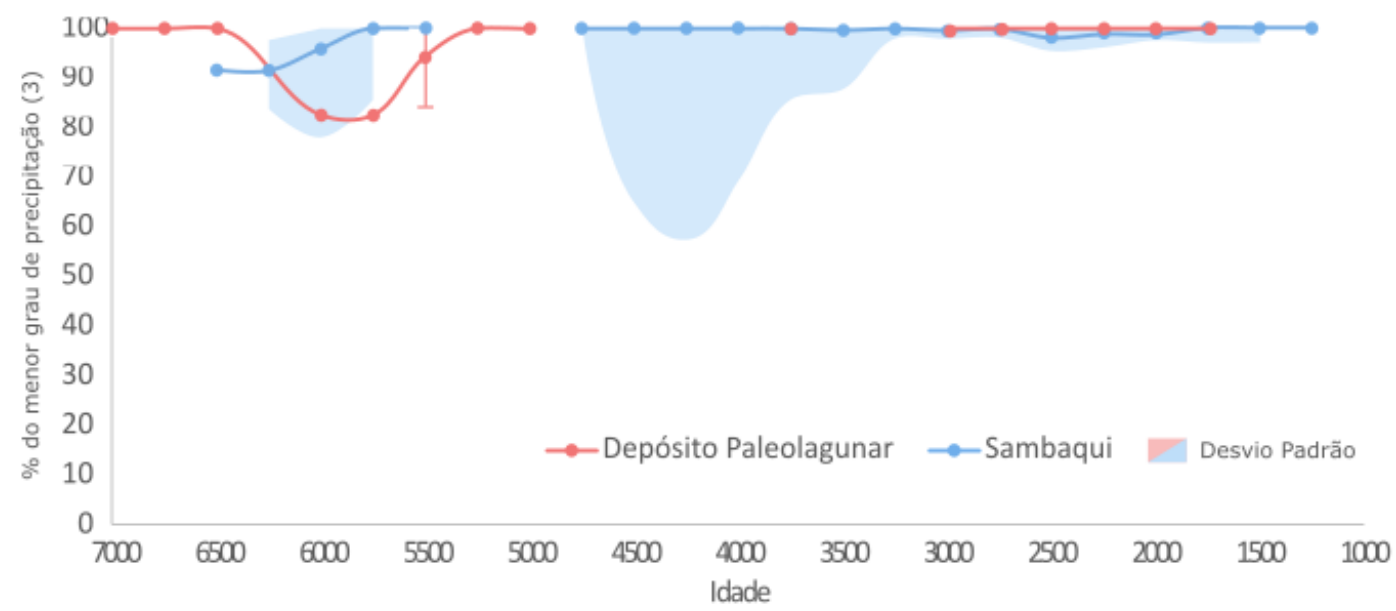

Figura 74. Comparação entre depósitos paleolagunares e sambaquis, ao longo do tempo, quando à frequência de conchas com precipitação em grau mínimo (0).

\subsubsection{Alteração superficial das conchas}

A análise por MEV-EDS da superfície corroída ou impregnada de conchas de A. brasiliana foi aplicada a cinco amostras de sambaquis (CB1-C2, CN3, GS2-C1, SMC2 e SM-C3) e a duas amostras de depósitos paleolagunares (CPL2-C1 e PXL-C1). A proposta desta análise foi caracterizar a textura e composição dos principais tipos descritivos de alteração superficial, listados na Tabela 7 , detectados na análise tafonômica das conchas dos depósitos naturais e arqueológicos.

Tabela 7. Tipos de alteração observados na superfície das conchas de sambaquis

\begin{tabular}{|c|c|c|c|}
\hline $\begin{array}{c}\text { Tipo de alteração } \\
\text { superficial }\end{array}$ & $\begin{array}{c}\text { Concha } \\
\text { analisada }\end{array}$ & Fácies & $\begin{array}{c}\text { Idade da camada } \\
\text { (anos }{ }^{14} \text { C cal AP) }\end{array}$ \\
\hline $\begin{array}{c}\text { Crosta amarelo- } \\
\text { alaranjada }\end{array}$ & CPL2-C1 & LaCpv & $5660-5880$ \\
\hline $\begin{array}{c}\text { Superfície } \\
\text { aparentemente limpa, } \\
\text { branco-azulada, porém } \\
\text { sem brilho original }\end{array}$ & PXL-C1 & CiALmo & $2762-2946$ \\
\hline $\begin{array}{c}\text { Crosta marrom } \\
\text { avermelhada }\end{array}$ & CB1-C2 & ACiq & $4077-4351$ \\
\hline $\begin{array}{c}\text { Manchas pretas em alto } \\
\text { relevo }\end{array}$ & CN3-C2 & CLAmo & $\begin{array}{c}2294-2459 \\
\text { (camada logo abaixo) }\end{array}$ \\
\hline $\begin{array}{c}\text { Manchas amarelo- } \\
\text { alaranjadas }\end{array}$ & GS2-C1 & AC & $\begin{array}{c}2853-3063 \\
2846-3053\end{array}$ \\
\hline Crosta pardo-amarelada & SM-C2 & ACiq & $\begin{array}{c}4309-4532 \\
\text { (camada logo abaixo) }\end{array}$ \\
\hline Crosta preta & SM-C3 & CqA & $3632-3849$ \\
\hline
\end{tabular}




\section{Crosta amarelo-alaranjada - concha CPL2-C1}

Ao MEV, a crosta amarelo-alaranjada (Figura 75 A) desta concha paleolagunar é aparentemente espessa (maior que $200 \mu \mathrm{m}$ ) e com relevo irregular, formada dominantemente por massa de argilominerais, cujo hábito lembra esmectita, mas com pico acentuado de $\mathrm{K}$, atribuído à provável associação com illita. Em meio a ela, encontraram-se uma roseta de gipsita (Figura 75 B) e abundantes frústulas de diatomáceas da espécie Paralia sulcata (Ehrenberg) Cleve, 1873, com até cerca de $20 \mu \mathrm{m}$ (Figura $76 \mathrm{C}, \mathrm{D}$ ).
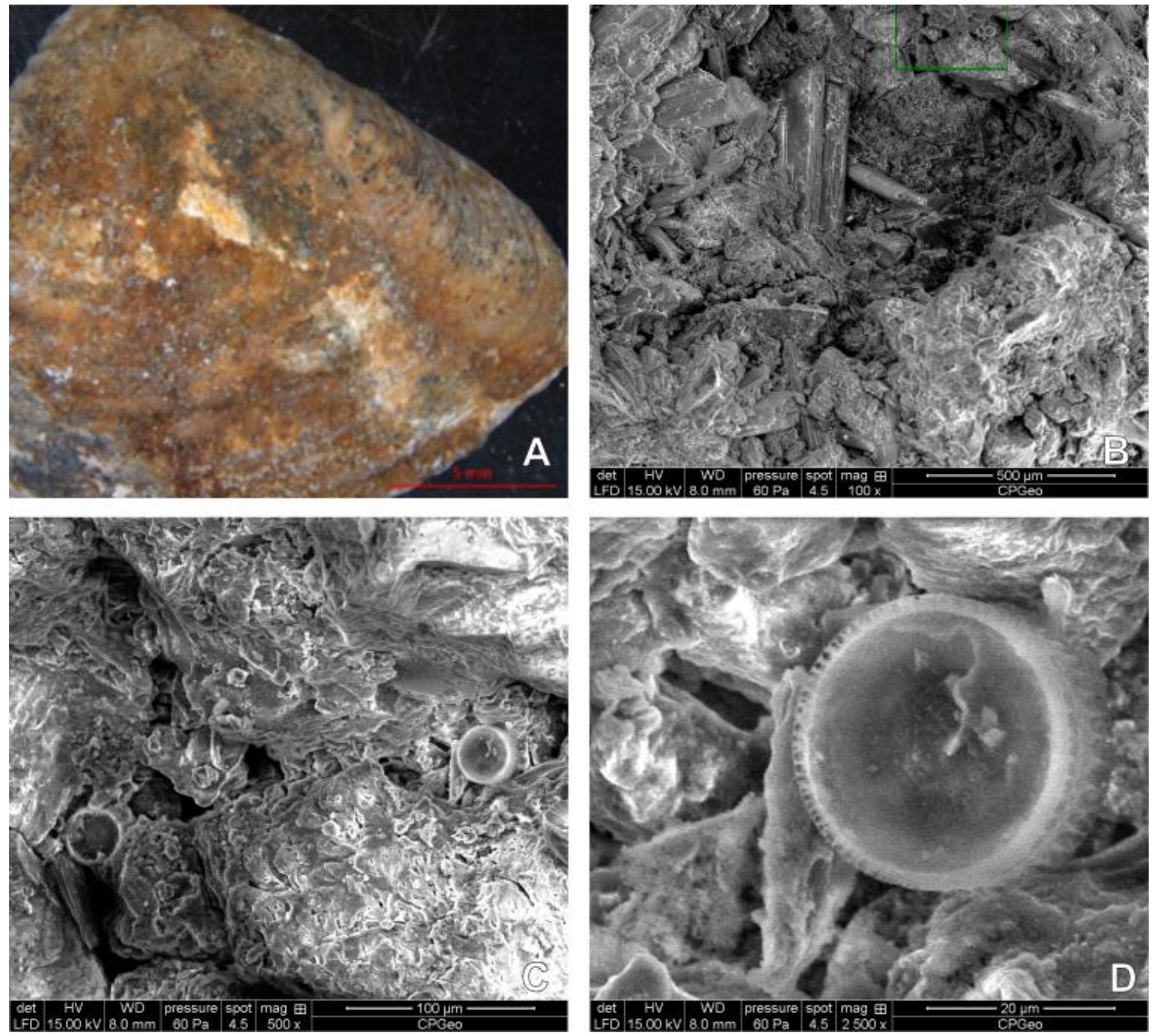

Figura 75. Análise da alteração superficial de uma concha de $A$. brasiliana da camada 1 do depósito paleolagunar Caipora (CPL2-C1): A) superfície da concha com crosta amarelo-alaranjada; B) roseta de gipsita em meio à massa de argilominerais; $\mathrm{C}$-D) frústulas de diatomáceas (Paralia sulcata) em meio a argilominerais. 


\section{Superfície aparentemente limpa, branco-azulada, porém sem brilho original - concha PXL-C1}

A concha PXL-C1, que a olho nu aparenta ser livre de impregnações (Figura 76 A), demonstrou ao MEV possuir uma crosta de calcita micrítica, com indícios (picos diminutos de Si e Al) de presença de argilominerais. Pela disposição em relação ao substrato da concha e pela íntima associação com os argilominerais, esta crosta devese provavelmente à reprecipitação eodiagenética. Sobre ela, observam-se orifícios subcirculares com 2 a $20 \mu \mathrm{m}$ de diâmetro, e, mais raramente, calhas alongadas de dimensões parecidas (Figura 76 B, C), feições que apontam para dissolução superimposta, mas que podem também, alternativamente, resultarem do processo de precipitação.
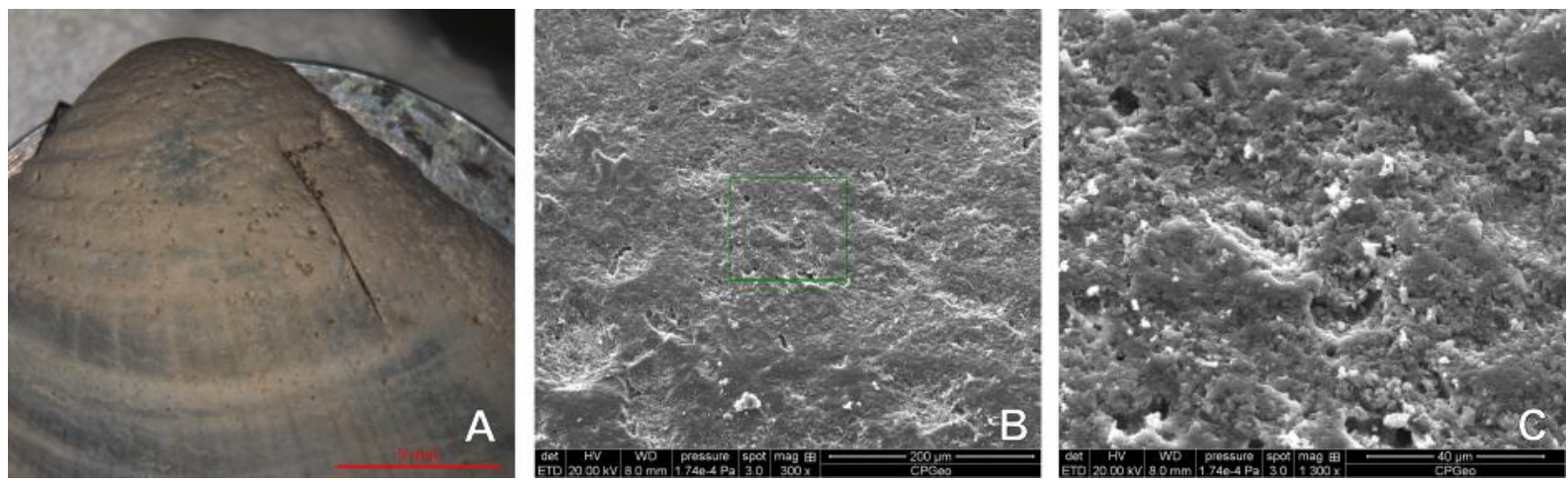

Figura 76. Análise da alteração superficial de uma concha de $A$. brasiliana da camada 1 do depósito paleolagunar Perrixil (PXL-C1): A) superfície da concha branco-azulada, sem brilho original; B-C) crosta de reprecipitação de calcita (contendo impurezas de argilominerais) com orifícios circulares e, mais raramente, calhas alongadas.

\section{Crosta marrom avermelhada - concha CB1-C2}

No mapeamento químico da crosta marrom avermelhada (Figura 77 A, B), a distribuição homogênea da maioria dos elementos indica composição uniforme, exceto por concentrações pontuais de $\mathrm{Si}, \mathrm{C}, \mathrm{K}, \mathrm{Fe}, \mathrm{Ti}$ e $\mathrm{Mn}$, associadas a ocorrência de grãos de areia aderidos (Figura $77 \mathrm{C}$ ) de quartzo (Si), carvão $(\mathrm{C})$, feldspato $(\mathrm{K})$ e óxi-hidroxidos metálicos ( $\mathrm{Fe}, \mathrm{Ti}, \mathrm{Mn})$, dentre os quais se confirmou a presença de ilmenita.

A presença constante, em ampla área, de $\mathrm{Si}, \mathrm{Al}$ e $\mathrm{P}$, além do $\mathrm{Ca}$, indica que a crosta é constituída por uma mistura de argilominerais e, dominantemente, apatita, a qual ocorre como agregados fibrorradiados de prismas e agulhas, com até $40 \mu \mathrm{m}$ de diâmetro (Figura 77 D, E, F), e também na forma de sucessivas camadas fosfamicríticas, paralelas à superfície da concha e envolvendo os grãos de areia, 
constituídas por cristais perpendiculares de menos de $3 \mu \mathrm{m}$ de comprimento (Figura 77 G). A esta segunda forma de ocorrência da apatita, associam-se crateras em padrão fractal (Figura $77 \mathrm{H}$ ), sugestivas de dissolução parcial, possivelmente por soluções ácidas.
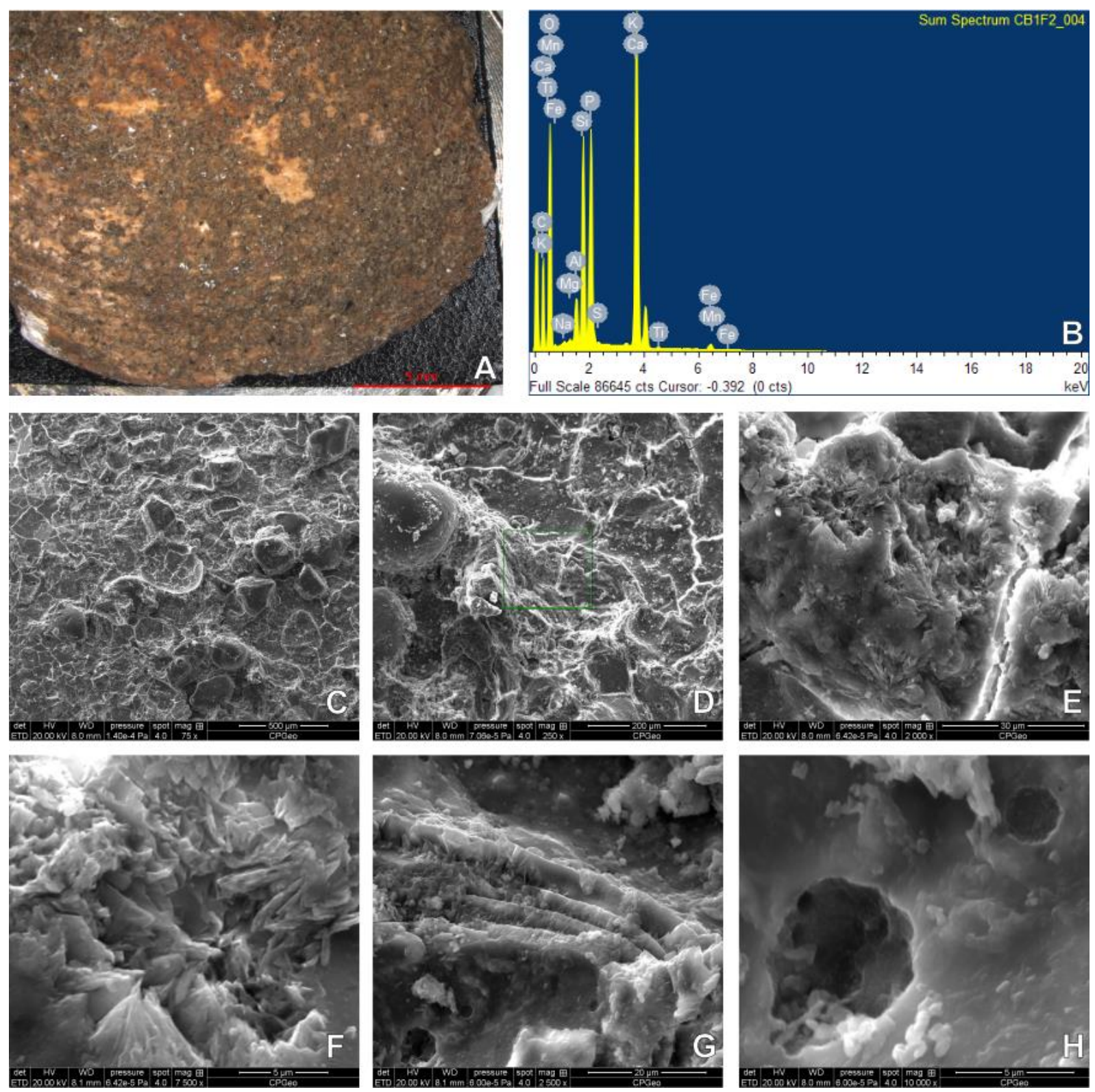

Figura 77. Análise da alteração superficial de uma concha de $A$. brasiliana da camada 2 do sambaqui

Cabeçuda (CB1-C2): A) crosta marrom avermelhada apresentando grãos de areia aderidos; B) espectro típico da associação entre apatita $(\mathrm{P}, \mathrm{Ca})$ e argilominerais $(\mathrm{Si}, \mathrm{Al}, \mathrm{Mg}, \mathrm{K}) ; \mathrm{C})$ grãos de areia aderidos à superfície da concha; D-F) argilominerais e, dominantemente, apatita, a qual ocorre como agregados fibrorradiados de prismas e agulhas, com até $40 \mu \mathrm{m}$ de diâmetro; G) camadas, paralelas à superfície da concha e envolvendo os grãos de areia, constituídas por cristais perpendiculares de apatita de menos de $3 \mu \mathrm{m}$ de comprimento (fosfamicrita); H) crateras em padrão fractal sugestivas de dissolução parcial da crosta de apatita. 


\section{Manchas pretas em alto relevo - concha CN3-C2}

As manchas de cor preta ocorrem aparentemente como impregnações sobre a superfície branca da concha (Figura 78 A). A microanálise química por EDS destas manchas mostrou enriquecimento de $\mathrm{C}$ e empobrecimento de $\mathrm{Ca}$, o que permitiu interpretar a impregnação como calcita reprecipitada, enriquecida em matéria orgânica. Nos locais em que cristais prismáticos de calcita são visíveis em meio à crosta, o pico de Ca aumenta, em detrimento do de C (Figura 78 B). Grãos de quartzo e feldspato ocorrem aderidos. Localmente, o material reprecipitado forma faixas alongadas e sinuosas de $50 \mu \mathrm{m}$ de largura por até $1 \mathrm{~mm}$ de extensão (Figura 78 C, D), nos quais se identificaram filamentos, com até $50 \mu \mathrm{m}$ de comprimento, de possível composição carbonosa (Figura $78 \mathrm{E}$ ).
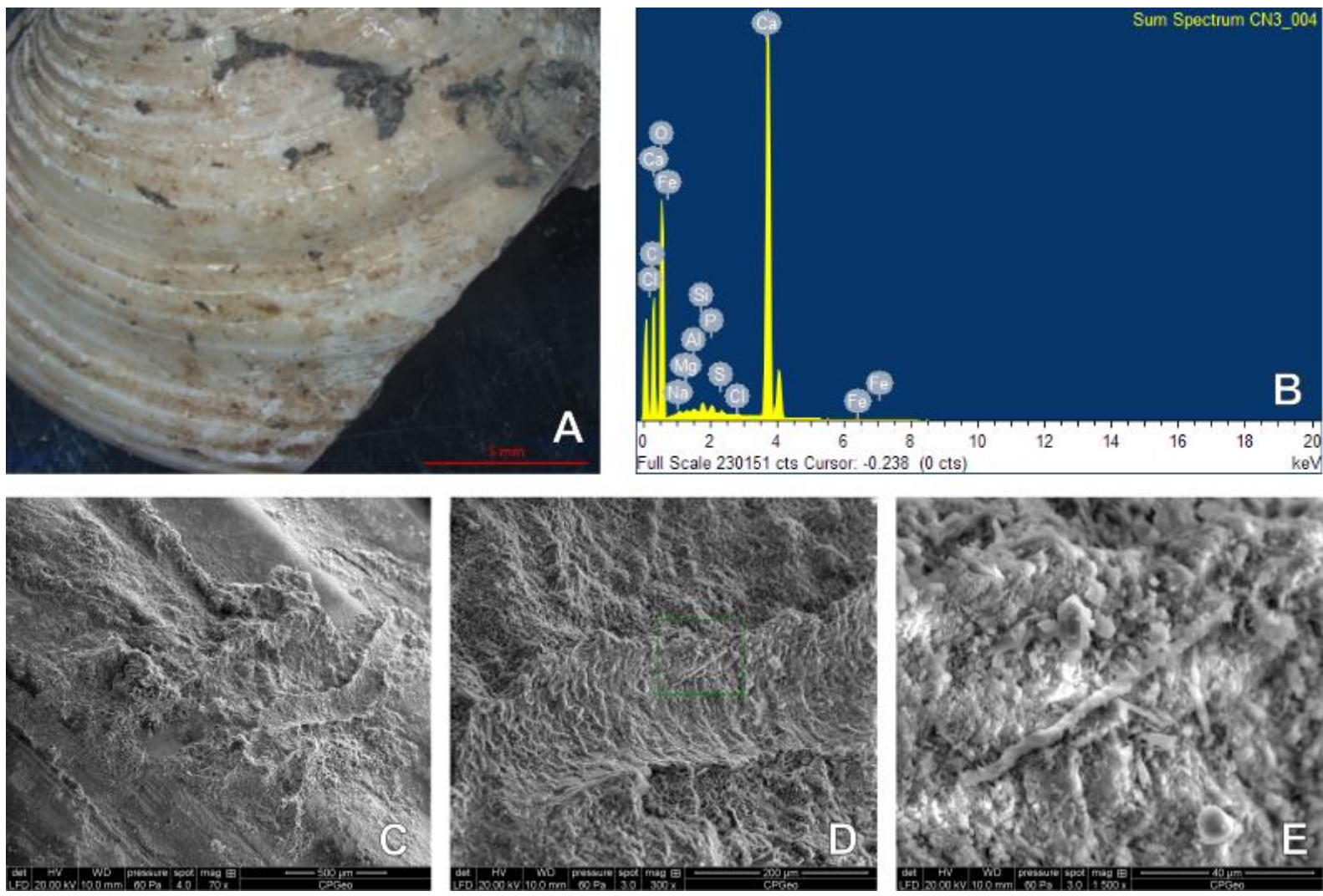

Figura 78. Análise da alteração superficial de uma concha de $A$. brasiliana da camada 2 do sambaqui Carniça 3 (CN3-C2): A) impregnações de cor preta sobre a superfície branca da concha; B) microanálise química por EDS de cristais prismáticos de calcita visíveis em meio às zonas pretas, com enriquecimento de $\mathrm{Ca}$ e empobrecimento de $\mathrm{C}$ em relação ao restante da crosta; C-D) material reprecipitado, formando faixas alongadas e sinuosas de $50 \mu \mathrm{m}$ de largura por até $1 \mathrm{~mm}$ de extensão;

E) filamentos, com até $50 \mu \mathrm{m}$ de comprimento, de possível composição carbonosa. 


\section{Manchas amarelo-alaranjadas - concha GS2-C1}

A superfície da concha GS2-C1 exibe uma crosta (Figura 79 A) de apatita associada a argilominerais, de aspecto coloidal, gretado (Figura $79 \mathrm{~B}$ ), que, sob maior aumento, mostra a presença de tufos de cristais prismáticos (possível fosfamicrita) com até $5 \mu \mathrm{m}$ (Figura $79 \mathrm{C}$ ).
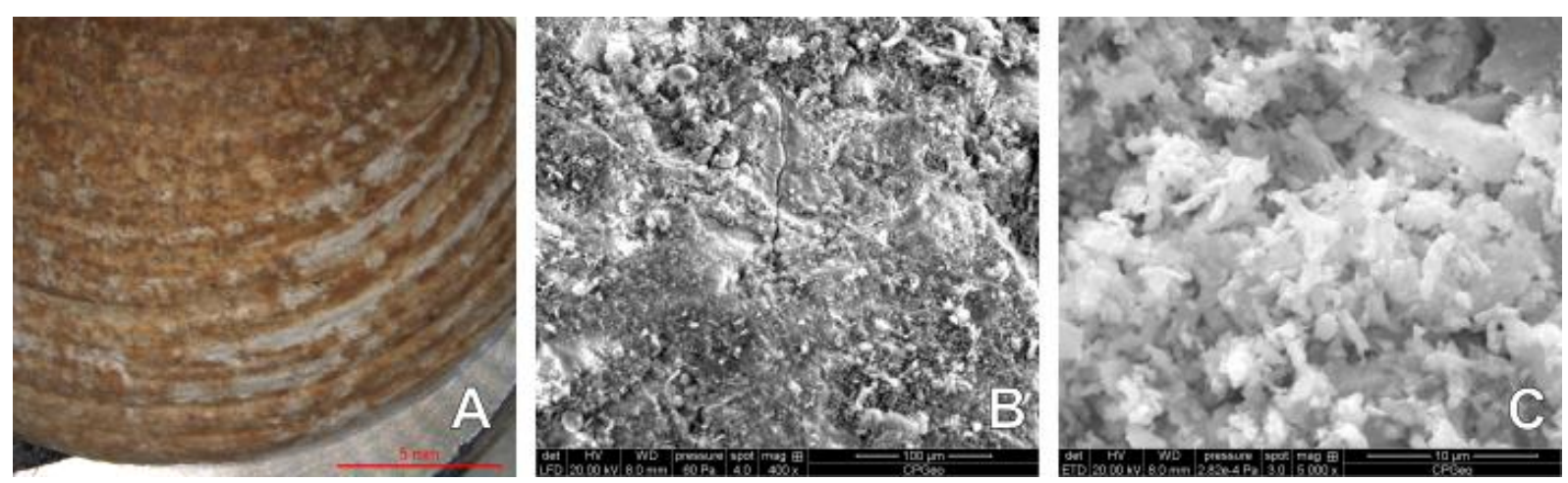

Figura 79. Análise da alteração superficial de uma concha de $A$. brasiliana da camada 1 do sambaqui Garopaba do Sul (GS2-C1): A) superfície com crosta amarelo-alaranjada; B) crosta de apatita associada a argilominerais, de aspecto coloidal, gretado; C) tufos de cristais prismáticos.

\section{Crosta pardo-amarelada - concha SM-C2}

O mapeamento químico da concha SM-C2 (Figura 80 A, B) mostrou presença marcante de $\mathrm{P}, \mathrm{Ca}, \mathrm{Cl}, \mathrm{F}$, os quais variam juntos, sugerindo associação com flúorapatita e/ou cloro-apatita. A crosta de apatita é criptocristalina, dominantemente coloidal (colofânica), revestida em padrão drusiforme por cristais maiores do mesmo mineral (Figura $80 \mathrm{C}$ ). Elevações localizadas nos teores de $\mathrm{C}, \mathrm{Al}, \mathrm{Si}, \mathrm{e}$, subordinadamente, de $\mathrm{Fe}, \mathrm{Mg}, \mathrm{K}$ e Na , associam-se a cavidades na crosta de apatita, as quais estariam preenchidas por complexo argilo-orgânico, de baixa cristalinidade e/ou criptocristalino; a composição deste complexo sugere presença de esmectita e illita, o que foi reforçado pela identificação de cristais, ainda que mal formados, com hábito em folhas de alface e com fibras na terminação (Figura $80 \mathrm{D}$ ). Também foram identificados cristais prismáticos a aciculares com até cerca de $15 \mu \mathrm{m}$ de comprimento (Figura $80 \mathrm{E}, \mathrm{F}$ ) 

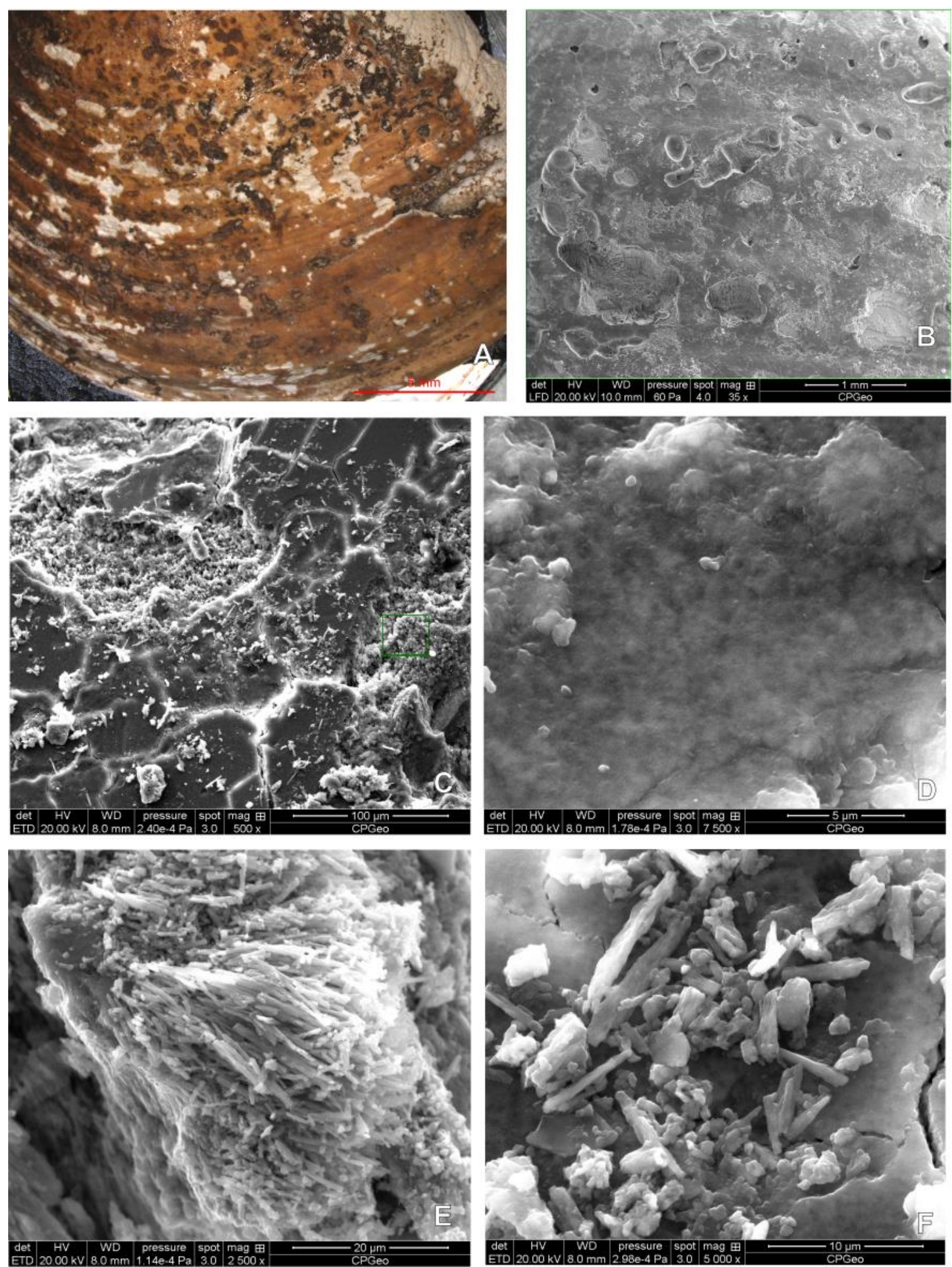

Figura 80. Análise da alteração superficial de uma concha de $A$. brasiliana da camada 2 do sambaqui Santa Marta 2 (SM-C2): A) superfície da concha com crosta de impregnação pardo-amarelada; B) presença marcante, nesta crosta, de $\mathrm{P}, \mathrm{Ca}, \mathrm{Cl}, \mathrm{F}$, os quais variam juntos, sugerindo associação com flúor-apatita e/ou cloro-apatita; C) aspecto geral da crosta de apatita criptocristalina, revestida em padrão drusiforme por cristais maiores do mesmo mineral; D) cristais com hábito em folhas de alface e com fibras na terminação (possível presença de esmectita e illita; E e F) detalhes dos cristais prismáticos de apatita com até cerca de $15 \mu \mathrm{m}$ de comprimento.). 


\section{Crosta preta - concha SM-C3}

O mapeamento químico da crosta sobre a concha SM-C3 (Figura $81 \mathrm{~A}, \mathrm{~B}$ ) mostrou Si em padrão de distribuição "pipocado" (Figura $81 \mathrm{C}$ ), devido à grande quantidade de grãos de quartzo aderidos. Nas porções entre grãos, o predomínio é de $\mathrm{P}, \mathrm{Ca}$ e C, com ocorrência simultânea de concentrações menores de $\mathrm{Si}$, Al e Fe, o que indica composição fosfática (apatita) associada a material argilo-orgânico ferruginoso. A apatita ocorre sob pelo menos quatro formas: coloidal; de prismas curtos micríticos a microespáticos (Figura 81 D); de esferólitos com cerca de $15 \mu \mathrm{m}$ de diâmetro (Figura $82 \mathrm{E})$; e de agregados de minúsculos grãos elipsoides $(\sim 1 \mu \mathrm{m})$, que lembram bacilos associados a fibras vegetais intimamente aderidas à superfície da crosta (Figura $81 \mathrm{~F}, \mathrm{G}, \mathrm{H}$ ).
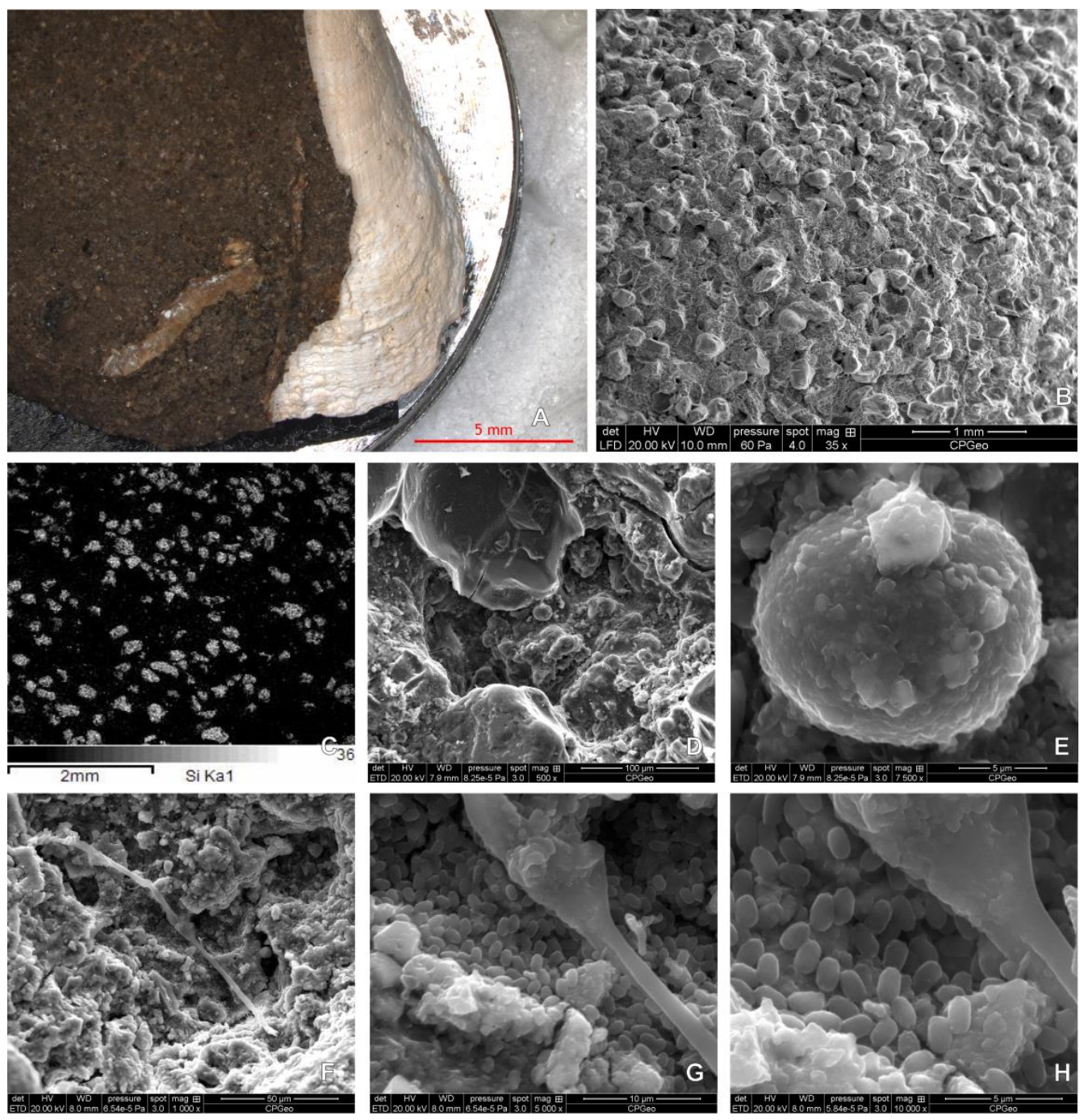

Figura 81. Análise da alteração superficial de uma concha de $A$. brasiliana da camada 3 do sambaqui Santa Marta 2 (SM-C3): A) superfície da concha com crosta preta; B) crosta de apatita e argilominerais, com grãos de areia terrígena (sobretudo de quartzo) aderidos; C) Si em padrão de distribuição "pipocado";

D) prismas curtos cripto a microcristalinos de apatita; E) esferólito de apatita, com cerca de $15 \mu \mathrm{m}$ de diâmetro; F-H) agregados de minúsculos grãos elipsoides $(\sim 1 \mu \mathrm{m})$, que lembram bacilos e fibras vegetais intimamente aderidas à crosta na superfície da concha. 


\subsection{Isótopos estáveis e geoquímica}

\section{$5.6 .1 \delta^{18} \mathrm{O}$}

$\mathrm{O} \delta^{18} \mathrm{O}$ das conchas de $A$. brasiliana analisadas varia de $-0,75 \%$ até $-1,94 \%$, com valor médio de $-1,42 \%$ (Figura 82 ). $O$ valor mais alto é registrado em cerca de 5,2 ka AP, com pico subordinado em 7 ka AP, e o valor mais baixo, em torno de 1,5 ka AP. Nota-se tendência de queda dos valores medianos no decorrer do tempo coberto pela amostragem, só que em dois intervalos: de 7 ka a 5,5 ka AP; e de 5,0 ka AP a 1,5 ka AP, neste caso com aumento da dispersão, representada pelo desvio padrão, ao longo do tempo. Os valores mais elevados de dispersão encontram-se, porém, nas amostras mais antigas (anteriores a $6 \mathrm{ka}$ ).

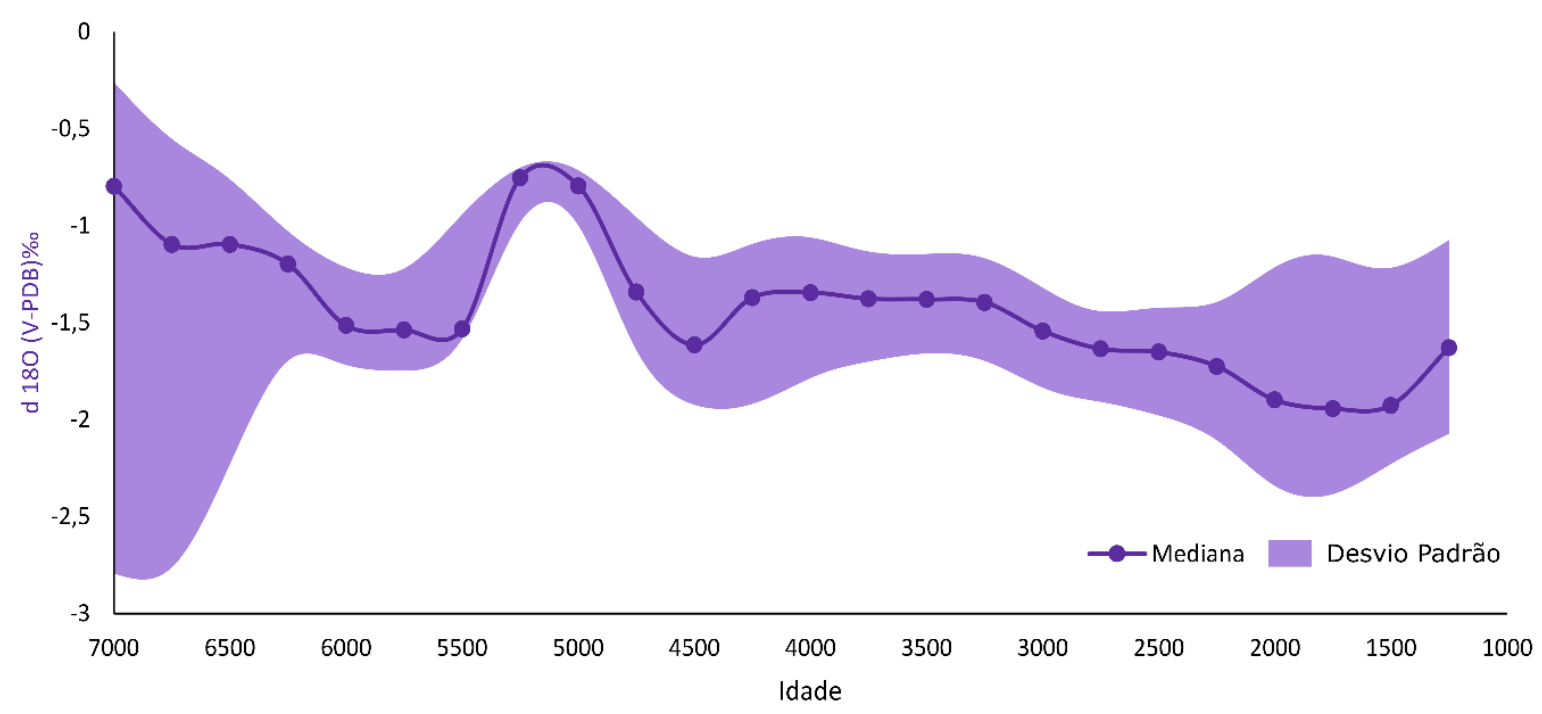

Figura 82. Valores de $\delta^{18} \mathrm{O}(\mathrm{V}-\mathrm{PDB}) \%$ em conchas de sambaquis e de depósitos paleolagunares ao longo do tempo. $N=99$. $R=0,429 ; P=0,005$.

\section{$5.6 .2 \delta^{13} \mathrm{C}$}

$\mathrm{O} \delta^{13} \mathrm{C}$ das conchas de $A$. brasiliana analisadas varia de cerca de $-0,01 \%$ até 1,67\%, com valor médio de $0,75 \%$ (Figura 83). O valor mais alto é registrado em 7 ka AP, com picos menores em 6,2 ka AP e 4,5 ka AP, e o valor mais baixo ocorre em 1,5 ka AP. A exemplo do $\delta^{18} \mathrm{O}$, existe tendência de queda dos valores medianos no decorrer do tempo, mais acentuada nos últimos $4,5 \mathrm{ka}$, porém com aumento na dispersão dos valores a partir de 2,5 ka AP. Também a exemplo do $\delta^{18} \mathrm{O}$, a dispersão de dados aumenta nos dois extremos do intervalo total de tempo. 


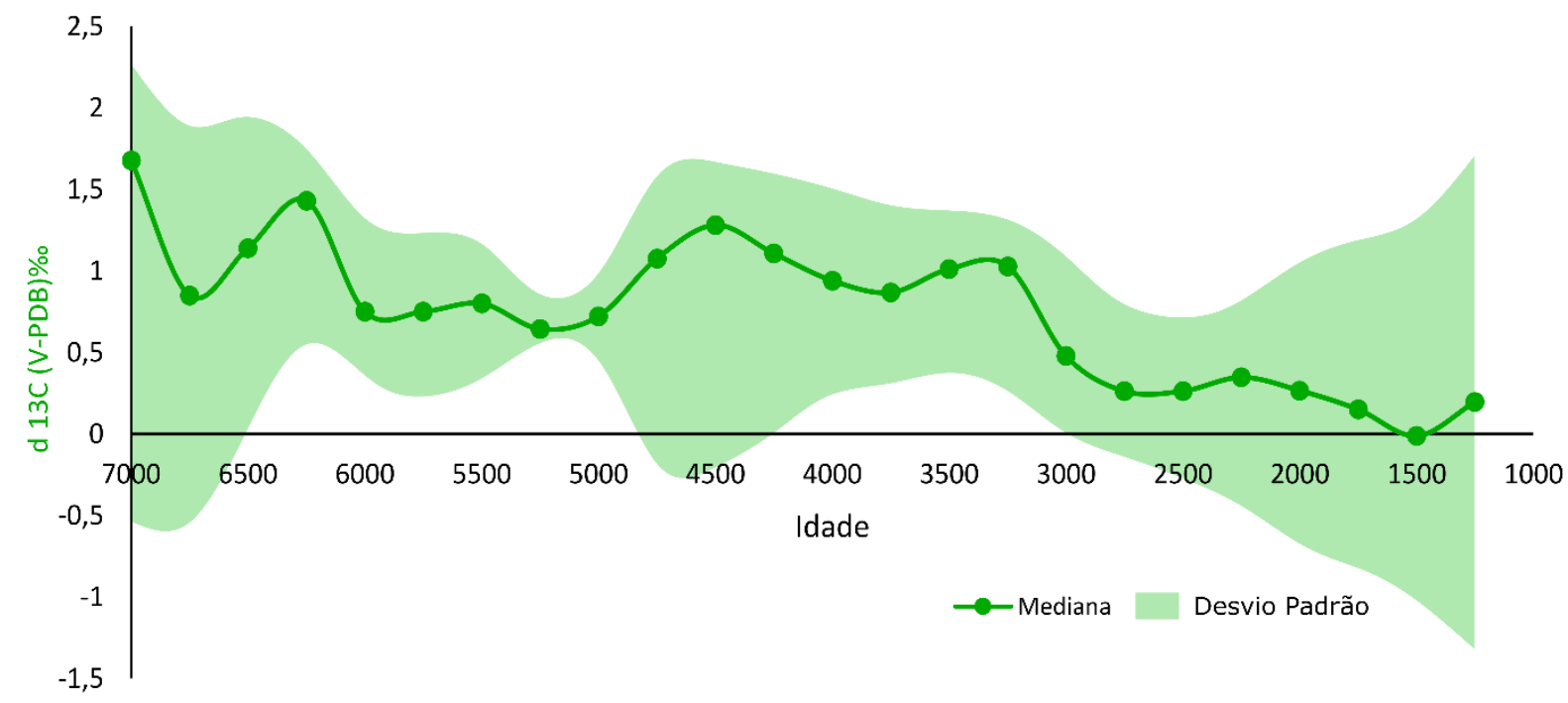

Figura 83. Valores de $\delta^{13} \mathrm{C}(\mathrm{V}-\mathrm{PDB}) \%$ em conchas de sambaquis e de depósitos paleolagunares ao longo do tempo. $\mathrm{N}=99$. $\mathrm{R}=0,762 ; \mathrm{P}=0,005$.

\subsubsection{Mg/Ca}

Os valores de $\mathrm{Mg} / \mathrm{Ca}$ das conchas de $A$. brasiliana analisadas variam de $0,29 \mathrm{mmol} / \mathrm{mol}$ até $0,61 \mathrm{mmol} / \mathrm{mol}$, com valor médio de $0,5 \mathrm{mmol} / \mathrm{mol}$ (Figura 84 ). $O$ valor mais alto é registrado entre 4,75 e $5 \mathrm{ka} \mathrm{AP,} \mathrm{com} \mathrm{picos} \mathrm{menores} \mathrm{em} \mathrm{3,5} \mathrm{ka} \mathrm{AP,} 7$ ka AP e 1,5 ka AP, e o valor mais baixo ocorre em 6,25 ka AP. A dispersão de dados varia relativamente pouco ao longo do intervalo temporal.

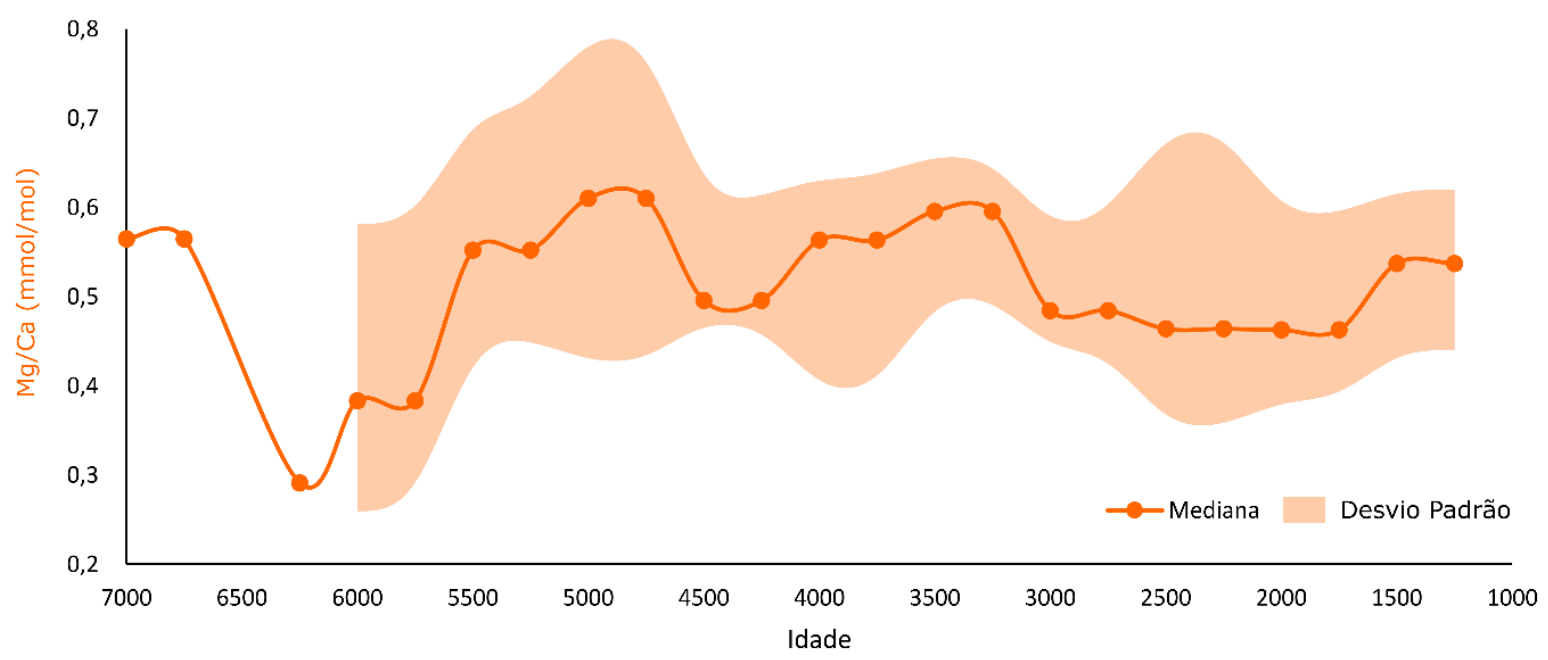

Figura 84. Variação da razão $\mathrm{Mg} / \mathrm{Ca}$ em conchas de sambaquis e de depósitos paleolagunares ao longo do tempo. $\mathrm{N}=99$. $\mathrm{R}=-0,098$. 


\subsection{4 $\mathrm{Sr} / \mathrm{Ca}$}

Os valores de $\mathrm{Sr} / \mathrm{Ca}$ das conchas de $A$. brasiliana analisadas variam de $1,24 \mathrm{mmol} / \mathrm{mol}$ até $1,73 \mathrm{mmol} / \mathrm{mol}$, com valor médio de $1,43 \mathrm{mmol} / \mathrm{mol}$ (Figura 85 ). Os valores mais altos se concentram entre 1,25 ka AP e 2,25 ka AP, com picos menores em 7 ka AP, 6,75 ka AP, 5,5 ka AP e 5 ka AP, e o valor mais baixo ocorre em 5,75 ka AP. A dispersão de dados é aproximadamente constante ao longo do intervalo temporal, com sutil aumento em 1,75 ka AP.

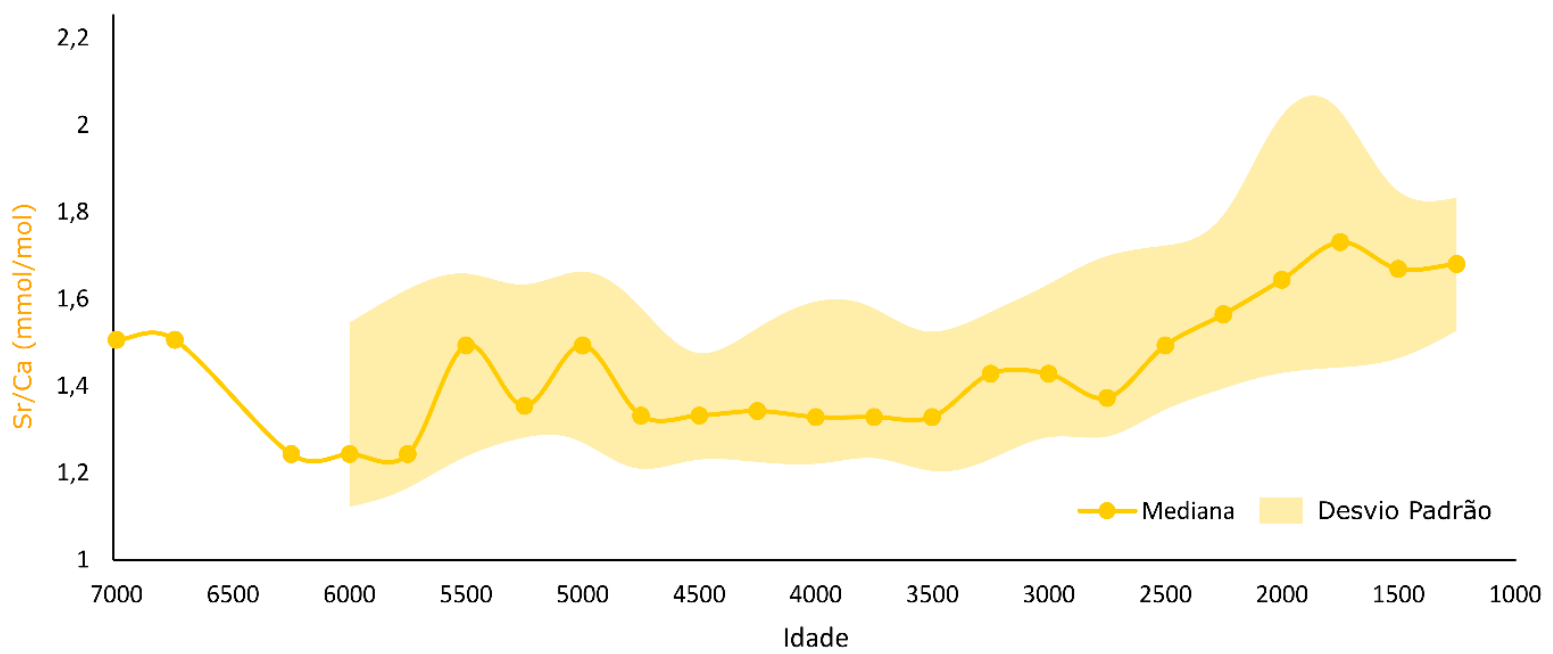

Figura 85. Variação da razão $\mathrm{Sr} / \mathrm{Ca}$ em conchas de sambaquis e de depósitos paleolagunares ao longo do tempo. $\mathrm{N}=99$. $\mathrm{R}=-0,638$. 


\subsubsection{Ba/Ca}

Os valores de $\mathrm{Ba} / \mathrm{Ca}$ das conchas de $A$. brasiliana analisadas variam de $5,10 \mathrm{mmol} / \mathrm{mol}$ até $9,4 \mathrm{mmol} / \mathrm{mol}$, com valor médio de $6,71 \mathrm{mmol} / \mathrm{mol}$ (Figura 86 ). Os valores mais altos se encontram em 5 ka AP, 4,5 ka AP, 3 ka AP e 2 ka AP, e o valor mais baixo ocorre em 1,5 ka AP. A dispersão de dados aumenta nas amostras mais jovens.

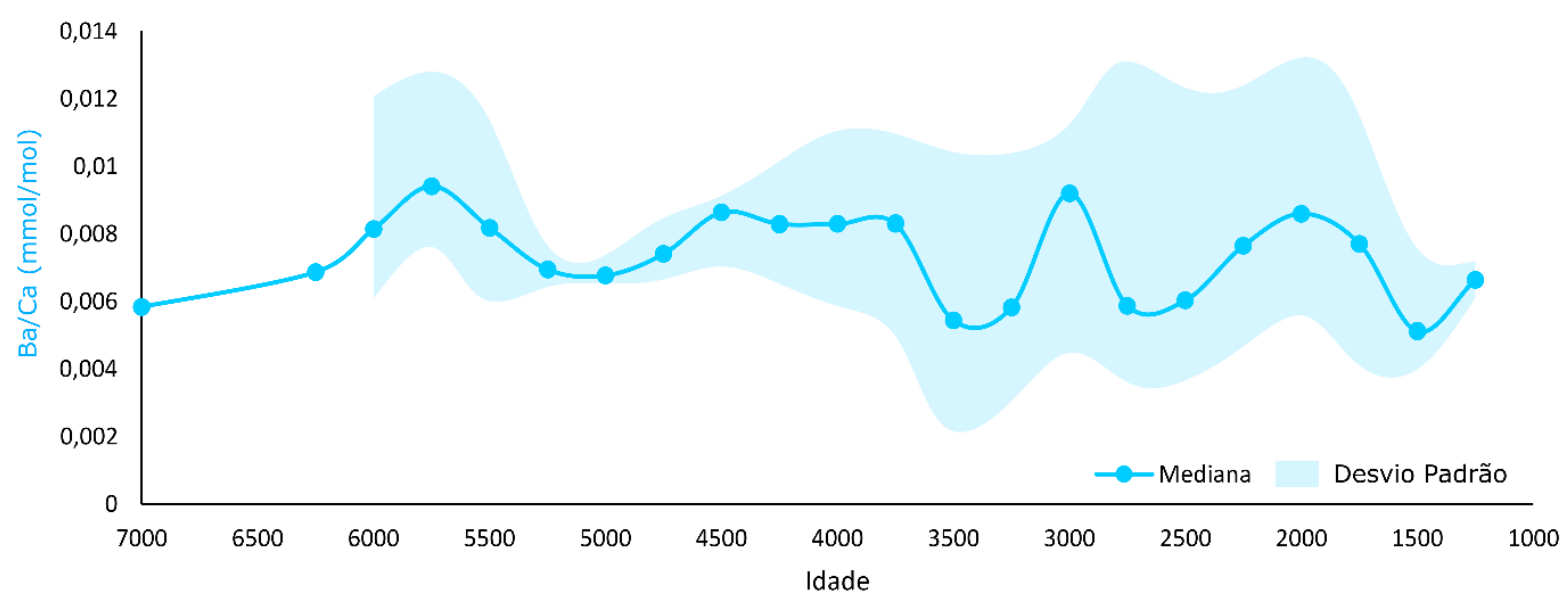

Figura 86. Variação da razão $\mathrm{Ba} / \mathrm{Ca}$ em conchas de sambaquis e de depósitos paleolagunares ao longo do tempo. $\mathrm{N}=99$. $\mathrm{R}=0,07$. 


\section{DISCUSSÃO}

\subsection{Distribuição das idades}

A concordância, dentro do intervalo de precisão do método ${ }^{14} \mathrm{C}$, entre idades de carvão e concha coletadas em mesmo nível ou camada, nos sambaquis, foi verificada em $73 \%$ das datações pareadas. Ela demonstra que as conchas dos sambaquis são, na maior parte dos casos, contemporâneas às fogueiras que se supõe terem gerado os carvões e, portanto, contemporâneas à ocupação. Esta interpretação é reforçada pelo baixo número de idades de um mesmo seção com inversão estratigráfica, como já havia sido verificado previamente na malha de datações obtida no sítio Jaboticabeira 2 (Bendazzoli, 2007; DeBlasis et al., 2007; Menezes, 2009). Nos dados desta tese, o sambaqui Perrixil é a grande exceção a esta regra, com inversões em suas duas seções e também entre elas. Este conjunto de evidências permite interpretar também que, excluído o caso do Perrixil, as conchas utilizadas na construção dos depósitos arqueológicos da região, ou, pelo menos, as conchas inteiras e não desgastadas, que foram as preferidas na datação, eram extraídas do fundo lagunar ativo na época da ocupação e não de depósitos (naturais ou arqueológicos) preexistentes, séculos mais antigos. Nos três casos de discrepância de idade entre concha e carvão, encontrou-se concha mais nova (até 485 anos) que carvão em dois deles, o que permite suspeitar de imprecisão na calibração (por exemplo, na correção do efeito reservatório da concha - Angulo et al., 2005) ou de reprecipitação diagenética de calcita, contaminada por carbono mais jovem oriundo do solo. A favor desta segunda hipótese, na análise ao MEV, mesmo conchas aparentemente limpas, porém com perda do brilho original, demonstraram a presença de uma crosta delgada de calcita reprecipitada (Figura 14).

O terceiro caso de discrepância concha-carvão requer interpretação completamente diferente, já que: 1. a discrepância é muito maior (até 1748 anos); 2. refere-se ao sítio Perrixil, onde, como já mencionado, existem inversões estratigráficas. Neste caso, portanto, a interpretação sugerida é a de que a concha (PX2-C3, com 3290-3448 anos cal AP) tenha sido coletada pelo membro da comunidade sambaquieira ou de material retrabalhado no fundo da laguna ou de depósito natural ou arqueológico preexistente (séculos mais antigo), o que, em qualquer das hipóteses, parece ser situação muito particular deste sítio. Destaque-se 
que mesmo na seção inferior do sambaqui (PX1), onde foram datadas apenas conchas, ocorrem inversões estratigráficas, reforçando a sugestão de que a utilização de material conchífero retrabalhado foi um expediente recorrente e intencional no processo de construção do sambaqui Perrixil.

Há uma clara moda de idades de conchas e carvões neste sambaqui, entre 1833 e 1373 anos cal AP. As idades que destoam desta moda, todas cerca de 500 anos mais antigas, ou estão na base da seção inferior (PX1) ou são as de conchas discrepantes com carvão ou que mostram inversão estratigráfica. Desse modo, uma hipótese plausível é a de que este sambaqui teve duas fases de construção e que a segunda fase incluiu reaproveitamento de material da primeira fase, o que ocasionou o padrão de inversões estratigráficas. Nessa linha de interpretação, não se pode descartar a hipótese de que as conchas da base da seção PX1 (2475-2303 anos cal AP) representem o remanescente in situ da primeira fase de construção.

Por que o reaproveitamento ou reciclagem de material do próprio sítio, sugerido nos resultados do Perrixil, não está evidenciado nos dez demais sítios aqui estudados? Esta questão aponta para o Perrixil como um sambaqui de processo de construção diferenciado, o que pode ser explicado num contexto cultural: este sítio destaca-se também dos demais tanto no aspecto da distribuição espacial, já que é o mais a norte dentre os sítios estudados e o único inteiramente situado na porção valelaguna do sistema lagunar, quanto no aspecto da distribuição no tempo, já que nele foram encontradas as idades mais jovens desta tese. Assim, é possível que tenha havido uma mudança no tempo, ou no espaço (do sul para o norte da área), nas estratégias de construção do depósito arqueológico.

A porção superior da seção PX1 e toda a seção PX2 enquadram-se no tipo estratigráfico 3, depósito ictiológico (Giannini et al. 2010), seja no aspecto do material construtivo, com forte presença de ossos, seja nas idades (entre 1833 e 1373 anos cal AP). A diferença está na maior presença de conchas, o que, no entanto, poderia ser explicado pela hipótese de retrabalhamento de depósito arqueológico.

Já o hiato de aproximadamente 4000 anos na seção de depósito paleolagunar JBL coincide com o contato abrupto entre fácies cascalhosas com conchas inteiras (CiqA), atribuída a deposição na zona inframaré abaixo do nível de base de onda, da época de NRM alto holocênico, e fácies de conchas quebradas ( $\mathrm{CqA})$, atribuída à deposição acima do nível de ação de ondas e correntes, de época de NRM declinante. 
É normal que a queda do espaço de acomodação na laguna, ocasionado pelo declínio do NRM, favoreça a erosão e a geração de hiatos como este.

\subsection{Sambaquis versus depósitos paleolagunares}

A maior variabilidade de seixos, areia fina e pelíticos nos sambaquis, em comparação com os depósitos de paleolagunas (Figura 57) permite interpretar que a escolha mais frequente feita no processo de construção de cada camada/fácies dos sambaquis esteja relacionada com a quantidade de conchas versus a quantidade de sedimento lagunar, este tipicamente uma areia fina a média, lamosa. Por outro lado, a proporção máxima de pelíticos nas fácies de sambaquis (cerca de 60\%) é muito mais elevada que nas paleolagunas (menos de 20\%) (Figura 57). Na improbabilidade de os construtores de sambaquis terem selecionado a fração lamosa, isto evidencia que parte significativa da lama presente nas arqueofácies deva vir não diretamente do sedimento paleolagunar, e sim de finos adicionados ao depósito seja pela ação antrópica intencional, na deposição (eg cinzas, conchas e ossos moídos) seja na eodiagênese (eg matéria orgânica e produtos de alteração química ou mecânica de cinzas, conchas moídas, ossos e carvões). A interpretação de finos eodiagenéticos é reforçada pela presença frequente, detectada no estudo ao microscópio óptico das arqueofácies, de cimento fosfático originado a partir da matéria orgânica e/ou da dissolução e reprecipitação de ossos (Figura 87), de cimento carbonático de micrita e microespato formado a partir dos fragmentos de conchas ou mesmo da alteração de cinzas (Figura 88) (Reveg et al., 2011), e de feições de esmagamento de carvões (Figura 89). 

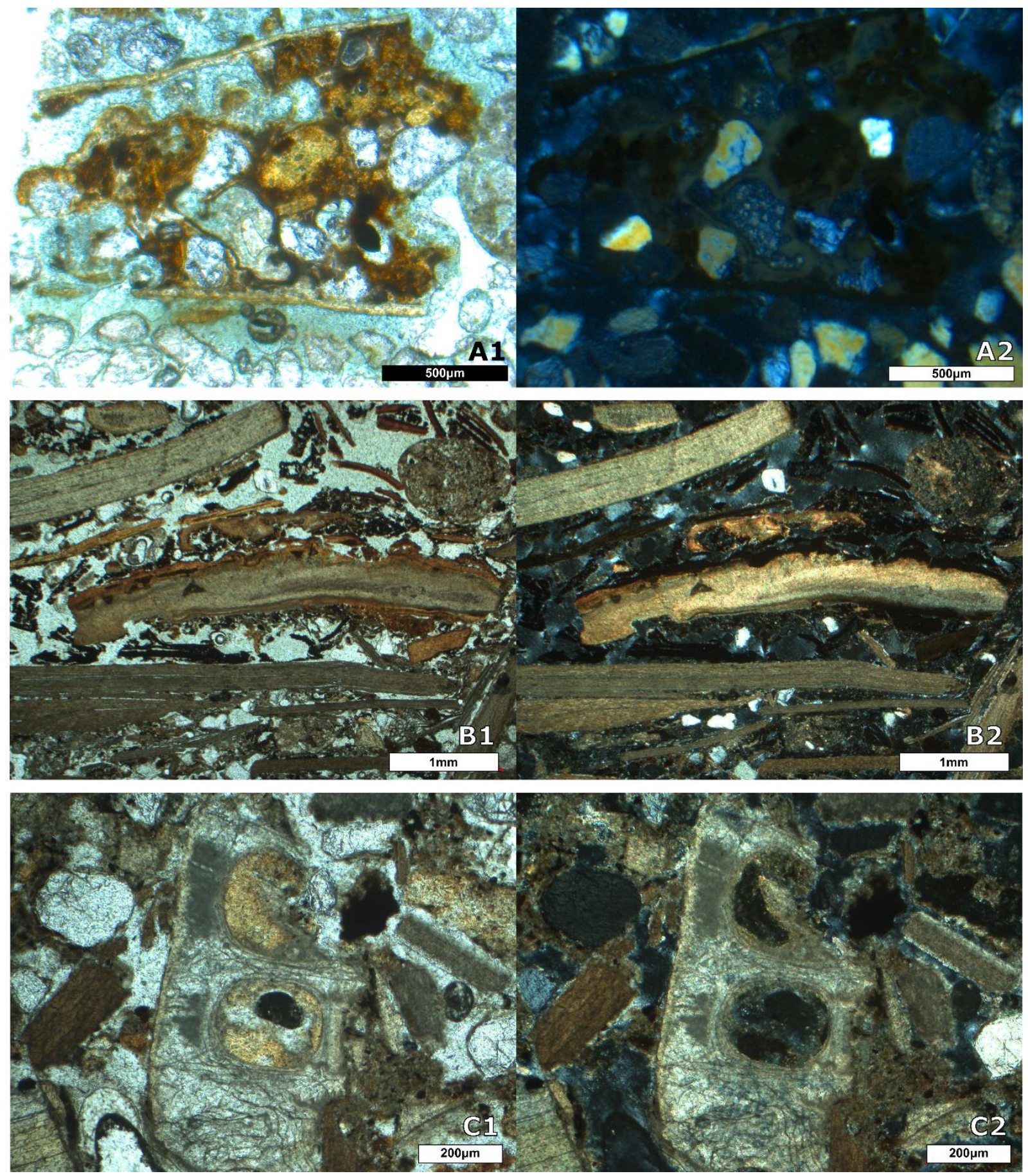

Figura 87. Cimento fosfático: A) intraclasto de cimento fosfático, restos de osso e grãos de quartzo (GS2-C3; AFS1); B) concha de molusco com revestimento cimento fosfático colofânico (JB-C1; AFS5); C) craca preenchida por cimento fosfático (JB-C1; AFS5). A1, B1 e C1: polarizadores paralelos. A2, B2 e C2: polarizadores cruzados. 

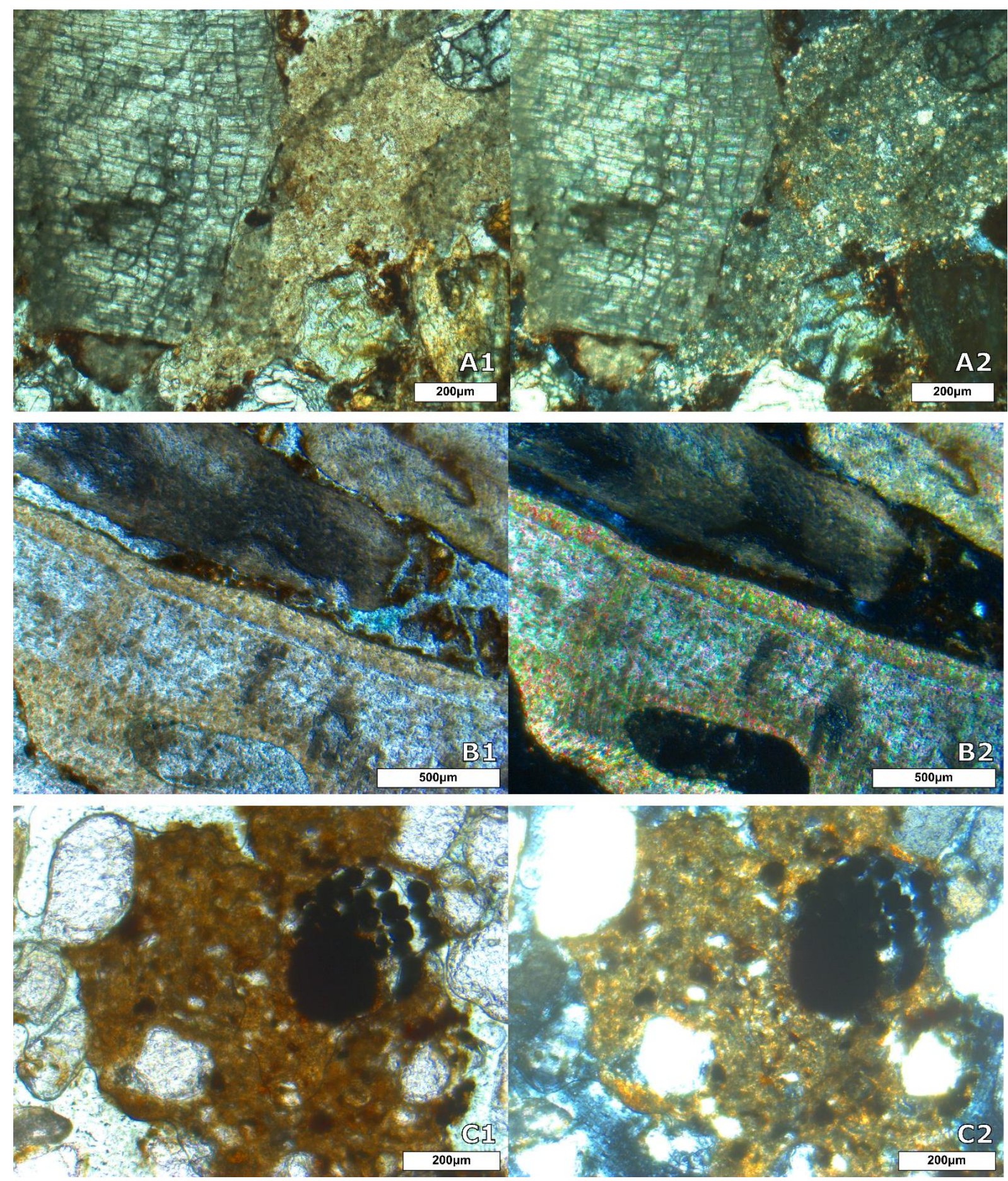

Figura 88. Cimento carbonático: A) microespato (CN3-C1; AFS7); B) película de carbonato reprecipitado em torno de bioclasto de molusco (JC-C1; AFS4); C) intraclasto de micrita mecanicamente deformado, associado a pellets (GS2-C3; AFS1). A1, B1 e C1: polarizadores paralelos. A2, B2 e C2: polarizadores cruzados. 

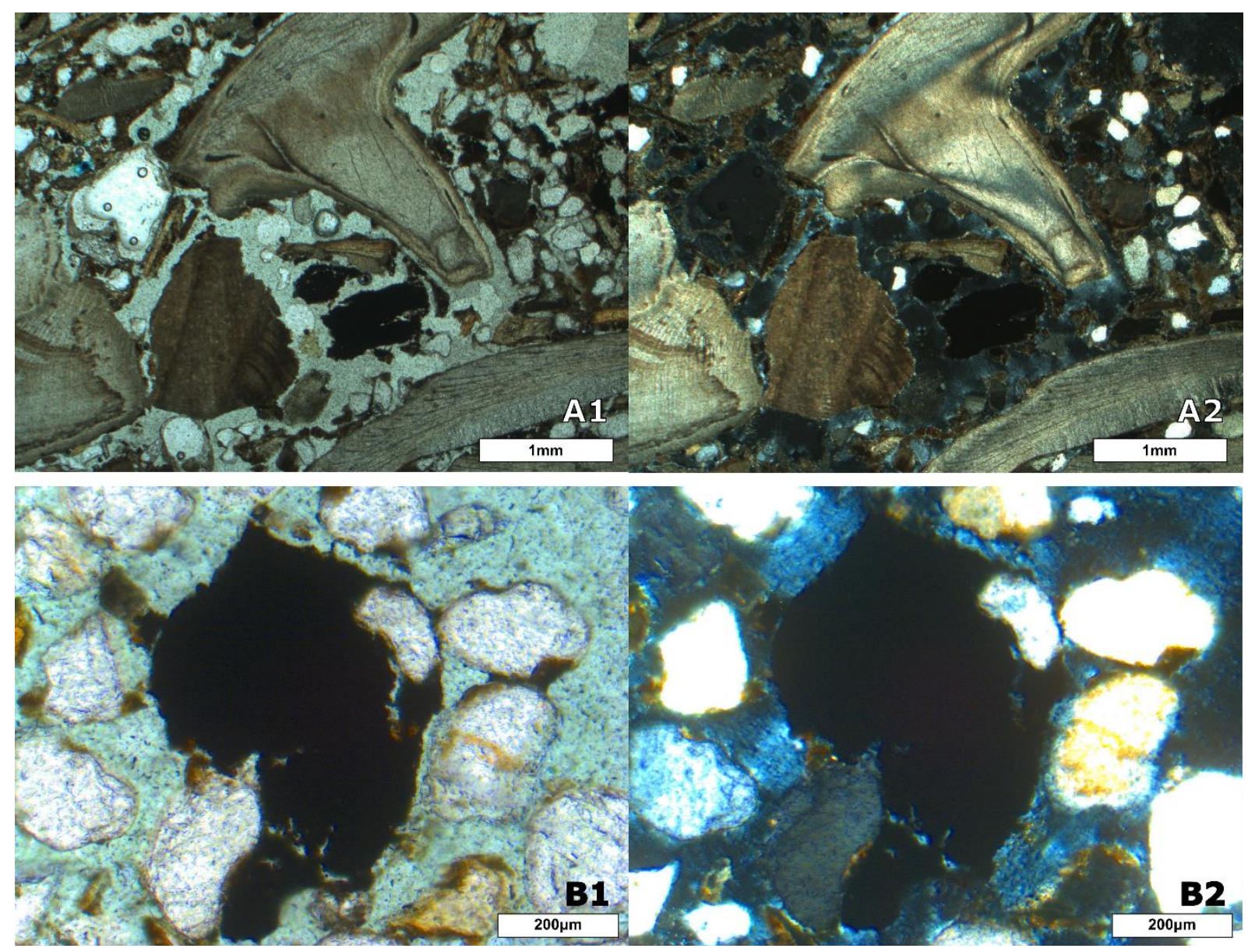

Figura 89. Fragmentos de carvão: A) carvão fragmentado (JB-C1; AFS5)em meio a fragmentos de conchas e areia terrígena; B) carvão amassado por grãos rígidos de quartzo (GS2-C3; AFS1). A1, B1: polarizadores paralelos. A2, B2: polarizadores cruzados.

As fácies analisadas de sambaquis apresentam também, em comparação com os depósitos paleolagunares, maior variabilidade de medidas estatísticas da distribuição granulométrica relativas aos três primeiros momentos (Figura 58), demonstrada nos valores mais elevados tanto de amplitude total de variação ("bigodes" dos gráficos em caixa), quanto de intervalo interquartis (a própria caixa). Esta maior variabilidade de tamanho médio, desvio padrão e assimetria reflete a maior diversidade de fácies encontrada e amostrada nos depósitos arqueológicos, em comparação com os depósitos naturais. De fato, nos sambaquis foram descritas 30 fácies diferentes, enquanto nas paleolagunas identificaram-se apenas 13, portanto menos da metade.

A tendência para sedimentos mais grossos nos sambaquis, detectada nos gráficos em caixa das estatísticas granulométricas (Figura 58) decorre do uso deliberado de conchas centimétricas, inteiras ou não, na grande maioria das fácies, provavelmente com intuito de dar volume à construção. Os valores absolutos mais 
altos de assimetria da distribuição granulométrica nos sambaquis (Figura 58) refletem, quando positivos (moda e mediana mais grossas que a média), a seleção deliberada, daqueles que construíram o sambaqui, deste material grosso, geralmente representado pelas conchas inteiras ou pouco fragmentadas; quando negativos (moda e mediana mais finas que a média), refletem o uso de areia ou areia lamosa e/ou o uso ou produção pós-deposicional de material finamente fragmentado ou moído, sejam conchas, ossos ou carvões.

Nas fácies dos depósitos paleolagunares dominadas por conchas fragmentadas, a alta proporção de conchas com sinais elevados de dissolução parece indicar que essas duas assinaturas tafonômicas, fragmentação e dissolução, estejam correlacionadas entre si. Isto se deve provavelmente ao aumento da superfície específica das conchas mais fragmentadas, e, portanto, da sua maior exposição às águas intersticiais e à dissolução.

O bivalve Anomalocardia brasiliana está presente em ambos os depósitos, paleolagunares naturais e sambaquis, e é dominante em quase todos os sítios. As exceções são os sambaquis Caipora - e o depósito paleolagunar circunvizinho, o CPL -, o Jaboticabeira 1 e o Perrixil, onde há domínio da Crassostrea brasiliana. No mesmo depósito paleolagunar Caipora, foram identificadas ainda frústulas da diatomácea Paralia sulcata (Ehrenberg) Cleve, 1873, com dimensões menores que $20 \mu \mathrm{m}$. Este táxon aparece como espécie de diatomácea dominante no testemunho raso $(2,5 \mathrm{~m})$ analisados por Amaral et al. (2012) no sistema vale-laguna a sul de Jaguaruna (Riachinho; Figura 1). Paralia sulcata já foi descrita em diversos estudos sobre diatomáceas na Região Sul do Brasil (Mosimann, 1988, Moreira Filho et al., 1985) e sua presença é comum em sedimentos de águas costeiras pouco profundas, incluindo áreas de estuários (Poulin et al. 1984; Jiang et al. 1997). Trata-se de espécie de ampla distribuição geográfica, marinha euritópica, portanto capaz de tolerar variações nas concentrações de sal na água, e de hábito de vida planctônico (Moreira Filho et al., 1985; Denys, 1994; Jiang, 1997). Em corpos de água mais abertos, como estuários e baías, a presença dessa espécie com dimensões menores que $20 \mu \mathrm{m}$ reflete, de acordo com McQuoid e Nordberg (2003), colunas de água com grande mistura vertical, por exemplo em condições de ressurgência para a superfície de águas ricamente nutritivas e de salinidade mais alta. 


\subsection{Associações de fácies}

A análise de fácies nas diferentes seções verticais permitiu identificar sucessões preferenciais ou padrões recorrentes de empilhamento, mais evidentes nos depósitos de paleolagunas e paleobaías, cujas fácies são menos diversificadas, mas presentes também nos sambaquis. A identificação destes padrões de empilhamento foi o ponto de partida para o reconhecimento de associações de fácies, formadas por fácies de constituição ou trama similar e que se intercalam ou se substituem umas às outras, nas sucessões verticais.

Os agrupamentos de fácies de sambaquis visaram antes detectar materiais em comum, e, possivelmente fontes em comum, entre elas, que discutir processos formativos em comum, o que não é o foco desta tese. Analogamente, eventuais comparações entre associações de fácies lagunares e associações de fácies de sambaquis são feitas apenas para destacar disponibilidade de material construtivo (principalmente as próprias conchas) no fundo paleolagunar contemporâneo ao sambaqui.

\subsubsection{Associações de fácies lagunares}

Cada uma das seções verticais de até pouco mais de $1 \mathrm{~m}$ estudadas nos depósitos paleolagunares é geralmente composta por não mais que três fácies, cujas variações laterais resultam, porém, em um número maior de associações, codificadas AFL1 a AFL5, na ordem provável da base para o topo (Tabela 8). 
Tabela 8. Associações de fácies dos depósitos paleolagunares.

\begin{tabular}{|c|c|c|c|}
\hline $\begin{array}{c}\text { Associação de fácies lagunar } \\
\text { (AFL) }\end{array}$ & $\begin{array}{l}\text { Fácies } \\
\text { constituintes }\end{array}$ & $\begin{array}{l}\text { Depósito } \\
\text { paleolagunar }\end{array}$ & $\begin{array}{l}\text { Idades de concha } \\
\text { (anos cal AP) }\end{array}$ \\
\hline $\begin{array}{c}\text { AFL1 } \\
\text { Cascalho clasto-suportado com } \\
\text { conchas dominantemente inteiras }\end{array}$ & CiqA & $\mathrm{JBL}$ & $\begin{array}{l}6841-7085 \\
6705-6932\end{array}$ \\
\hline \multirow{2}{*}{$\begin{array}{c}\text { AFL2 } \\
\text { Lama arenosa ou areia média com } \\
\text { conchas inteiras, frequentemente } \\
\text { em posição de vida }\end{array}$} & ACpv & GSL & \\
\hline & LACpv & CPL2 & $5660-5880$ \\
\hline \multirow{3}{*}{$\begin{array}{c}\text { AFL3 } \\
\text { Cascalho clasto-suportado com } \\
\text { conchas inteiras e quebradas }\end{array}$} & Ciqg & $\mathrm{CNL}$ & $1970-2171$ \\
\hline & CiALmo & PXL & $2762-2946$ \\
\hline & CiqA & JBL & 2884-2706 \\
\hline \multirow{4}{*}{$\begin{array}{l}\text { AFL4 } \\
\text { Areia com cascalho conchífero } \\
\text { dominantemente fragmentado }\end{array}$} & CqALmo & PXL & \\
\hline & \multirow{2}{*}{$\mathrm{CqA}$} & GSL & \\
\hline & & $\mathrm{JBL}$ & 2318-2537 \\
\hline & $\mathrm{Cq}$ & CPL1 & $5036-5269$ \\
\hline \multirow{6}{*}{$\begin{array}{c}\text { AFL5 } \\
\text { Lama arenosa, areia lamosa ou } \\
\text { areia, turfosa, com conchas raras a } \\
\text { ausentes }\end{array}$} & LAmoCiq & CNL & \\
\hline & \multirow{3}{*}{ ALmo } & PXL & \\
\hline & & GSL & \\
\hline & & $\mathrm{JBL}$ & \\
\hline & \multirow{2}{*}{ A } & GSL & \\
\hline & & $\mathrm{JBL}$ & \\
\hline
\end{tabular}

A AFL1 é representada por cascalho clasto-suportado com conchas dominantemente inteiras, inclusive articuladas, o que sugere proximidade em relação aos bancos sedimentares com moluscos in situ, porém com algum retrabalhamento de fundo suficiente, para lavar a matriz areno-lamosa. A concentração elevada de conchas inteiras caoticamente orientadas, com pouca ou nenhuma matriz arenosa associada, indica formação como depósito residual (lag), sob ação de ondas ou correntes no interior da baía ou laguna. Duas datações na paleolaguna Garopaba do Sul, próximo aos sambaquis Jaboticabeira, deram idades similares entre si, dentro do intervalo entre 7085 e 6705 anos cal AP, mais de 1000 anos anteriores ao admitido para o máximo NRM na região (Angulo et al. 1999, 2006; Toniolo, 2014, 2017). Nessa época, é possível que a transgressão holocênica permanecesse em andamento na área e, até mesmo, que a barreira arenosa a sul do cabo de Santa Marta ainda não existisse (Giannini 2002, Giannini et al. 2010, Amaral et al. 2012, Fornari et al. 2012). Deste modo, a área amostrada situava-se no interior de uma grande baía semiaberta, portanto mais sujeita à ação de ondulações, as quais, porém perderiam força baía adentro, o que favoreceria a formação de lags conchíferos ricos em espécimes inteiros 
e articulados. É provável, também, que estes lags tenham-se espalhado progressivamente rumo ao interior da paleobaía à medida que a linha de costa migrava para o continente. Nesse sentido, a AFL1 guarda correlação, tanto genética quanto estratigráfica e cronológica, com os lençóis de areia transgressivos identificados na porção retrobarreira da baía-laguna por Fornari et al. (2012) (item 2.3.4). As diferenças residem na granulometria, já que os depósitos descritos por aqueles autores são dominados por areia, e não por cascalho como aqui, e no maior grau de fragmentação das conchas dos lençóis. A interpretação mais provável é que os cascalhos clasto-suportados de AFL1 ocorram em meio aos lençóis de areia transgressivos, demarcando episódios de ação de ondas ou correntes mais fortes, durante a transgressão, que denudariam o fundo da baía, até a zona de enterramento dos moluscos; estes teriam então suas valvas expostas, e subsequentemente concentradas por elutriação natural.

A AFL2 corresponde a lama arenosa a areia média com conchas de bivalves inteiras (Figura 90), frequentemente articuladas e em posição de vida. Uma única datação foi feita nesta associação, em espécime de $A$. brasiliana coletado no terreno de paleobaía adjacente ao sambaqui Caipora (CPL2), obtendo-se idade de 5880-5660 a cal AP, próxima ao admitido para o pico de NRM nesta região (Angulo et al., 1999, 2006). No entanto, datações realizadas previamente nesta mesma associação de fácies por Giannini et al. (em preparo), em diferentes espécies de bivalve articulado in situ da paleolaguna Garopaba do Sul, já haviam fornecido idades próximas, variando de 5280 a 4350 anos cal AP (Tabela 9).

Tabela 9. Idades ${ }^{14} \mathrm{C}$ AMS obtidas para amostras de concha de moluscos de lama arenosa a areia lamosa preta, incluindo bivalves em posição de vida $\left(^{*}\right)$, da paleolaguna Garopaba do Sul, próximo ao sambaqui homônimo. Depósitos correlatos a AFL2. Dados de Giannini et al. (em preparo).

\begin{tabular}{|c|c|c|c|c|}
\hline Amostra & Espécie datada & $\begin{array}{c}{ }^{13} \mathbf{C} /{ }^{12} \mathbf{C} \\
\mathbf{( \% / 0 0 )}\end{array}$ & $\begin{array}{c}\text { Idade }{ }^{14} \mathbf{C} \\
\text { calibrada } \\
\text { (anos AP) }\end{array}$ & $\begin{array}{c}\text { № de referência } \\
\text { do laboratório }\end{array}$ \\
\hline GS15 & Lucina sp. ${ }^{*}$ & $+3,2$ & $4650-4350$ & Beta 209717 \\
\hline GS16 & Anomalocardia brasiliana $^{*}$ & $+0,6$ & $5260-4850$ & Beta 209718 \\
\hline GS17 & Tagelus sp. $^{*}$ & $+1,8$ & $5280-4820$ & Beta 209719 \\
\hline GS18 & Thais haemastoma $^{\mid r}$ & $+1,3$ & $5390-5230$ & Beta 209720 \\
\hline
\end{tabular}



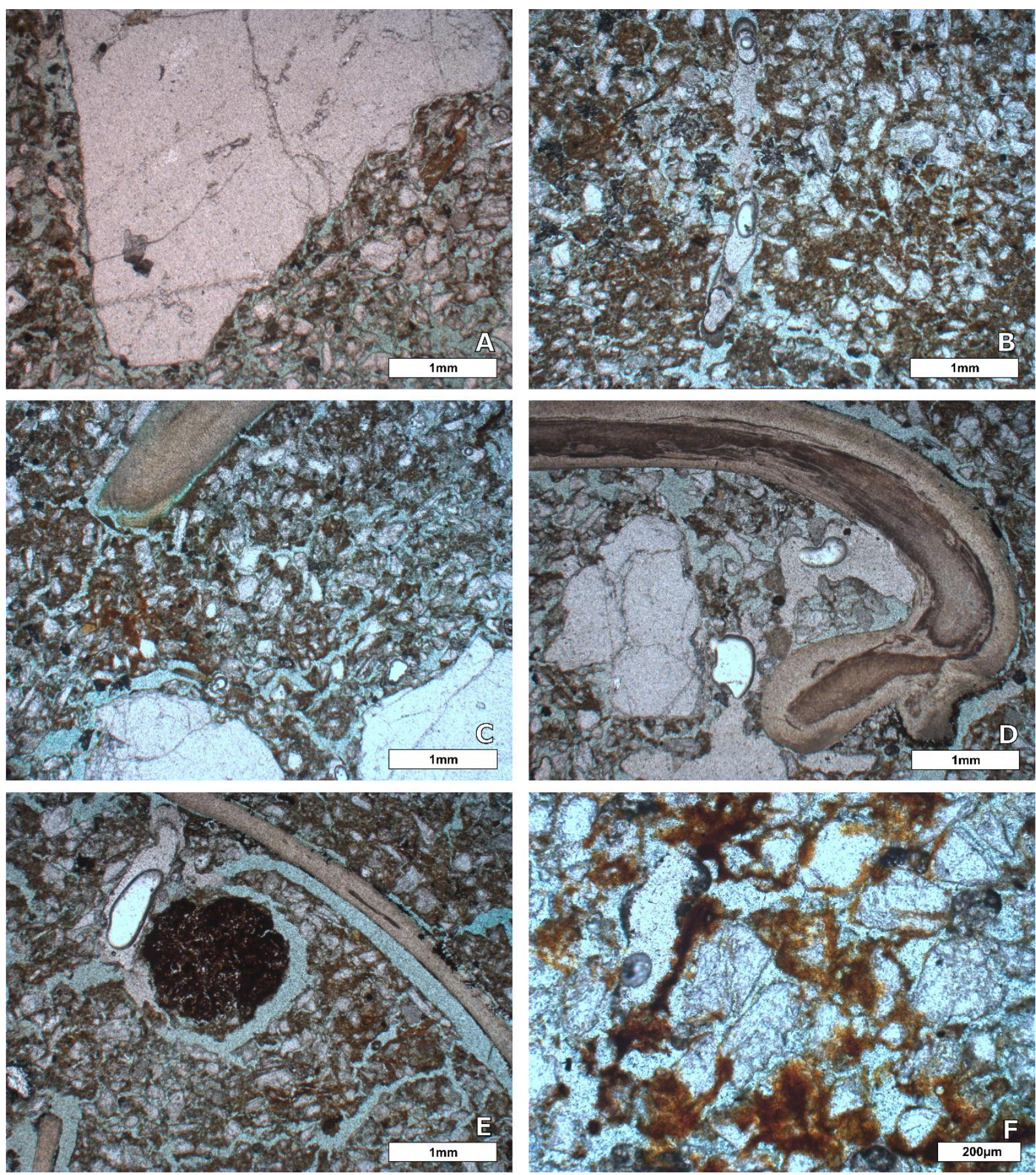

Figura 90. Fotomicrografias, a polarizadores paralelos, do depósito paleolagunar CPL2-C1 pertencente a AFL2: A. seixo anguloso de quartzo em meio a areia média a muito fina, com pouca protomatriz lamosa; B. possível bioturbação; C. areia e seixos de quartzo e bioclasto carbonático; D. bioclasto de bivalve; E. intraclasto de lama orgânica; F. detalhe do cimento argilo-orgânicoferruginoso

Características da AFL2, tais como a frequente presença de lama associada à matéria orgânica coloidal e a abundância de bivalves articulados em posição de vida apontam para deposição em condições hidrodinâmicas calmas na zona inframaré, portanto abaixo do nível de base de ação das ondas lagunares e fora do alcance de correntes de maré fortes. A época do máximo NRM, quando esta associação foi 
formada, é a que, devido à elevação da lâmina de água, favorece o surgimento destas condições em mais ampla área do sistema paleolagunar. A AFL2 correlaciona-se estratigraficamente com a segunda associação de fácies, lagunar, identificada por Fornari et al. (2012) nos depósitos retrobarreira da baía-laguna. A principal diferença reside nas idades mínimas, já que na base de dados daqueles autores esta associação alcança idades tão jovens quanto 2500 anos AP. Esta diferença é atribuída aqui apenas a uma questão de amostragem limitada (nesta tese), já que é esperado que as condições de inframaré de baixa energia na laguna, evocadas para a formação desta fácies, continuem a existir, ainda que menos amplamente, mesmo depois da época da máxima inundação e/ou do máximo nível do mar.

A AFL3 reúne três fácies que têm em comum a presença de cascalho clastosuportado com conchas inteiras e quebradas (Figura 91). Três datações, obtidas em cada uma destas fácies, resultaram em idades entre 2884 e 1970 anos cal AP, época de NRM suavemente declinante em escala milenar (Angulo et al. 1999, 2006; Toniolo, 2014, 2017). A granulação grossa do depósito e o estado de fragmentação parcial das conchas aponta para hidrodinâmica intensa e recorrente, compatível com deposição abaixo do nível de base de ação das ondas lagunares e/ou ao alcance de correntes de maré, nas zonas inframaré e intermarés.

A AFL4 agrupa três fácies em que se destaca a presença dominante de areia, com cascalho conchífero dominantemente fragmentado (Figura 92). A deposição desta associação faciológica é atribuída à ação frequente de ondas lagunares e correntes de maré fracas, característica da zona intermarés. Datações em raros espécimes de conchas inteiras e não desgastadas forneceram idades de 5269-5036 anos cal AP, na paleobaía adjacente ao sambaqui Caipora, e de 2537-2318 anos cal AP, na paleolaguna Garopaba do Sul, junto aos sambaquis Jaboticabeira. Partindose da premissa de que as conchas datadas são de moluscos contemporâneos à sedimentação, a idade mais antiga dos depósitos da mesma associação na porção mais interior do sistema lagunar deve-se ao fato de que a associação de fácies cruza as linhas de tempo, isto é, neste caso específico, a linha de costa lagunar deslocouse no decorrer do tempo, em contexto regressivo e portanto de sucessivo raseamento, o que fez com que as condições de intermarés favoráveis a esta associação de fácies fossem precocemente alcançadas na porção mais continental (e rasa) do sistema. 

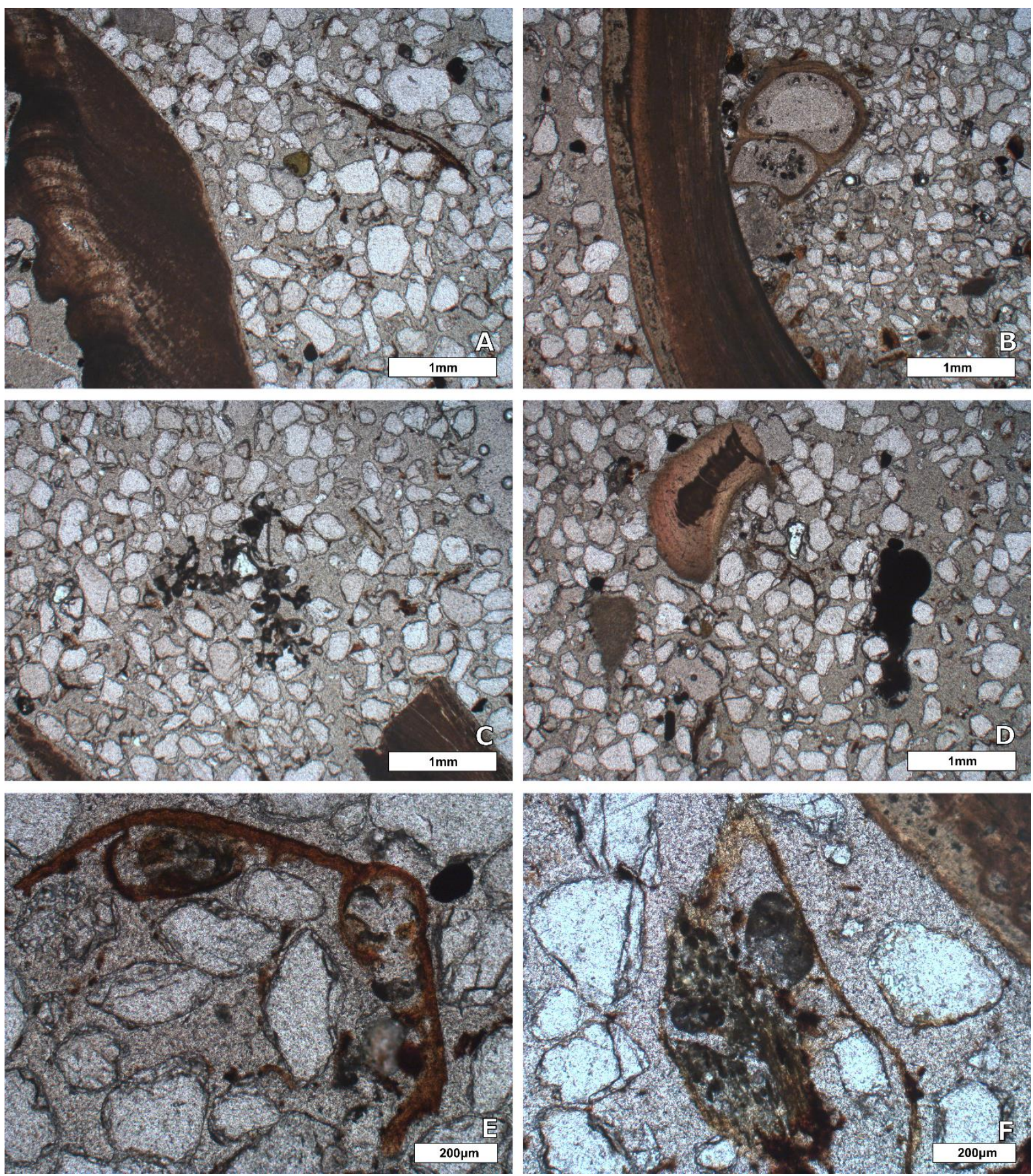

Figura 91. Fotomicrografias a polarizadores paralelos do depósito paleolagunar PXL-C1 pertencente a AFL3. Notar: bioclastos rudáceos de bivalves (A, B); grão de gastrópode na granulação areia muito grossa (B); possíveis vestígios de carvão (C, D); bioclasto de osso (E); túnel de bioturbação, com pellets $(\mathrm{F})$; Notar ainda, em todas as imagens, a presença de areia quartzosa fina a média, bem selecionada. 

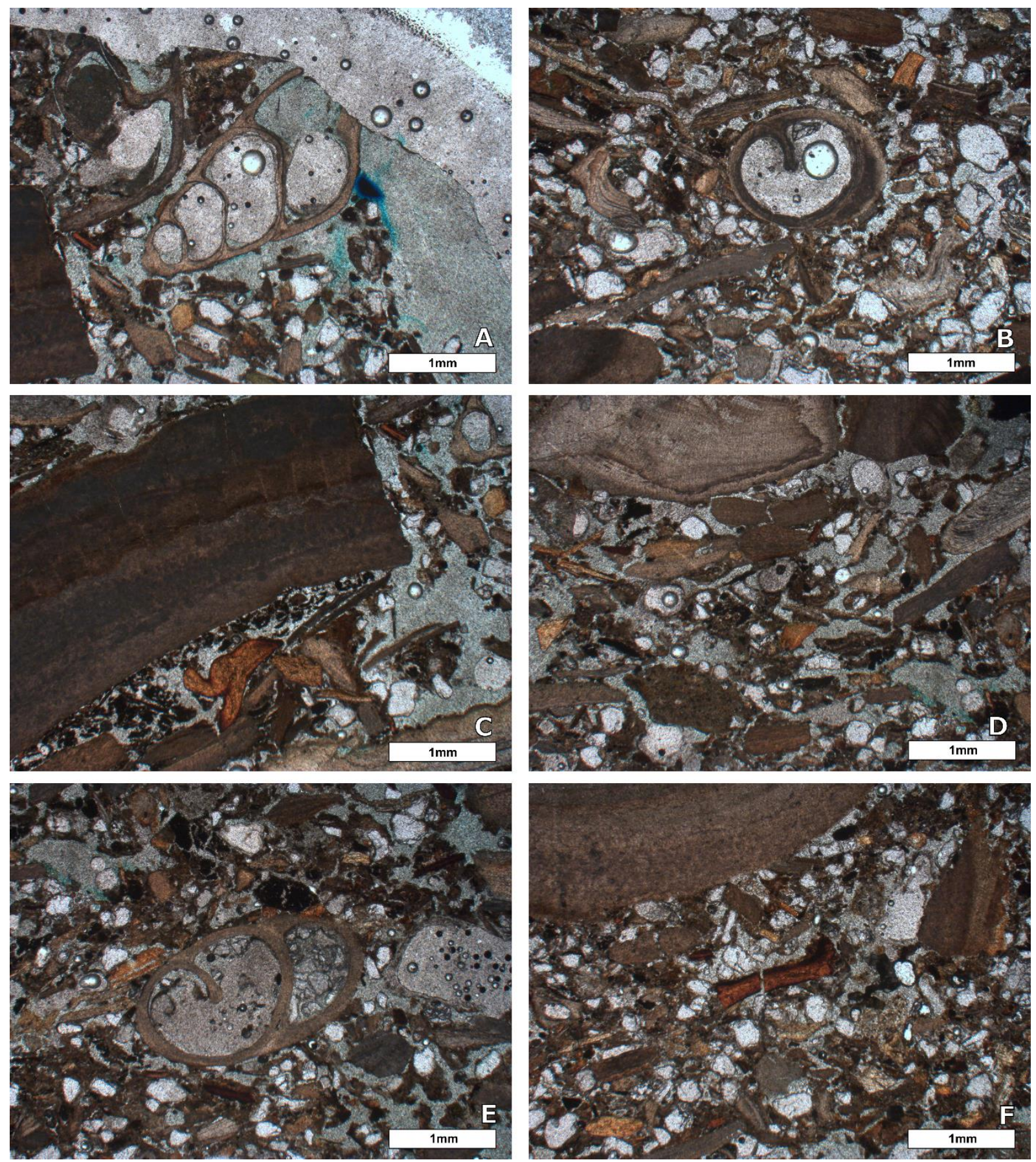

Figura 92. Fotomicrografias a polarizadores paralelos do depósito paleolagunar JBL-C2 pertencente a AFL4. Notar: bioclastos de gastrópode em meio a areia mista, terrígeno-bioclástica (A, B, E); C. bioclastos de bivalves imbricados, com fragmentos de ossos esparsos (C, D, E, F).

A associação de fácies que fecha a sucessão paleolagunar, AFL5, corresponde a lama arenosa a areia turfosa, na qual as conchas são muito raras a ausentes. Esta associação é atribuída à instalação dos brejos lagunares de supramaré, dominados por ervas e gramíneas, que hoje se veem nos locais onde foram abertas as trincheiras. Sua representatividade em área cresce, portanto, à medida que o sistema lagunar é progressivamente assoreado. Nas porções mais internas e assoreadas do sistema 
lagunar (e.g. paleobaía de Caipora), esta associação pode incluir ainda, no topo, depósitos de pântanos de água doce, formados em sucessão aos brejos de supramaré. A AFL5 correlaciona-se estratigraficamente com a terceira e mais nova associação de fácies identificada por Fornari et al. (2012) na retrobarreira da baíalaguna, cujas idades, segundo os autores, são inferiores a cerca de 2500 anos AP.

Se a AFL1 pode ser considerada parte do registro da fase transgressiva do sistema paleolagunar, a sucessão que se segue a ela, de AFL2 a AFL5, é claramente regressiva, já que passa de depósitos de inframaré abaixo do nível de base de onda, cuja formação e preservação foi mais amplamente favorecida na época de máximo NRM (AFL2), para depósitos cascalhosos de inframaré acima do nível de base de onda (AFL3), depósitos arenosos de intermarés (AFL4) e, finalmente, areias e lamas turfosas de supramaré (AFL5).

\subsubsection{Associações de fácies de sambaquis}

Nos depósitos sedimentares de sambaquis, o estudo das associações de fácies foi feito em duas etapas, ou seja, em duas escalas de abrangência de agrupamento. $\mathrm{Na}$ primeira etapa, as fácies foram reunidas apenas por critérios de semelhança de trama e constituição e/ou por relação espacial, por exemplo ocorrência alternada nas seções estudadas, e em seguida, ordenadas e numeradas por critério misto de constituição (domínio de conchas inteiras versus domínio de bioclastos moídos) e de idade. Na segunda etapa, as associações de fácies assim obtidas (Tabela 3) foram aglutinadas em grupos maiores (i.e. conjuntos de associações de fácies) (Tabela 4), agora com significado cronológico mais evidente. Em ambas as etapas, atentou-se para a distribuição das idades das associações de fácies, incluindo o levantamento do número de ocorrências (resultados de datação) em intervalos de classes de mil anos.

\section{Primeira etapa de agrupamento}

Oito associações de fácies foram reconhecidas nos sambaquis (Tabela 10), sendo quadro marcadas pela presença de conchas dominantemente inteiras (AFS1 a AFS4) e outras quatro pela existência de conchas ou ossos quebrados ou moídos (AFS5 a AFS8). Na maioria dos casos, as fácies das associações AFS1 a AFS4 concentram-se estratigraficamente abaixo das fácies de AFS5 a AFS8. Dentro de 
cada um destes dois grupos de fácies, a numeração adotada, de 1 a 4 e de 5 a 8 , seguiu a ordem de idade máxima decrescente.

Tabela 10. Associações de fácies de sambaquis.

\begin{tabular}{|c|c|c|c|c|}
\hline $\begin{array}{l}\text { Associação de fácies } \\
\text { de sambaqui }\end{array}$ & $\begin{array}{c}\text { Fácies } \\
\text { constituintes }\end{array}$ & Sambaquis & $\begin{array}{c}\text { Idades de } \\
\text { concha } \\
\text { (anos cal AP) }\end{array}$ & $\begin{array}{c}\text { Idades de } \\
\text { carvão } \\
\text { (anos cal AP) }\end{array}$ \\
\hline \multirow{7}{*}{$\begin{array}{c}\text { AFS1 } \\
\text { Cascalho clasto- } \\
\text { suportado de conchas } \\
\text { dominantemente } \\
\text { inteiras, com eventual } \\
\text { matriz arenosa }\end{array}$} & AAC & Caipora & $\begin{array}{l}6275-6452 \\
6300-6513 \\
6156-6331\end{array}$ & \\
\hline & \multirow[t]{2}{*}{ CiA } & $\begin{array}{c}\text { Santa Marta } \\
2\end{array}$ & $\begin{array}{l}4265-4499 \\
4301-4524 \\
4347-4559 \\
4224-4449 \\
4309-4532 \\
3174-3356 \\
3090-3322 \\
\end{array}$ & $\begin{array}{l}4409-4584 \\
4246-4447\end{array}$ \\
\hline & & $\begin{array}{c}\text { Garopaba do } \\
\text { Sul (GS2) }\end{array}$ & $2822-3032$ & $2751-2861$ \\
\hline & $\mathrm{Ci}$ & $\begin{array}{l}\text { Garopaba do } \\
\text { Sul (GS1) }\end{array}$ & $\begin{array}{l}1972-2181 \\
2088-2292 \\
1952-2140 \\
1989-2215 \\
\end{array}$ & $2042-2208$ \\
\hline & \multirow{2}{*}{$\mathrm{CA}$} & $\begin{array}{c}\text { Cabeçuda } \\
\text { (CB2) }\end{array}$ & $\begin{array}{l}3927-4143 \\
3704-3941 \\
3929-4144 \\
3734-3971 \\
3810-4042 \\
\end{array}$ & $\begin{array}{l}4066-4244 \\
3859-4087\end{array}$ \\
\hline & & $\begin{array}{c}\text { Cabeçuda } \\
\text { (CB1) }\end{array}$ & $\begin{array}{l}4041-4299 \\
4069-4320 \\
3641-3860 \\
3589-3813 \\
2016-2261 \\
\end{array}$ & \\
\hline & CAmo & Carniça 3 & 3683-3403* & \\
\hline \multirow{3}{*}{$\begin{array}{c}\text { AFS2 } \\
\text { Cascalho clasto- } \\
\text { suportado por ostras } \\
\text { inteiras em matriz de } \\
\text { concha moída }\end{array}$} & Cqmo & Caipora & $\begin{array}{l}5911-6146 \\
5573-5749 \\
5588-5810\end{array}$ & \\
\hline & CotAmo & Caipora & $5835-6020$ & \\
\hline & CotALmo & $\begin{array}{c}\text { Jaboticabeira } \\
1\end{array}$ & & \\
\hline \multirow{5}{*}{$\begin{array}{c}\text { AFS3 } \\
\text { Cascalho de conchas } \\
\text { dominantemente } \\
\text { inteiras, suportado pela } \\
\text { matriz arenosa }\end{array}$} & \multirow{2}{*}{ ACiq } & $\begin{array}{c}\text { Santa Marta } \\
2 \\
\end{array}$ & $3632-3849$ & \\
\hline & & $\begin{array}{c}\text { Cabeçuda } \\
\text { (CB1) }\end{array}$ & $4077-4351$ & \\
\hline & \multirow{2}{*}{$A C$} & $\begin{array}{c}\text { Cabeçuda } \\
\text { (CB2) }\end{array}$ & $3830-4043$ & \\
\hline & & $\begin{array}{c}\text { Garopaba do } \\
\text { Sul (GS2) }\end{array}$ & $\begin{array}{l}2846-3053 \\
2853-3063 \\
\end{array}$ & \\
\hline & LAmoCiq & $\begin{array}{c}\text { Garopaba do } \\
\text { Sul (GS1) }\end{array}$ & & \\
\hline $\begin{array}{c}\text { AFS4 } \\
\text { Cascalho clasto- } \\
\text { suportado de conchas } \\
\text { dominantemente }\end{array}$ & CiALmo & $\begin{array}{c}\text { Jaboticabeira } \\
1\end{array}$ & $\begin{array}{l}3647-3867 \\
3137-3344 \\
3228-3429 \\
2309-2496 \\
\end{array}$ & $2309-2496$ \\
\hline
\end{tabular}




\begin{tabular}{|c|c|c|c|c|}
\hline $\begin{array}{l}\text { Associação de fácies } \\
\text { de sambaqui }\end{array}$ & $\begin{array}{c}\text { Fácies } \\
\text { constituintes }\end{array}$ & Sambaquis & $\begin{array}{c}\text { Idades de } \\
\text { concha } \\
\text { (anos cal AP) }\end{array}$ & $\begin{array}{c}\text { Idades de } \\
\text { carvão } \\
\text { (anos cal AP) }\end{array}$ \\
\hline \multirow{5}{*}{$\begin{array}{l}\text { inteiras, com matriz } \\
\text { lamosa }\end{array}$} & CiAmo & Perrixil (PX1) & $2303-2475$ & \\
\hline & \multirow[b]{2}{*}{ CLAmo } & $\begin{array}{c}\text { Carniça } 1 \\
\text { (CN2) }\end{array}$ & & \\
\hline & & $\begin{array}{l}\text { Carniça } 1 \\
\text { (CN3) }\end{array}$ & $2249-2466$ & \\
\hline & \multirow{2}{*}{ Cmo } & $\begin{array}{c}\text { Carniça } 1 \\
\text { (CN2) }\end{array}$ & $\begin{array}{l}2366-2651 \\
2318-2537 \\
2306-2535\end{array}$ & \\
\hline & & $\begin{array}{c}\text { Carniça } 1 \\
\text { (CN3) }\end{array}$ & & \\
\hline \multirow{3}{*}{$\begin{array}{c}\text { AFS5 } \\
\text { Cascalho conchífero de } \\
\text { conchas } \\
\text { dominantemente } \\
\text { quebradas }\end{array}$} & $\mathrm{CqA}$ & $\begin{array}{l}\text { Santa Marta } \\
\text { (SM) }\end{array}$ & & \\
\hline & \multirow[b]{2}{*}{ CiqLmo } & Caipora & $5589-5800$ & \\
\hline & & $\begin{array}{c}\text { Jaboticabeira } \\
2\end{array}$ & $\begin{array}{l}2350-2497 \\
1830-2012 \\
1858-2044\end{array}$ & $2343-2504$ \\
\hline \multirow{7}{*}{$\begin{array}{c}\text { AFS6 } \\
\text { Cascalho conchífero } \\
\text { fino, clasto-suportado, } \\
\text { em matriz de conchas } \\
\text { moídas }\end{array}$} & \multirow{2}{*}{ CAcm } & $\begin{array}{c}\text { Jaboticabeira } \\
1\end{array}$ & 2044-2276 & \\
\hline & & $\begin{array}{l}\text { Garopaba do } \\
\text { Sul (GS2) }\end{array}$ & & \\
\hline & $\mathrm{AcmC}$ & $\begin{array}{l}\text { Garopaba do } \\
\text { Sul (GS2) }\end{array}$ & 2794-3023 & \\
\hline & \multirow[t]{2}{*}{$\mathrm{Ccm}$} & $\begin{array}{c}\text { Jaboticabeira } \\
2 \\
\end{array}$ & $1789-1966$ & \\
\hline & & Perrixil (PX1) & $2402-2675$ & \\
\hline & CcmLmo & Perrixil (PX1) & $1423-1628$ & \\
\hline & CabAcm & Perrixil (PX2) & $\begin{array}{l}1531-1704 \\
1540-1724 \\
1373-1542 \\
\end{array}$ & \\
\hline \multirow{4}{*}{$\begin{array}{c}\text { AFS7 } \\
\text { Cascalho conchífero } \\
\text { em matriz de ossos } \\
\text { moídos }\end{array}$} & \multirow{2}{*}{ CAfo } & $\begin{array}{c}\text { Carniça } 1 \\
\text { (CN2) }\end{array}$ & & \\
\hline & & $\begin{array}{l}\text { Carniça } 1 \\
\text { (CN3) }\end{array}$ & $\begin{array}{l}2306-2481 \\
2294-2459\end{array}$ & \\
\hline & Cio & $\begin{array}{c}\text { Carniça } 1 \\
\text { (CN3) }\end{array}$ & $2307-2488$ & \\
\hline & $\begin{array}{l}\text { CotAfo- } \\
\text { CotAcm }\end{array}$ & Perrixil (PX2) & & $\begin{array}{l}1701-1833 \\
1588-1747 \\
1610-1752 \\
1542-1633 \\
\end{array}$ \\
\hline $\begin{array}{c}\text { AFS8 } \\
\text { Areia lamosa em matriz } \\
\text { de ossos moídos }\end{array}$ & Alfo & $\begin{array}{c}\text { Jaboticabeira } \\
2\end{array}$ & $\begin{array}{l}1737-1925 \\
1803-1975 \\
1820-1994 \\
\end{array}$ & \\
\hline
\end{tabular}

A AFS1 é formada por cinco fácies, descritas em cinco sambaquis (Tabela 3). Estas fácies têm como principal traço em comum a sustentação por cascalho de conchas de $A$. brasiliana dominantemente inteiras, puras ou com matriz arenosa. As 32 idades ${ }^{14} \mathrm{C}$ obtidas nesta associação (seis em carvão e 26 em conchas) variam de 
6513 a 1952 anos cal AP, com moda no intervalo de 5000 a 3000 anos cal AP, onde se concentram $63 \%$ dos resultados de datação. A matriz de areia fina a média contém peloides intraclásticos de calcimicrita e de fosfamicrita, grãos de carvão amassado e sinais de bioturbação, inclusive concentrações de pellets (Figura 93).
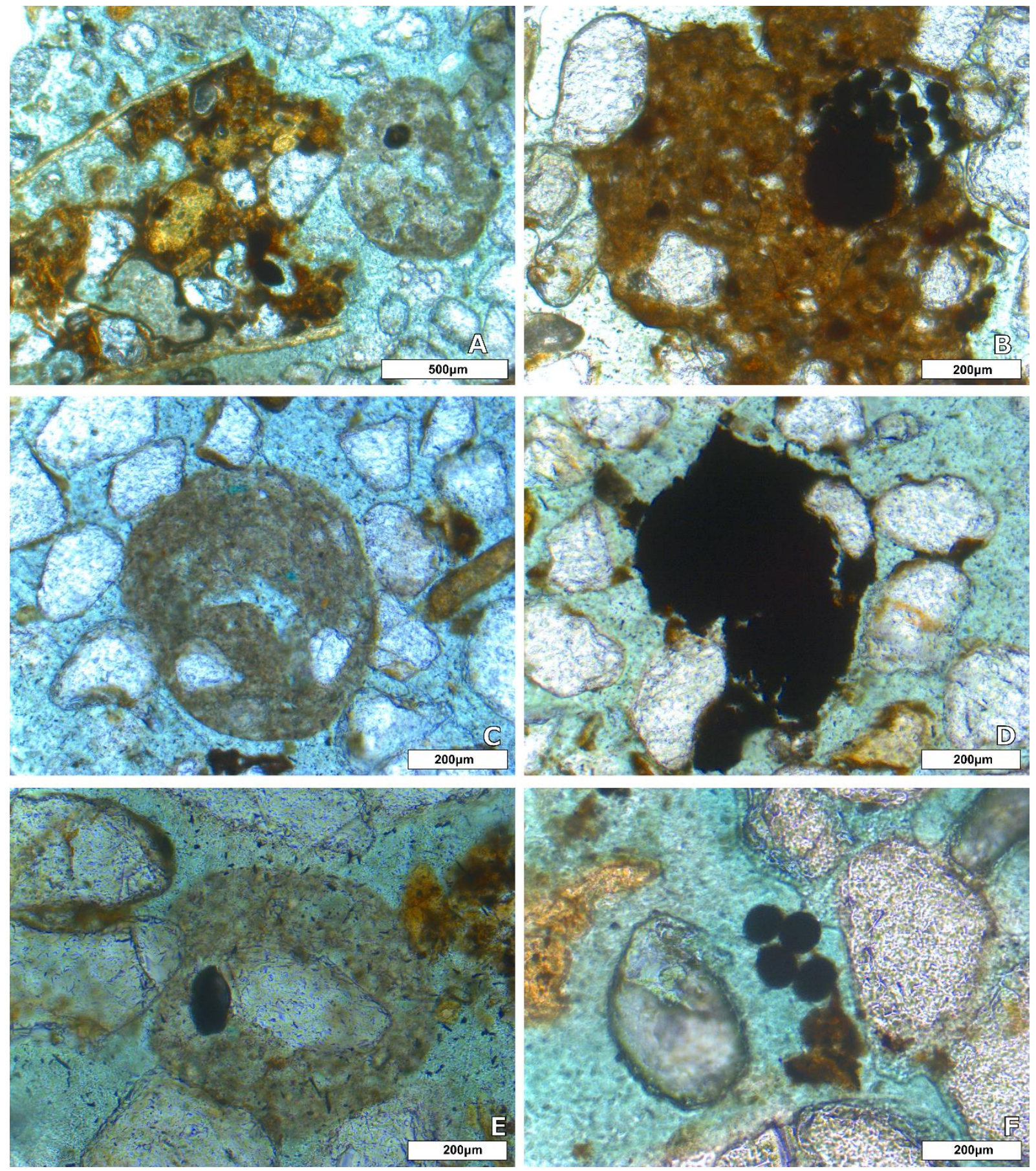

Figura 93. Fotomicrografias a polarizadores paralelos de detalhes da matriz arenosa da camada 3 do sambaqui Garopaba do Sul (GS2-C3), pertencente a AFS1: A. intraclastos de matriz foasfamicrítica (grão amarelo, à esquerda) e calcimicrítica; B. intraclasto amassado de calcifosfamicrita, com túnel de bioturbação preenchido por pellets; C. peloide intraclástico de calcimicrita; D. fragmento de carvão mecanicamente deformado; E. peloide de calcimicrita; F. pellets em porosidade intergranular. 
A AFS2 é formada por três fácies, caracterizadas pela presença de cascalho clasto-suportado por ostras inteiras em matriz de concha moída (Tabela 3). Ela foi observada em apenas dois sambaquis, Caipora e Jabuticabeira 1. As quatro idades obtidas em conchas variam de 6146 a 5573 anos cal AP, estando a moda principal (67\% das idades computadas) no intervalo de 6000 a 5000 anos AP. Ao microscópio, a matriz mostra também presença de ossos, inclusive queimados (Figura 94).
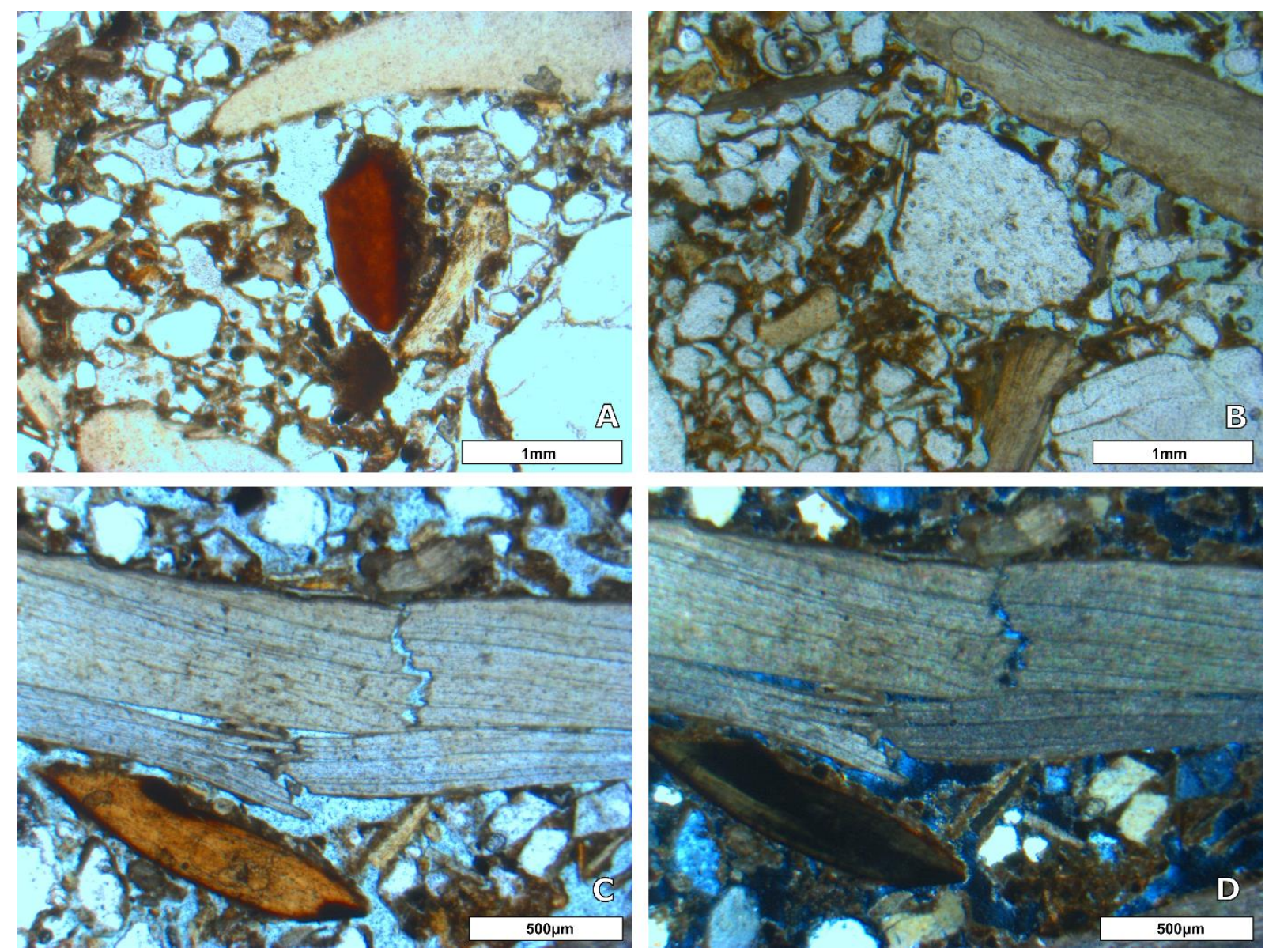

Figura 94. Fotomicrografias da camada 4 do sambaqui Caipora (CP-C4) pertencente a AFS2: A.

bioclastos de conchas e osso queimado, em meio a areia fina a média; B. grãos terrígenos e fragmentos de conchas e ossos; notar amassamento da concha no canto inferior direito; C, D. concha de ostra fraturada diageneticamente, ao lado de fragmento de osso queimado. Imagens a polarizadores paralelos $(A, B, C)$ e cruzados (D).

A AFS3 é formada por três fácies que têm como característica em comum a presença de cascalho de conchas, sobretudo $A$. brasiliana, dominantemente inteiras, suportado pela matriz arenosa (Figura 95). Nas cinco datações feitas em conchas desta associação, as idades variaram de 4531 a 2853 anos cal AP, estando a moda (50\% das ocorrências) no intervalo entre 4000 e 3000 anos cal AP. 

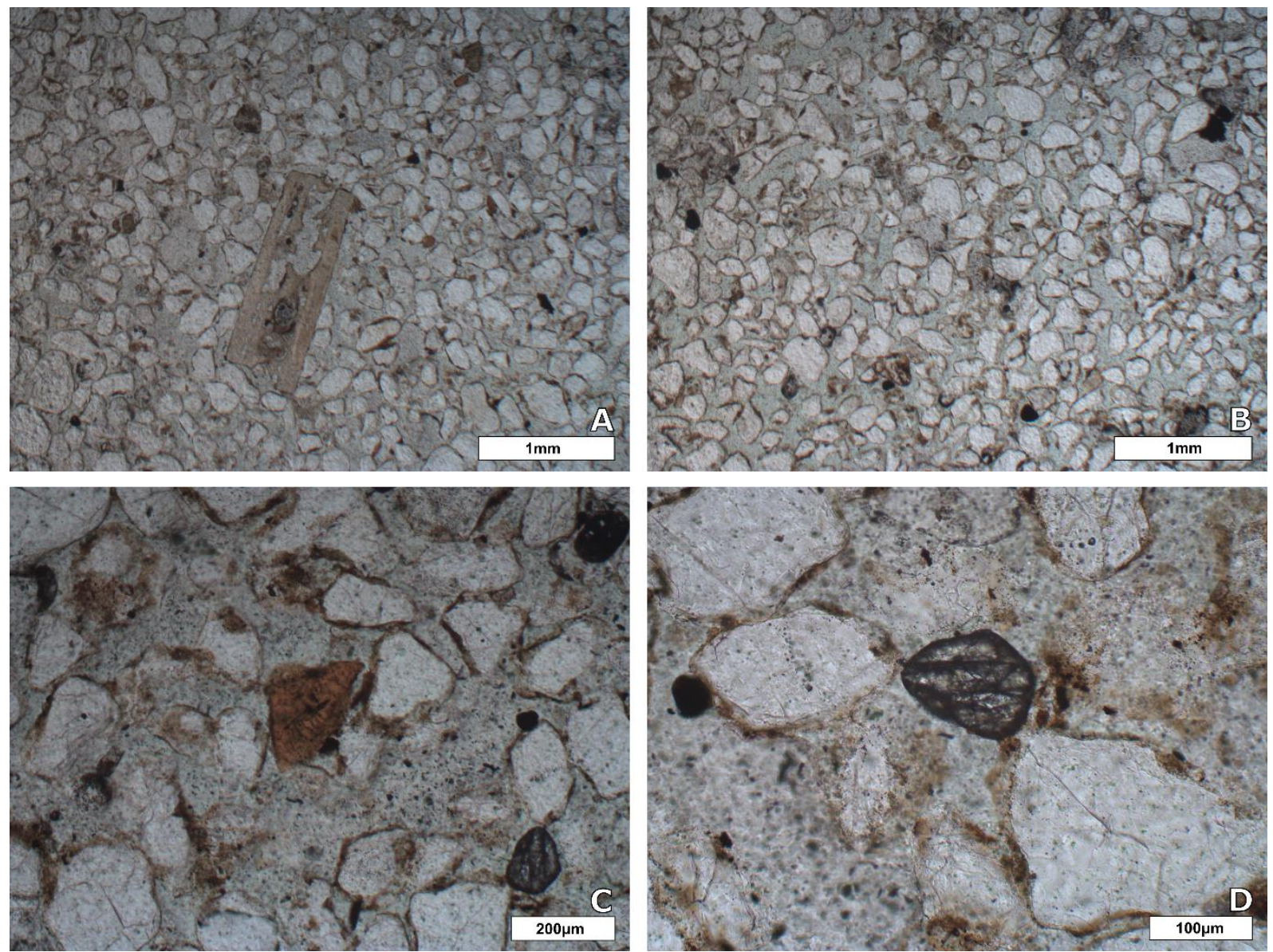

Figura 95. Fotomicrografias a polarizadores paralelos da camada 2 do sambaqui Cabeçuda (CB1-

C2), pertencente a AFS3. Notar areia terrígena bem selecionada, bioclasto de concha perfurado, provavelmente por dissolução $(B)$, bioclasto de osso $(C)$ e mineral pesado mais fino que o quartzo (C, D).

A AFS4 agrupa quatro fácies de cascalho clasto-suportado de conchas de $A$. brasiliana dominantemente inteiras, com matriz lamosa. Foram feitas nesta associação dez datações (uma em carvão, nove em conchas), cujos resultados variaram de 3867 a 2249 anos cal AP. A moda, com $70 \%$ das idades obtidas, foi o intervalo de 3000 a 2000 anos cal AP. Ao microscópio, a matriz mostra-se rica em fosfato finamente particulado (Figura 96). 

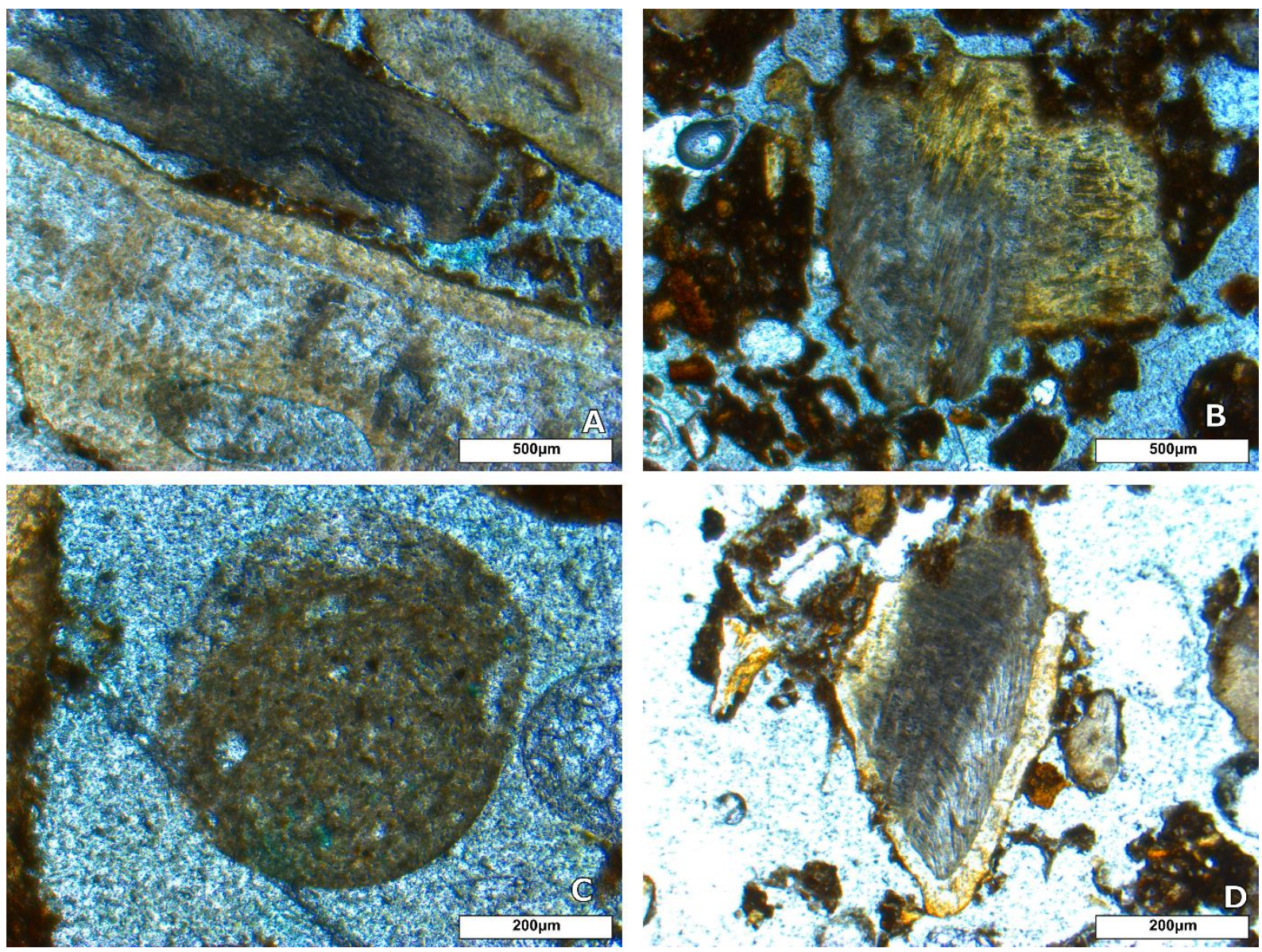

Figura 96. Fotomicrografias a polarizadores paralelos da camada 1 do sambaqui Jaboticabeira 1 (JCC1), pertencente a AFS4: A. bioclasto rudáceo de concha de molusco, com duplo revestimento: de microespato e de cimento fosfático granular; B. bioclasto carbonático com preenchimento alveolar (honeycomb) por cimento fosfático, cercado por fosfato bioclástico mais fino; C. peloide intraclástico de micrita; D. concha com cimento de microespato, retrabalhados.

Duas fácies que têm em comum a presença de cascalho conchífero de conchas dominantemente quebradas foram reunidas na AFS5 (Figura 97), representada em três sambaquis (Santa Marta, Caipora, Jaboticabeira 2). Foram obtidas cinco idades (uma em carvão, quatro em conchas), as quais variaram de 5800 a 1530 anos cal AP. O predomínio é de idades no intervalo de 3000 a 2000 anos cal AP, com 62,5\% das ocorrências. 

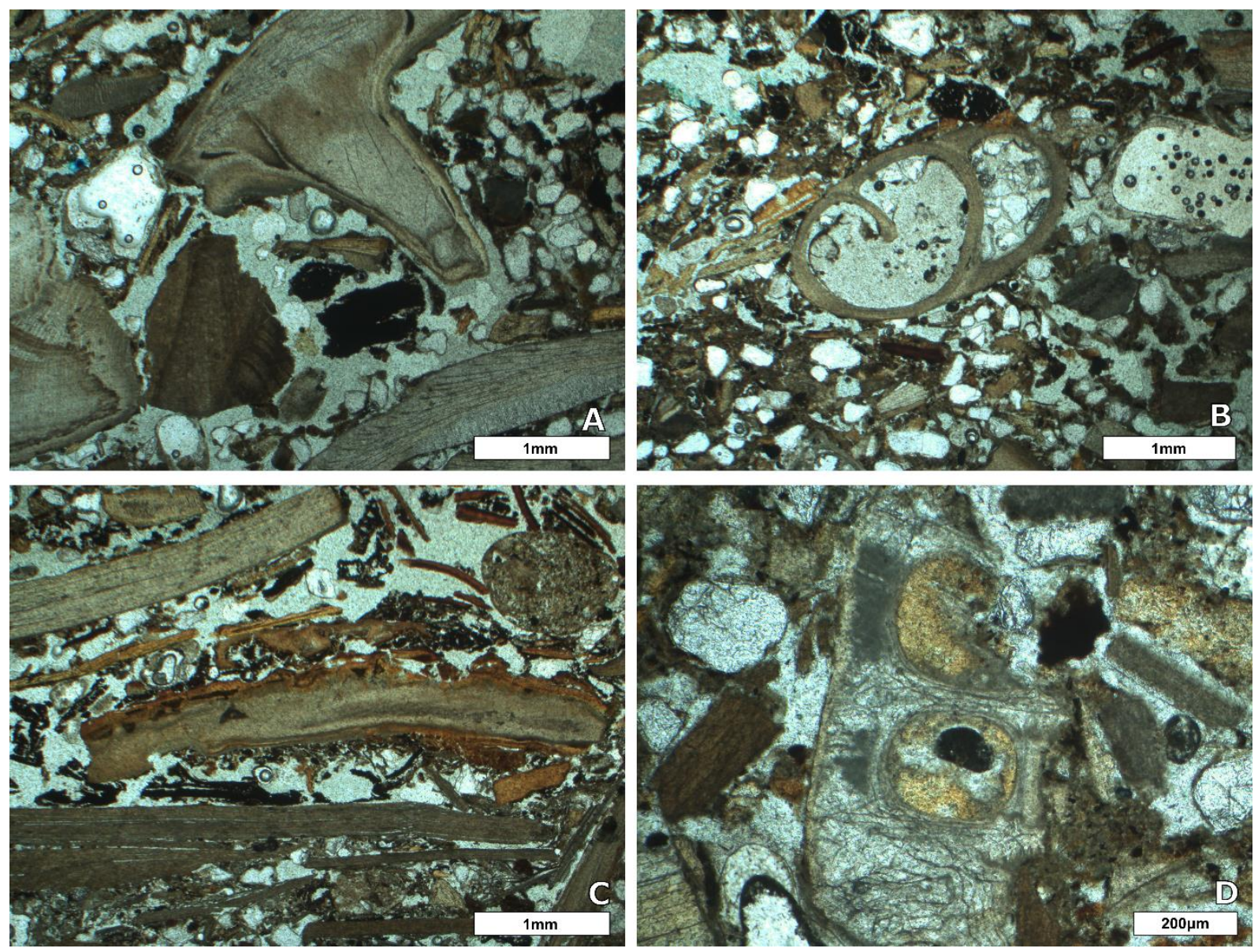

Figura 97. Fotomicrografias a polarizadores paralelos da camada 1 do sambaqui Jaboticabeira 2 (JBC1) pertencente a AFS5: A. cascalho bioclástico conchífero, com areia terrígena e fragmentos de carvão; B. bioclasto de gastrópode em meio a areia formada por terrígenos, ossos e carvão; C. bioclastos de moluscos, subparalelamente alinhados; notar também: peloide de micrita, fragmentos delgados de ossos e cimento fosfático revestindo a concha do meio da imagem; D. bioclasto de craca, com cimento intragranular de fosfamicrita.

A AFS6 é representada em quatro sambaquis diferentes e reúne cinco fácies que possuem em comum a sustentação por cascalho conchífero fino e a presença de matriz de conchas moídas. Ao microscópio, evidencia-se ainda a presença de areia terrígena, bioclastos de ossos e cimento fosfático (Figura 98). Nas sete datações feitas em conchas desta associação, os resultados variaram de 3023 a 1373 anos cal AP, portanto com forte concentração (90\%) das idades no intervalo de 3000 a 1000 anos cal AP. 

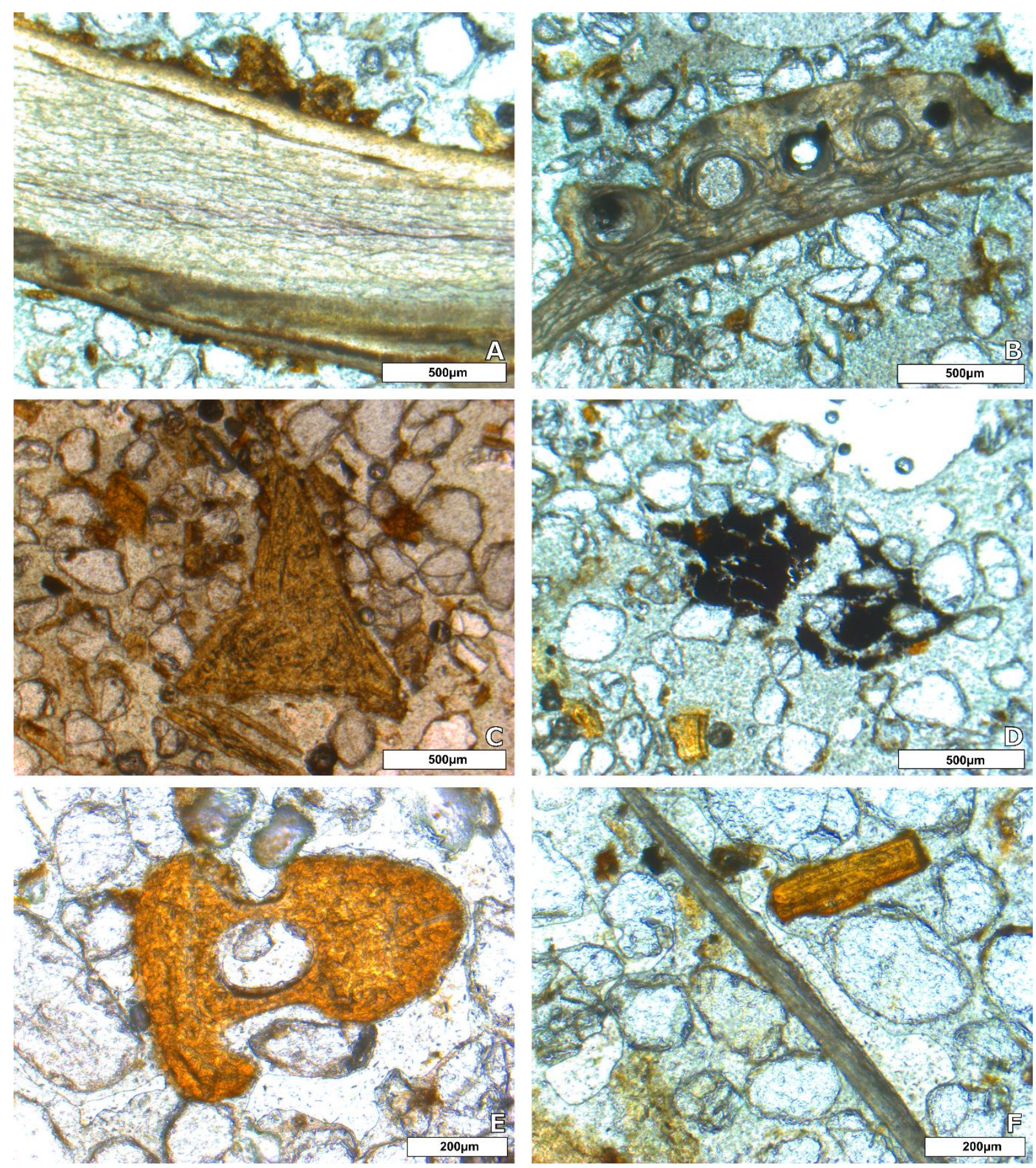

Figura 98. Fotomicrografias a polarizadores paralelos da camada 2 do sambaqui Garopaba do Sul (GS2-C2) pertencente a AFS6: A. concha com cimento anisópaco de fosfato; B. bioclasto de craca; C. bioclastos de ossos; D. túnel de bioturbação com preenchimento por pellets; E. bioclasto de osso; F. bioclastos de concha e de osso. Notar, em todas as imagens, presença de areia terrígena fina a média, bem selecionada. 
A AFS7 agrupa quatro fácies, ocorrentes em dois sambaquis (Carniça e Perrixil), caracterizadas pela presença de cascalho conchífero em matriz de ossos moídos. Ao microscópio, destaca-se ainda a presença de peloides de calcimicrita, inclusive amassados (Figura 99). As sete idades nela obtidas (quatro em carvão, três em concha) variam de 2459 a 1542 anos cal AP.
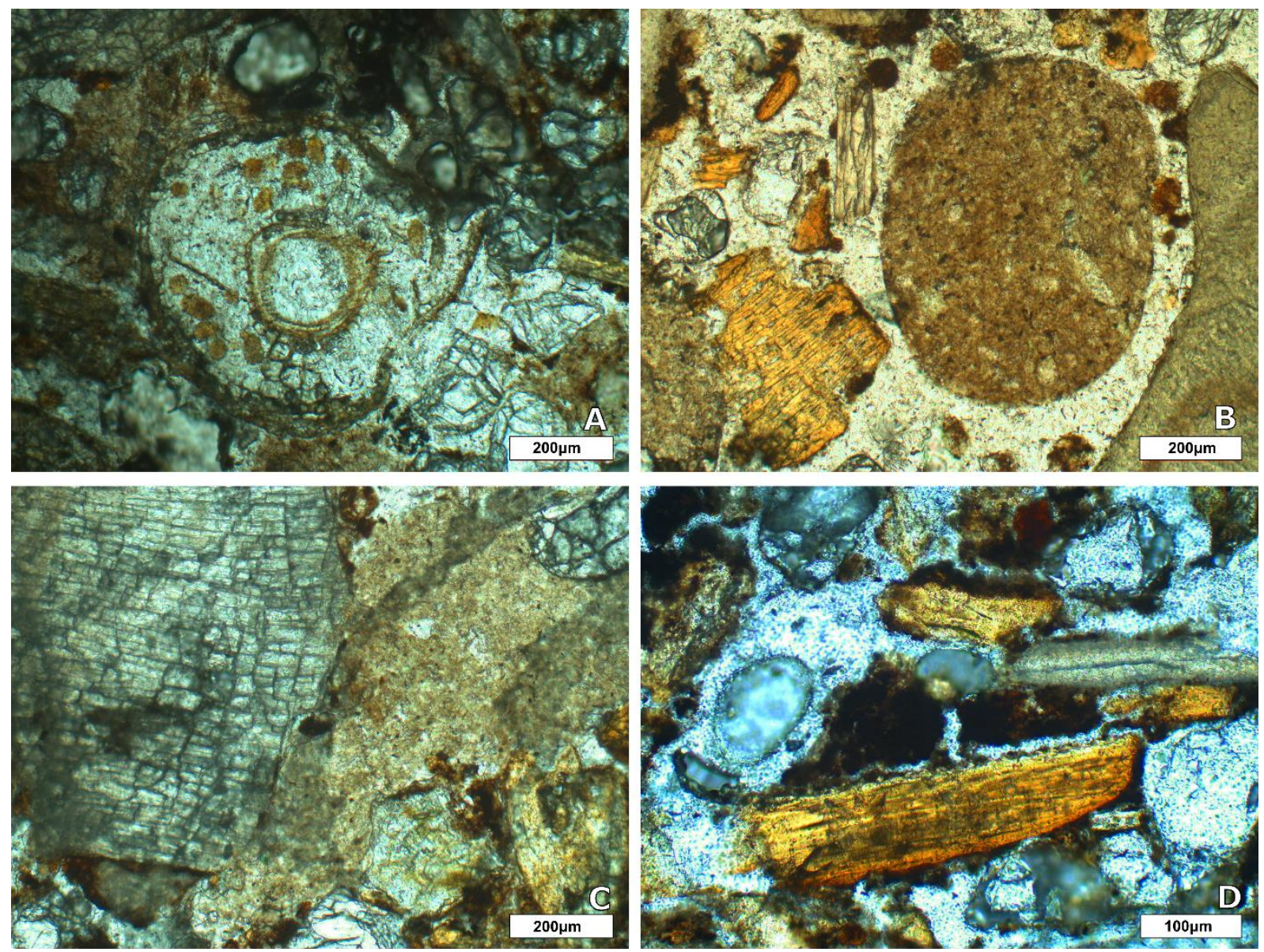

Figura 99. Fotomicrografias a polarizadores paralelos da camada 1 do sambaqui Carniça (CN3-C1) pertencente a AFS7: A. túnel de biotrbação, com preenchimento por pellets fosfáticos; B. peloide de callcimicrita, bioclastos de molusco e fragmento de osso com porosidade intragranular alveolar; C. bioclasto ladeado por calcimicrita, aparentemente amassada (pseudomatriz carbonática); D. ossos e possíveis pellets carbonosos.

A AFS8 é formada por uma única fácies presente no capeamento de "terra preta" do sambaqui Jaboticabeira 2 (Bendazzoli, 2007; Villagran, 2008, 2012; Menezes, 2009). Corresponde a areia lamosa com matriz de ossos moídos. $\mathrm{Na}$ literatura prévia, as idades para esta fácies vão de 1329-1178 (osso humano) a 34713219 (concha). Aqui, foram obtidas mais três idades a partir dos raros espécimes de conchas, variando de 1994 anos cal AP a 1737 anos cal AP. Portanto, todas as idades disponíveis para esta fácies estão concentradas no intervalo de 2000 a 1000 anos AP. 
Segunda etapa de agrupamento

$\mathrm{Na}$ segunda etapa do agrupamento de fácies, foram reconhecidos quatro conjuntos maiores de associações (Tabela 11).

Tabela 11. Conjuntos de associações de fácies

\begin{tabular}{|c|c|}
\hline Conjunto de associações de fácies & \begin{tabular}{c} 
Associações de fácies constituintes \\
\hline $\begin{array}{c}\text { Cascalho de conchas dominantemente } \\
\text { inteiras }\end{array}$
\end{tabular} AFS1, AFS3, AFS4 \\
\hline $\begin{array}{c}\text { Cascalho de conchas quebradas ou } \\
\text { com conchas/ ossos moídos }\end{array}$ & AFS2 \\
\hline Cascalho de ostras inteiras & AFS5, AFS6 e AFS7 \\
\hline Areia com ossos moídos & AF8 \\
\hline
\end{tabular}

O primeiro conjunto corresponde às fácies que contêm cascalhos de conchas de $A$. brasiliana dominantemente inteiras, com ou sem matriz de areia ou lama; resulta da junção das associações de fácies AFS1, AFS3 e AFS4. Este conjunto agrupa 12 fácies diferentes, com ocorrência distribuída em 11 sambaquis, e idades que vão desde 6452 até 1952 anos cal AP. Mais de 90\% das 53 datações computadas no diagrama de barras por milênio (Figura 100) distribuem-se, de modo relativamente equilibrado, ao longo do intervalo de 5000 a 2000 anos cal AP.

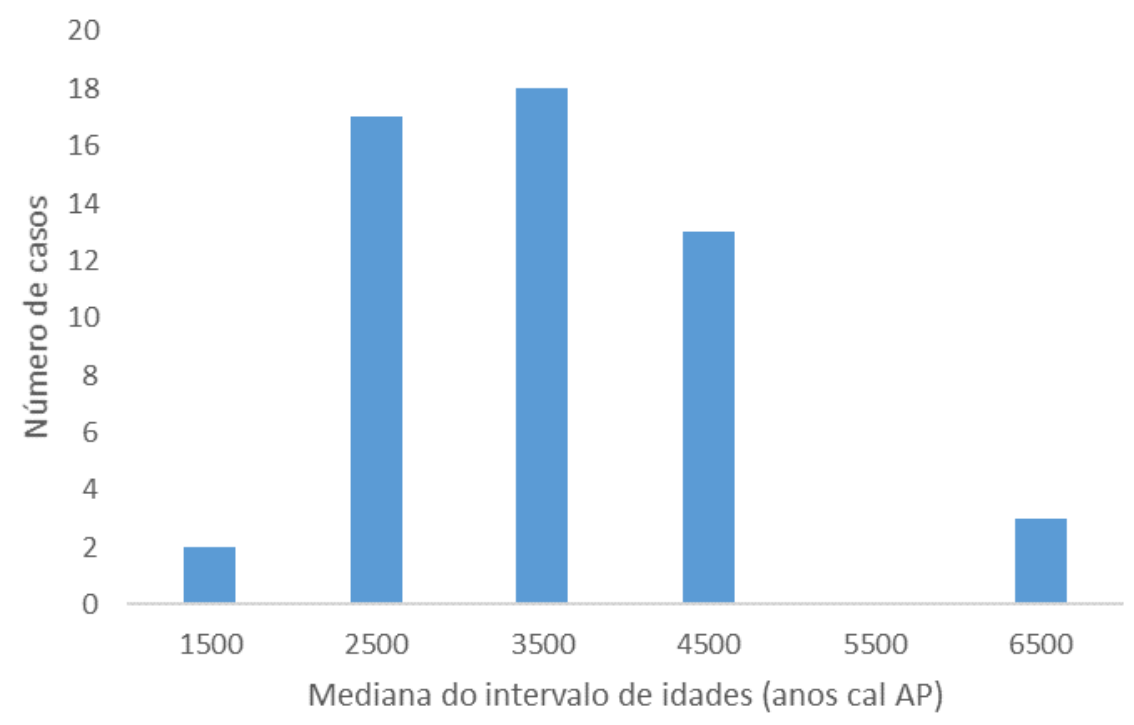

Figura 100. Diagrama de distribuição no tempo das associações de fácies contendo cascalho de conchas de $A$. brasiliana dominantemente inteiras, com ou sem matriz de areia ou lama (AFS1, AFS3

e AFS4). Para a elaboração do gráfico, considerou-se o intervalo inteiro de cada datação ${ }^{14} \mathrm{C}$. 
O segundo conjunto de associações de fácies é unitário, formado apenas por AFS2, e corresponde, portanto, aos cascalhos de ostras inteiras em matriz de concha moída. Este grupo é bastante restrito tanto no espaço, já que foi encontrado apenas nos sambaquis Caipora e Jaboticabeira 2, quanto no tempo, visto que se limita a intervalo de 6146 a 5573 anos cal AP (Figura 101), contemporâneo ou imediatamente anterior ao máximo NRM. Os dois sambaquis em que AFS2 ocorre têm em comum a associação com morros testemunho do embasamento cristalino pré-cambriano que, na época da máxima inundação, formavam ilhas ou promontórios no interior da paleobaía (Giannini et al. 2010), contexto favorável à abundância de ostras, a exemplo de outras faunas incrustantes, como equinoides, cujos vestígios de fato já haviam sido registrados previamente, via estudo micromorfológico, em arqueofácies do sambaqui Caipora (Villagran, 2012; Villagran \& Giannini, 2014). Este contexto explica a opção do sambaquieiro pelo uso das conchas de ostras como material construtivo, em alternativa a $A$. brasiliana. Um terceiro sambaqui de contexto paleogeográfico similar, com a única diferença de estar localizado na porção vale-laguna do sistema deposicional lagunar, e não na baía-laguna, é o Perrixil, onde fácies com ostras de fato também foram registradas, porém aqui correlacionadas a associação de fácies distinta em vista da presença marcante de outros tipos de materiais (ossos moídos), adotados como critério importante de distinção de fácies.

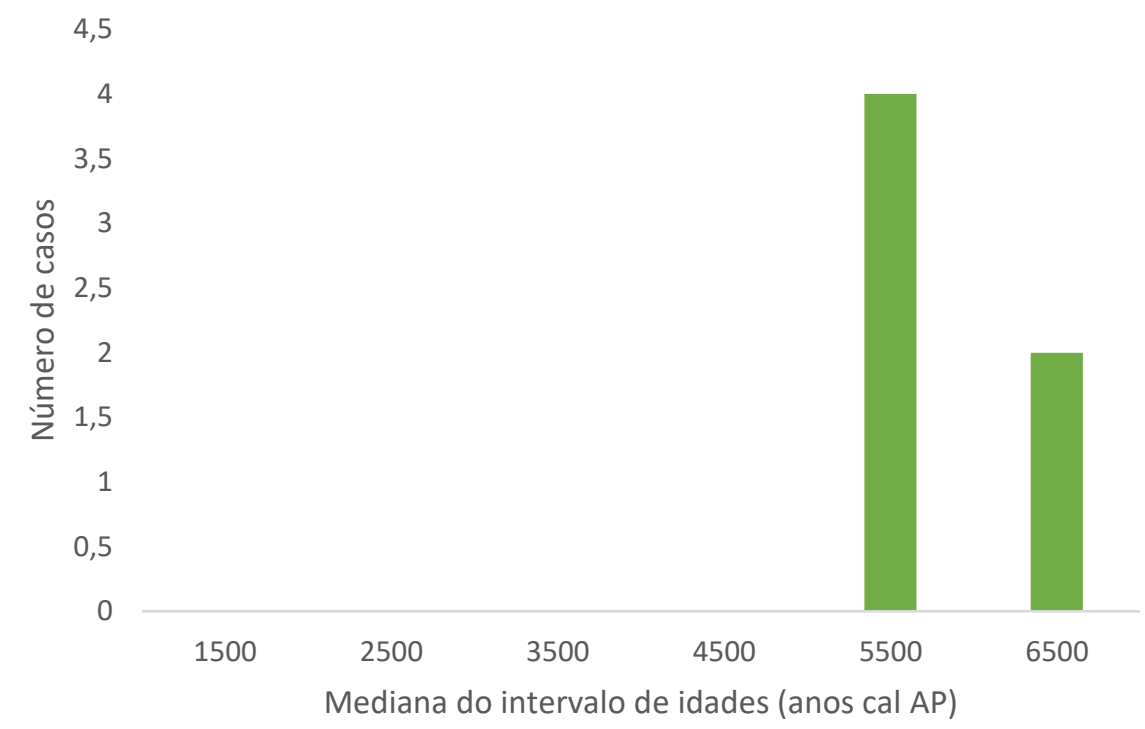

Figura 101. Diagrama de distribuição no tempo da associação de fácies de cascalho de ostras inteiras em matriz de concha moída (AFS2). Para a elaboração do gráfico, considerou-se o intervalo inteiro de cada datação ${ }^{14} \mathrm{C}$. 
O terceiro conjunto de associações de fácies corresponde ao agrupamento de AFS5, AFS6 e AFS7 e tem como característica distintiva a presença de cascalho de conchas de $A$. brasiliana quebradas e/ou com matriz de conchas ou ossos moídos. Este grupo integra 11 fácies, de sete sambaquis diferentes, com idades que vão de 5800 a 1542 anos cal AP, e com moda (92\% das datações) no período de 3000 a 1000 anos cal AP (Figura 102).

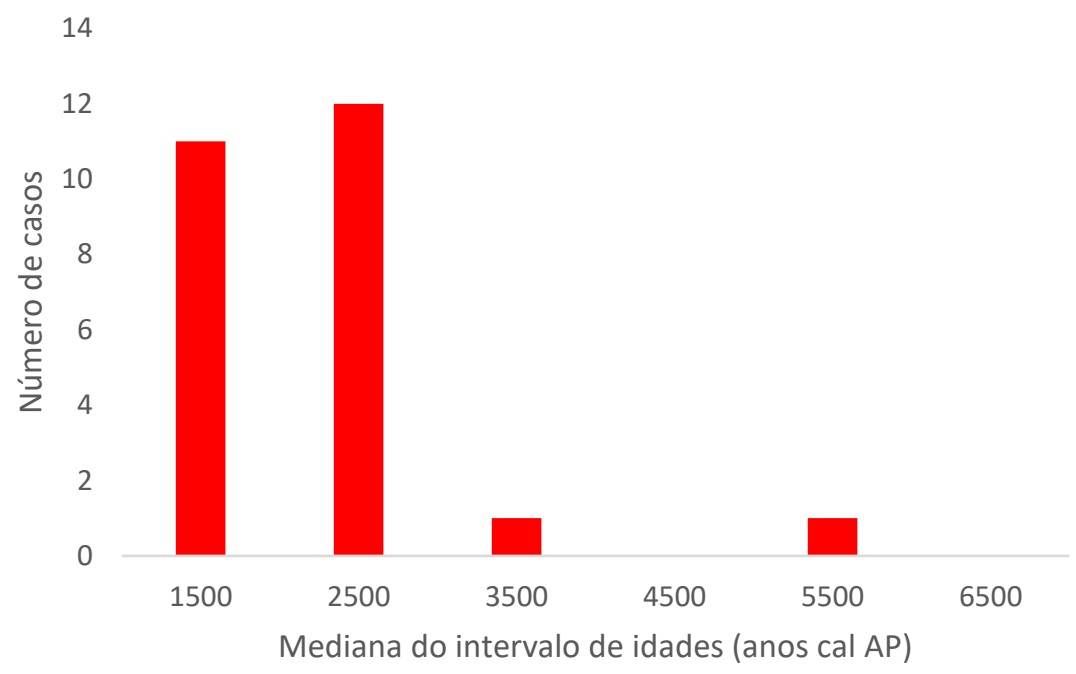

Figura 102. Diagrama de distribuição no tempo das associações de fácies contendo cascalho de conchas de A. brasiliana quebradas e/ou matriz de conchas ou ossos moídos (AFS5, AFS6 e AFS7). Para a elaboração do gráfico, considerou-se o intervalo inteiro de cada datação ${ }^{14} \mathrm{C}$.

O quarto agrupamento, a exemplo do segundo, é unitário, correspondente a areia lamosa com matriz de ossos moídos da AF8, cujas idades concentram-se no estreito intervalo de 1994 anos cal AP a 1737 anos cal AP (Figura 103).

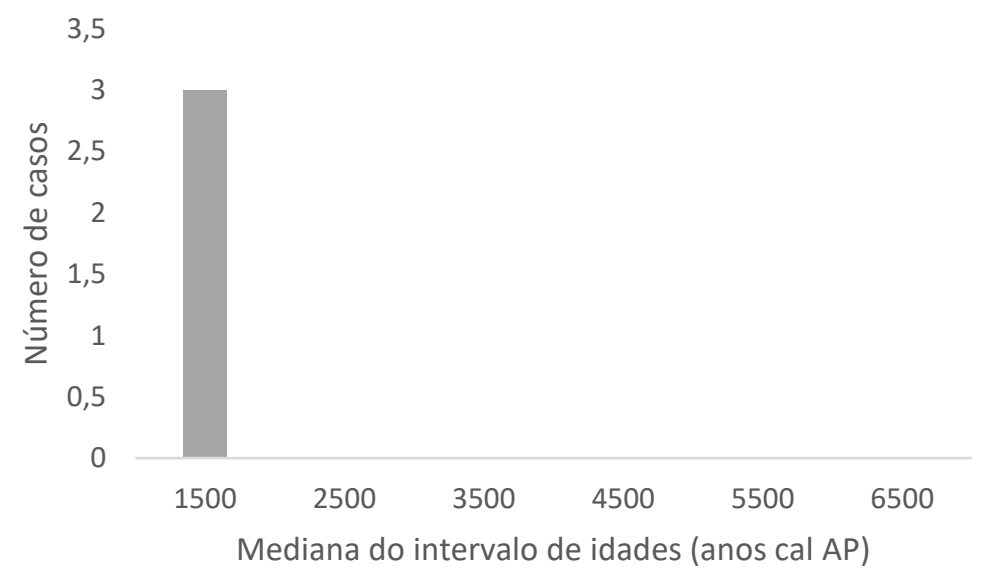

Figura 103. Diagrama de distribuição no tempo da associação de fácies de areia lamosa com matriz de ossos moídos (AFS8). Para a elaboração do gráfico, considerou-se o intervalo inteiro de cada datação ${ }^{14} \mathrm{C}$. 


\subsubsection{Correlações entre associações lagunares e de sambaquis}

A sucessão estratigráfica paleolagunar, de AFL1/ALF2 a AFL5, mostra tendência para aumento gradual na proporção de conchas quebradas, em detrimento das conchas inteiras. Em paralelo, de AFL2 a AFL5, tem-se aumento da quantidade relativa de matriz, em detrimento de material conchífero, e, ao mesmo tempo, tendência de afinamento desta matriz.

Analogamente, nos quatro grupos de AFS aqui identificados, tem-se, dos dois primeiros grupos, mais antigos, para o terceiro e o quarto, tendência para aumento gradual da representatividade de conchas quebradas, em detrimento das conchas inteiras, bem como aumento na quantidade relativa de matriz fina, em detrimento do material conchífero. Existe assim um paralelo ou correlação entre depósitos paleolagunares e sambaquis, no que se refere à variação da textura e composição ao longo das suas sucessões sedimentares, formadas contemporeamente, o que já havia sido destacado por Giannini et al. (2009) e Menezes (2009), nesse caso referindo-se especificamente à comparação do sambaqui Jaboticabeira 2 (Figura 104) com os depósitos naturais adjacentes.

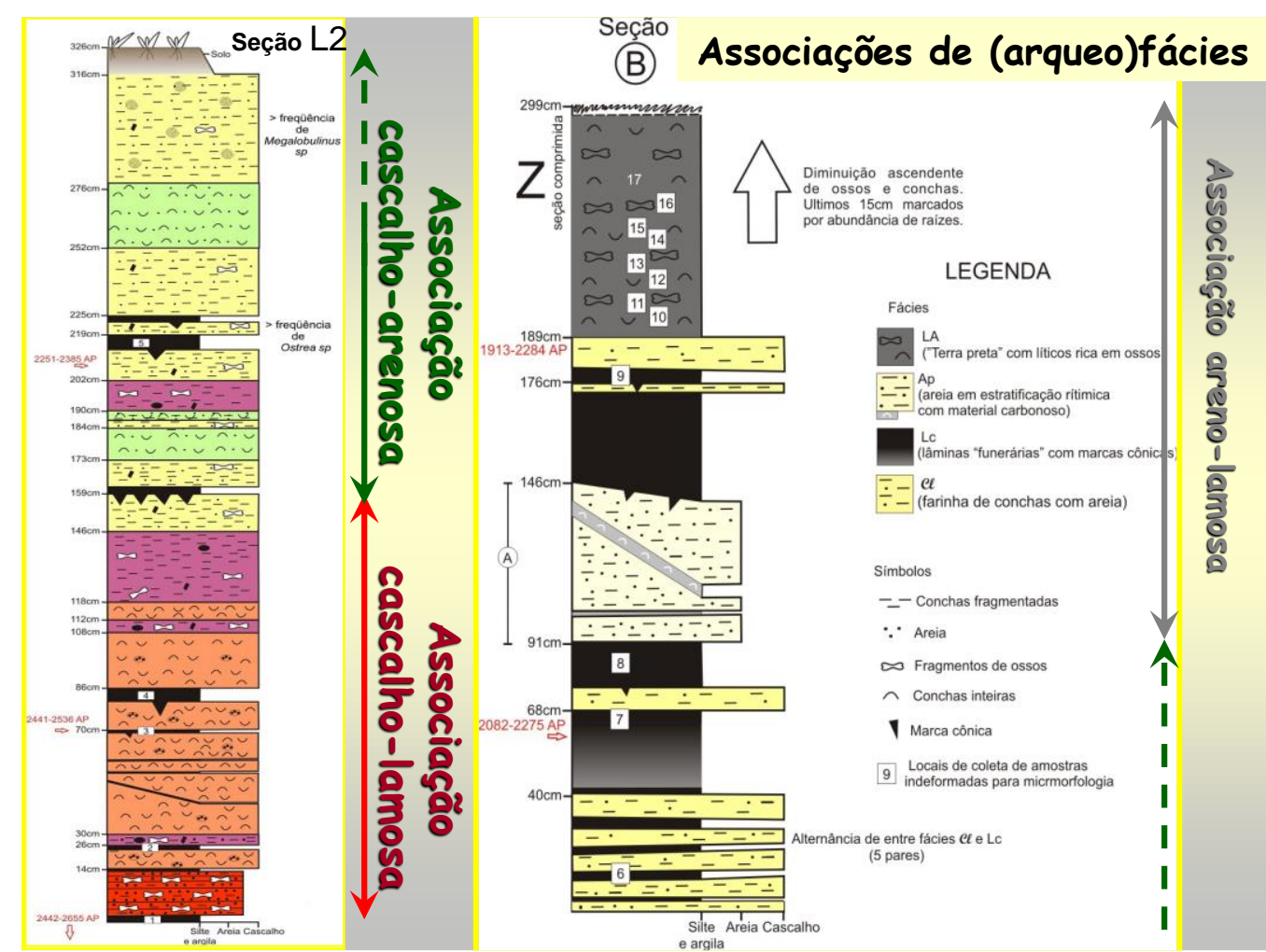

Figura 104. Representação esquemática das associações de fácies interpretadas por Giannini et al. (2009) e Menezes (2009) no sambaqui Jaboticabeira 2. Seção composta: L2 sob B. 
Esta semelhança deve-se ao fato de que a laguna é provavelmente a principal área fonte dos materiais utilizados na construção dos sambaquis, ou mais seguramente, a área fonte do principal material construtivo deste tipo de sítio arqueológico, que é a concha de molusco. $\mathrm{E}$ a disponibilidade desta matéria-prima depende da evolução da paleolaguna ao longo do tempo geológico. A sucessão estratigráfica paleolagunar demonstra que a concha de $A$. brasiliana desaparece gradualmente do registro sedimentar. No tocante aos condicionantes naturais, este desaparecimento pode ter dois fatores controladores. O primeiro é a simples migração centrípeta (tomando como centro a parte mais profunda da laguna) das fácies na paleogeografia em resposta à sedimentação regressiva. $O$ hábitat deste molusco corresponde, por excelência, à zona inframaré, abaixo do nível de base de ondas, ou ainda, à zona intermarés, mas em áreas protegidas da circulação hidrodinâmica, portanto às porções mais profundas e/ou calmas do sistema lagunar. À medida que, com o abaixamento de NRM no Holoceno superior, o sistema lagunar é assoreado, as zonas inframarés deste sistema diminuem gradualmente em área, tanto em termos absolutos quanto relativos, deslocando-se em direção ao depocentro da laguna. Os bancos de moluscos acompanham esse encolhimento em área da zona inframaré e o deslocamento de fácies associado e, com isso, afastam-se progressivamente das áreas emersas escolhidas pelos sambaquieiros para erigir seus depósitos, à medida que as zonas supra e intermarés se ampliam. Os moluscos vivos, e mesmo as conchas inteiras e articuladas de espécimes mortos, tornam-se de acesso cada vez mais difícil, ao mesmo tempo em que as áreas intermarés, ricas em areias conchíferas e em cascalhos de bioclastos fragmentados, oferecem alternativas de obtenção de material construtivo conchífero (Tabela 12).

Tabela 12. Correlação cronológica entre associações de fácies lagunares e de sambaquis. $\mathbf{X}$ negrito: ocorrência modal. Número negrito preto: idade máxima obtida em AFL. Número negrito azul: idade mínima obtida em sambaqui. Demais idades são aproximadas, com base no predomínio no conjunto de dados de datações desta tese. Deposição de AFL 3 a AFL5 é contínua a partir de 5300 anos AP.

\begin{tabular}{|c|c|c|c|c|c|c|}
\hline \multirow{3}{*}{$\begin{array}{l}\text { Associação de } \\
\text { fácies lagunar }\end{array}$} & \multirow{3}{*}{$\begin{array}{l}\text { Intervalo } \\
\text { de idades } \\
\text { (anos cal } \\
\text { AP) }\end{array}$} & \multirow{3}{*}{ Significado geológico } & \multicolumn{4}{|c|}{$\begin{array}{c}\text { Conjuntos de associações de fácies } \\
\text { de sambaqui }\end{array}$} \\
\hline & & & 1 & 2 & 3 & 4 \\
\hline & & & $\begin{array}{c}\text { Concha } \\
\text { inteira }\end{array}$ & $\begin{array}{l}\text { Ostra } \\
\text { inteira }\end{array}$ & $\begin{array}{c}\text { Concha } \\
\text { quebrada }\end{array}$ & $\begin{array}{l}\text { Osso } \\
\text { moido }\end{array}$ \\
\hline $\begin{array}{c}\text { AFL1: cascalho de } \\
\text { concha inteira }\end{array}$ & $7085-5880$ & Lags transgressivos & $x$ & $\mathbf{x}$ & & \\
\hline $\begin{array}{l}\text { AFL2: conchas } \\
\text { em posição de } \\
\text { vida }\end{array}$ & $5880-5300$ & $\begin{array}{l}\text { Máxima inundação } \\
\text { máximo NRM }\end{array}$ & $\mathrm{x}$ & $\mathbf{x}$ & $\mathrm{X}$ & \\
\hline $\begin{array}{l}\text { AFL3: cascalho de } \\
\text { concha quebrada }\end{array}$ & $5300-4000$ & $\begin{array}{l}\text { Regressão } 1- \\
\text { acumulação inframaré }\end{array}$ & $\mathbf{x}$ & & $x$ & \\
\hline
\end{tabular}




\begin{tabular}{|c|c|c|c|c|c|c|}
\hline \multirow{3}{*}{$\begin{array}{l}\text { Associação de } \\
\text { fácies lagunar }\end{array}$} & \multirow{3}{*}{$\begin{array}{c}\text { Intervalo } \\
\text { de idades } \\
\text { (anos cal } \\
\text { AP) }\end{array}$} & \multirow{3}{*}{ Significado geológico } & \multicolumn{4}{|c|}{$\begin{array}{c}\text { Conjuntos de associações de fácies } \\
\text { de sambaqui }\end{array}$} \\
\hline & & & 1 & 2 & 3 & 4 \\
\hline & & & $\begin{array}{c}\text { Concha } \\
\text { inteira }\end{array}$ & $\begin{array}{r}\text { Ostra } \\
\text { inteira }\end{array}$ & $\begin{array}{c}\text { Concha } \\
\text { quebrada }\end{array}$ & $\begin{array}{l}\text { Osso } \\
\text { moido }\end{array}$ \\
\hline $\begin{array}{l}\text { AFL4: areia com } \\
\text { concha quebrada }\end{array}$ & $\begin{array}{l}4000-3000 \\
3000-2000\end{array}$ & $\begin{array}{l}\text { Regressão } 2 \text { - } \\
\text { acumulação intermarés }\end{array}$ & $\begin{array}{l}X \\
X\end{array}$ & & $X$ & \\
\hline $\begin{array}{l}\text { AFL5: Iama } \\
\text { turfosa }\end{array}$ & $2000-1542$ & $\begin{array}{c}\text { Regressão } 3 \text { - } \\
\text { acumulação supramaré }\end{array}$ & & & $\mathbf{x}$ & $x$ \\
\hline
\end{tabular}

O segundo fator que pode ter determinado a redução da disponibilidade de $A$. brasiliana, sem necessariamente excluir o fator anterior, é a queda da própria população de moluscos vivos, em resposta a mudanças nas condições ambientais, por exemplo profundidade e, sobretudo, salinidade das águas. Este aspecto é discutido no subitem a seguir.

\subsection{Evolução ambiental e mudança na composição faunística}

Os resultados de $\delta^{18} \mathrm{O}$ das conchas de $A$. brasiliana analisadas variam entre valores negativos $(-0,75 \%$ a $-1,94 \%$ ), com amplitude absoluta de apenas $1,19 \%$. Este intervalo de valores é menos negativo que o intervalo de valores médios por concha de molusco vivente da mesma espécie e região, obtidos por Colonese et al. (2017) via análise esclerocronológica $(-1,6 \%$ a $-2,2 \%$, com variação total por esclera de $-3,0 \%$ a $0,4 \%$ ). Já os valores médios obtidos por mesmo autor para conchas fósseis de cerca de 3 ka do sambaqui Cabeçuda (-1,4\%o a -1,7\%o, com variação total por esclera de $3,0 \%$ a $0,3 \%$ o) caem dentro do intervalo encontrado aqui.

Considerando que o $\delta^{18} \mathrm{O}$ de uma concha em equilíbrio com a água do mar deveria ser igual a 0\%oPDB, os valores negativos encontrados neste estudo devem-se à influência do aporte de água doce continental no sistema lagunar, o que é reforçado pela correlação direta encontrada por Colonese et al. (2017) entre salinidade do sistema lagunar centro-sul catarinense e $\delta^{18} \mathrm{O}$ de conchas de $A$. brasiliana coletados vivos. Assim, a salinidade pode ser tomada como principal fator ambiental determinante dos valores de $\delta^{18} \mathrm{O}$ das conchas desse molusco na região. Seguindo essa linha de raciocínio, os dois maiores picos de elevação do $\delta^{18} \mathrm{O}$, o principal deles em cerca de 5,25 ka atrás e o subordinado em 7 ka (Figura 105 D), devem estar ligados com momentos de redução do aporte de água doce e/ou de aumento da ingressão marinha nas antigas lagunas ou baías. De fato, a idade de $7 \mathrm{ka}$ coincide com o momento em que o NRM (Figura 105 A) alcançou o nível atual pela primeira vez no 
Holoceno, nesta região (Martin et al. 1988, Angulo et al. 2006), e também com a época aproximada da máxima inundação marinha (Fornari et al. 2012); e a idade de 5,25 ka coincide com a época do máximo NRM na costa centro-sul catarinense (Martin et al. 1988, Angulo et al. 1999, 2006). Desse modo, os picos menos negativos de $\delta^{18} \mathrm{O}$ encontrados nas conchas analisadas nesta tese aparentemente refletem, com grande fidelidade, dois eventos marcantes da evolução paleogeográfica regional, relacionados sobretudo a NRM (alto) e posição da linha de costa (avançada rumo continente). Já o valor mais baixo, encontrado em torno de 1,5 ka AP, coincide com um evento Bond, quando a precipitação e, por consequência, o aporte de água doce no sistema lagunar podem ter aumentado (Amaral et al. 2012). Os dados de espeleotemas em Santa Catarina de Bernal et al. (2016) mostram intensificação da precipitação média regional a partir de $7 \mathrm{ka}$, com o máximo alcançado em 4 ka e manutenção desde então (Figura 105 B). Alternativamente, pode-se atribuir este pico negativo a fatores autogênicos capazes de elevar o suprimento de águas fluviais nos setores lagunares amostrados neste trabalho, por exemplo, mudança de posição dos distributários ativos do delta do rio Tubarão. Nascimento Jr. (2011) demonstrou, por análise estatigráfica associada a datações, a intensa dinâmica da frente deltaica, em escala milenar.

A tendência de queda dos valores medianos de $\delta^{18} \mathrm{O}$ no período de $7,0 \mathrm{ka}$ a 5,5 ka AP pode significar que, apesar de o NRM estar em suave subida nessa época (Angulo et al. 2006, Toniolo 2014, 2017), o aporte de água doce crescia, seja por elevação da precipitação, seja porque a barreira arenosa transgressiva já estivesse formada por volta de $7 \mathrm{ka}$, e, com isso, o sistema já evoluía da fase de baía, mais aberta, para laguna, mais fechada e com maior retenção das águas continentais. $O$ segundo período de queda de $\delta^{18} \mathrm{O}$, entre a época do máximo $\mathrm{NRM}$ e $1,5 \mathrm{ka} A P$, associa-se ao fechamento cada vez maior do sistema lagunar, por conta de seu assoreamento e da rápida progradação da costa, agora sob NRM em queda, como já cogitado, com base neste e em outros tipos de indicadores, por Fornari et al. (2012), Giannini et al. (2010) e Nascimento Jr. (2011). Note-se que os valores médios encontrados por Colonese et al. (2017) em conchas de moluscos viventes são ainda mais negativos que os valores medianos da curva de variação apresentada nesse trabalho, sugerindo que o aumento da influência de água doce segue até o presente. 
Considera-se que o desvio padrão dos dados geoquímicos e isotópicos em dado intervalo de tempo reflita a influência de diferentes ambientes geoquímicos naquele momento, o que é favorecido paleogeografias complexas ou em mudança brusca. Assim, o aumento de dispersão de resultados nos dois extremos da curva de variação do $\delta^{18} \mathrm{O}$ no tempo pode representar a maior variabilidade de aporte fluvial e/ou de dinâmica sedimentar, em duas épocas do registro: entre a máxima inundação e o máximo NRM; e de 2 ka a 1 ka atrás. A maior variabilidade antes de $6 \mathrm{ka}$ pode ser atribuída à rápida e drástica mudança paleogeográfica na época do final da transgressão e da máxima inundação, que é quando se tem, provavelmente, a formação da barreira costeira arenosa a sul do cabo Santa Marta (FEG 1 de Fornari et al. 2012). Já o aumento de variabilidade dos últimos 2 ka de registro pode ser atribuído a mudanças na posição da frente deltaica do rio Tubarão e/ou ao aumento da influência de eventos El Niño, cuja intensidade teria aumentado a partir de 2,5 ka (Moy et al. 2002, Conroy et al. 2010), o que teria incrementado também a amplitude de variação no tempo das chuvas e da vazão fluvial.

Os valores de $\delta^{13} \mathrm{C}$ das conchas (Figura $105 \mathrm{D}$ ) são essencialmente positivos e apresentam amplitude de variação absoluta similar à do $\delta^{18} \mathrm{O}(1,68 \%)$. Contrastam assim com os valores médios por concha encontrados por Colonese et al. (2017) via esclerocronologia de espécimes viventes, os quais são essencialmente negativos ($0,9 \%$ a $0,0 \%$, com amplitude total de variação por esclera de $-4,2$ a 0,0$)$. Os valores aqui encontrados são parecidos, porém, com os obtidos por mesmos autores na análise esclerocronológica de conchas fósseis ( $3 \mathrm{ka}$ ) do sambaqui Cabeçuda (média de $0,8 \%$ a $0,9 \%$ e amplitude total de $-0,5 \%$ a $1,7 \%$ ). A correlação linear direta entre $\delta^{13} \mathrm{C}$ e $\delta^{18} \mathrm{O}$ permite sugerir que ambos sejam controlados por mesmos fatores, ou seja, precipitação e paleogeografia, os quais determinam o grau de mistura entre águas continentais e marinhas. Pesa a favor desta interpretação o fato de o padrão de variação do $\delta^{13} \mathrm{C}$ no tempo ser também bastante similar ao observado nos valores de $\delta^{18} \mathrm{O}$ : o pico em 7 ka está de novo presente, bem como como dois picos menores por volta da época de máximo NRM; o valor mais baixo é registrado na mesma época do pico negativo de $\delta^{13} \mathrm{C}, 1,5$ ka atrás. Estão presentes também a tendência de queda dos valores medianos no decorrer do tempo, mais acentuada e contínua nos últimos 4,5 ka, e o aumento na dispersão dos valores nos dois extremos do intervalo total de tempo coberto pelas datações. Devido à influência da matéria orgânica (processos de respiração e decomposição aeróbica), o $\delta^{13} \mathrm{C}$ do CID (carbono inorgânico dissolvido) 
da água doce é bem menor que o da água marinha. Em consequência disso, o $\delta^{13} \mathrm{C}$ de conchas de moluscos de estuários e lagunas pode ser usado como um traçador da maior ou menor influência marinha (Mook 1971, Chanton e Lewis 1999).

Os valores de $\mathrm{Mg} / \mathrm{Ca}$ das conchas de $A$. brasiliana tiveram amplitude de variação de $0,32 \mathrm{mmol} / \mathrm{mol}$ (Figura $105 \mathrm{E}$ ). A dispersão dos valores foi relativamente muito elevada $(>0,2 \mathrm{mmol} / \mathrm{mol})$ ao longo de todo o intervalo de tempo coberto pela amostragem (Figura 85). Assim, a única afirmação segura que se pode fazer é acerca do trecho da curva entre $6 \mathrm{ka}$ e $5 \mathrm{ka}$, no qual tanto valores medianos de $\mathrm{Mg} / \mathrm{Ca}$ quanto o envelope (desvio padrão) da curva mostram tendência de crescimento.

A relação entre o teor de $\mathrm{Mg}$ na calcita inorgânica e a temperatura ambiente é bem estabelecida. Na estrutura desse mineral, o $\mathrm{Mg}$ substitui facilmente $\circ \mathrm{Ca}$, pois tanto $\mathrm{O} \mathrm{MgCO}_{3}$ como a calcita formam cristais romboédricos. Como a reação de substituição é endotérmica, em cristais de calcita a razão $\mathrm{Mg} / \mathrm{Ca}$ aumenta junto com a temperatura, o que é bem demonstrado experimentalmente (Kinsman \& Holland 1969). A relação do teor de $\mathrm{Mg}$ com a temperatura é amplamente aceita também na maioria das espécies de concha ou esqueleto calcítico (Rosenthal et al. 1997, Klein et al. 1996). Em experimentos de precipitação de aragonita inorgânica, também se observa, relação direta entre o teor de $\mathrm{Mg}$ e a temperatura de cristalização (Kinsman \& Holland 1969), embora o mecanismo de incorporação do Mg na estrutura cristalina deste mineral seja mais complexo. A capacidade da aragonita em admitir Mg em substituição aleatória ao $\mathrm{Ca}$ na sua estrutura cristalina é muito limitada, em comparação com a calcita (Takesue et al. 2008). Em corais aragoníticos, os mecanismos controladores da entrada do Mg no retículo são pouco claros, mas há evidência para a relação diretamente proporcional entre o teor de $\mathrm{Mg}$ e a paleotemperatura da água (Amiel et al. 1973, Wei et al. 1999). Já no caso dos moluscos de concha aragonítica, existe menos consenso sobre o controle termodinâmico na razão $\mathrm{Mg} / \mathrm{Ca}$ (Schöne et al. 2003). Investigações em diferentes espécies de bivalves relatam relação direta entre temperatura e essa razão elementar (Klein et al. 1996, Ullmann et al. 2013), enquanto que outros (Wanamaker et al. 2008, Poulain et al., 2015) apontam para a ausência de controle termodinâmico e a predominância do controle biológico.

Se for admitida a correlação direta do $\mathrm{Mg} / \mathrm{Ca}$ com a temperatura das águas do sistema lagunar, a elevação de Mg/Ca entre 6 e 5 ka pode ser atribuída ao aumento 
da temperatura da água do sistema lagunar, provavelmente por influência do aquecimento das águas do mar, nesse período.

Os valores de $\mathrm{Sr} / \mathrm{Ca}$ das conchas de $A$. brasiliana analisadas, com amplitude absoluta de $0,49 \%$, mostram tendência de crescimento suave ao longo dos últimos 4 a 3,5 ka (Figura $105 \mathrm{~F}$ ). O Sr substitui facilmente o $\mathrm{Ca}$ em cristais de aragonita, visto que $\mathrm{SrCO}_{3}$ e $\mathrm{CaCO}_{3}$ na forma de aragonita formam cristais isoestruturais (ambos ortorrômbicos). Como esta reação de substituição é exotérmica, teoricamente em cristais de aragonita a razão Sr/Ca diminui com o aumento da temperatura (Kinsman \& Holland 1969). A partir dessa premissa, a razão $\mathrm{Sr} / \mathrm{Ca}$ tem sido usada como paleotermômetro inverso, com sucesso notadamente em corais (Weber, 1973; Smith et al. 1979; Beck et al. 1992). Em moluscos, no entanto, o uso dessa razão como indicador de temperatura é mais complexo e menos consensual (Schöne et al., 2003). Gillikin et al. (2005) e Sosdian et al. (2006), estudando moluscos vivos, concluíram que o controle biológico a incorporação do $\mathrm{Sr}$ (maior com a aumento da taxa de crescimento da concha) possa se sobrepor ao controle termodinâmico. Se, apesar destas ressalvas, o $\mathrm{Sr} / \mathrm{Ca}$ das conchas de $A$. brasiliana for admitido como indicador inverso de paleotemperatura das águas da laguna, os resultados encontrados indicam declínio de temperatura das águas ao longo do Holoceno superior. Em vermetídeos, crises populacionais no Holoceno superior, coincidentes com momentos de aumento da razão $\mathrm{Sr} / \mathrm{Ca}$ em suas carapaças, foram interpretadas como relacionadas a resfriamento das águas marinhas em que este gastrópode incrustante vivia (Toniolo 2014, 2017).

Os valores de $\mathrm{Ba} / \mathrm{Ca}$ das conchas de $A$. brasiliana analisadas apresentaram amplitude de variação de 4,3\%, com elevada dispersão. Apesar disso, o envelope de variação mostra tendência de crescimento entre 3,5 ka e 1 ka (Figura $105 \mathrm{G}$ ). Como a razão $\mathrm{Ba} / \mathrm{Ca}$ é, em média, muito maior nos rios do que nas águas oceânicas superficiais, ela pode ser usada como indicador da influência da descarga fluvial em ambientes costeiros, o que é bastante aceito tanto em corais (McCulloch et al., 2005) como em bivalves (Poulain et al., 2015, Gillikin et al., 2005). Admitida esta premissa, a elevação da razão $\mathrm{Ba} / \mathrm{Ca}$ ao longo do Holoceno superior seria um indicativo de aumento da diluição das águas marinhas pelas continentais dentro do sistema lagunar, seja por aumento de precipitação seja por fechamento progressivo da conexão da laguna com o mar, sob condição de NRM declinante. 
G

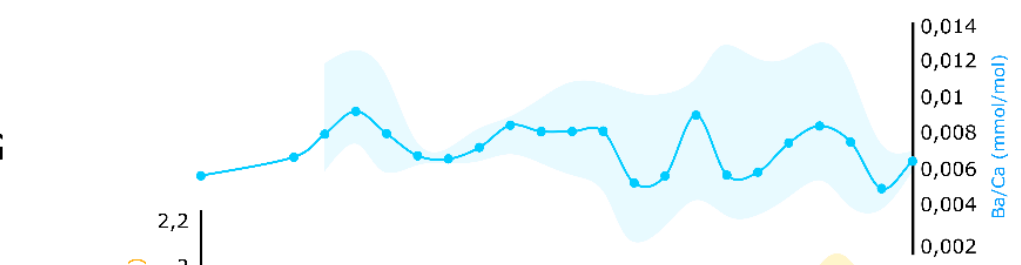

$\mathrm{E}$

$\mathrm{F}$

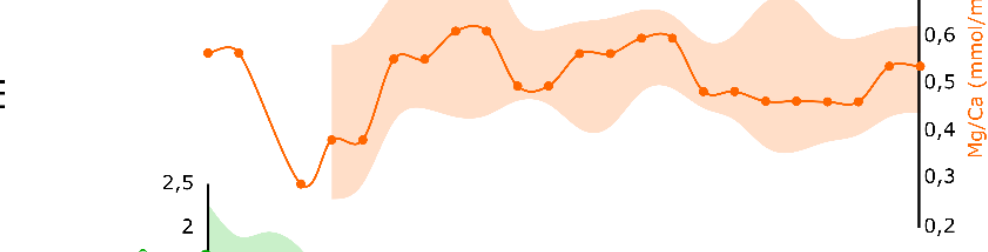

D

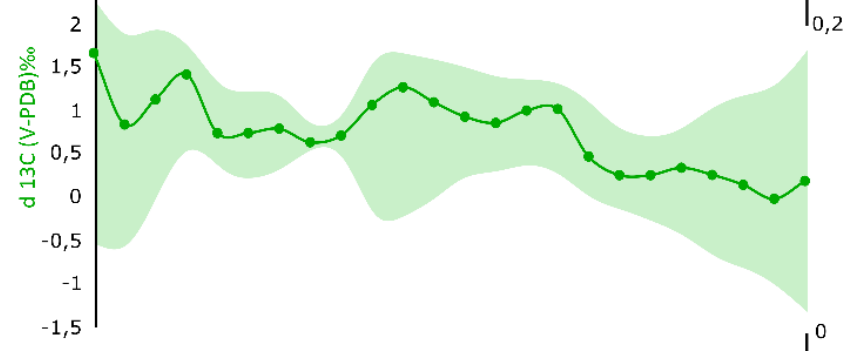

C

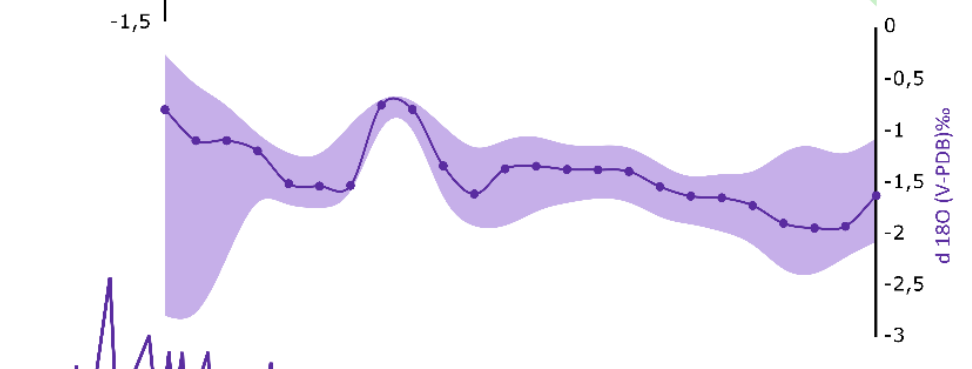

B

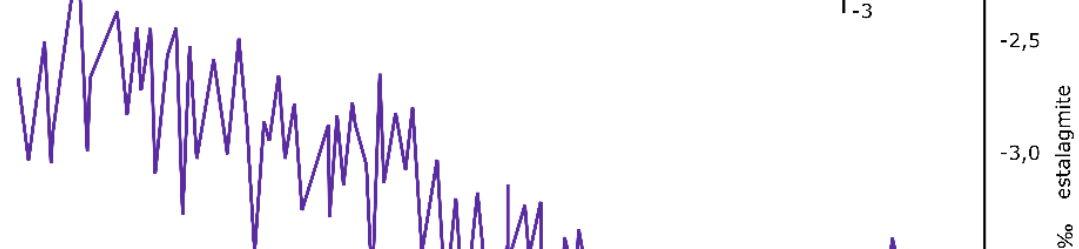

A

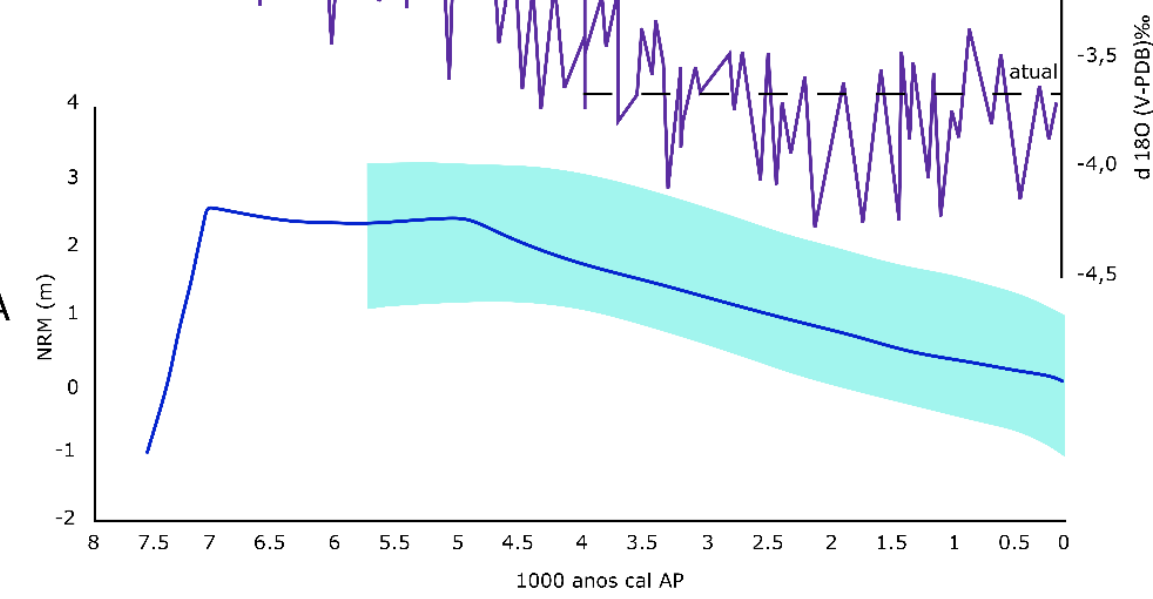

Figura 105. Confronto entre dados da literatura (A, B) e os resultados obtidos nesse trabalho (C-G): A) curva do NRM para o Estado de Santa Catarina (Angulo et al., 2006); B) $\delta^{18} \mathrm{O}$ de uma estalagmite da caverna Botuverá localizada no mesmo Estado (Bernal et al., 2016); C-G) valores de $\delta^{18} \mathrm{O}$ (C), $\delta^{13} \mathrm{C}(\mathrm{D})$ e das razões elementares de $\mathrm{Mg} / \mathrm{Ca}(\mathrm{E}), \mathrm{Sr} / \mathrm{Ca}(\mathrm{F})$ e $\mathrm{Ba} / \mathrm{Ca}(\mathrm{G})$ de conchas de $\mathrm{A}$. brasiliana de sambaquis e depósitos paleolagunares. 
Os sete tipos de alteração superficial reconhecidos durante a análise tafonômica e detalhados ao MEV-EDS não apresentam entre si grandes variações mineralógicas, sempre apresentando um ou mais dentre três componentes principais: apatita, argilomineral (provavelmente esmectita e/ou illita) e calcita (Tabela 13). Estes três componentes foram também identificados, como cimentos, na análise ao microscópio. Além deles, são ainda bastante comuns nas alterações estudadas ao MEV: matéria orgânica, seja coloidal seja na forma de filamentos, e grãos de areia aderidos.

Apatita foi encontrada apenas nas conchas de sambaquis, e dentre estas, só não foi identificada na alteração em forma de manchas pretas, que coincidentemente, corresponde à concha mais nova dentre as analisadas ao MEV-EDS. Sua formação deve-se à dissolução e reprecipitação de ossos, como também evidenciado no estudo petrográfico. Como os ossos, de acordo com esse estudo, integram o arcabouço da grande maioria das fácies de sambaquis, mesmo aquelas em que sua presença não fora notada em campo, o cimento fosfático, inclusive na forma de revestimentos de conchas, é quase ubíquo.

A apatita ocorre como massa coloidal, micrita ou microespato e a presença das formas mais bem cristalizadas aumenta com a idade da concha, frequenteente em drama drusiforme: tapete e apatita coloidal, revestido por fosfamicrita e/ou fosfamicroespato. Esta trama é indicativa de precipitação química cada vez mais lenta e, portanto, de condições de super-saturação em solutos fosfáticos, na água intersticial, cada vez menor. Isto pode ser atribuído à queda na dissolução de fosfato no tempo, seja pelo fechamento gradual dos poros pelo cimento e redução da circulação, seja por um possível aumento de pH do meio ligado à dissolução do $\mathrm{Ca}$ dos ossos e das conchas.

Calcita reprecipitada foi encontrada, na forma de micrita, em apenas duas conchas, uma paleolagunar (perda de brilho original) e outra de sambaqui (mancha preta em alto relevo). A fonte do carbonato pode ser atribuída à dissolução da própria concha ou, no caso de sambaquis, à alteração das cinzas.

Os argilominerais ocorrem sempre associados à calcimicrita ou a apatita coloidal e devem-se provavelmente à iluviação mecânica de finas partículas argilosas, incorporadas no precipitado de calcita ou apatita, nos casos em que não se distinguem seus cristais (perda de brilho original) ou à formação como cimento eodiagenético, 
nos casos em que os cristais são visíveis (crosta amarelo-alaranjada e crosta pardoamarelada). Estes últimos casos coincidem com as idades de conchas mais antigas.

Tabela 13. Composição dos tipos de alteração observados na superfície das conchas de sambaquis (AFS) e de depósitos paleolagunares (AFL).

\begin{tabular}{|c|c|c|c|}
\hline $\begin{array}{l}\text { Tipo de alteração } \\
\text { superficial }\end{array}$ & $\begin{array}{c}\text { Composição e textura da } \\
\text { alteração }\end{array}$ & $\begin{array}{l}\text { Associação de } \\
\text { fácies }\end{array}$ & $\begin{array}{l}\text { Idade da camada } \\
\text { (anos }{ }^{14} \mathrm{C} \text { cal AP) }\end{array}$ \\
\hline Crosta amarelo-alaranjada & $\begin{array}{l}\text { Esmectita-illita com rosetas } \\
\text { de gipsita e diatomáceas }\end{array}$ & AFL2 & $5660-5880$ \\
\hline $\begin{array}{l}\text { Superfície, branco-azulada, } \\
\text { sem brilho original }\end{array}$ & $\begin{array}{c}\text { Calcimicrita e } \\
\text { argilominerais, com } \\
\text { microcrateras }\end{array}$ & AFL3 & $2762-2946$ \\
\hline $\begin{array}{l}\text { Crosta marrom } \\
\text { avermelhado }\end{array}$ & $\begin{array}{l}\text { Múltiplas camadas de } \\
\text { fosfamicrita com } \\
\text { argilominerais com grãos } \\
\text { aderidos e revestimento por } \\
\text { fosfamicroespato }\end{array}$ & AFS3 & $4077-4351$ \\
\hline $\begin{array}{c}\text { Manchas pretas em alto } \\
\text { relevo }\end{array}$ & $\begin{array}{l}\text { Calcimicrita com matéria- } \\
\text { orgânica (inclusive } \\
\text { filamentos carbonosos) } \\
\text { formando faixas alongadas, } \\
\text { sinuosas (moldes de } \\
\text { radículas) com grãos } \\
\text { aderidos }\end{array}$ & AFS4 & $\begin{array}{l}2294-2459 \\
\text { (camada logo } \\
\text { abaixo) }\end{array}$ \\
\hline $\begin{array}{l}\text { Manchas amarelo- } \\
\text { alaranjadas }\end{array}$ & $\begin{array}{l}\text { Apatita coloidal e } \\
\text { argilominerais com } \\
\text { revestimento de } \\
\text { fosfamicrita }\end{array}$ & AFS3 & $\begin{array}{l}2853-3063 \\
2846-3053\end{array}$ \\
\hline Crosta pardo-amarelada & $\begin{array}{c}\text { Apatita coloidal botrioidal a } \\
\text { alveolar com revestimento } \\
\text { de fosfamicroespato; } \\
\text { esmectita-illita nas } \\
\text { depressões }\end{array}$ & AFS3 & $\begin{array}{l}4309-4532 \\
\text { (camada logo } \\
\text { abaixo) }\end{array}$ \\
\hline Crosta preta & $\begin{array}{c}\text { Apatita coloidal com } \\
\text { matéria orgânica (inclusive } \\
\text { fibras vegetais) e } \\
\text { argilominerais, com grãos } \\
\text { aderidos e revestimento de } \\
\text { fosfamicrita }\end{array}$ & AFS5 & $3632-3849$ \\
\hline
\end{tabular}

\subsection{Análise de componentes principais}

Com o intuito de fazer uma interpretação integrada dos resultados geoquímicos e isotópicos, em termos de evolução da composição das conchas ao longo do tempo e seus fatores ambientais controladores, realizou-se uma análise de componentes principais (ACP) com estes resultados. O objetivo principal foi tentar separar, até onde possível, a influência dos dois fatores ambientais distintos que supostamente atuaram para reduzir a salinidade do sistema lagunar durante o Holoceno médio e superior, quais sejam: a queda da precipitação e, portanto, do aporte fluvial; e a redução da conexão do sistema lagunar com o mar aberto. 
A ACP apontou para três componentes (Figuras 106 e 107). A componente 1 (C1) reflete a influência do $\sigma^{18} \mathrm{O}$ e do $\sigma^{13} \mathrm{C}$ e, no sentido inverso, a da razão $\mathrm{Sr} / \mathrm{Ca}$ (Figuras 106 e 107). A componente 2 (C2) expressa a influência, no mesmo sentido do sistema de coordenadas do gráfico de $\mathrm{ACP}$, de $\mathrm{Mg} / \mathrm{Ca}$ e $\mathrm{Sr} / \mathrm{Ca}$, e, no sentido oposto, de $\mathrm{Ba} / \mathrm{Ca}$ (Figura 106). Já a componente 3 (C3) expressa principalmente a variação, no mesmo sentido, de $\mathrm{Mg} / \mathrm{Ca}$ e $\mathrm{Ba} / \mathrm{Ca}$ (Figura 107). Como o objetivo da $\mathrm{ACP}$ era a evolução ambiental no tempo, as amostras de conchas foram reunidas quanto a idade, em intervalos de mil anos de duração, representados nos gráficos das figuras 106 e 107 pelos polígonos de diferentes cores.

A discussão, no subitem anterior, das figuras 82 a 86 , permite considerar os deltas ${ }^{18} \mathrm{O}$ e ${ }^{13} \mathrm{C}$ como indicadores de salinidade (influência marinha), o $\mathrm{Ba} / \mathrm{Ca}$ como indicador de presença de águas fluviais e $\mathrm{Mg} / \mathrm{Ca}$ e $\mathrm{Sr} / \mathrm{Ca}$ como geotermômetros complementares entre si, o Mg/Ca mais eficiente para o Holoceno médio e o $\mathrm{Sr} / \mathrm{Ca}$ para o Holoceno superior. Partindo destas premissas, o gráfico entre C1 e C2 (Figura 106) pode ser dividido em quatro campos: os dois campos do lado direito (o do aumento dos valores isotópicos), apontam para forte conexão marinha e os da esquerda, inversamente, para conexão marinha fraca. Já os campos superior e inferior são distintos entre si pelos valores de $\mathrm{Ba} / \mathrm{Ca}$ e portanto pela presença de águas de fonte fluvial, alta no campo inferior e baixa no superior. O gráfico mostra redução marcante e crescente da conexão marinha a partir de 3000 anos AP (lado esquerdo do eixo $x=C 1$ ). Fica evidente também o aumento de $\mathrm{Sr} / \mathrm{Ca}$ (resfriamento das águas) entre 3000 e 1000 anos AP. Os dados de ACP da Figura 106 mostram redução de influência fluvial de 3-2 ka AP para 2-1 ka AP, época de pouca variação de precipitação em Santa Catarina segundo Bernal et al. (2016). Isto sugere que, pelo menos no Holoceno superior, a influência do aporte continental foi mais controlada pelo processo progressivo de fechamento da laguna (aumento na proporção água doce / água marinha) que de variação na precipitação e, portanto, da vazão fluvial. 


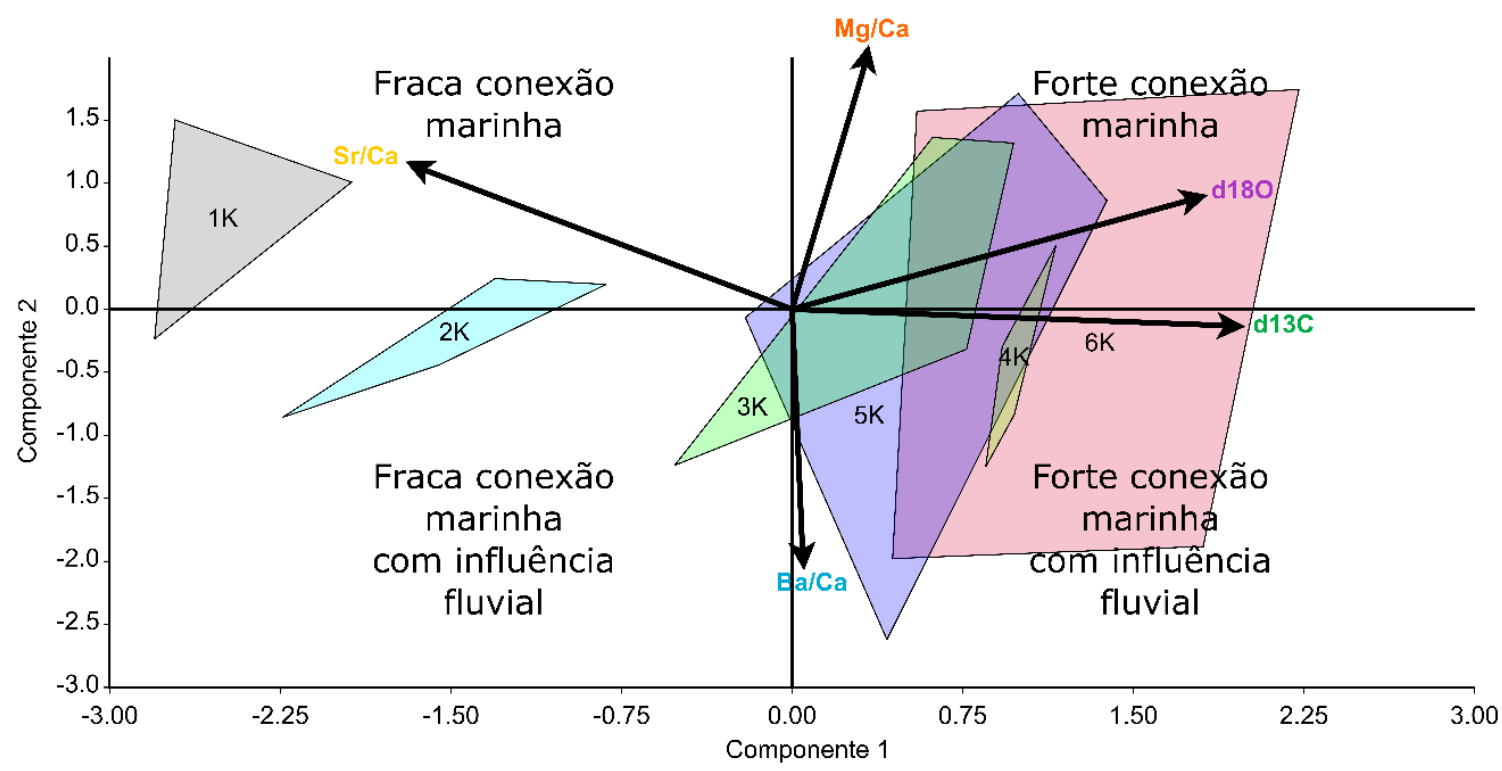

Figura 106. Análise de componentes principais: componente 1 (mais influenciado por $\sigma^{18} \mathrm{O}$ e $\sigma^{13} \mathrm{C}$ e, inversamente, por $\mathrm{Sr} / \mathrm{Ca}$ ) versus componente 2 (mais influenciado inversamente por $\mathrm{Ba} / \mathrm{Ca}$ e $\mathrm{Mg} / \mathrm{Ca}$ ). Os polígonos coloridos indicam agrupamentos de conchas por idade ( $\mathrm{k}=$ milhares de anos).

Já o gráfico C1 x C3 (Figura 107) tem a vantagem de separar melhor, entre si, cinco dos seis intervalos de tempo analisados e, desse modo, ligar os quatro quadrantes a fases sucessivas de evolução sedimentar. O intervalo de 7 a 6 ka (direita inferior) corresponde a conexão marinha forte (razões isotópicas altas), mas com pouca influência fluvial ( $\mathrm{Ba} / \mathrm{Ca}$ baixo), o que é o esperado na fase evolutiva de baía aberta. O intervalo de 6 a 3 ka (direita superior) corresponde a conexão marinha forte, mas com influência fluvial, situação típica de laguna com desembocadura bastante aberta. Os dois intervalos milenares seguintes (lado esquerdo) são de conexão marinha fraca, indicativa de laguna relativamente mais fechada. A conexão marinha é menor no intervalo de 2 a 1 ka (triângulo cinza mais à esquerda) que no de 3 a $2 \mathrm{ka}$, mas com influência do aporte fluvial (eixo y) apenas ligeiramente maior. Este gráfico demonstra que, na fase de laguna aberta, não há evidências de variação de influência fluvial entre 6 e $3 \mathrm{ka}$, portanto antes e depois do pico de precipitação regional (4ka). Este é mais um indício de que a precipitação não teria sido o principal fator controlador da presença/influência de águas continentais, a qual se deveu, portanto, sobretudo, ao fechamento progressivo da conexão entre laguna e mar aberto. 


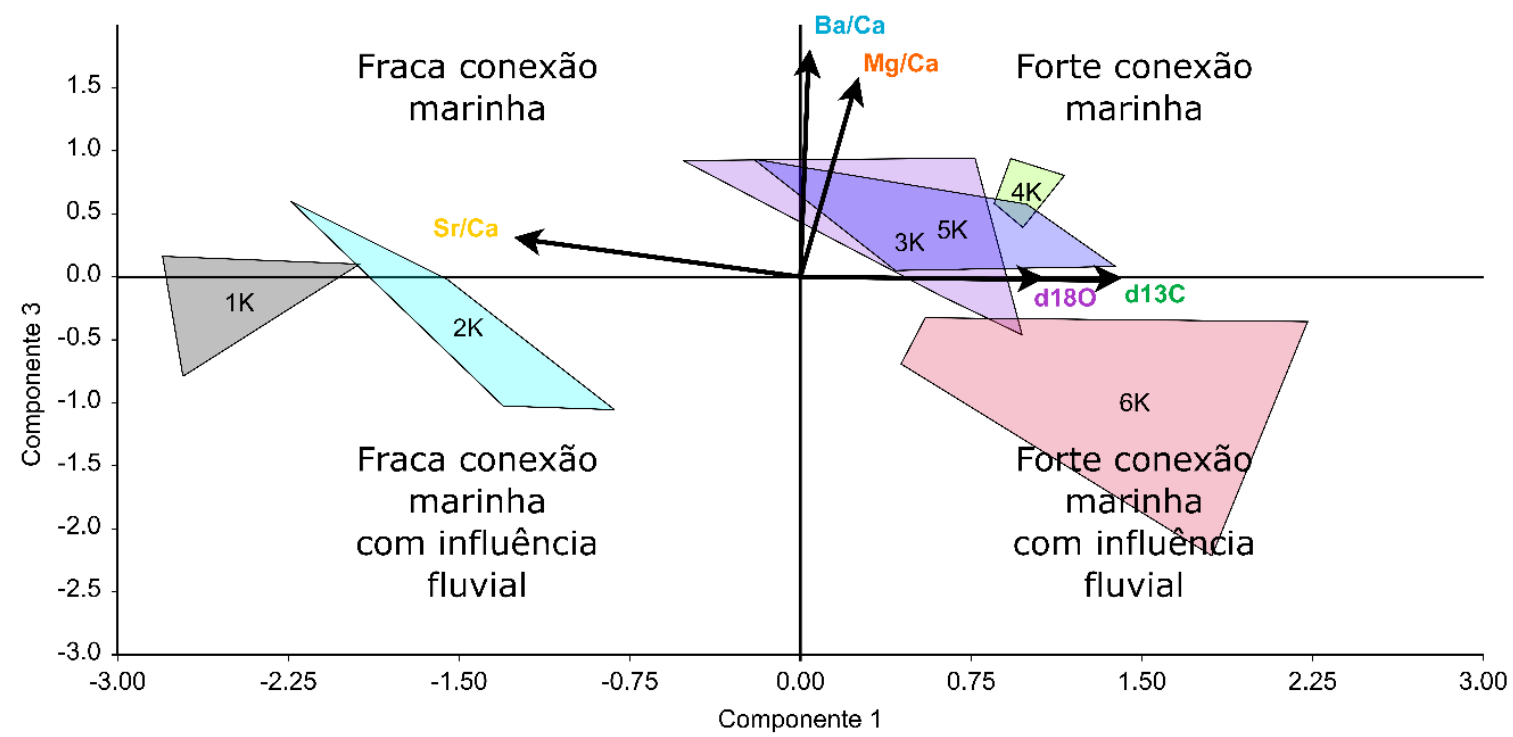

Figura 107. Análise de componentes principais: componente 1 (mais influenciado por $\sigma^{18} \mathrm{O}$ e $\sigma^{13} \mathrm{C}$ e, inversamente, por $\mathrm{Sr} / \mathrm{Ca}$ ) versus componente 3 (mais influenciado por $\mathrm{Ba} / \mathrm{Ca}$ e $\mathrm{Mg} / \mathrm{Ca}$ ). Os polígonos coloridos indicam agrupamentos de conchas por idade ( $\mathrm{k}=$ milhares de anos). 


\section{CONCLUSÕES}

1. As conchas inteiras e não desgastadas dos sambaquis são, na maior parte dos casos, contemporâneas às fogueiras e, portanto, contemporâneas à ocupação. Isto significa que elas eram extraídas do fundo lagunar ativo na época da ocupação e não de depósitos naturais ou arqueológicos preexistentes (séculos mais antigos).

2. A principal exceção é o sambaqui Perrixil que apresenta inversões estratigráficas marcantes e carvão mais novo do que conchas, denotando que, neste caso, a escolha da matéria-prima conchífera recaiu sobre material retrabalhado até cerca de 500 anos mais velho, ou do fundo da laguna ou de depósito arqueológico preexistente.

3. O sambaqui Perrixil é o de posição mais a norte e também o que contém as conchas com idades mais jovens dentre os estudados. Em vista disso, o fato de ele possuir aparentemente um processo de construção diferenciado em relação aos demais permite cogitar que houve mudança no tempo, ou no espaço (do sul para o norte da área), nas estratégias de construção do depósito arqueológico.

4. De modo geral, os sambaquis apresentam menor grau de mistura temporal que os depósitos paleolagunares, mas esta diferença pode ter sido influenciada pelo método de amostragem, que foi estratigraficamente mais preciso no sambaqui de que nos concheiros naturais.

5. A escolha mais frequente feita no processo de construção de cada camada/fácies dos sambaquis refere-se a quantidade de conchas na fração cascalho versus quantidade de sedimento mais fino, o que se reflete na interestratificação de grande variedade de fácies; embora parte da fração pelítica de certas fácies do sambaqui possa vir dos sedimentos paleolagunares, os teores máximos de fração pelítica muito mais elevados nos sambaquis de que nas paleolagunas indicam que parcela significativa desta fração fina deriva de produtos de alteração eodiagenética de conchas, ossos finamente moídos e matéria orgânica, e de cinzas, como demonstrado na petrografia pela presença marcante de cimento calci e fosfamicrítico.

6. Em comparação com os depósitos paleolagunares naturais, os sambaquis apresentam maior variabilidade de tamanho médio de grão e de desvio padrão 
e assimetria da distribuição granulométrica, o que reflete a maior diversidade de fácies encontrada e amostrada nos depósitos arqueológicos e as grandes variações nos seus teores de pelíticos e de cascalho conchífero.

7. A assinatura tafonômica "dissolução" correlaciona-se com a "fragmentação", provavelmente porque a fragmentação favorece o aumento da superfície específica das conchas, e, portanto, a sua maior exposição à ação reativa das águas intersticiais.

8. A presença marcante do bivalve Anomalocardia brasiliana nos sambaquis reflete a enorme disponibilidade deste molusco em seu meio natural, já que este é também o táxon de invertebrado mais abundante nos sedimentos paleolagunares.

9. A análise de fácies nas diferentes seções verticais permitiu identificar sucessões preferenciais ou padrões recorrentes de empilhamento (associações de fácies), mais evidentes nos depósitos de paleolagunas e paleobaías, cujas fácies são menos diversificadas, mas presentes também nos sambaquis.

10. Tanto nas paleolagunas quanto nos sambaquis, associações de fácies dominadas por conchas inteiras são mais comuns nos depósitos mais antigos, sobretudo anteriores a $3 \mathrm{ka}$, de que nos mais novos. Isto reflete a queda de disponibilidade de $A$. brasiliana, bem como o encolhimento dos bancos de moluscos, seja pelo progressivo assoreamento do sistema lagunar, seja pelo aparecimento de condições ecológicas desfavoráveis, como queda de salinidade das águas e aumento no material em suspensão, este último devido à aproximação do delta do rio Tubarão.

11. A salinidade é o principal fator ambiental determinante dos valores de $\delta^{18} \mathrm{O}$ nas conchas de $A$. brasiliana na região.

12. Os dois maiores picos de elevação do $\delta^{18} \mathrm{O}$, o principal deles em cerca de 5,2 ka atrás e o subordinado em $7 \mathrm{ka}$, coincidem com os momentos de máximo NRM e de máxima inundação, respectivamente, e estão ligados, portanto, a aumento da influência marinha nas antigas lagunas ou baías.

13. O pico mais acentuado de queda do $\delta^{18} \mathrm{O}$, encontrado em torno de $1,5 \mathrm{ka} A P$, coincide com um evento Bond, quando a precipitação e, por consequência, o aporte de água doce no sistema lagunar podem ter aumentado. Alternativamente, pode-se atribuir este pico negativo a fatores autogênicos 
capazes de elevar o suprimento de águas fluviais nos setores lagunares amostrados neste trabalho, por exemplo, mudança de posição dos distributários ativos do delta do rio Tubarão.

14. A tendência de queda dos valores medianos de $\delta^{18} \mathrm{O}$ no período de $7,0 \mathrm{ka}$ a 5,5 ka AP pode significar o aumento no aporte de água doce, apesar da elevação do NRM. Isto pode relacionar-se à elevação da precipitação ou à então recente formação da barreira arenosa, a leste, que transformou a baía semiaberta em uma laguna, mais fechada e com maior retenção das águas continentais.

15. O segundo período de queda de $\delta^{18} \mathrm{O}$, entre a época do máximo NRM e 1,5 ka AP, associa-se ao fechamento cada vez maior do sistema lagunar, por conta de seu assoreamento e da rápida progradação da costa, agora sob NRM em queda.

16. Os valores médios encontrados em conchas de $A$. brasiliana viventes na região são ainda mais negativos que os valores medianos da curva de variação apresentada entre 7 e 1,5 ka, sugerindo que o aumento progressivo da influência de água doce, detectado nas conchas fósseis, segue até os dias atuais.

17. A correlação linear direta entre $\delta^{13} \mathrm{C}$ e $\delta^{18} \mathrm{O}$, incluindo similaridades nos picos em 7ka e da época de máximo NRM e na tendência de queda dos valores medianos no decorrer do tempo, permite sugerir que ambas as razões sejam controladas por mesmos fatores, ou seja, precipitação e paleogeografia, os quais determinam o grau de mistura entre águas continentais e marinhas.

18. A elevação de $\mathrm{Mg} / \mathrm{Ca}$ entre 6 e 5 ka pode ser atribuída ao aumento da temperatura da água do sistema lagunar, possivelmente por influência do aquecimento das águas do mar, nesse período.

19. O aumento de $\mathrm{Sr} / \mathrm{Ca}$ das conchas de $A$. brasiliana ao longo do Holoceno superior é sugestivo de declínio de temperatura das águas lagunares, com possível influência de resfriamento das águas costeiras, nesse período.

20. A elevação da razão $\mathrm{Ba} / \mathrm{Ca}$ das conchas ao longo do Holoceno superior é um indicativo de aumento da diluição das águas marinhas pelas continentais dentro do sistema lagunar, seja por aumento de precipitação seja por fechamento 
progressivo da conexão da laguna com o mar, sob condição de NRM declinante.

21. A distribuição de amostras de conchas de diferentes idades, em diagramas de análise de componentes principais baseados nos dados geoquímicos e isotópicos, e o confronto destes resultados com curvas de variação do nível relativo do mar e de paleoprecipitação para a região, permitem sugerir que o fechamento da conexão da laguna com mar aberto foi mais importante que a queda de precipitação no processo de redução de salinidade das águas lagunares onde $A$. brasiliana vivia. 


\section{REFERÊNCIAS BIBLIOGRÁFICAS}

Addadi, L., Joester, D., Nudelman, F., \& Weiner, S. 2006. Mollusk shell formation: a source of new concepts for understanding biomineralization processes. Chemistry-A European Journal, 12(4), 980-987.

Alibert, C., and McCulloch, M.T., 1997, Strontium/calcium ratios in modern porites corals From the Great Barrier Reef as a proxy for sea surface temperature: Calibration of the thermometer and monitoring of ENSO: Paleoceanography, v. 12, p. 345-363, doi:10.1029/97PA00318.

Amaral, P.G.C. do, 2008, Evolução da sedimentação lagunar holocênica na região de Jaguaruna, Estado de Santa Catarina: uma abordagem sedimentológicamicropaleontológica integrada: Universidade de São Paulo, doi:10.11606/T.44.2008.tde$19122008-160829$.

Amaral, P.G.C., Giannini, P.C.F, Sylvestre, F., Pessenda, L.C.R., 2012, Paleoenvironmental reconstruction of a Late Quaternary lagoon system in southern Brazil (Jaguaruna region, Santa Catarina state) based on multi-proxy analysis: Journal of Quaternary Science, v. 27, p. 181-191, doi:10.1002/jqs. 1531.

Amiel, A. J., Miller, D. S., \& Friedman, G. M. 1973. Incorporation of uranium in modern corals. Sedimentology, 20(4), 523-528.

Angulo, R.J., Giannini, P.C.F., 1993, Variação do nível relativo do mar nos últimos dois mil anos na região sul do Brasil: uma discussão: Boletim Paranaense de Geociências, v. 44, p. 67-75.

Angulo, R.J., Souza, M.C. 2014. Revisão conceitual de indicadores costeiros de paleoníveis marinhos quaternários no Brasil. Quaternary and Environmental Geosciences, 5(2): -132.

Angulo, R.J., Giannini, P.C.., Suguio, K., and Pessenda, L.C.., 1999, Relative sea-level changes in the last 5500 years in southern Brazil (Laguna-Imbituba region, Santa Catarina State) based on vermetid ages: Marine Geology, v. 159, p. 323-339, doi:10.1016/S0025-3227(98)00204-7.

Angulo, R.J., Souza, M.C., Reimer, P.J., Sasaoka, S.K. 2005. Reservoir effect of the southern and southeastern Brazilian coast: Radiocarbon, v. 47, p. 67-73.

Angulo, R.J., Lessa, G., Souza, M., 2006, A critical review of mid- to late-Holocene sea-level fluctuations on the eastern Brazilian coastline: Quaternary Science Reviews, v. 25, p. 486-506, doi:10.1016/j.quascirev.2005.03.008.

Assunção, D. C. (2010). Sambaquis da paleolaguna de Santa Marta: em busca do contexto regional no litoral sul de Santa Catarina. Dissertação de mestrado, MAE-Universidade de São Paulo.

Barreira, C.A.R. e Araújo, M.L.., 2005, NoCiclo reprodutivo de Anomalocardia brasiliana (Gmelin, 1791) (Mollusca, Bivalvia, Veneridae) na Praia do Canto da Barra, Fortim, Ceará, Brasil Title: Boletim do Instituto de Pesca, São Paulo, v. 31, p. 9-20.

Beck, J.W., Edwards, R.L., Ito, E., Taylor, F.W., Recy, J., Rougerie, F., Joannot, P., and Henin, C., 1992, Sea-Surface Temperature from Coral Skeletal Strontium/Calcium Ratios: Science, v. 257, p. 644-647, doi:10.1126/science.257.5070.644.

Behrensmeyer, A.K., and Kidwell, S.M., 1985, Taphonomy's contributions to paleobiology: Paleobiology, v. 11, p. 105-119, doi:10.1017/S009483730001143X.

BendazzoLi, C. (2007). O processo de formação dos sambaquis: uma leitura estratigráfica do sítio Jabuticabeira II (Doctoral dissertation, Dissertação de Mestrado. São Paulo, Universidade de são paulo. 246pp. 
Bernal, J. P., Cruz, F. W., Stríkis, N. M., Wang, X., Deininger, M., Catunda, M. C. A., ... Auler, A. S. 2016. High-resolution Holocene South American monsoon history recorded by a speleothem from Botuverá Cave, Brazil. Earth and Planetary Science Letters, 450, 186196.

Bernat, M.; Martin, L.; Bittencourt, A.C.S.P.; Vilas-Boas, G.S. 1983. Datation Io/U du plus haut niveau marin interglaciaire sur la côte du Brésil: utilisation du 229Th comme traceur. Comptes Rendus de l'Ácademie de Sciences de Paris, 296: 197-200.

Best, M. M., \& Kidwell, S. M. 2000a. Bivalve taphonomy in tropical mixed siliciclastic-carbonate settings. I. Environmental variation in shell condition. Paleobiology, 26(1), 80-102.

Best, M. M., \& Kidwell, S. M. 2000b. Bivalve taphonomy in tropical mixed siliciclastic-carbonate settings. II. Effect of bivalve life habits and shell types. Paleobiology, 26(1), 103-115.

Bigarella, J.J., Klein, R.M., Lange, R.B., Loyola E Silva, J., Larach, J.O.I. e Rauen, M.., 1978, A Serra do Mar e a Porção Oriental do Estado do ParanáNo Title: Curitiba: Secretaria do Planejamento, Governo do Estado do Paraná, p. 249p.

Boehs, G., Absher, T.M., Cruz-Kaled, A.., 2008, No TitlEcologia populacional de Anomalocardia brasiliana (Gmelin, 1791) (Bivalvia, Veneridae) na Baía de Paranaguá, Paraná, Brasile: Boletim do Instituto de Pesca, v. 34, p. 259-270.

Bond, G., Showers, W., Cheseby, M., Lotti, R., Almasi, P., DeMenocal, P., ... \& Bonani, G. 1997. A pervasive millennial-scale cycle in North Atlantic Holocene and glacial climates. science, 278(5341), 1257-1266.

Boyle, E.A., Sclater, F., and Edmond, J.M., 1976, On the marine geochemistry of cadmium: Nature, v. 263, p. 42-44, doi:10.1038/263042a0.

Brett, C.E., Baird, G.C., 1986, Comparative Taphonomy: A Key to Paleoenvironmental Interpretation Based on Fossil Preservation: PALAIOS, v. 1, p. 207, doi:10.2307/3514686.

Carré, M., Bentaleb, I., Blamart, D., Ogle, N., Cardenas, F., Zevallos, S., Kalin, R.M., Ortlieb, L., and Fontugne, M., 2005, Stable isotopes and sclerochronology of the bivalve Mesodesma donacium: Potential application to Peruvian paleoceanographic reconstructions: Palaeogeography, Palaeoclimatology, Palaeoecology, v. 228, p. 4-25, doi:10.1016/j.palaeo.2005.03.045.

Chan, L.H., Drummond, D., Edmond, J.M., and Grant, B., 1977, On the barium data from the Atlantic GEOSECS expedition: Deep Sea Research, v. 24, p. 613-649, doi:10.1016/0146-6291(77)90505-7.

Chave, K.E., 1954, Aspects of the Biogeochemistry of Magnesium 1. Calcareous Marine Organisms: The Journal of Geology, v. 62, p. 266-283, doi:10.1086/626162.

Cleve, P. T. (1873). On diatoms from the Arctic Sea (Vol. 1, No. 13). PA Norstedt.

Colonese, A.C. et al., 2017, Shell sclerochronology and stable isotopes of the bivalve Anomalocardia flexuosa (Linnaeus, 1767) from southern Brazil: Implications for environmental and archaeological studies: Palaeogeography, Palaeoclimatology, Palaeoecology, v. 484, p. 7-21, doi:10.1016/j.palaeo.2017.01.006.

Conroy, J. L., Overpeck, J. T., \& Cole, J. E. 2010. El Niño/Southern Oscillation and changes in the zonal gradient of tropical Pacific sea surface temperature over the last 1.2 ka. PAGES news, 18(1), 32-34.

Craig, H., 1953, The geochemistry of the stable carbon isotopes: Geochimica et Cosmochimica Acta, v. 3, p. 53-92, doi:10.1016/0016-7037(53)90001-5.

Cruz, F.W., Burns, S.J., Karmann, I., Sharp, W.D., and Vuille, M., 2006, Reconstruction of regional atmospheric circulation features during the late Pleistocene in subtropical Brazil 
from oxygen isotope composition of speleothems: Earth and Planetary Science Letters, v. 248, p. 495-507, doi:10.1016/j.epsl.2006.06.019.

Davies, D.J., Powell, E.N., and Stanton, R.J., 1989, Taphonomic signature as a function of environmental process: Shells and shell beds in a hurricane-influenced inlet on the Texas coast: Palaeogeography, Palaeoclimatology, Palaeoecology, v. 72, p. 317-356, doi:10.1016/0031-0182(89)90150-8.

DeBlasis, P., Afonso, M.C., Figuti, L., Fish, P., Fish, S., Gaspar, M.D., Eggers, S., and Lahr, M.M., 1998, Padrões de assentamento e formação de sambaquis em Santa Catarina: Revista do Museu de Arqueologia e Etnologia, p. 319, doi:10.11606/issn.24481750.revmae.1998.109563.

DeBlasis, P., Kneip, A., Scheel-Ybert, R., Giannini, P.C.F., Gaspar, M., 2007, Sambaquis e paisagem: dinâmica natural e arqueologia regional no litoral do sul do Brasil: Arqueologia Sul-Americana, v. 3, p. 29-61.

Efremov, I., 1940, Taphonomy: new branch of Paleontology: Pan-American Geologist, v. LXXIV, p. 81-93.

Epstein, S., Buchsbaum, R., Lowenstam, H., Urey, H., 1951, Carbonate-water isotopic temperature scaleNo Title: Bulletin of the Geological Society of America, v. 62, p. 417426.

Erthal, F. (2012). Assinaturas tafonômicas em bibalves marinhos recentes na costa do Brasil e seu significado paleoambiental. Tese de doutorado. UFRGS. Porto Alegre.

Denys, L. (1994). Diatom assemblages along a former intertidal gradient: A palaeoecological study of a subboreal clay layer (Western coastal plain, Belgium). Netherland Journal of Aquatic Ecology, 28(1), 85-96.

Fish, S. K., DeBlasis, P., Gaspar, M. D., \& Fish, P. R. (2000). Eventos incrementais na construção de sambaquis, litoral sul do Estado de Santa Catarina. Revista do Museu de Arqueologia e Etnologia, 10, 69-87.

Folk, R. L. 1954. The distinction between grain size and mineral composition in sedimentaryrock nomenclature. The Journal of Geology, 62(4), 344-359.

Folk, R. L. 1968. Petrology of sedimentary rocks. Hemphill Publishing Company.

Folk, R.L.; Land, L.S. 1975. Mg/Ca ratio and salinity: two controls over the crystallization of dolomite. Am. Assoc. Petrol. Geol., 59: 60-68.

Fornari, M., 2010, Evolução sedimentar holocênica da retrobarreira na região de JaguarunaLaguna, Santa Catarina, Brasil: Universidade de São Paulo, doi:10.11606/T.44.2010.tde$24012011-114334$.

Fornari, M., Giannini, P.C.F., Amaral, P.G.C., Nascimento Jr., D.R., Menezes, P.M.L.; Sawakuchi, A.O., Angulo, R.J., Pessenda, L.C.., 2008, Composição isotópica ( $\delta 180$ e $\delta 13 C$ ) e idades $14 \mathrm{C}$ de carapaças de Anomalocardia brasiliana e Petaloconchus varians no Holoceno da costa de Santa Catarina, Sul do Brasil., in CONGRESSO DE GEOQUÍMICA DOS PAÍSES DE LÍNGUA PORTUGUESA, 9., 2008, Cabo Verde. Anais... Cabo Verde: Universidade de Cabo Verde.

Fornari, M., Giannini, P.C.F., Nascimento, D.R., 2012, Facies associations and controls on the evolution from a coastal bay to a lagoon system, Santa Catarina Coast, Brazil: Marine Geology, v. 323-325, p. 56-68, doi:10.1016/j.margeo.2012.07.010.

Garreaud, R.D., Vuille, M., Compagnucci, R., Marengo, J., 2009. Present-day South American climate. Palaeogeography, Palaeoclimatology, Palaeoecology 281, 180e195.

Gaspar, M., 2002, Padrão de assentamento e formação de sambaquis: arqueologia e preservação em Santa Catarina: Revista de Arqueologia do IPHAN, v. 1, p. 57-62. 
Giannini, P.C.F. 1993. Sistemas deposicionais no quaternário costeiro entre Jaguaruna e Imbituba, SC. Tese de doutorado. Universidade de São Paulo.

Giannini, P.C.F. 2002. Complexo lagunar centro-sul catarinense-valioso patrimônio sedimentológico, arqueológico e histórico. Sítios geológicos e paleontológicos do Brasil, 75, 213-222.

Giannini, P.C.F., Deblasis, P., Sawakuchi, A.O., Amaral, P.G.., 2005, Processos e materiais geológicos e a construção de sambaquis no litoral sul de Santa Catarina: Congresso da Abequa, Guarapari - ES. Boletim de resumos, p. 196.

Giannini, P.C.F., Sawakuchi, A.O., Martinho, C.T., and Tatumi, S.H., 2007, Eolian depositional episodes controlled by Late Quaternary relative sea level changes on the ImbitubaLaguna coast (southern Brazil): Marine Geology, v. 237, p. 143-168, doi:10.1016/j.margeo.2006.10.027.

Giannini, P.C.F., Menezes, P.M.L., Deblasis, P., 2009, Sucessões de fácies e arquitetura deposicional no sambaqui Jabuticabeira II (Jaguaruna, Estado de Santa Catarina), litoral da Região Sul do Brasil: CONGRESSO DA ASSOCIAÇÃO BRASILEIRA DE ESTUDOS DO QUATERNÁRIO, v. 12.

Giannini, P.C.F., Villagran, X.S., Fornari, M., Nascimento Junior, D.R. do, Menezes, P.M.L., Tanaka, A.P.B., Assunção, D.C., DeBlasis, P., Amaral, P.G.C. do, 2010, Interações entre evolução sedimentar e ocupação humana pré-histórica na costa centro-sul de Santa Catarina, Brasil: Boletim do Museu Paraense Emílio Goeldi. Ciências Humanas, v. 5, p. 105-128, doi:10.1590/S1981-81222010000100008.

Gillikin, D. P., Lorrain, A., Navez, J., Taylor, J. W., André, L., Keppens, E., ... \& Dehairs, F. (2005). Strong biological controls on $\mathrm{Sr} / \mathrm{Ca}$ ratios in aragonitic marine bivalve shells. Geochemistry, Geophysics, Geosystems, 6(5).

Gordillo, S., Bayer, M. S., Boretto, G., \& Charó, M. (2014). Mollusk shells as bio-geo-archives: Evaluating environmental changes during the Quaternary. Springer Science \& Business Media.

Hall, J.M., 2002, Barium and Lithium in Foraminifera: glacial-interglacial changes in the North Atlantic. PhD. Thesis, Louisiana State University: $131 \mathrm{p}$.

Hiroki, K. 1977. On the resistance of isolated bivalve gill pieces to oxygen deficiency and hydrogen sulphide. Bolm: Fisiol. Animal Univ. S. Paulo, São Paulo, v. 1, p. 9-20.

Holz, M., Simões, M.., 2002, Elementos Fundamentais de Tafonomia. Editora da Universidade/ UFRGS: $231 \mathrm{p}$.

Jiang, H., Björck, S., \& Knudsen, K. L. (1997). A palaeoclimatic and palaeoceanographic record of the last $1100014 \mathrm{C}$ years from the Skagerrak-Kattegat, northeastern Atlantic margin. The Holocene, 7(3), 301-310.

Karl, R. (2000). The Relative Chronology of Cultural Episodes at the Coastal Sambaqui, Jabuticabeira II. Santa Catarina. University of Arizona, Brazil.

Kidwell, S.M. Fürshich, F.T., Aigner, T. 1986. Conceptual framework for the analysis and classification of fossil concentrations. Palaios, 1, 228-238.

Kidwell, S.M., Rothfus, T.A., Best, M.M. 2001. Sensitivity of taphonomic signatures to sample size, sieve size, damage scoring system, and target taxa. Palaios, 16(1), 26-52.

Kinsman, D.J.J., Holland, H., 1969, The co-precipitation of cations with CaCO3: Geochim Cosmochim Acta, v. 33, p. 1-17.

Köppen, W. 1948. Climatologia. México. Fundo de Cultura Econômica. 
Klein, R.T., Lohmann, K.C., Thayer, C.W., 1996, Bivalve skeletons record sea-surface temperature and $\delta 180$ via $\mathrm{Mg} / \mathrm{Ca}$ and $18 \mathrm{O} / 16 \mathrm{O}$ ratios: Geology, v. 24, p. 415, doi:10.1130/0091-7613(1996)024<0415:BSRSST>2.3.CO;2.

Lea, D., and Boyle, E., 1989, Barium content of benthic foraminifera controlled by bottom-water composition: Nature, v. 338, p. 751-753, doi:10.1038/338751a0.

Leonel, R.M.V.; Magalhães, A.R.M. Lunetta, J.., 1983, Sobrevivência de Anomalocardia brasiliana (Gmelin, 1791) (Mollusca: Bivalvia), em diferentes salinidades: Bolm. Fisiol. Animal Univ. S. Paulo, São Paulo, v. 7, p. 63-72.

Lessa, A., \& Medeiros, J. D. (2001). Reflexões preliminares sobre a questão da violência em populações construtoras de sambaquis: análise dos sítios Cabeçuda (SC) e Arapuan (RJ). Revista do Museu de Arqueologia e Etnologia, 11, 77-93.

McCulloch, M., Cappo, M., Aumend, J., \& Müller, W. (2005). Tracing the life history of individual barramundi using laser ablation MC-ICP-MS Sr-isotopic and $\mathrm{Sr} / \mathrm{Ba}$ ratios in otoliths. Marine and Freshwater Research, 56(5), 637-644.

McQuoid, M. R., \& Nordberg, K. (2003). The diatom Paralia sulcata as an environmental indicator species in coastal sediments. Estuarine, Coastal and Shelf Science, 56(2), 339354.

Marin, F., Le Roy, N., \& Marie, B. (2012). The formation and mineralization of mollusk shell. Front Biosci, 4(1099), 125.

Martin, J.-M., Meybeck, M., 1979, Elemental mass-balance of material carried by major world rivers: Marine Chemistry, v. 7, p. 173-206, doi:10.1016/0304-4203(79)90039-2.

Martin, L.; Suguio, K.; Flexor, J.M.; Azevedo, A.E.., 1988, Mapa Geológico do Quaternário Costeiro dos Estados do Paraná e Santa Catarina. Brasília: DNPM 2 mapas (Série Geologia 28, Seção Geologia Básica 18), v. 28, p. 40.

Mendes, V. R., Giannini, P. C. F., Guedes, C. C. F., DeWitt, R., \& Andrade, H. A. D. A. 2015. Central Santa Catarina coastal dunefields chronology and their relation to relative sea level and climatic changes. Brazilian Journal of Geology, 45, 79-95.

Menezes, P.M.L., 2009, Análise de fácies e proveniência sedimentar em sambaquis do litoral centro-sul de Santa Catarina: Universidade de São Paulo, doi:10.11606/D.44.2009.tde19082009-102541.

Monti, D., Frenkiel, L., Moueza, M., 1991, DEMOGRAPHY AND GROWTH OF ANOMALOCARDIA BRASILIANA (GMELIN) (BIVALVIA: VENERIDAE) IN A MANGROVE, IN GUADELOUPE (FRENCH WEST INDIES): Journal of Molluscan Studies, v. 57, p. 249-257, doi:10.1093/mollus/57.2.249.

Mook, W. G. 1971. Paleotemperatures and chlorinities from stable carbon and oxygen isotopes in shell carbonate. Palaeogeography, Palaeoclimatology, Palaeoecology, 9(4), 245-263.

Moreira Filho, H., Moreira, I. M. V., \& Mosimann, R. M. S. 1985. Catálogo das diatomáceas (Chrysophyta-Bacillariophyceae) marinhas e estuarinas do estado de Santa Catarina, Brasil. INSULA Revista de Botânica, 15, 33.

Mosimann, R. M. S. (1988). Estudo preliminar das diatomáceas (ChrysophytaBacillariophyceae) da Baia Sul, Florianópolis, Santa Catarina-Brasil. INSULA Revista de Botânica, 18, 23.

Moy, C. M., Seltzer, G. O., Rodbell, D. T., \& Anderson, D. M. (2002). Variability of El Niño/Southern Oscillation activity at millennial timescales during the Holocene epoch. Nature, 420(6912), 162.

Narchi, W., 1974, Aspectos ecológicos e adaptativos de alguns bivalves do litoral paulista: Papéis Avulsos Zool., São Paulo, v. 27, p. 235-262. 
Nascimento Junior, D.R. do, 2011, Evolução sedimentar holocênica do delta do rio Tubarão, Estado de Santa Catarina: Universidade de São Paulo, doi:10.11606/T.44.2011.tde26072011-145300.

Orselli, J. (1986). Climatologia. GAPLAN-SC. Atlas de Santa Catarina, 38-39.

Pereira, L.G. 2016. Análise tafonômica de alta resolução de concentrações fossilíferas (shell beds) dos depósitos sedimentares holocênicos da região entre Jaguaruna e Laguna, Santa Catarina. Monografia de trabalho de formatura. IGc-USP.

Popov, S. V. (2014). Formation of bivalve shells and their microstructure. Paleontological Journal, 48(14), 1519-1531.

Poulain, C., Gillikin, D. P., Thébault, J., Munaron, J. M., Bohn, M., Robert, R., ... \& Lorrain, A. (2015). An evaluation of $\mathrm{Mg} / \mathrm{Ca}, \mathrm{Sr} / \mathrm{Ca}$, and $\mathrm{Ba} / \mathrm{Ca}$ ratios as environmental proxies in aragonite bivalve shells. Chemical Geology, 396, 42-50.

Raddatz, J., Liebetrau, V., Rüggeberg, A., Hathorne, E., Krabbenhöft, A., Eisenhauer, A., ... \& Freiwald, A. (2013). Stable Sr-isotope, $\mathrm{Sr} / \mathrm{Ca}, \mathrm{Mg} / \mathrm{Ca}, \mathrm{Li} / \mathrm{Ca}$ and $\mathrm{Mg} / \mathrm{Li}$ ratios in the scleractinian cold-water coral Lophelia pertusa. Chemical geology, 352, 143-152.

Ravelo, A. C., \& Hillaire-Marcel, C. (2007). The use of oxygen and carbon isotopes of foraminifera in paleoceanography. Developments in marine geology, 1, 735-764.

Regev, L., Eckmeier, E., Mintz, E., Weiner, S., \& Boaretto, E. (2011). Radiocarbon concentrations of wood ash calcite: potential for dating. Radiocarbon, 53(1), 117-127.

Ritter, M.N., Erthal, F., \& Coimbra, J. C. (2013). Taphonomic signatures in molluscan fossil assemblages from the Holocene lagoon system in the northern part of the coastal plain, Rio Grande do Sul State, Brazil. Quaternary International, 305, 5-14.

Rodrigues, A., Borges-Azevedo, C., Costa, R., and Henry-Silva, G., 2013, Population structure of the bivalve Anomalocardia brasiliana, (Gmelin, 1791) in the semi-arid estuarine region of northeastern Brazil: Brazilian Journal of Biology, v. 73, p. 819-833, doi:10.1590/S151969842013000400019.

Rosenthal, Y., Boyle, E.A., and Slowey, N., 1997, Temperature control on the incorporation of magnesium, strontium, fluorine, and cadmium into benthic foraminiferal shells from Little Bahama Bank: Prospects for thermocline paleoceanography: Geochimica et Cosmochimica Acta, v. 61, p. 3633-3643, doi:10.1016/S0016-7037(97)00181-6.

Rossi, P., 1992, Os sinais do tempo: história da Terra e história das nações de Hooke a Vico. Trad. Julia Mainardi. São Paulo. Companhia das Letras: 387 p.

Schaeffer-Novelli, Y., 1980, Análise populacional de Anomalocardia brasiliana (Gmelin, 1791), na Praia do Saco da Ribeira, Ubatuba, Estado de São Paulo: Boletim do Instituto Oceanográfico, v. 29, p. 351-355, doi:10.1590/S0373-55241980000200070.

Schöne, B. R. (2008). The curse of physiology-challenges and opportunities in the interpretation of geochemical data from mollusk shells. Geo-Marine Letters, 28(5-6), 269285.

Schöne, B. R., Oschmann, W., Rössler, J., Castro, A. D. F., Houk, S. D., Kröncke, I., ... \& Dunca, E. (2003). North Atlantic Oscillation dynamics recorded in shells of a long-lived bivalve mollusk. Geology, 31(12), 1037-1040.

Seilacher, A., 1970, Begriff Und Bedeutung der Fossil-Lagerstätten: Neues Jahrbuch für geologie und Palãontologie, Jahrgang, v. Heft 1, p. 34-39.

Simões, M.G., Ghilardi, R.P. 2000. Protocolo tafononômico/paleoautoecológico como ferramenta na análise paleossinecológica: Pesquisas em Geociências, 27 (2): p. 313.Smith, S. V., Buddemeier, R.W., Redalje, R.C., Houck, J.E., 1979, Strontium-Calcium 
Thermometry in Coral Skeletons: Science, v. 204, p. 404-407, doi:10.1126/science.204.4391.404.

Souza, R.C.C.L., Silva, E.P., Andrade Lima, T., 256AD, Conchas marinhas de sambaquis do Brasil. Technical Books: 2011 p.

Speyer, S.E., and Brett, C.E., 1986, Trilobite Taphonomy and Middle Devonian Taphofacies: PALAIOS, v. 1, p. 312, doi:10.2307/3514694.

Speyer, S.E., and Brett, C.E., 1988, Taphofacies models for epeiric sea environments: Middle Paleozoic examples: Palaeogeography, Palaeoclimatology, Palaeoecology, v. 63, p. 225-262, doi:10.1016/0031-0182(88)90098-3.

Speyer, S.E., Brett, C., 1991, Taphonomic controls: background and episodic processes in fossil assemblages preservation. In: Allison, P.A., Briggs, D.E. (eds.). Taphonomy: releasing the data locked in the fóssil record: Topics in Geobiology. New York. Plenum Press, p. 501-545.

Suguio, K.; Martin, L. Flexor, J.., 1992, Paleoshorelines and the sambaquis of Brazil. In: Johnson LL and Stright M (eds) Paleoshorelines and Prehistory: Boca Raton, FL: CRC Press, p. 83-99.

Takesue, R.K., Bacon, C.R., and Thompson, J.K., 2008, Influences of organic matter and calcification rate on trace elements in aragonitic estuarine bivalve shells: Geochimica et Cosmochimica Acta, v. 72, p. 5431-5445, doi:10.1016/j.gca.2008.09.003.

Tanaka, A.P.B., 2010, Sedimentologia, cronologia e dinâmica progradacional das planícies costeiras de Campos Verdes e Ji (Laguna, SC): Universidade de São Paulo, doi:10.11606/D.44.2010.tde-08012011-200134.

Toniolo, T.F., 2014, Uso de vermetídeos fósseis de São Francisco do Sul (SC) como indicadores da variação do nível relativo do mar e para a discussão da circulação costeira no Holoceno: Trabalho de Formatura. IGc-USP.

Toniolo, T.F. 2017. Vermetídeos fósseis como indicadores da variação do nível relativo do mar e possíveis alterações na circulação costeira no Holoceno ao longo do litoral brasileiro. Dissertação de mestrado. IGc-USP.

Ullmann, C. V., Böhm, F., Rickaby, R. E., Wiechert, U., \& Korte, C. (2013). The Giant Pacific Oyster (Crassostrea gigas) as a modern analog for fossil ostreoids: isotopic (Ca, O, C) and elemental (Mg/Ca, $\mathrm{Sr} / \mathrm{Ca}, \mathrm{Mn} / \mathrm{Ca})$ proxies. Geochemistry, Geophysics, Geosystems, 14(10), 4109-4120.

Urey, H.C., 1947, The thermodynamic properties of isotopic substances: Journal of the Chemical Society (Resumed), p. 562, doi:10.1039/jr9470000562.

Villagran, X.S., 2008, Análise de arqueofácies na camada preta do sambaqui Jabuticabeira II: Universidade de São Paulo, doi:10.11606/D.71.2008.tde-14042008-101434.

Villagran, X.S., 2012, Micromorfologia de sítios concheiros da America do Sul: Arqueoestratigrafia e processos de Formação de Sambaquis (Santa Catarina, Brasil) e concheros (Terra do Fogo, Argentina: Universidade de São Paulo, doi:10.11606/T.44.2012.tde-24072013-145242.

Villagran, X.S., 2013, O que sabemos dos grupos construtores de sambaquis? Breve revisão da arqueologia da costa sudeste do Brasil, dos primeiros sambaquis até a chegada da cerâmica Jê: Revista do Museu de Arqueologia e Etnologia, p. 139, doi:10.11606/issn.2448-1750.revmae.2013.107182.

Villagran, X. S. 2014. Experimental Micromorphology on Burnt Shells of Anomalocardia brasiliana (Gmelin 1791)(Bivalvia, Veneridae) and Its Potential for Identification of Combustion Features on Shell-Matrix Sites. Geoarchaeology, 29(5), 389-396. 
Villagran, X. S., \& Giannini, P. C. 2014. Shell mounds as environmental proxies on the southern coast of Brazil. The Holocene, 24(8), 1009-1016.

Villagran, X.S., Deblasis, P., Giannini, P.C.., 2009, Primeiros estúdios micromorfológicos em sambaquis brasileños (Sítio Jabuticabeira II, Estado de Santa Catarina): Intersecciones en Antropología, v. 10, p. 359-364.

Vuille, M., Burns, S. J., Taylor, B. L., Cruz, F. W., Bird, B. W., Abbott, M. B., ... \& Novello, V. F. (2012). A review of the South American monsoon history as recorded in stable isotopic proxies over the past two millennia. Climate of the Past, 8(4), 1309-1321.

Walker, R. 2006, Facies models revisited: Introduction. In: Posamentier, H.W., Walker, R.G. (eds.). Facies models revisited. SEPM Society for Sedimentary Geology, Tulsa, Oklahoma: $527 \mathrm{p}$.

Wanamaker Jr, A. D., Kreutz, K. J., Wilson, T., Borns Jr, H. W., Introne, D. S., \& Feindel, S. (2008). Experimentally determined $\mathrm{Mg} / \mathrm{Ca}$ and $\mathrm{Sr} / \mathrm{Ca}$ ratios in juvenile bivalve calcite for Mytilus edulis: implications for paleotemperature reconstructions. Geo-Marine Letters, 28(5-6), 359-368.

Weber, J. N. (1973). Incorporation of strontium into reef coral skeletal carbonate. Geochimica et Cosmochimica Acta, 37(9), 2173-2190.

Wei, G., Sun, M., Li, X., \& Nie, B. (2000). Mg/Ca, Sr/Ca and U/Ca ratios of a porites coral from Sanya Bay, Hainan Island, South China Sea and their relationships to sea surface temperature. Palaeogeography, Palaeoclimatology, Palaeoecology, 162(1-2), 59-74.

Wiener, C. (1875). Estudos sobre os sambaquis do sul do Brazil (Vol. 1). Museu Nacional do Rio de Janeiro. 